UNIVERSIDADE DE SÃO PAULO

ESCOLA DE ENGENHARIA DE LORENA

MEILY CASSEMIRO SANTOS

Pedagogia de Malba Tahan na formação de professores e no ensino-aprendizagem de Matemática 
MEILY CASSEMIRO SANTOS

\title{
Pedagogia de Malba Tahan na formação de professores e
}

\section{no ensino-aprendizagem de Matemática}

\begin{abstract}
Dissertação apresentada à Escola de Engenharia de Lorena da Universidade de São Paulo para obtenção do título de Mestre em Ciências do Programa de Mestrado Profissional em Projetos Educacionais de Ciências.
\end{abstract}

Orientadora: $\operatorname{Prof}^{a} \operatorname{Dr}^{\mathrm{a}}$ Maria da Rosa Capri.

Edição Reimpressa e Corrigida

Lorena - SP

Jan. 2017 
AUTORIZO A REPRODUÇÃO E DIVULGAÇÃO TOTAL OU PARCIAL DESTE TRABALHO, POR QUALQUER MEIO CONVENCIONAL OU ELETRÔNICO, PARA FINS DE ESTUDO E PESQUISA, DESDE QUE CITADA A FONTE

Ficha catalográfica elaborada pelo Sistema Automatizado da Escola de Engenharia de Lorena, com os dados fornecidos pelo(a) autor(a)

Santos, Meily Cassemiro

Pedagogia de Malba Tahan na formação de

professores e no ensino-aprendizagem de Matemática /

Meily Cassemiro Santos; orientadora Maria da Rosa

Capri - ed. reimp., corr. - Lorena, 2017.

$200 \mathrm{p}$.

Dissertação (Mestrado em Ciências - Programa de Mestrado Profissional em Projetos Educacionais de Ciências) - Escola de Engenharia de Lorena da

Universidade de São Paulo. 2017

Orientadora: Maria da Rosa Capri

1. Educação matemática. 2. Malba tahan. 3. Literatura. 4. Interdisciplinaridade. 5. Interação social. I. Título. II. Capri, Maria da Rosa, orient. 


\section{AGRADECIMENTOS}

\section{Salam Aleikum! (A paz esteja contigo!)}

A Deus, minha MAIOR gratidão, por ter me presenteado com saúde, paciência, força, sabedoria, persistência e compreensão.

Aos meus amados pais, Marilei e Francisco, que me conduziram desde à infância para o mundo dos estudos, dos valores e princípios éticos da vida, que me mostraram o quanto é importante amar e ser inteira naquilo que me proponho a fazer e me entregar com dedicação e responsabilidade ao trabalho.

À memória de minha avó Marcolina, presença amiga e protetora, pelo afeto que me dedicou e que, nostalgicamente, me alimenta.

Ao Marcel, irmão e amigo, pelas palavras de amizade, força e coragem.

À Mara, minha tía e madrinha querida, incentivadora preciosa aos meus estudos acadêmicos e ao meu progresso profissional.

À Irmã Teresa Cristina Domiciano, Diretora do Instituto Nossa Senhora do Carmo, incentivadora constante de práticas educativas inovadoras; sempre disponível para ouvir, aconselhar e tomar as decisões mais certas e viáveis.

A todas as Irmãs Salesianas e todos os colaboradores do Instituto Nossa Senhora do Carmo, pelo apoio diário e pelo entusiasmo em realizar junto comigo as etapas desta pesquisa.

Aos educadores e às educadoras parceiras de caminhada, pais e amados estudantes do Instituto Nossa Senhora do Carmo, que abraçaram a proposta e os desafios para desenvolver projetos interdisciplinares, colaborando assim para a concretização deste trabalho. 
Aos Diretores Executivos da Rede Salesiana de Escolas Irmã Adair Aparecida Sberga e Padre José Adão Rodrigues da Silva, e também aos parceiros de trabalho, que me apoiaram durante o período de conclusão do Mestrado Profissional em Projetos Educacionais de Ciências.

Ao estimado Prof. Darcy Larangeira, que durante as aulas de Inglês e Espanhol me incentivou com entusiasmo e alegria aos estudos e à missão de ensinar e aprender sempre, lembrando-me com sabedoria que "quem tem um amigo, tem um tesouro".

\section{Na academia:}

À estimada Orientadora $\operatorname{Dr}^{\mathrm{a}}$ Prof $^{\mathrm{a}}$ Maria da Rosa Capri e ao estimado Dr. Prof. Angelo Capri Neto, profissionais competentes e criteriosos, seres humanos sensíveis, que proporcionaram equilíbrio, segurança e grandes lições durante o período de desenvolvimento e aplicação do Projeto de Pesquisa.

Aos Professores do Programa de Pós-graduação em Projetos Educacionais de Ciências da Escola de Engenharia de Lorena - EEL/USP pelos ensinamentos e desafios durante o Mestrado Profissional.

À querida Dr ${ }^{\mathrm{a}}$ Prof $^{\mathrm{a}}$ Juraci Conceição de Faria Condé, pelos ricos encontros e partilhas de livros e materiais de pesquisa durante o desenvolvimento e escrita desta dissertação, contribuindo de maneira significativa e valiosa a minha formação.

Aos Professores Membros da Comissão Julgadora que aceitaram o convite e colaboraram com suas observações e apontamentos para a reflexão final desta pesquisa.

Aos colegas do curso de Mestrado Profissional em Projetos Educacionais de Ciências, pelas partilhas durante as leituras, os trabalhos, as preparações das apresentações e os novos laços de amizade em busca de uma educação ideal.

À Diretora Dr $^{\mathrm{a}}$ Prof $^{\mathrm{a}}$ Cristina Cerri, do Centro de Aperfeiçoamento do Ensino da Matemática (CAEM-USP), pelo convite e especial oportunidade de participar da oficina de contação de história para os estudantes de várias escolas públicas e particulares de São Paulo, na "Virada Malba Tahan". 
Aos estudantes do Curso de Matemática do UNISAL-Lorena, pelas partilhas durante a palestra e workshop "A literatura de Malba Tahan como caminho para a alfabetização matemática" no "Encontro de Licenciaturas".

Maktub! (Estava escrito!) 


\section{RESUMO}

SANTOS, M. C. Pedagogia de Malba Tahan na formação de professores e no ensinoaprendizagem de Matemática. 2016. 200 p. Dissertação (Mestrado em Ciências). Escola de Engenharia de Lorena. Universidade de São Paulo, Lorena, 2017.

O objetivo principal deste trabalho foi resgatar, aplicar e avaliar a prática educativa de Júlio César de Mello e Souza, pseudônimo Malba Tahan, e a interdisciplinaridade como um possível caminho para iniciar a compreensão das noções matemáticas na Educação Infantil, superar as dificuldades do ensino de Matemática no $5^{\circ}$ Ano do Ensino Fundamental I e promover a formação continuada interna dos (as) professoras da Educação Infantil e do Ensino Fundamental I do Instituto Nossa Senhora do Carmo (Rede Salesiana de Escolas), localizado na cidade de Guaratinguetá-SP. Tendo como fonte de inspiração a metodologia comunicativo-crítica de investigação, este trabalho conta com observações e registros comunicativos dos participantes como principais instrumentos de coleta de dados; envolve uma análise quantitativa e qualitativa dos dados, em parceria com professores (as) e estudantes das turmas da Educação Infantil e do Ensino Fundamental I da escola investigada. Com os resultados deste estudo é possível avaliar se a aprendizagem da Matemática pode ser desenvolvida por meio da literatura de Malba Tahan resgatando o seu legado literário-pedagógico e articulando-o aos conceitos atuais. Deste modo, tais resultados mostram que as concepções malbatahânicas estabelecem uma mobilização interdisciplinar, no intuito de pensar, elaborar e decidir quais propostas e intervenções podem ser aplicadas a partir de um trabalho interativo e dialógico da Matemática com a Literatura, assim como destas com as demais áreas do saber.

Palavras-chave: Educação Matemática, Malba Tahan, Literatura, Interdisciplinaridade e Interação Social 


\begin{abstract}
SANTOS, M. C. Pedagogy of Malba Tahan in the teacher's graduation at the Mathematics teaching and learning course. 2016. 200 p. Dissertation (Master of Science) - Escola de Engenharia de Lorena, Universidade de São Paulo, Lorena, 2017.

The main objective of this work was to rescue, implement and evaluate the educational practice of Júlio César de Mello e Souza, Malba Tahan pseudonym, and interdisciplinarity as a possible way to start understanding the mathematical concepts in early childhood education, overcoming the difficulties of teaching math in the 5th year of elementary school and promote internal continuing education of teachers from kindergarten and elementary school of the Institute of Our Lady of Mount Carmel (Salesian Schools Network), located in Guaratingueta, Brazil. Taking as inspiration the communicativecritical research methodology, this work has observations and communicative records of the participants main data collection instruments; It involves a quantitative and qualitative analysis, in partnership with teachers and students of classes from kindergarten and elementary school investigated the school. Under the results of this study it is possible to assess whether the learning of mathematics can be developed by Malba Tahan literature rescuing his literary and pedagogical legacy and linking it to current concepts or not. Thus, the results show that malbatahânicas conceptions establish an interdisciplinary mobilization in order to think, prepare and decide which proposals and interventions can be applied from an interactive and dialogical work of mathematics and literature, as well as those with other areas of knowledge.
\end{abstract}

Keywords: Mathematics Education, Malba Tahan, Literature, Interdisciplinarity and Social Interaction 


\section{LISTA DE TABELAS}

Tabela 1 - Resultados em Leitura do $5^{\circ}$ Ano do Ensino Fundamental I.

Tabela 2 - Resultados em Matemática do $5^{\circ}$ Ano do Ensino Fundamental I.

Tabela 3 - Principais Ações Docentes para a Abordagem dos Conteúdos 57 Matemáticos (EI e EFI)

Tabela 4 - Principais Ações Docentes para os Procedimentos de Avaliação (EI e 58 EFI)

Tabela 5 - Principais Ações Docentes para os Procedimentos de Avaliação (EI e 59 EFI) 


\section{LISTA DE QUADROS}

Quadro 1 - Partilha de experiências matemáticas interdisciplinares.

Quadro 2 - Avaliação da equipe docente da EI e do EFI sobre a partilha de experiência 64 matemática interdisciplinar dos $1^{\text {os }}$ anos

Quadro 3 - Avaliação da equipe docente da EI e do EFI sobre a partilha de experiência 65 matemática interdisciplinar do Infantil I (2 anos)

Quadro 4 - Avaliação da equipe docente da EI e do EFI sobre a partilha de experiência 65 matemática interdisciplinar dos $2^{\text {os }}$ anos

Quadro 5 - Avaliação da equipe docente da EI e do EFI sobre a partilha de experiência 66 matemática interdisciplinar do Infantil I (3 anos)

Quadro 6 - Avaliação da equipe docente da EI e do EFI sobre a partilha de experiência 66 matemática interdisciplinar do Infantil II (4 anos)

Quadro 7 - Avaliação da equipe docente da EI e do EFI sobre a partilha de experiência 67 matemática interdisciplinar dos $3^{\text {os }}$ anos

Quadro 8 - Avaliação da equipe docente da EI e do EFI sobre a partilha de experiência 67 matemática interdisciplinar dos $4^{\text {os }}$ anos

Quadro 9 - Avaliação da equipe docente da EI e do EFI sobre a partilha de experiência 68 matemática interdisciplinar do Infantil III (5 anos)

Quadro 10 - Avaliação da equipe docente da EI e do EFI sobre a partilha de experiência 68 matemática interdisciplinar dos $5^{\mathrm{os}}$ anos

Quadro 11 - Plano de Ação da Etapa I: Desafios Matemáticos

Quadro 12 - Eixos e Descritores das Questões da Avaliação Diagnóstica Inicial de 71 Matemática

Quadro 13 - Nomes dos Grupos Interativos definidos pelos estudantes

Quadro 14 - Plano de Ação da Etapa II: Construção do Almanaque Malbatahânico 78

Quadro 15 - Lista dos títulos dos contos de Malba Tahan pesquisados pelos estudantes 80 dos $5^{\mathrm{os}}$ Anos

Quadro 16 - Lista dos nomes das receitas da culinária árabe pesquisadas pelos estudantes

Quadro 17 - Plano de Ação da Etapa III: Jogos Dramáticos com os contos de Malba

Tahan

Quadro 18 - Contos de Malba Tahan sorteados para a dramatização 


\section{LISTA DE SIGLAS}

$\begin{array}{ll}\text { IMT } & \text { Instituto Malba Tahan } \\ \text { MIS } & \text { Museu da Imagem e do Som } \\ \text { EI } & \text { Educação Infantil } \\ \text { EFI } & \text { Ensino Fundamental I } \\ \text { P.M.P. } & \text { Perfeito Mau Professor } \\ \text { USP } & \text { Universidade de São Paulo } \\ \text { CP } & \text { Coordenador Pedagógico } \\ \text { INSC } & \text { Instituto Nossa Senhora do Carmo } \\ \text { SARESP } & \text { Secretaria da Educação do Estado de São Paulo } \\ \text { SAEB } & \text { Sistema Nacional de Avaliação da Educação Básica }\end{array}$




\section{LISTA DE ILUSTRAÇÕES}

Figura 1 - Fluxograma das etapas dos eixos da Pesquisa.

Figura 2 - Gráfico do resultado do tempo de trabalho da equipe docente da EI e do 58 EFI do INSC, em 2015.

Figura 3: Gráfico do número de escolas em que os professores (as) da EI e do EFI 59 do INSC lecionam em 2015.

Figura 4: Gráfico do resultado do tipo de escola onde os professores (as) da EI e do 60 EFI do INSC lecionam em 2015.

Figura 5: Gráfico do resultado da formação acadêmica dos docentes da EI e do EFI 60 do INSC em 2015.

Figura 6: Gráfico do resultado da participação dos (as) docentes da EI e do EFI do 60 INSC em cursos ou palestras em 2015.

Figura 7: Resultado da leitura ou não de revistas de divulgação científica pelos (as) 61 docentes da EI e do EFI do INSC em 2015.

Figura 8: Gráfico do resultado do conhecimento ou não dos Parâmetros Curriculares 61 Nacionais de Matemática dos (as) docentes da EI e do EFI, em 2015.

Figura 9 - As diferentes etapas de uma exploração colaborativa, segundo Thurler 63 (2002, p. 102)

Figura 10 - Gráfico do resultado da Avaliação Diagnóstica Inicial da Turma 1.

Figura 11 - Gráfico do resultado da Avaliação Diagnóstica Inicial da Turma 2.

Figura 12 - Gráfico dos resultados da Avaliação Diagnóstica Inicial de Matemática 73 (Turmas 1 e 2).

Figura 13 - Resolução do desafio "Quadrados Mágicos" do Grupo Interativo I 75 (Turma 1).

Figura 14 - Resolução do desafio "Quadrados Mágicos" do Grupo Interativo III 75 (Turma 2).

Figura 15 - Resolução do desafio matemático "Adivinhação", da estudante 1, do 76 Grupo Interativo I (Turma 1).

Figura 16 - Resultado do desafio matemático “Tangram” da estudante 2 (Turma 1). 76

Figura 17 - Resultado do desafio matemático "Tangram” da estudante 3 (Turma 3). 76

Figura 18 - Resultado do desafio matemático "Jogo do Dez", do Grupo Interativo 78 


\section{III, Turma 1.}

Figuras 19 e 20 - Gráficos dos resultados do jogo "Autódromo" da biografia de 79 Malba Tahan dos Grupos Interativos (Turmas 1 e 2).

Figura 21 - Mensagem e ilustração elaboradas pelo Grupo Interativo I sobre o conto 80 “A glória do sapo" (Turma 1).

Figura 22 - Análise do conto "O homem que calculava", feita pela estudante 4 do 81 Grupo Interativo V, Turma 1.

Figura 23 - Gráfico do resultado da Avaliação Diagnóstica Final da Turma 1. 86

Figura 24 - Gráfico do resultado da Avaliação Diagnóstica Final da Turma 2. 86

Figura 25 - Gráfico dos resultados da Avaliação Diagnóstica Final de Matemática 87 (Turmas 1 e 2). 


\section{SUMÁRIO}

1 INTRODUÇÃO 15

Contextualização das tendências atuais no ensino da Matemática 15

2 MALBA TAHAN 21

2.1 A prática educativa de Júlio César de Melo e Souza Malba Tahan 21

2.2 Contos e artigos de Malba Tahan: a literatura como caminho para a 23 alfabetização matemática

3 INTERDISCIPLINARIDADE 28

3.1 Conceitos, Fundamentos e Princípios da prática docente interdisciplinar 28

3.2 Pedagogia Malbatahânica: o encontro da Matemática com as outras áreas do 35 saber

4 DESAFIOS DA FORMAÇÃO E ORIENTAÇÃO PEDAGÓGICA DE 37 PROFESSORES NA ESCOLA

4.1 Formação continuada: um projeto de vida 37

4.2 Os desafios do Coordenador Pedagógico como gestor de formação 42

4.3 Malba Tahan e a formação de um Bom Professor: mudam os tempos, mudam 44 as exigências para ser um profissional docente competente?

5 METODOLOGIA 50

5.1 Circunstâncias que originaram a pesquisa 50

5.2 Eixos da pesquisa 51

6 ANÁLISE E DISCUSSÃO DOS RESULTADOS 55

6.1 A dinâmica e a organização dos dados da pesquisa 55

6.2 Partilhas de experiências interdisciplinares com os (as) Professores (as) da EI 55 e do EFI: o desafio de contextualizar a Matemática

6.3 Etapas do trabalho com os estudantes dos $5^{\text {os }}$ Anos: analisando o processo $\quad 69$

6.4 Apreciação das vivências interdisciplinares: Matemática, Língua Portuguesa, 87 Arte, Ciências, História e Geografia

7 REFLEXÕES FINAIS

$\begin{array}{ll}\text { REFERENCIAS } & 91\end{array}$

$\begin{array}{ll}\text { APÊNDICES } & 99\end{array}$

$\begin{array}{ll}\text { ANEXOS } & 107\end{array}$ 


\section{INTRODUÇÃO}

\section{Contextualização das tendências atuais no ensino da Matemática}

O conhecimento sobre como as crianças aprendem conceitos matemáticos é cada vez mais amplo. Muitas pesquisas sobre a didática da disciplina, aos poucos, chegam às salas de aula e começam a difundir uma nova maneira de ensinar. O que antes era considerado erro do aprendiz ou falta de conhecimento do conteúdo agora se revela como a expressão de diferentes formas de raciocinar sobre um problema, que devem ser compreendidas e levadas em consideração pelo educador no planejamento (CAVALCANTI, 2001, p. 126) e nas intervenções (FONSECA, 2002, p.18).

Uma breve análise das tendências atuais no ensino da Matemática mostra que, na última década, foram muitas as críticas contra a forma como a escola vem trabalhando os conteúdos escolares. Resnick ${ }^{1}$ (1987, p.15 apud MOYSÉS, 2012, p.59) explica o fenômeno do "encasulamento" ou "encapsulamento" da escola. Trata-se do extremo isolamento que aumenta a cada dia na escola em relação ao mundo que a rodeia. Um dos principais desafios atuais é exatamente este: dar continuidade entre o que se aprende na escola e o conhecimento que existe fora dela, construindo uma ponte entre a escola e a vida. A constatação de que a Matemática raramente é ensinada da forma como é praticada tem instigado estudiosos a repensar esse ensino.

Atuando como Orientadora Pedagógica, durante os atendimentos e orientações aos professores e aos pais quanto ao acompanhamento dos estudos e da aprendizagem dos estudantes, observei que a dificuldade em compreender e gostar de aprender a Matemática não é somente de quem aprende, mas também de quem ensina ou quem auxilia nos estudos, sejam os (as) professores ou as famílias dos alunos. Consequentemente, muitas vezes ocorre um conflito na maneira como os conceitos foram aprendidos pelos pais quando estavam no Ensino Fundamental I e como seus filhos aprendem hoje. A metodologia mais comum era a tradicional, ou seja, a repetição de algoritmos, cujo foco era dominar regras da aritmética, da álgebra e da geometria. A estratégia de ensino utilizada para ensinar eram as aulas expositivas sobre conceitos e fórmulas, com os alunos copiando e fazendo exercícios para a fixação. Aulas em que se expõem conceitos, fórmulas

\footnotetext{
${ }^{1}$ RESNICK, Lauren. “Learning in school and out”. Educational Researcher no 9. 1987, vol. 19, pp. 3-20.
} 
e regras e depois é exigida a repetição de exercícios, tão usadas até hoje, têm origem no começo do século 20. Porém, o trabalho centrado exclusivamente na proposição destes métodos revela que eles não são a melhor opção para aprender e pensar Matemática (DINIZ, 2001, p.100). Tais procedimentos clássicos podem ser utilizados desde que tenham coerência com os objetivos do planejamento e estejam acompanhados de tempo para a reflexão e a discussão em grupo.

Em reuniões pedagógicas, as professoras da escola parceira da aplicação desta pesquisa, relatam as dificuldades dos estudantes nos estudos da Matemática, a falta de interesse e de responsabilidade para as crianças cumprirem as tarefas, assim como a dificuldade do acompanhamento dos pais e responsáveis neste processo de aprendizagem.

Em contrapartida, aos poucos aparecem em programas de formação continuada para professores, maneiras eficientes de ensino da Matemática, cujo foco é a construção de conceitos e estratégias para resolver problemas. As escolas e os professores que propõem esta metodologia organizam Grupos Interativos, cuja dinâmica promove e possibilita o desenvolvimento da Aprendizagem Dialógica (RODRIGUES, 2010, p. 69). Assim, com base no diálogo igualitário, os estudantes aprendem a se ajudar, a compartilhar esforços, a explicar o que aprenderam de maneira mais efetiva, a discutir assuntos e a serem mais solidários entre si. A prática de trabalho com Grupos Interativos é um modo dinâmico de organizar os estudantes no espaço da aprendizagem, pois propõe a formação de grupos heterogêneos, seja no rendimento escolar, no gênero, na etnia, etc. Assim, esta dinâmica também permite trabalhar valores, como solidariedade e respeito, e a desenvolver habilidades sociais, como o trabalho em equipe, a autoestima e também as habilidades comunicativas. (RODRIGUES, 2010, p.72). Pelo fato do grupo ser heterogêneo no rendimento escolar, uma explicação sobre determinado assunto que um educando faz para outro colega do grupo pode ser muito mais clara e compreensível do que a explicação da professora ou da mediadora da turma, porque a linguagem entre eles é mais próxima e pela sua experiência de aprendizagem ser recente (GARCÍA, 2004, p.230). Desta forma, nota-se que novas formas de ensinar a Matemática são apontadas por pesquisadores atuais e pautadas, principalmente, nas atividades em grupo, reconhecendo o papel da interação na construção do conhecimento matemático.

A partir deste contexto a temática deste trabalho tem como objetivo geral resgatar, aplicar e avaliar as Recreações Matemáticas de Júlio César de Mello e Souza Malba Tahan 
e a interdisciplinaridade como uma proposta educativa para iniciar a compreensão das noções matemáticas na Educação Infantil e superar as dificuldades do ensino de Matemática no Ensino Fundamental I do Instituto Nossa Senhora do Carmo (Guaratinguetá-SP), a partir de Grupos Interativos. Os objetivos específicos desta pesquisa são:

- Promover encontros com as professoras da escola durante as reuniões pedagógicas, propondo o planejamento de projetos interdisciplinares que pudessem responder à ação didática e metodológica proposta por Malba Tahan em suas obras;

- Discutir como os processos de interação propiciados por meio de Grupos Interativos ocorrem e de que forma contribuem para a partilha e construção de conhecimentos, sob a ótica dos (das) professores (as) e dos estudantes;

- Despertar nos estudantes o desejo de aprender uma matemática que transcende os limites do algebrismo, estimulando a leitura, a reflexão e o envolvimento dos educandos com as histórias e a exploração de conteúdos matemáticos subjacentes a elas, realizados de forma dialógica entre pesquisadora, professores (as) e estudantes.

Além destes objetivos e do contexto apresentado inicialmente, também é necessário considerar os indicadores de desempenho escolar dos 50 educandos do Instituto Nossa Senhora do Carmo, obtidos na Jornada de Avaliação 2013, que permitiram a apresentação de uma síntese das observações elaboradas pela AVALIA (Sistema de Avaliação com iniciativa da Associação Nacional de Educação Católica do Brasil) aos resultados de desempenho nas competências cognitivas, juntamente à interpretação pedagógica das etapas de aprendizagem. Os dados estão apresentados nas Tabelas 1 e 2.

Tabela 1 - Resultados em Leitura do $5^{\circ}$ ano do Ensino Fundamental I

\begin{tabular}{cccccc}
\hline & \multicolumn{5}{c}{ Distribuição percentual de 50 alunos } \\
\hline ETAPAS & $\mathbf{2 0 0 9}$ & $\mathbf{2 0 1 0}$ & $\mathbf{2 0 1 1}$ & $\mathbf{2 0 1 2}$ & $\mathbf{2 0 1 3}$ \\
AVANÇADO & 44 & 11 & 40 & 54 & 67 \\
PROFICIENTE & 32 & 47 & 38 & 41 & 30 \\
BÁSICO & 22 & 34 & 23 & 5 & 2 \\
ABAIXO DO BÁSICO & 2 & 8 & 0 & 0 & 0 \\
\hline
\end{tabular}

Fonte: AVALIA 2013 (Sistema de Avaliação com iniciativa da Associação Nacional de Educação Católica do Brasil). 
Tabela 2 - Resultados em Matemática do $5^{\circ}$ ano do Ensino Fundamental I

\begin{tabular}{cccccc}
\hline & \multicolumn{5}{c}{ Distribuição percentual de 50 alunos } \\
\hline ETAPAS & $\mathbf{2 0 0 9}$ & $\mathbf{2 0 1 0}$ & $\mathbf{2 0 1 1}$ & $\mathbf{2 0 1 2}$ & $\mathbf{2 0 1 3}$ \\
AVANÇADO & 5 & 1 & 5 & 15 & 2 \\
PROFICIENTE & 38 & 29 & 65 & 64 & 63 \\
BÁSICO & 52 & 47 & 30 & 13 & 33 \\
ABAIXO DO BÁSICO & 5 & 22 & 0 & 8 & 2 \\
\hline
\end{tabular}

Fonte: AVALIA 2013 (Sistema de Avaliação com iniciativa da Associação Nacional de Educação Católica do Brasil).

Os estudantes do $5^{\circ}$ ano do Ensino Fundamental que se encontram na etapa 'Avançado' de desenvolvimento da competência matemática demonstram possuir habilidades e domínio de conteúdos que vão além do esperado para o ano de escolarização. Além de mostrarem domínio de conteúdos referentes à Quantidade e Medida, Espaço e Forma e Incerteza, mostram também maior domínio de habilidades das subcompetências mais elevadas, resolvendo itens de conexão e de reflexão, inclusive resolvendo problemas em que se apresenta um conceito novo no item.

Aqueles que se encontram na etapa 'Proficiente' no desenvolvimento da competência matemática demonstram possuir habilidades e domínio de conteúdos esperados para o tempo de escolarização. Em termos de conteúdos, avançam mais nas ideias estruturadoras de Espaço e Forma e Incerteza, uma vez que a ideia Quantidade e Medida já é a mais presente nas etapas mais elementares. Em relação às habilidades, começam a sobressair as que se referem à subcompetência de Reflexão, resolvendo problemas que envolvem conteúdos das diversas ideias estruturadoras, ainda separadamente, mas não apenas problemas diretamente ligados a números e operações, como nos níveis mais elementares.

Os estudantes do $5^{\circ}$ ano do Ensino Fundamental que se encontram na etapa ‘Básico’ estão em processo de desenvolvimento das habilidades e do domínio de conteúdos compatíveis com a escolarização que têm. Aqui, observa-se equilíbrio das tarefas em relação à sua distribuição entre as diversas subcompetências - os alunos realizam algumas tarefas que dizem respeito à subcompetência de Reflexão, resolvendo problemas que envolvem outros conteúdos além das quatro operações fundamentais.

E aqueles que se encontram na etapa 'Abaixo do Básico' no desenvolvimento da competência matemática dominam predominantemente somente habilidades ligadas às subcompetências de Reprodução e Conexão (com maior ênfase na Reprodução), que se referem a ações do tipo reconhecer, identificar, localizar, ordenar, classificar, relacionar e 
associar. Quanto às habilidades da subcompetência de Reflexão, conseguem resolver alguns problemas, em sua maioria os que envolvem as operações fundamentais com números naturais e adição de decimais. Na verdade, resolvem situações simplificadas, muitas vezes ligadas à definição de cada uma das operações. Contudo, dada uma situação contextualizada, dentro ou fora da matemática, identificam a possibilidade do uso de conhecimentos matemáticos para sua solução, organizam-nos, efetuam as operações necessárias e apresentam a solução, que deve ser compatível com o contexto inicial - o que caracteriza uma tarefa da subcompetência de Reflexão. Seu domínio da competência matemática está associado com o esperado para alunos do $3^{\circ}$ ano do Ensino Fundamental. Esses são os alunos que demandam uma ação imediata da escola no sentido de recuperação, oferecendo-lhes atividades que lhes permitam, pelo menos, alcançar a etapa de competência demonstrada pelos estudantes que se encontram no 'Básico'.

O baixo rendimento dos educandos em Matemática na escola parceira é uma realidade não só em âmbito nacional, mas também mundial. Muitas vezes, os aspectos mais interessantes da disciplina, como resolver problemas, discutir ideias, checar informações e ser desafiado, são pouco explorados na escola (SADOVSKY, 2007). Nota-se que a formação aos docentes dos anos iniciais é insuficiente para aprofundar os aspectos mais relevantes, aqueles que possibilitam considerar os conhecimentos anteriores dos alunos, as situações didáticas e os novos saberes a construir. É preciso aumentar a participação das crianças na produção do conhecimento e, para que aprender matemática tenha sentido para elas, o caminho deve passar pela prática reflexiva e pela formação continuada dos docentes.

O foco dessa tendência e de todas as metodologias ativas que colocam o estudante no centro do processo de aprendizagem é apresentar a ele situações-problema para resolver. O docente tem o papel de mediador, ajudando a construir os conceitos e fazendo com que o estudante tenha consciência do que faz quando responde às questões propostas. O discente deve ser capaz não só de refazer o desafio proposto, mas também de ressignificá-lo diante de novas situações, adaptando e transferindo seus conhecimentos para resolver outros problemas.

Diante do contexto apresentado e com o objetivo de encontrar uma forma de contribuir para a efetiva aprendizagem escolar das crianças que frequentam o Instituto Nossa Senhora do Carmo, foi aplicado um trabalho inspirado na prática educativa de Malba Tahan, que já propunha nas décadas de 30 a 60 que o educando fosse o protagonista 
da aprendizagem. Deste modo, pelos aspectos apresentados, justifica-se a relevância desta pesquisa a respeito das interfaces interdisciplinares das obras de Malba Tahan após as leituras basilares, na busca de apresentar também o desenvolvimento da potencialidade do trabalho com Grupos Interativos, por meio da orientação pedagógica de projetos interdisciplinares dos segmentos da Educação Infantil e do Ensino Fundamental I.

Assim, nos três primeiros capítulos apresentam-se os pilares teóricos que sustentam o trabalho. No primeiro capítulo é apresentada a prática educativa de Malba Tahan e seus contos e artigos como caminho para a alfabetização matemática. O segundo capítulo trata dos conceitos, fundamentos e princípios da interdisciplinaridade na prática docente e a pedagogia de Malba Tahan contemplando o encontro da Matemática com as demais áreas do saber. O terceiro capítulo contempla os desafios da formação e orientação pedagógica de professores na escola, a formação continuada como projeto de vida e os desafios do Coordenador Pedagógico como gestor de formação, articulando a concepção de Malba Tahan sobre a formação de um bom professor com as mudanças dos tempos e das exigências para ser um profissional docente competente.

O capítulo quatro apresenta a metodologia da pesquisa e o quinto capítulo mostra a análise e a discussão dos resultados da pesquisa da seguinte maneira: sua dinâmica e organização, as etapas do trabalho com os estudantes, as partilhas de experiências interdisciplinares entre os professores e o desafio de contextualizar a Matemática, e a apreciação das vivências interdisciplinares.

Este estudo apresenta suas últimas considerações nas reflexões finais com relação ao desenvolvimento global da pesquisa. Por fim, ressalta-se que nos anexos estão as cópias dos documentos oficiais que foram utilizados durante o desenvolvimento do trabalho e nos apêndices estão os documentos elaborados pela pesquisadora. 


\section{MALBA TAHAN}

\subsection{A prática educativa de Júlio César de Mello e Souza Malba Tahan}

Júlio César de Mello e Souza, conhecido por Malba Tahan, nasceu em Niterói, Rio de Janeiro, no dia 6 de maio de 1895.

O pseudônimo Malba Tahan, terceira mistificação literária de Júlio César de Mello e Souza, consagrou a carreira do educador-escritor. Ele próprio revelou em depoimento ao MIS (FARIA, 2004, p. 201), como se preparou: "Durante sete anos estudei o Islã, li o Alcorão e o Talmude e cheguei a tomar aulas particulares de árabe com o Dr. Jean Achar. [...] Eu precisei escolher um pseudônimo. Malba é o nome de um oásis e Tahan significa moleiro, aquele que prepara o trigo". Na época, o Prof. Mello e Souza precisou escolher um pseudônimo para suas obras, pois no Brasil os escritores estrangeiros tinham mais chances de publicar livros.

De acordo com as pesquisas de Faria (2014, p. 37), o pseudônimo Malba Tahan foi inspirado no nome da aluna do Prof. Mello e Souza, Maria Zechsuk Tahan. Malba, em árabe, designa da raiz de certa planta pertencente à família das marantáceas (araruta). Acredita-se que tenha existido no Iêmen (Arábia), pequeno oásis denominado Malbher. O pseudônimo incorporou-se à carteira de identidade do educador-escritor com um decreto especial do Presidente Getúlio Vargas e desde 1954 foi assinado em todas as obras literárias.

Oliveira (2007, p.42) observa que ao analisar o acervo do Instituto Malba Tahan (IMT), percebe-se que as atividades docentes do Prof. Mello e Souza na década de 1940 eram repletas de conferências, noite árabes, aulas, projetos educacionais arrojados e atividades sociais em geral (lançamentos de livros, encontros em entidades sociais (Lions, Rotary e outro) e visitas a institutos de portadores de mal de Hansen, causa onde dedicou grande parte de sua vida, escrevendo obras e proferindo mais de 200 palestras e conferências no Brasil, Argentina, Portugal e Espanha. (FARIA, 2014, p. 42)

A prática educativa do Prof. Mello e Souza baseava-se em colocar o educando como principal protagonista da aprendizagem. Além de ser um professor comunicativo e alegre, também era uma pessoa entusiasmada para ensinar a Matemática. As aulas deste professor-escritor eram encantadoras e todos gostavam da disciplina devido à didática que desenvolvia em suas aulas. 
Malba Tahan criticava as aulas monótonas e o "algebrismo" que dificultava a aprendizagem dos números, posicionando-se contra as práticas pedagógicas de sua época. Por isso, planejava diferentes estratégias para que o interesse dos alunos se mantivesse vivo.

Pires $^{2}$ (2005 apud Oliveira 2007, p. 48-49) afirma que a modernização do ensino de Matemática no Brasil tem suas origens nas décadas de 30 e 40 do século XX. A professora aponta Euclides Roxo e Júlio César de Mello e Souza como protagonistas deste período, devido ao fato deles apresentarem propostas inovadoras para o ensino de Matemática:

Júlio César de Mello e Souza ficou conhecido pelo fato de que, em sala de aula, lembrava um ator empenhado em cativar a plateia. Criou uma didática própria e divertida para ensinar Matemática, inventando Malba Tahan, nome fantasia ou pseudônimo, sob o qual assinava suas obras. Júlio César e Malba Tahan formaram uma dupla de criação que produziu 69 livros de contos e 51 de Matemática, com mais de dois milhões de exemplares vendidos. Sua obra mais famosa, O Homem que Calculava, teve trinta e oito edições. Com o seu pseudônimo, Júlio César propunha problemas de Aritmética e Álgebra com a mesma leveza e encanto dos contos das Mil e Uma Noites. Com sua identidade real, foi um professor criativo e ousado, que buscou ir muito além do ensino exclusivamente teórico e expositivo da sua época, do qual era um feroz crítico. "O professor de Matemática em geral é um sádico", acusava. "Ele sente prazer em complicar tudo". (PIRES, 2005, p.21)

Na obra Didática da Matemática, publicada no final da década de 1950 e início de 1960, Malba Tahan divulgou concepções, ideias e perspectivas referentes ao ensino e à aprendizagem da Matemática, em parceria com outros grandes educadores na época, como: Euclides Roxo, Felix Klein, Anísio Teixeira, Boyer, Bento de Jesus Caraça, Poincaré, Raja Gabaglia, Amoroso Costa, Manoel Jairo Bezerra e muitos outros. a Figura do Matemático, o Algebrismo, o Currículo e o Método de Ensino são os principais temas e ideias sobre o ensino da Matemática presentes em Didática da Matemática.

Em especial, o tema Método de Ensino apresenta cinco propostas: o método heurístico, o método do laboratório, o método eclético moderno (com caderno dirigido), os jogos de classe e as recreações matemáticas (história e folclore da Matemática). As suas principais características, as vantagens e as desvantagens são explicadas por Malba Tahan, que busca auxiliar os professores a ensinar de modo mais divertido, curioso e agradável.

\footnotetext{
${ }^{2}$ PIRES, C. C. Educação Matemática na Educação Básica: uma análise das experiências brasileiras. In: Congresso Ibero-Americano de Educação Matemática, V, 2005, Actas. Lisboa: APM, 2005.
} 
Oliveira (2007, p. 137) analisa que nessa mesma obra, o educador matemático explica os elementos importantes sobre os valores da Matemática, organizados em três grupos: valores utilitários, valores educativos e valores culturais.

Segundo Tahan (1961, p.160), o valor utilitário da Matemática é que esta disciplina fornece meios para a resolução de problemas da vida, tem uma finalidade informativa e utilitária. O valor educativo, por sua vez, requer três condições básicas, conforme Tahan (1961, p.163-165): 1) Que a Matemática seja bem ensinada. 2) Que o professor se interesse diretamente pelo estudante. 3) Que as condições pessoais e materiais do aluno sejam favoráveis à aprendizagem. Quanto aos valores culturais da Matemática, Tahan (1961, p. 178-179) sustenta que só a Matemática torna o indivíduo (até um não-matemático) capaz de compreender e debater problemas que surgirem como corolários da complexidade da vida moderna: viagens interplanetárias, energia atômica, química da saúde, distâncias siderais, crises econômicas, etc. Assim, os valores apresentados por Malba Tahan compõem uma sincronia, ou seja, a Matemática como conhecimento.

\subsection{Contos e artigos de Malba Tahan: a literatura como caminho para a alfabetização matemática}

No universo infantil, as histórias assumem papel importante a partir do final do século XVII, quando as crianças recebem, por meio delas, conselhos morais e edificantes. A partir do século XVIII, as crianças começam a ser vistas em suas particularidades, e não mais como miniaturas dos adultos. Essa evolução ficou registrada nas fábulas, contos e outros textos literários que versavam, acima de tudo, sobre modos de ser, agir, pensar e sentir.

A utilização da Língua Materna na forma literária articulada à Matemática é um dos recursos que pode se mostrar eficiente para o processo de ensino-aprendizagem. Em [SMOLE Et Al, p. 2], as autoras citam: “(...) De algum modo a literatura aparece à criança como manifestação do sentir e do saber o que permite a ela inventar, renovar e discordar". Inventar, renovar e discordar não seriam características associadas também com o aprendizado da Matemática? A simples leitura por si só não estabelece resultados para a educação, pois o que se pede de um aluno vai além disso, como a sua capacidade de análise, de interpretação, de pesquisa, de dedução, de lógica, todas comuns a Matemática e a Língua Materna. Assim, é necessário estabelecer um diálogo com os alunos visando captar a diversidade de raciocínio e formas de resoluções da mesma situação por 
indivíduos diferentes, trabalhando em cima da comparação de resultados e/ou procedimentos utilizados pelo grupo. Isso tudo tem o intuito de enriquecer a discussão dos problemas, saindo do pensamento de que é o professor que sempre obtém a resposta certa.

(...) ensinar não é transferir conteúdo a ninguém, assim como aprender não é memorizar o perfil do conteúdo transferido no discurso vertical do professor. Ensinar e aprender tem que ver com o esforço metodicamente crítico do professor de desvelar a compreensão de algo e com o empenho igualmente crítico do aluno de ir entrando como sujeito em aprendizagem, no processo de desvelamento que o professor ou professora deve deflagrar. (FREIRE, 1996, p. 118)

Partindo deste contexto, podemos refletir sobre as razões pelas quais as histórias narradas se tornaram, ao longo das gerações, tão fundamentais para o desenvolvimento psíquico e intelectual dos leitores. Mais do que isso, podemos tentar identificar quais são as habilidades necessárias para que sejam compreendidas e valorizadas e qual é o papel da escola e dos projetos educacionais nessa valorização.

Atualmente, observa-se que muitos professores da educação básica, formados de acordo com a metodologia da matemática moderna (definições, teoremas e exemplos), dirigida para a matemática pura e abstrata, perderam este vínculo com problemas literários e/ou do quotidiano, apresentando um conhecimento matemático muitas vezes sem significado para o aluno. Para Machado (1990) “o que está em jogo não é a possibilidade de transformação de todos em matemáticos profissionais, mas sim a capacidade universal de utilização consciente de um instrumento básico para a representação da realidade, como é a Matemática".

A narrativa trata da ação e da intenção humana. O pensamento narrativo e o pensamento lógico-científico constituem duas modalidades de funcionamento cognitivo, com as quais as pessoas ordenam a experiência e constroem a realidade. Não há, portanto, uma oposição entre literatura e ciência; elas se somam na interpretação do mundo em que se inserem os leitores.

Júlio César de Mello e Souza Malba Tahan (1895-1974), professor de matemática, escritor e conferencista, buscou trazer à luz a interdisciplinaridade presente nas histórias infantis, em plena década de 60, quando o momento educacional brasileiro era fortemente marcado pela disciplinaridade. Para isso, escreveu, ensinou, dialogou, buscou conquistar outros pares para que o ensino de matemática fosse vinculado às outras áreas do saber. 
próprio momento histórico em que estes haviam sido concebidos. Em grande parte de sua obra, especialmente os livros relacionados à didática, metodologia e curiosidades da matemática, a história é a área do saber a que Malba Tahan frequentemente recorre para ensinar matemática. (FARIA, 2004, p.79)

Com o objetivo de oferecer aos estudantes a riqueza e o prazer experimentados na leitura e na contação de histórias, Malba Tahan adotou a literatura como um dos eixos dinamizadores de sua proposta educativa. Se entendermos a escola como lugar privilegiado para a difusão do conhecimento construído pelo homem, e se o conhecimento pode, em certa medida, transformar os alunos em cidadãos, este matemático escolheu a literatura como um caminho viável, sedutor e convidativo para significar e dar consistência ao conhecimento escolar e de mundo, provocando, ao mesmo tempo, a reflexão e o questionamento acerca da realidade dos seres humanos e da vida social.

Smole e Diniz (2001) esclarecem que é comum os professores acreditarem que as dificuldades apresentadas pelos alunos em ler e interpretar um problema ou exercício de matemática estão associadas à pouca habilidade que eles têm para leitura; ou se o aluno tivesse mais fluência na leitura nas aulas de língua materna, ele seria um melhor leitor nas aulas de matemática.

\footnotetext{
Em qualquer área do conhecimento, a leitura deve possibilitar a compreensão de diferentes linguagens, de modo que os alunos adquiram uma certa autonomia no processo de aprender. Em uma situação de aprendizagem significativa, a leitura é reflexiva e exige que o leitor se posicione diante de novas informações, buscando, a partir da leitura, novas compreensões. (SMOLE e DINIZ, 2001, p.69)
}

Podem-se organizar várias atividades cujo uso cuidadoso e contínuo auxiliará os estudantes a tornarem-se leitores autônomos em matemática. Há muitas maneiras de cuidarmos da leitura em aulas de matemática e de variarmos seus objetivos: ler para aprender, ler para obter uma informação, ler para seguir instruções, ler por prazer, ler para comunicar um texto a outras pessoas (SOLÉ, 1998). Ao mesmo tempo em que percebe que os estudantes ganham fluência na leitura de textos diversos, o educador pode propor outras atividades que envolvam textos de problemas. A primeira delas, sem dúvida, é deixar que eles façam sozinhos a leitura das situações propostas. Depois, em dupla, a leitura auxilia os alunos a buscarem um sentido para o texto. Nessa leitura, o professor pode indicar a cada leitor que tente descobrir sobre o que o problema fala, qual é a pergunta, se há palavras desconhecidas, ou ainda explicar o problema para um colega, orientam Smole e Diniz (2001). 
Então, é possível conduzir uma discussão com toda a classe para socializar as leituras, as dúvidas e as compreensões. Não se trata de resolver o problema oralmente, mas de garantir meios para que todos os educandos possam iniciar a resolução do problema sem, pelo menos, ter dúvidas quanto ao significado das palavras que nele aparecem. Também, é possível que o educador proponha aos estudantes que registrem, no caderno ou em um dicionário, as palavras novas que aprenderam, ou aquelas sobre as quais tinham dúvida, para que possam consultar em outras ocasiões quando necessário.

Celina Tenreiro Vieira e Rui Marques Vieira (2013), pesquisadores da Universidade de Aveiro, em Portugal, apresentam a importância da intervenção da escola na promoção da literacia científica e matemática das crianças e jovens:

Uma das primeiras definições do termo numeracia surgiu no relatório Cockcroft (1982 apud Steen ${ }^{3}$ et al., 2001), sob a responsabilidade do governo britânico, sobre o ensino da matemática. No âmbito desse relatório, o termo "numeracia" implica dois atributos. $\mathrm{O}$ primeiro envolve ter à vontade com os números e usar capacidades e atitudes, bem como aplicar conhecimentos matemáticos que permitem a um indivíduo lidar com as exigências práticas da vida quotidiana. $\mathrm{O}$ segundo representa a disposição para valorizar e a aptidão para compreender informação apresentada em termos matemáticos. [...] Usar e envolver-se com a matemática implica não só o usar a matemática para formular, interpretar e resolver problemas numa variedade de contextos, mas também um amplo envolvimento pessoal por meio do comunicar, relacionar, avaliar, apreciar e gostar da matemática. (VIEIRA; VIEIRA, p. 172-174, p. 2013)

Portanto, para aprender Matemática é preciso resolver problemas, ler, escrever, falar e exercitar matemática e, assim, aprender a contextualizá-la. Smole (2015) também abordou o tema “Alfabetização matemática e os processos mentais básicos" em um encontro de formação com educadores e explicou que a alfabetização matemática requer ações pontuais do professor, como: tornar o aluno um leitor e um escritor de textos matemáticos; desenvolver capacidade de analisar, julgar e argumentar; comunicar ideias efetivamente por meio da linguagem matemática e conhecer a linguagem dos símbolos, das representações gráficas e dos termos específicos.

Espera-se, então, que diante destas abordagens e com o trabalho de leitura dos artigos matemáticos e dos contos de Malba Tahan os estudantes tenham autoconfiança e autoconhecimento para que se sintam seguros da própria capacidade de construir

3 STEEN, Lynn Arthur. et al. The case for quantitative literacy. In: STEEN, Lynn Arthur (Ed.). Mathematics and democracy. The case for quantitative literacy. Reston: National Council on Education and the Disciplines, 2001. 
conhecimentos, desenvolvendo a autoestima e a perseverança na busca de soluções para os desafios do dia a dia e da vida. 


\title{
3 INTERDISCIPLINARIDADE
}

\subsection{Conceitos, Fundamentos e Princípios da prática docente interdisciplinar}

Os movimentos de propostas multidisciplinares, pluridisciplinares, interdisciplinares e transdisciplinares tiveram e têm sua importância na construção de novos paradigmas e trouxeram grandes avanços para o conhecimento e para a ciência. Contudo, questiona-se:

- $\quad$ A que ou a quem esta ciência e os avanços científicos continuam servindo?

- A ideia de disciplinarização ainda está dentro da escola, prendendo os professores no modelo de especialização do conhecimento?

- Como a ideia de interdisciplinaridade pode nos ajudar a romper um pouco a visão de fragmentação do conhecimento e estabelecer uma proposta dialógica entre as disciplinas?

Faria (2004) apresenta os alicerces iniciais da interdisciplinaridade:

\begin{abstract}
Historicamente, sabe-se que a ideia de interdisciplinaridade surgiu na Europa, no final dos anos 60, como exigência estudantil de uma nova escola e de uma nova universidade, que articulasse no ensino e na pesquisa o diálogo entre as diversas áreas do saber. [...] A discussão que pairava sobre os acadêmicos do valor do conhecimento específico das ciências e a possibilidade de extrapolar os seus limites foi uma das bandeiras assumidas por Jean Piaget, ao final dos anos 60, nas quais foi sendo gestada, antes mesmo da teoria da interdisciplinaridade, as primeiras concepções de transdisciplinaridade. [...] Entretanto, a nova "desordem" científica, que certamente acarretaria um "caos social" não foi recebida naquele contexto europeu ordenado historicamente pelos parâmetros de um modelo de ciência desenvolvida e acabada - a ciência moderna, estruturada pelas contribuições científicas de Francis Bacon, Galileu, Descartes e Newton e que servia de inspiração e alicerce à filosofia e às demais ciências há mais de cinco séculos. (FARIA, 2004, p. 89)
\end{abstract}

Edgar Morin (2003), sociólogo, antropólogo, filósofo e historiador francês, defende a valorização de um conhecimento não fragmentado, que permita que homens e mulheres enxerguem o mundo e a humanidade de maneira contextualizada, abrangente e completa. Em sua obra "A cabeça bem-feita" o pensador propõe uma reforma no pensamento, uma mudança que transforme radicalmente a maneira de pensar, ensinar e aprender. Essa transformação na maneira de pensar faria com que o aluno entendesse parte de um sistema. 
Mas será que um aluno de hoje conseguiria fazer tamanha abstração? Como o estudante faz a interligação e relaciona o que é ensinado entre as diversas disciplinas?

A partir destas questões e para compreendê-las, Morin (2003) propõe um ensino que rompa com a separação rigorosa entre as disciplinas. É preciso substituir um pensamento que isola e separa por um pensamento que distingue e une. É preciso substituir um pensamento redutor por um pensamento complexo, pois todo conhecimento para ser pertinente deve contextualizar o seu objeto.

[...] o retalhamento das disciplinas torna impossível apreender "o que é tecido junto", isto é, o complexo, segundo o sentido original do termo. Portanto, o desafio da globalidade é também um desafio de complexidade. Existe complexidade, de fato, quando os componentes que constituem um todo (como o econômico, o político, o sociológico, o psicológico, o afetivo, o mitológico) são inseparáveis e existe um tecido interdependente, interativo e inter-retroativo entre as partes e o todo, o todo e as partes. Ora, os desenvolvimentos próprios de nosso século e de nossa era planetária nos confrontam, inevitavelmente e com mais e mais frequência, com os desafios da complexidade. [...] os desenvolvimentos disciplinares das ciências não só trouxeram as vantagens da divisão do trabalho, mas também os inconvenientes da superespecialização, do confinamento e do despedaçamento do saber. Não só produziram o conhecimento e a elucidação, mas também a ignorância e a cegueira. (MORIN, 2003, p. 14-15)

Nota-se que o problema do sistema de ensino vigente está, então, em propor projetos que contemplem uma parte do todo e escolhermos um paradigma que permita diferenciar e ao mesmo tempo relacionar. Ao contrário disto, o paradigma da 'simplificação' que domina o ensino, separa e reduz o que é complexo em simples. Tal ação mutila, inevitavelmente, o conhecimento, separando as disciplinas, separando o homem da natureza e de todos. Segundo o sociólogo, a espantosa variedade de circunstâncias faz progredir as ciências:

Hoje, é preciso tomar consciência desse aspecto, o menos elucidado da história oficial das ciências, que é um pouco como a face obscura da lua. Intelectualmente, as disciplinas são plenamente justificáveis, desde que preservem um campo de visão que reconheça e conceba a existência das ligações e das solidariedades. E mais: só serão plenamente justificáveis se não ocultarem realidades globais. Por exemplo, a noção de homem está fragmentada entre diversas disciplinas das ciências biológicas e entre todas as disciplinas das ciências humanas: a física é estudada por um lado, o cérebro, por outro, e o organismo, por um terceiro, os genes, a cultura etc. Esses múltiplos aspectos de uma realidade humana complexa só podem adquirir sentido se, em vez de ignorarem esta realidade, forem religados a ela. Com certeza não é possível criar uma ciência do homem que anule por si só a complexa multiplicidade do que é humano. O importante é não esquecer que o homem existe e não é uma "pura" ilusão de humanistas pré-científicos. (MORIN, 2004, p. 112-113) 
Assim, o Professor Nilson José Machado (2011), da Faculdade de Educação da USP, explica a partir das concepções de Edgar Morin, que interdisciplinaridade é um fenômeno comum a duas ou mais disciplinas ou campos do conhecimento. Uma proposta interdisciplinar acontece quando os profissionais fazem um encontro com os conhecimentos que possuem, ou seja, trocam o que sabem ou fazem.

A interdisciplinaridade surgiu como um chamado para que as disciplinas não mudassem os seus objetos, mas que houvesse relações mais fortes entre elas. A escola é disciplinar, mas a realidade não é. Exemplo da água, que não é propriedade da Biologia ou de outra disciplina. Por isso é preciso ter uma relação mais forte. (MACHADO, 2011)

Seguindo esta concepção teórica, consideramos que os estudantes vão para a escola para aprender a ler e compreender o mundo. Se a escola é disciplinar, mas a realidade e o mundo não são, é preciso integrar as disciplinas para que um tema específico seja trabalhado em conjunto. Estudar a Matemática para um fim é para um especialista. É necessário, então, relacionar esta disciplina com outras, ensinar a religar para enfrentar os desafios globais e multidimensionais.

Para inserir o trabalho na sala de aula dentro da interdisciplinaridade é necessário pensar nas ações (o modo como se planeja, avalia, escolhe os materiais didáticos, ou seja, como pensa a organização escolar) e no conhecimento como um tecido de significados, uma teia de relações, considerando que aprendemos a relacionar e a construir conceitos por meio das inter-relações.

Fazenda $^{4}$ (1993 apud Faria, 2004, p. 100), estudiosa que contribui desde a década de 80 até os dias atuais com o movimento interdisciplinar, aponta os fundamentos de uma prática docente interdisciplinar a partir de sua tese: "o movimento dialético, a memória, a parceria, a sala de aula interdisciplinar, o respeito e as pesquisas interdisciplinares".

Faria (2004) descreve cada um deles com propriedade, sendo possível destacar os principais aspectos de cada fundamento de uma prática interdisciplinar:

- Movimento dialético: é o exercício do diálogo permanente entre o velho e o novo, entre a teoria e a práxis, entre o que está pesquisando/produzindo e o que já se pesquisou/produziu.

\footnotetext{
${ }^{4}$ FAZENDA, Ivani Catarina Arantes. Interdisciplinaridade: Um projeto em parceria. São Paulo: Loyola, 1991.
} 
- Memória: a memória-registro e a memória vivida favorecem as pesquisas históricas e sociológicas dos problemas e das práticas educacionais.

- Parceria: é a categoria mestra dos trabalhos interdisciplinares e está sutilmente presente na vida dos educadores. Dela derivam duas categorias: a alegria e a cumplicidade vividas na relação de educador/educando e educando/educador. (Fazenda 1993, p. 12-13 apud Faria, 2004, p. 103).

- Sala de aula interdisciplinar: é uma sala onde a produção de parceria com os nossos alunos acontece e nela existem quatro elementos que a identificam: o espaço físico, o tempo de permanência (o horário), a disciplina (aquela específica) e a avaliação (a esperada pela escola).

- Respeito: é vital e deve primar pelo indivíduo e pelo caminho que cada um empreende em busca de sua autonomia.

- Pesquisas Interdisciplinares: pautadas pela ousadia da busca e da transformação, necessitando constantemente do pensar, do questionar, do construir e do intervir.

Tratando-se dos princípios da prática docente interdisciplinar, Fazenda (2001 apud Faria, 2004, p. 105) aborda cinco: humildade, coerência, espera, respeito e desapego.

No debate sobre os desafios à educação a questão ética está a exigir que se aponte alguns princípios fundamentais e muitos pesquisadores, sob diversos enfoques, também se apoiam nesses e em outros elementos que fundamentam uma prática docente de uma pedagogia transgressora e transcendente.

De acordo com Paulo Freire (2000):

Saber que devo respeito à autonomia e à identidade do educando exige de mim uma prática em tudo coerente com este saber. [...] O respeito à autonomia e à dignidade de cada um é um interativo ético e não um favor que podemos ou não conceder uns aos outros. (2000, p. 66-67)

Nessa visão histórica, a racionalidade neoliberal do jogo de mercado, da livre competição, evidencia a força econômica no modo da ação humana, tolhendo toda e qualquer possibilidade de existir uma ética. Segundo Freire (2000, p.36), a prática educativa tem de ser, em si, um testemunho rigoroso de decência e pureza. A partir disso, ele explica que nós somos capazes de comparar, de valorizar, de escolher, de decidir, de intervir, e de romper todas as barreiras que permeiam os nossos caminhos: só somos porque estamos sendo. Estar sendo é a condição entre nós para ser.

Por isso, é impossível pensar os seres humanos longe da ética, quanto mais fora dela. Acaba sendo uma transgressão, é por isso que é preciso transformar a experiência 
educativa para não se tornar apenas um treinamento técnico, onde fundamentalmente o exercício educativo necessita do próprio caráter formador, respeitando a natureza do ser humano, levando à tona a formação moral do educando. Educar é substantivamente formar. Divinizar ou diabolizar a tecnologia, de acordo com Freire (2000, p. 37).

Esta ideia nos direciona para o que a ética apresenta como uma reflexão crítica sobre a moralidade, sobre a dimensão moral do comportamento do homem. A ética procura o fundamento do valor que norteia o comportamento, partindo da historicidade presente nos valores.

A formação de valores, como esclarece Rios (2001, p. 101), acontece quando o indivíduo se relaciona com o mundo, não se mostrando indiferente a ele, mas dando-lhe uma significação. Há diversos tipos de valores: assim, afirmamos que algo é verdadeiro ou falso, bonito ou feio, útil ou inútil, bom ou mau. São desse último tipo aqueles valores que qualificam a conduta. Neste caso, se relacionam costume e valor. Tende-se a qualificar como boa ou correta uma conduta que seja costumeira e a estranhar uma conduta a que não se está acostumado.

Marques (2001, p. 41) traz a definição de Aristóteles para explicar a educação ética, como uma educação que irá ajudar a cultivar nas pessoas características que ajudarão a florescer como adultos onde sejam capazes de viverem bem e se realizarem na vida. Ela ainda ajudará no crescimento, porque não se restringe apenas ao desenvolvimento dos hábitos corretos do agir ou do sentir, mas também do ensinar. Acaba sendo uma questão de praticar o que é o ensino, embora o domínio da razão esteja presente. Marques (2001, p.36) explica que a ética de Aristóteles enfatiza o caráter e a conduta do indivíduo, já a educação ética de Platão segue o intelecto e o raciocínio.

Com aproximações às argumentações de algumas fontes de leituras referidas no decorrer desta subseção, caracteriza-se a seguir outros princípios do fazer pedagógico interdisciplinar:

a) Solidariedade e igualdade: para fazer frente à apropriação privada dos bens materiais e culturais e ao individualismo nas relações sociais. A dinâmica da sociedade de consumo tende a quebrar todos os laços que prendem os homens entre si, fazendo do “organismo social" um campo de batalha, onde um (como entidade exclusivamente individual) lute contra o outro (sempre visto como concorrente) na disputa pela apropriação individual dos objetos de desejo e na realização dos interesses privados. Contra isso, a atividade docente é desafiada à busca de sentido no trabalho coletivo e na repartição das coisas, dos bens culturais e das responsabilidades. 
b) Responsabilidade social: para que a atividade do profissional de educação seja inserida nas dimensões universais das preocupações humanas. Para Freire (2000), o gosto pela docência - embora inicie com um sonho de infância, alimentado pelas expectativas dos adultos com quem se convive - advém, fundamentalmente, da prática da docência. Uma prática acompanhada pelo desejo de transformar o mundo, de torná-lo mais igual, mais solidário; uma prática pedagógica que, embora não sendo uma panaceia, ou seja, um remédio pretensamente eficaz para todos os males físicos e morais, é indispensável para a transformação. Importa que o professor note que o andamento do mundo depende um pouco dele; que sua parcela de contribuição não é sem importância.

c) Otimismo e Esperança: para combater o desânimo, o niilismo e o "pacto da morte". Não se pode enfrentar os impasses da difícil conjuntura sociopolítica e econômica contextual sem a convicção da positividade do mundo e sem uma aposta esperançosa de futuro. Afinal, “os homens não querem morrer”, garante Marques (2001), mas desejam, até o desespero, viver. Isso é bom índice de que é possível caminhar na construção de superações da crise atual.

d) Humildade: moderação para combater, de um lado, a arrogância e, de outro, a sede infinita do consumo. Gadotti (1998) considera a arrogância uma das principais tarefas (ao lado do combate à burocracia) para construir o socialismo democrático, porque, no fim das contas, o comportamento arrogante descamba para a prepotência, para a arbitrariedade e para a violência. A humanidade não pode suprir, nem em uma terça parte, as expectativas da sociedade de consumo. Os desejos consumistas humanos são infindáveis e os recursos naturais têm limites bem restritos. Por sorte, a felicidade não depende tanto do consumo material, mas, sobretudo, das relações humanas e da construção de um universo simbólico apropriado. Além disso, a humildade é importante para o professor na medida em que o conhecimento fica cada vez mais complexo e recorrente, sendo impossível de ser apreendido integralmente. O professor será competente em regiões cada vez mais limitadas do conhecimento; e, se não tiver uma atitude ética adequada, facilmente cairá em desespero frente à infinitude do saber.

e) Dignidade e Autoestima: para fazer frente à banalização a que tem caído a profissão docente, em função dos maus tratos que recebeu dos poderes constituídos e da propaganda depreciativa feita pelos meios de comunicação de massa. O professor é dos principais responsáveis pelo engrandecimento de seu trabalho. O fim da visão do magistério como sacerdócio e sua consequente profissionalização tirou bastante de seu conteúdo mítico, da sua força de convencimento, de seu encanto. O professor enquanto profissional teve sua 
atividade equiparada a outro trabalho qualquer, e sabe-se que a visão de trabalho, na cultura ocidental, não tem nenhuma dimensão poética: trabalho é sofrimento, é dureza; é atividade do homem de segunda categoria. $\mathrm{O}$ trabalho enquanto labor, enquanto dimensão poética, enquanto construção do mundo e do homem precisa ser construído. Sem querer recuperar a visão tradicional do professor-sacerdote (o que seria um ato extemporâneo e sem sentido) é necessário construir a visão positiva e entusiasmante do magistério.

Em contrapartida, embora o estudo dos princípios para uma prática docente interdisciplinar não seja suficiente para fazer um professor virtuoso, o seu propósito é de ordem prática: ajudar este profissional a refletir e a assumir uma postura interdisciplinar. Decorre que a virtude não é inata e que, enquanto as virtudes intelectuais decorrem do ensino, as virtudes do caráter resultam, sobretudo, da habituação, do costume. Sendo a virtude um estado, e não uma capacidade ou uma emoção, e sendo os estados criados pelo hábito, cada um de nós é livre e tem capacidade para se tornar virtuoso.

Rios (1997) afirma que:

Na direção do bem comum, da ampliação do poder de todos como condição de participação na construção coletiva da sociedade e da história, apresenta-se ao educador, como profissional, em meio à crise, a necessidade de responder ao desafio. Ele o fará tanto mais competente quanto mais garantir em seu trabalho, no entrecruzamento das dimensões que o consistem a dimensão utópica. Esperança e caminho. (RIOS, 1997, p.80)

Os princípios interdisciplinares do educador estão em suas ações, na construção de valores, onde o indivíduo possa participar de um contexto, interferindo e relacionando-se uns com os outros. O que é ser um professor com princípios interdisciplinares no contexto da educação hoje? Numa época em que o relativismo ético radical é marcado por uma certa anomia moral, ou seja, ausência generalizada de respeito a normas sociais, a escola e a educação em geral, podem contribuir para ajudar os jovens a encontrarem os caminhos para a vida digna e para a felicidade. Para ser um professor com princípios interdisciplinares no contexto atual é necessário dominar bem os conceitos de sua área, pensando criticamente nos valores efetivos desses conceitos e na criatividade da construção do bem-estar coletivo, não bastando apenas ser criativo.

A filósofa Viviane Mosé (2011) discute o fato de que as escolas falam de ética, escrevem na lousa a palavra ethos com "th" e começam a conversar com as crianças sobre isso. Está no domínio do idealismo platônico, no domínio da representação. Esse processo de abstração do pensamento na escola que privilegia a palavra, se unido a uma escola que 
privilegia a fragmentação e o acúmulo do conhecimento forma os cidadãos passivos que temos hoje. Por isso, não basta se comprometer eticamente, é preciso que o professor verifique o alcance desse compromisso, verifique se ele efetivamente dirige a ação no sentido de uma vida digna e solidária, por meio de princípios interdisciplinares.

Com base em estudos mais atuais, Fazenda (2014, p. 19), esclarece que o desafio que a formação interdisciplinar adquire é a de incrementar, nos próximos anos, sua capacidade de identificar os diferentes tipos de saberes no ato de ensinar, tornando-os como incompletos e sempre insuficientes.

Então, diante das considerações sobre os conceitos, fundamentos e princípios da prática docente interdisciplinar, comprova-se que a ação interdisciplinar é uma intervenção educativa inovadora, conforme as pesquisas de Fazenda (2014, p.19). E inovações educativas acontecem desde sempre, com práticas pedagógicas desenvolvidas por tantos educadores, inclusive por Júlio César de Mello e Souza Malba Tahan, que trabalhou incansavelmente e assumiu uma atitude interdisciplinar para ensinar.

\subsection{Pedagogia malbatahânica: o encontro da Matemática com as outras áreas do saber}

A expressão "pedagogia malbatahânica" foi cunhada por Faria (2004, p. 122) pelo fato do Prof. Mello e Souza registrar com fidelidade e cuidado as técnicas e os procedimentos de ensino que utilizava para ensinar as belezas e os encantos da Matemática.

Malba Tahan tinha uma relação muito próxima com a pesquisa e com o conhecimento, como revela o seu currículo: lecionou várias disciplinas, não somente a Matemática e abordou em seus livros temas diferentes, como: Ensino da Matemática, Literatura Oriental, Pedagogia, Literatura Infanto-Juvenil, Causa Humanitária/Hanseníase e outros temas diversos. Assim, tinha a habilidade de fazer relações entre a Matemática e as demais áreas do saber, não de modo fragmentado, mas entrelaçando a Matemática e a literatura para ensinar e educar.

Meidani (1997, p. 145) explica que Malba Tahan observava a boa expressão escrita de seus alunos, procurava estimular valores como o respeito, a solidariedade e a generosidade entre eles, criava e recriava toda sorte de estratégias. O objetivo principal da pedagogia malbatahânica era garantir que a disciplina de Matemática fosse compreendida e amada pelos estudantes, como o próprio Prof. Mello e Souza amava. 
É inquestionável o caráter interdisciplinar de Júlio César de Mello e Souza Malba Tahan. Faria (2004, p. 126) observa que o Prof. Mello e Souza criou um diálogo constante entre a Matemática e a literatura, para contribuir efetivamente com uma educação melhor e mais significativa, para combater o algebrismo, o ensino tradicional e o rigor que predominavam nos anos 30 .

Esse seu espírito interdisciplinar de diálogo contínuo da matemática com outras áreas do saber, muitas vezes transcende os campos da disciplinaridade, de diálogo apenas com as disciplinas estudadas na educação escolar. Seu olhar interdisciplinar é mais amplo que o da maioria dos professores de sua época e o alcance de seu foco filosófico e teológico transcende os limites da matemática elementar, sabatinada nos quadros negros das salas de aula do Professor Mello e Souza, resguardada no coração daqueles que tiveram a sorte de tê-lo como professor de matemática. (FARIA, 2004, p. 126)

Considerando a valorosa e expressiva prática educativa do Prof. Mello e Souza para desenvolver a pedagogia malbatahânica, Meidani (1997, p.89) e Faria (2014, p. 47) questionam o fato das obras de Malba Tahan serem pouco conhecidas e praticamente inexploradas; propõem com urgência a apresentação e o resgate do legado deste educador matemático aos educadores brasileiros e, principalmente, vale paraibanos. 


\title{
4 DESAFIOS DA FORMAÇÃO E ORIENTAÇÃO PEDAGÓGICA DE PROFESSORES NA ESCOLA
}

\subsection{Formação continuada: um projeto de vida}

\begin{abstract}
O uso do termo "educação continuada" tem a significação fundamental do conceito de que a educação consiste em auxiliar profissionais a participar ativamente do mundo que os cerca, incorporando tal vivência no conjunto dos saberes de sua profissão. (CRISTOV, 1998, p.10)
\end{abstract}

A formação dos educadores vêm sendo, principalmente a partir da década de 90 , alvo de muitas discussões e descontentamentos. Muitas pesquisas têm centralizado as suas investigações procurando encontrar "bons professores", "professores competentes", "professores reflexivos", ou seja, educadores que em sala de aula apresentam um fazer pedagógico coerente com concepções progressistas de educação. Entretanto, as pesquisas têm revelado o quanto a prática pedagógica destes profissionais pode ser ressignificada à luz das novas concepções.

Faz-se necessário pontuar que por muito tempo a formação oficial não teve a preocupação de incentivar a relação entre teoria e prática docente. Inicialmente, contentava-se em "reciclar" o educador, descartando o seu conhecimento real, introduzindo o novo desconectado do velho, oferecendo cursos rápidos e descontextualizados, somadas a palestras e encontros esporádicos superficiais.

Mais tarde, coerente com o momento histórico por qual passava a concepção de educação, contentou-se em "treinar" o educador tendo como eixo central a modelagem de comportamentos, desencadeando ações apenas com finalidades mecânicas. Ao educador era atribuída a tarefa de fazer e não de pensar, impondo-se modelos, receitas, técnicas do fazer pedagógico.

Buscando superar a dinâmica das formações anteriores surgem, na década de 80, novos conceitos de se pensar/fazer tal processo: "aperfeiçoamento" e "capacitação" de educadores. Coerente com tais conceitos, novas decisões foram tomadas e novas ações propostas. Porém, para alguns educadores, tais estratégias de formar ainda não respondem às demandas de uma prática pedagógica transformadora. Ao refletir sobre o verdadeiro sentido da palavra aperfeiçoar chega-se ao tornar perfeito, completar o que estava incompleto. No conceito de capacitação, tornar capaz parece existir, também, uma doutrinação, inculcação de ideias como sendo verdades absolutas que precisam ser, 
simplesmente, aceitas, exercendo uma função curativa, remediadora e imediatista. Será possível completar alguém? Torná-lo perfeito? Capacitá-lo, como se fosse um processo meramente de fora para dentro? Ou será que, agindo de tal forma, está-se negando a raiz do próprio conhecimento que é um processo constante?

Ultrapassando concepções fragmentárias, exclusivas ou polarizadoras de formação, delineia-se outro tipo de formação: "formação permanente" e ou "formação continuada". Estes dois termos podem ser considerados similares, pois pontuam como eixo central a pesquisa em educação. Tal formação é coerente com o movimento social de direitos humanos, buscando educar o povo, como sempre afirmou Paulo Freire (1987), a "ultrapassar a visão fragmentada da realidade", levando as pessoas a superar o individualismo por meio da cooperação, das soluções coletivas, da liberdade de pensamento, tornando-se cidadãos, avançando de uma "consciência ingênua para uma consciência crítica", buscando uma mobilização social que questione o próprio sistema.

Educar/formar nesta nova perspectiva é considerar, conforme defende Nóvoa (1995), os professores a partir de três eixos estratégicos: a pessoa do professor e sua experiência; a profissão e seus saberes, e a escola e seus projetos.

A formação não se constrói por acumulação (de cursos de conhecimento ou de técnicas), mas sim por um trabalho de reflexão crítica sobre práticas e de (re)construção permanente de uma identidade pessoal. Por isso é tão importante investir na pessoa [...] (NÓVOA, 1995, p.25)

Portanto, é preciso respeitar os professores como pessoas, seres incompletos e eternos aprendizes, que a partir de uma formação contextualizada buscam transformar-se, entender o grupo no qual estão inseridos.

O objetivo central de toda formação continuada deveria ser desenvolver o educador pesquisador; não um pesquisador obcecado pela academia ou pela cientificidade, mas um profissional que tem, primeiramente, uma atitude cotidiana de reflexão da sua prática, que busca compreender os processos de aprendizagem e desenvolvimento de seus alunos, que vai construindo autonomia na interpretação da realidade e dos saberes presentes.

Deste modo, não se trata de uma simples aquisição de conhecimentos, mas de uma transformação da própria pessoa envolvendo mecanismos psicológicos mais amplos, e essa interação sujeito-mundo (local onde habito e no qual dou e recebo significações) é que faz aparecerem problemas mais profundos, os quais a simples instrução não consegue resolver. É necessária uma prática transformadora constituída pela teoria e pela ação, formando uma 
proposta pedagógica que não concebe as pessoas como "destinatárias”, mas como sujeitos da própria atividade política.

Abordando a temática da formação de professores numa perspectiva centrada nas dimensões profissionais, Nóvoa (1995) esclarece:

\footnotetext{
Toda a formação encerra um projeto de ação. E de trans-formação. E não há projecto sem ações. As minhas passam pela valorização das pessoas e dos grupos que têm lutado pela inovação no interior das escolas e do sistema educativo. Outras passarão pela tentativa de impor novos dispositivos de controlo e de enquadramento. Os desafios da formação de professores (e da profissão docente) jogam-se neste confronto. (NÓVOA, 1995, p.31)
}

Busca-se, portanto, uma nova competência pedagógica, surgida a partida da reflexão na e sobre a prática, que em um movimento de ação-reflexão-ação, caminha para uma menor dicotomia teoria/prática, entendendo sempre que entre uma determinada teoria que se quer assumir e a prática que se quer ressignificar existe a teoria do sujeito, a qual se constrói a partir das indagações daquilo que se faz.

As ações de desenvolvimento profissional estão muito ligadas à cultura organizacional, a dimensão informal da organização que afeta o seu desenvolvimento. Com efeito, a atividade profissional dos educadores está inserida em uma organização em seus modos de agir e de ser, cujas regras são aprendidas e ao mesmo tempo produzidas por seus membros (direção, coordenação pedagógica, professores, funcionários, alunos e pais). Como se trata de uma organização educativa, em que tudo educa - o edifício escolar, as condições materiais, a conduta de professores e funcionários da secretaria, o nível de limpeza e outros elementos -, as ações de desenvolvimento profissional não podem estar separadas das práticas de gestão e da cultura organizacional.

Tendo como ponto de partida as exigências e os desafios do mercado de trabalho, de âmbito mundial, é de extrema necessidade uma educação em processo contínuo. A formação continuada contribui para a concretização da dignidade do professor que contribui maior valor e reconhece a importância do seu saber, do seu fazer e, principalmente, de ser professor. A profissão vivenciada dessa maneira, portanto, passa a representar para uma grande parcela daqueles que a exercem não só aquilo que gostam de ser e fazer, mas um constante objeto de estudo.

Libâneo defende

A formação continuada é condição para a aprendizagem permanente e o desenvolvimento pessoal, cultural e profissional. É na escola, no contexto de 
trabalho, que os profissionais enfrentam e resolvem problemas [...] com isso, vão promovendo mudanças pessoais e profissionais. (LIBÂNEO, 2001, p.189)

Seguindo esta referência, contemporaneamente, o processo de formação do professor deve representar o oferecimento de condições para um desenvolvimento pessoal e profissional, em termos de aquisição de saberes, que favoreça respostas às necessidades reais colocadas pela ação educativa e, não apenas uma proposta externa de modificação de procedimentos e de atitudes pedagógicas, supondo que por si só possam assegurar a eficácia daqueles que a adotem.

O foco de observação deve partir da mudança da educação do campo exclusivo dos conhecimentos para a própria vida cotidiana. Na medida em que o mundo progride e se torna mais exigente, o professor deve "dominar" uma grande quantidade de conhecimentos que lhe deem condições de participar efetivamente da vida política, cultural e social dos acontecimentos que o cercam. E “dominar" aqui, não se coloca no sentido de "guardar na memória”, mas no mínimo, poder lançar mão de todos os meios possíveis para encontrálos e usá-los de forma adequada, no momento necessário.

O processo de formação, portanto, implica num "continuum", num processo dinâmico em que o aprendiz é educador e o responsável por sua autotransformação, que ocorre paralelamente à transformação da natureza e do mundo atual. A Educação Continuada é uma exigência atual, porque requer competências necessárias para que todo educador retorne ao passado para propor um futuro, reavalie o presente para construir este mesmo futuro. A capacitação do docente não tem ponto final, mas sim pontos de partida que determinam, como a junção da teoria e da prática, a qualidade do processo como um todo.

Tendo-se também como referência Hugo Assmann (2000, p.29), pode-se acrescentar que a educação permanente deve ser uma construção contínua da "pessoa educadora", de seu saber e de suas atitudes, mas principalmente da sua capacidade de saber-mobilizar. Reencantar a educação significa colocar a ênfase numa visão da ação educativa como ensejamento e produção de experiências de aprendizagem.

Isto implica valorizar como conteúdo da formação do professor seu trabalho críticoreflexivo sobre as práticas que realiza e sobre suas experiências compartilhadas. Deste modo, entende-se que a teoria nos fornece pistas de leitura, mas o que o adulto retém está ligado à sua experiência. Mas isso não significa ficar em nível dos saberes individuais, pois a formação passa sempre pela mobilização de vários tipos de saberes: de uma prática reflexiva, de uma teoria especializada e de uma militância pedagógica. Estes são os 
elementos para produzir a profissão do educador acima de tudo, dotando-a de saberes específicos que não são únicos, no sentido de que não compõem um corpo acabado de conhecimentos, pois os problemas da prática profissional não são meramente instrumentais, senão que comportam situações problemáticas, que obrigam decisões num terreno de grande complexidade, incerteza, singularidade e de conflito de valores.

Produzir uma escola como espaço de trabalho e formação implica gestão democrática e práticas curriculares participativas. Isto sugere pensar a formação como redes de (auto) formação continuada, cujo primeiro nível é a formação inicial.

Essas investigações sobre o educador reflexivo, ao se estabelecerem os nexos entre formação e profissão como constituintes dos saberes específicos, bem como as condições em que se realizam, valorizam o trabalho do gestor como sujeito das transformações que se fazem necessárias na escola e na sociedade. O foco de observação deve partir, sobretudo, de algumas ações que não podem ficar distantes do professor: manter-se informado, participar das manifestações e reflexões pedagógicas, questionar e refletir sobre a prática (individualmente e em grupo), participar de reuniões relatando o que se faz e cooperando com os agentes escolares.

Os dilemas que se apresentam atualmente à formação continuada dizem respeito a como promover mudanças nas ideias e nas práticas profissionais e pessoais docentes. Não se pode esquecer que certas dificuldades dos educadores para se tornarem melhores profissionais decorrem de fatores já conhecidos, de modo que as formas de desenvolvimento profissional precisam recair, inicialmente, nos seguintes fatores: percepções, significados e esquemas de ação já consolidados; deslegitimação da autoridade do professor, à sua baixa autoestima, ao despreparo profissional em face desses novos problemas; despreparo profissional associado a uma frágil formação inicial, fazendo-se necessário investir nas situações de trabalho, em maior conhecimento teórico, envolvendo tanto os saberes pedagógicos como os específicos.

É certo que o professor só alcança o sucesso quando trabalha junto, articulado aos profissionais que formam a instituição. E, por isso, temos uma grande responsabilidade nas mãos: formarmo-nos para depois formar. Por isso, a formação técnica e a formação metodológica são complementares, conforme defendia Malba Tahan:

[...] as escolas... devem exigir três coisas na qualificação de um professor:

a) que conheça aquilo que vai ensinar;

b) que saiba mais do que aquilo que vai ensinar;

c) que saiba como ensinar. $O$ professor, sendo antes de tudo um educador, deve agir sob constante impulso idealista. A ação do professor imediatista deforma inteiramente a obra educacional. (TAHAN, 1967, p. 127, 1967) 
Libâneo, Oliveira e Toschi (2003, p. 377-378) alertam que "programas de desenvolvimento profissional precisam começar por lidar do modo possível com esses fatores, como requisito para pôr em prática ações de desenvolvimento pessoal pela autoreflexividade crítica”.

Perrenoud (2000, p.97) também esclarece que "formar um projeto é dizer "Eu", é considerar-se como um ator que tem domínio sobre o mundo, que se reconhece como um forte, que possui direitos e competências para modificar o curso das coisas".

Assim, as exigências do mundo atual deixam claro que a formação continuada do professor é um projeto de vida, um projeto constante e permanente que se desenvolve a partir do aprimoramento dos seus estudos e da sua prática educativa.

\subsection{Os desafios do Coordenador Pedagógico como gestor de formação}

A escolha e a vivência de uma profissão mobilizam desejos, expectativas, experiências, sonhos construídos em tempos e espaços reais e simbólicos, alicerçados na história de vida e nas circunstâncias produzidas no contexto sociocultural. A decisão de assumir a Coordenação Pedagógica representa para alguns a concretização de um ideal, para outros a efetivação do desejo de contribuir na construção de uma educação de qualidade para o outro e para si mesmo, num processo dialógico.

Se perguntássemos a uma criança o que é gestão, ela seguramente diria que "é um gesto grande". Na tentativa de fazer uma associação entre essa possibilidade e o que dizem os adultos, o dicionário Aurélio (2001, p.347) diz que: gestão é o ato de gerir; gerência, administração.

Por outro lado, o termo "gesto", numa das definições encontradas no mesmo dicionário significa a ação, o ato, em geral, brilhante: gesto de generosidade; gesto de nobreza. Considera-se, então, com os olhos e coração de criança e com a responsabilidade de adulto, que gestão, no campo educacional, pode traduzir-se no gerenciamento pautado por princípios e ações generosas de compartilhamento de decisões, comprometido com a emancipação humana.

Em geral, o CP norteia a trajetória da construção de uma cultura organizacional e a formação continuada como projeto de vida de quem tem a função de gerir. Além disso, também assegura a excelência do processo ensino-aprendizagem e seu permanente aprimoramento de acordo com a legislação educacional; garante a qualidade do 
planejamento educacional, verificando os produtos gerados, seu alinhamento às diretrizes, promovendo a melhoria continuada nos processos educacionais; representar a instituição perante pais, alunos e colaboradores, promovendo a integração escola-família e escolacomunidade.

Libâneo (2003, p.183) lista doze atribuições da função da coordenação pedagógica na escola:

1. Responder por todas as atividades pedagógico-didáticas e curriculares da escola e pelo acompanhamento das atividades de sala de aula, visando a níveis satisfatórios de qualidade cognitiva e operativa do processo de ensinoaprendizagem.

2. Supervisionar a elaboração de diagnóstico e projetos para a elaboração do projeto pedagógico curricular da escola e outros planos e projetos.

3. Propor para a discussão, junto ao corpo docente, o projeto pedagógicocurricular da unidade escolar;

4. Orientar a organização curricular e o desenvolvimento do currículo, incluindo a assistência direta aos professores na elaboração dos planos de ensino, escolha de livros didáticos, práticas de avaliação da aprendizagem.

5. Prestar assistência pedagógico-didática direta aos professores, acompanhar e supervisionar suas atividades, tais como: desenvolvimento do plano de ensino, adequação dos conteúdos, desenvolvimento de competências metodológicas, práticas avaliativas, gestão da classe, orientação de aprendizagem, diagnóstico de aprendizagem, etc.

6. Coordenar reuniões pedagógicas e entrevistas com professores visando promover inter-relação horizontal e vertical entre disciplinas, estimular a realização de projetos conjuntos entre os professores, diagnosticar problemas de ensino-aprendizagem e adotar medidas pedagógicas preventivas, adequar conteúdos, metodologias e práticas avaliativas.

7. Organizar as turmas de alunos, designar professores para as turmas, elaborar o horário escolar, planejar e coordenar o Conselho de Classe.

8. Propor e coordenar atividades de formação continuada e de desenvolvimento profissional dos professores.

9. Elaborar e executar programas e atividades com pais e comunidade, especialmente de cunho científico e cultural.

10. Acompanhar o processo de avaliação da aprendizagem (procedimentos, resultados, formas de superação de problemas, etc).

11. Cuidar da avaliação processual do corpo docente.

12. Acompanhar e avaliar o desenvolvimento do plano pedagógico-curricular e dos planos de ensino e outras formas de avaliação institucional. (LIBÂNEO, 2003, p. 183)

Diante de tantas atribuições, o coordenador pedagógico é o profissional, essencialmente, articula e acompanha o diálogo, as relações, os projetos e a formação continuada da comunidade educativa.

Domingues (2014, p.117) esclarece que pensar a formação na escola implica repensar os papéis formativos, e o protagonismo de professores e coordenadores na tomada de decisões relativas ao seu próprio desenvolvimento profissional. 
Ao aproximar a formação do local de trabalho, encurta-se a distância entre a ação docente real e a reflexão sobre essa ação. Isso implica tomar as necessidades da prática como elemento de reflexão para a formação, o que significa que ela se desenvolverá para responder às "ansiedades" formativas de determinado grupo de educadores comprometidos com o trabalho pedagógico num tempo/espaço determinado. (DOMINGUES, 2014, p.117)

Pelo fato do CP assumir muitas atribuições na escola, acrescidas pelas demandas do cotidiano e pela relação com a equipe educativa e famílias, Domingues (2014) aponta três principais desafios para que este profissional promova a formação continuada dentro do ambiente escolar:

- $\quad$ Primeiro desafio: os limites de uma formação circunscrita à escola - o descompasso entre o tempo de trabalho e as atividades a serem desenvolvidas pelo CP.

- Segundo desafio: a formação como um processo introdeterminado - a formação contínua como projeto pessoal, relacionada à disposição interna em estar junto com outros, organizando e participando efetivamente desta formação e às transformações subjetivas produzidas nas concepções, nas ideias, no saber e no fazer docente.

- $\quad$ Terceiro desafio: a articulação entre as necessidades da formação, a cultura escolar e as determinações das políticas públicas - o coordenador deve ser compreendido com um elo entre os docentes e as determinações políticas públicas ou como um articulador das decisões coletivas, visando ao pleno desenvolvimento da atividade pedagógica, em prol da aprendizagem dos alunos e do aprimoramento dos professores.

Diante destes desafios, realizar o trabalho de formação continuada na escola de maneira reflexiva e crítica exige do $\mathrm{CP}$ a consciência dos inúmeros fatores determinantes dessa tarefa e a apropriação de uma posição de liderança, aspecto destacado como atributo da coordenação, o que implica o desafio de construir uma formação sólida, afinada com a complexidade e a diversidade das situações pedagógicas. Entende-se, então, que a formação centrada na escola expõe o CP como gestor desse espaço formativo e o principal responsável pela valorização dos conhecimentos docentes e pela construção do coletivo escolar, situação que só é possível numa perspectiva gestora democrática e participativa.

\subsection{Malba Tahan e a formação de um Bom Professor: mudam os tempos, mudam as exigências para ser um profissional docente competente?}

Meidani (1997), ao dissertar sobre a importância da Matemática para Malba Tahan e sobre a escolha de ser um Bom Professor, nos convida a refletir sobre a seguinte questão: 
melhorar o próprio mundo do que ensinar, cada vez melhor, aos seus alunos a disciplina que acredita ser a sua forma de ver a realidade, por meio da qual encontra alegria e prazer? (MEIDANI, 1997, p. 148)

Malba Tahan defendia que todas as dimensões das habilidades e competências precisam ser desenvolvidas para ser um Bom Professor: a indumentária, a pontualidade, a postura física, o bom humor, o senso de humor, a simpatia, a generosidade, o respeito, o tom de voz, o teor da fala, o amor pela matéria dada, o senso de dever [...]. (Meidani, 1997, p. 148)

Em seu livro "A Arte de ser um Perfeito Mau Professor" (1967, p. 40-41), Tahan busca justificar a importância da formação continuada de um Bom Professor, tendo como referência outros educadores. Defende que o professor precisa estudar para possuir uma cultura sólida e instiga o leitor a pensar sobre sua formação: "Estudar sempre? Eis uma atividade que parece inconcebível para um Perfeito Mau Professor (P.M.P.) [...] O estudo constante da matéria que leciona impõe-se como uma necessidade imperiosa ao professor".

Tahan (1967, p. 107) ainda tece nesta obra que ao contrário do P.M.P., o Bom Professor se preocupa em motivar os alunos, isto é, em despertar neles a menor parcela de interesse pela matéria a ser lecionada.

Em parceria com outros autores nos livros Antologia do Bom Professor (1969), Páginas do Bom Professor (1969) e Roteiro do Bom Professor (1969), Malba Tahan apresenta caminhos para que a formação docente seja constante e permanente, em todas as dimensões: técnica, estética, ética e política-reflexiva. É possível, assim, entender a essência de suas aulas, de suas obras e de sua vida: formar um ser humano melhor.

Então, contextualizando a visão de Malba Tahan para os tempos atuais, perguntase: como é ser um Bom Professor hoje? E a resposta é imediata e unânime: é um desafio interminável, pois além da cobrança que ele mesmo se faz, existem as exigências da sociedade e da instituição ao qual pertence. Subentende-se que para ser um Bom Professor é preciso ter ética, domínio dos conteúdos, estar atualizado e em constante atualização além da formação contínua, conhecer e entender as teorias, atuais ou não, para compreendê-las no que diz respeito ao momento histórico em que foram difundidas, conhecer as evoluções tecnológicas. É preciso também utilizar da psicologia para entender o que se passa com os educandos, relações humanas para tratar com eles, com pais e porque não com a própria instituição, e poderíamos citar aqui mais uma centena de qualidades técnicas que se requer de um educador. Também, não se admite mais um 
educador calado, introvertido, afastado das discussões, das decisões, com medo de revelar a sua identidade.

Hoje, cobra-se de um Bom Professor que ele tenha personalidade, caráter, idoneidade, que ele pense e tenha ideias próprias. Um educador deve saber fazer suas escolhas e defender esta escolha, deve saber dizer e argumentar, mesmo que ele venha a sofrer consequências disto, ele deve se posicionar, ter princípios, ter coragem... E se o Bom Professor alcançar todas estas qualificações, ele ainda poderá ter que suportar a pressão dos colegas, de seus superiores, quando argumentar sobre seus resultados, seus avanços, seus progressos, sejam eles positivos ou não. E que ninguém duvide: esse novo jeito de ensinar, que dá oportunidade a todos os estudantes de aprender, será "a" referência em educação e, mais cedo ou mais tarde, servirá para diferenciar os melhores profissionais e as instituições que merecem destaque. Por um simples motivo: o professor que não se atualizar e não desenvolver competências vai formar pessoas fora do seu tempo. Quais seriam estas competências? Quais são as mudanças na formação contínua do educador de acordo com esta nova linha de educação?

Segundo Terezinha Rios (2001, p. 21), a ação competente vai se definir como uma ação de boa qualidade. A qualidade que se revela no trabalho competente aponta para novas dimensões aí presentes. Nesta visão, é preciso estar atento, pois esta ação de boa qualidade está reduzida, na perspectiva de Qualidade Total, quando queremos dizer que algo é de qualidade quando é bom.

A autora dá continuidade ao conceito e explica que: "a competência pode ser definida como saber fazer bem o que é necessário e desejável no espaço da profissão" (2001, p.23). Porém, sobre esta afirmação, encontra-se um problema: qual "modus faciende" (modo de fazer) deste saber? Como fazer bem a sua atividade docente? O que é fazer bem?

Rios (2001), assim se expressa a esse respeito:

[...] vamos encontrar o termo competência usado frequentemente para designar conceitos: capacidade, saber, habilidade, conjunto de habilidades, especificidade. Também o terma qualidade se apresenta com várias significações. Fala-se da qualidade de programa de computadores, das qualidades de uma atleta, do controle de qualidade de produtos industriais de um projeto educacional" (RIOS, 2001, p. 67)

Para Perrenoud (1998, p. 2008), sociólogo suíço especialista em práticas pedagógicas e instituições de ensino, competência em educação é a faculdade de mobilizar 
um conjunto de recursos cognitivos - como saberes, habilidades e informações - para solucionar com pertinência e eficácia uma série de situações. Ele afirma que uma competência é um saber-mobilizar. Trata-se não de uma técnica ou de mais um saber, mas de uma capacidade de mobilizar um conjunto de recursos.

É necessário reconhecer que os professores não possuem apenas saberes, mas também competências profissionais que não se reduzem ao domínio dos conteúdos a serem ensinados, e aceitar a ideia de que a evolução exige que todos os professores possuam competências antes reservadas aos inovadores ou aqueles que precisavam lidar com públicos difíceis.

Esta questão dos saberes necessários é retratada por Morin (2000, p.13), quando diz que existem sete saberes necessários que a educação do futuro deveria tratar em toda a sociedade e em toda cultura, sem exclusividade nem rejeição, segundo modelos e regras próprias a cada sociedade e a cada cultura.

Os sete saberes necessários abordados por Morin (2000, p. 13) são os seguintes:

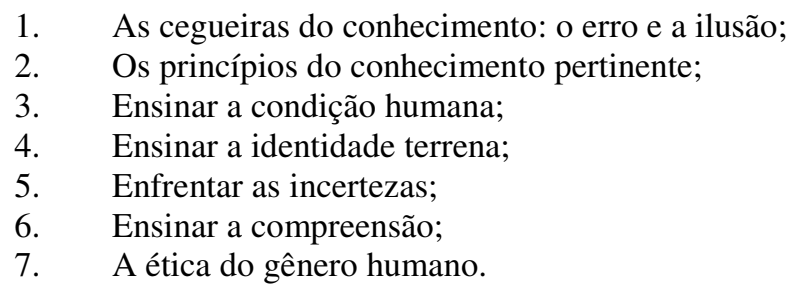

O pensador acredita que estes sete saberes "constituem eixos e, ao mesmo tempo, caminhos que se abrem a todos os que pensam e fazem educação".

Existem hoje diversas competências cruciais na profissão docente. Algumas delas são novas ou adquiriram uma crescente importância nos dias atuais em função das transformações dos sistemas educativos, bem como da profissão e das condições de trabalho dos professores.

Para Perrenoud (2000), essas competências dividem-se em 10 grandes "famílias":

1. Organizar e estimular situações de aprendizagem.

2. Gerar a progressão das aprendizagens.

3. Conceber e fazer com que os dispositivos de diferenciação evoluam.

4. Envolver os alunos em suas aprendizagens e no trabalho.

5. Trabalhar em equipe.

6. Participar da gestão da escola.

7. Informar e envolver os pais.

8. Utilizar as novas tecnologias.

9. Enfrentar os deveres e os dilemas éticos da profissão.

10. Gerar sua própria formação contínua. (PERRENOUD, 2000, p. 14) 
Com a intenção de fazer um paralelo entre a concepção de Malba Tahan sobre o Bom Professor na década de 60 e o profissional docente competente nos dias atuais, indaga-se: será que essas competências são realmente "novas"? Elas definem a "nova profissão" docente? Representam uma ruptura ou são "eternas" no seio da profissão do educador?

Em algumas profissões que dependem totalmente das tecnologias, a renovação das competências é evidente. No entanto, isto não acontece na educação escolar: nem o computador, a multimídia, as lousas digitais, até hoje, fizeram com que a profissão docente mudasse. Desse ponto de vista, a aparente continuidade provoca a ruptura. Se surgissem novas competências, não seria para responder a novas possibilidades técnicas, mas para responder à transformação da visão e das condições de exercício da profissão.

É bastante difícil perceber a novidade, pois as palavras utilizadas para designar as grandes famílias de competências criam uma impressão de familiaridade e, por isso, diversos professores podem, com boa-fé, afirmar que essas competências não lhes são estranhas, que já as possuem, embora nem sempre as dominem bem, nem as apliquem no dia a dia. Por exemplo, que professor confessaria que não sabe organizar e estimular situações de aprendizagem? O ensino nunca foi uma profissão tranquila. Sempre teve de confrontar o outro, sua resistência, sua capacidade, suas ambivalências. Entretanto, devido às suas múltiplas transformações, parece cada vez mais difícil ensinar e, sobretudo, fazer aprender.

Não podemos dissociar as competências da relação com a profissão. Para formar professores mais competentes, aliando uma postura reflexiva e uma forte implicação crítica para o desenvolvimento da sociedade, é necessário desenvolver a profissionalização do professor.

A palavra está na moda, mas a ideia assusta. Provavelmente, todos desejariam beneficiar-se com o patamar de especialização que é associado a uma profissão, ao prestígio, ao poder e a uma boa remuneração. No entanto, os atores hesitam em assumir a parcela de autonomia e responsabilidade que está ligada ao exercício de uma profissão. As autoridades querem conservar seu controle sobre os professores e os estabelecimentos. Por outro lado, estes últimos não desejam prestar contas.

Precisamos entender que para que o profissional docente seja competente, é preciso que se coloque em ação um repertório de recursos: conhecimentos, capacidades cognitivas, relacionais, éticas... Essas competências não se relacionam ao trabalho com os alunos, mas à capacidade de os professores agirem como atores coletivos no sistema e de direcionar o 
movimento rumo à profissionalização e à prática reflexiva, assim como para o domínio das inovações. 


\section{METODOLOGIA}

\section{1 - Circunstâncias que originaram a pesquisa}

Esta pesquisa consistiu no desenvolvimento de dois Eixos Organizacionais. O Eixo 1 contemplou as atividades inspiradas na prática educativa e nos artigos de Malba Tahan, a partir de Grupos Interativos com 46 estudantes dos $5^{\text {os }}$ Anos do EFI do Instituto Nossa Senhora do Carmo (Guaratinguetá-SP). E o Eixo 2 foi desenvolvido por meio das partilhas de experiências matemáticas interdisciplinares com 8 professoras da Educação Infantil e 10 professores (as) do Ensino Fundamental I desta instituição de ensino durante o $1^{\circ}$ Semestre de 2015. Além destes colaboradores, 10 estagiários (as) que cursam Pedagogia também participaram das Reuniões Pedagógicas semanais, momentos em que aconteciam as partilhas de experiências matemáticas interdisciplinares.

Os participantes foram selecionados de maneira não aleatória e informados por escrito e oralmente sobre os objetivos da pesquisa, responsabilidade, métodos empregados e direito a recusar o consentimento. A inclusão dos participantes na amostra foi condicionada ao "Termo de Consentimento Livre e Esclarecido para a Direção do Instituto Nossa Senhora do Carmo" (Anexo A) e "Termo de Consentimento Livre e Esclarecido para Pais e/ou Responsáveis" dos estudantes (Anexo B).

A partir das referências basilares de Vygotsky, Freire, Zabala e Tahan e buscando aprofundamento e avanços na relação com a produção de conhecimento científico, o presente trabalho tem também como orientação as ideias básicas da metodologia comunicativo-crítica elaborada pelo Centro Especial de Investigação em Teorias e Práticas Superadoras de Desigualdades (CREA), da Universidade de Barcelona, e desenvolvida no Brasil, desde 2002, pelo Núcleo de Investigação e Ação Social e Educativa (NIASE), da Universidade Federal de São Carlos. A metodologia comunicativo-crítica é entendida pelos membros do NIASE como caminho metódico de compreensão e de ação no mundo. Caminho metódico de estudo cuidadoso da realidade, buscando mirá-la e admirá-la de diversas perspectivas e, neste caso, caminho feito em diálogo entre pesquisadora e participantes da realidade investigada, para movermo-nos no mundo e transformar a realidade vivida. A teoria dialógica de Paulo Freire e a teoria da ação comunicativa de Habermas são as bases de tal metodologia de pesquisa. 
Habermas ${ }^{5}$ (1984 apud REZENDE PINTO, 1995) afirma que

[...] não é a relação de um sujeito solitário com algo no mundo objetivo que pode ser representado e manipulado, mas a relação intersubjetiva, que sujeitos que falam e atuam, assumem quando buscam o entendimento entre si, sobre algo. Ao fazer isto, os atores comunicativos movem-se por meio de uma linguagem natural, valendo-se de interpretações culturalmente transmitidas e referem-se a algo simultaneamente em um mundo objetivo, em seu mundo social comum e em seu próprio mundo subjetivo. (HABERMAS, 1984, p. 392).

Assim, a proposta de uma ação educativa de cunho interdisciplinar na escola, desenvolvida de acordo com a metodologia comunicativo-crítica, tem como base um processo de interação, em que a pesquisadora e os professores buscam conjuntamente planejar, coordenar, justificar e avaliar ações pedagógicas por meio da partilha de experiências matemáticas. Esta metodologia tem uma potencialidade significativa e foi fonte de inspiração para esta pesquisa, assim como para os estudos organizacionais realizados por educadores que veem a diversidade como trunfo fundamental para o desenvolvimento de projetos interdisciplinares.

\section{2 - Eixos da pesquisa}

\section{Eixo 1: Pesquisadora como Orientadora Pedagógica dos (as) Professores (as) da EI e do EFI.}

Em relação ao eixo da formação continuada da Equipe Docente, a metodologia desenvolveu-se por meio da exploração colaborativa (THURLER, 2002, p. 102) e foi organizada da seguinte maneira:

- Apresentação do Projeto de Pesquisa à Equipe Docente no Planejamento 2015.

- Elaboração de um questionário fechado, cujas respostas são definidas em meio a alternativas previamente estabelecidas, ou seja, questões "objetivas". (AMARO; PÓVOA; MACEDO, 2004/2005) para conhecer o perfil e a prática educativa da equipe docente (Apêndice A);

- Partilhas de experiências matemáticas interdisciplinares: Matemática, Língua Portuguesa, Arte, Ciências, História e Geografia (Anexo R).

A apresentação e apreciação das vivências interdisciplinares ocorreram em dois momentos culminantes:

\footnotetext{
${ }^{5}$ Habermas, J. (1984). The theory of communicative action. Vol 1. Reason and the rationalizalion of society.Boston, Beacon Press.
} 
- Apresentação de um vídeo com as imagens das principais atividades desenvolvidas no decorrer das etapas do Plano de Ação à Inspetora Irmã Helena Gesser, da Inspetoria Santa Catarina de Sena, de São Paulo, à direção, professores e estudantes do EFI do Colégio do Carmo.

- Planejamento e Exposição Malbatahânica (Anexo S) sobre as etapas do projeto durante as Reuniões de Pais do $1^{\circ}$ Trimestre (EFI) e $1^{\circ}$ Semestre (EI).

- Entrega da coletânea de "Poemas Malbatahânicos" (Anexo T), escritos pelos estudantes dos $5^{\text {os }}$ Anos no final da Etapa III do Plano de Ação, à Inspetora Irmã Helena Gesser.

\section{Eixo 2: Pesquisadora como Professora dos estudantes dos $5^{\circ}$ Anos do EFI.}

Aplicaram-se as ideias centrais dos referenciais metodológicos detalhados a seguir em três etapas para favorecer e organizar a sequência didática dos conteúdos estudados em Matemática, Língua Portuguesa e Arte durante o $1^{\circ}$ semestre de 2015:

\section{Etapa I - Desafios Matemáticos (artigos e desafios matemáticos de Malba} Tahan):

- Elaboração da Avaliação Diagnóstica Inicial contemplando os três eixos da Matemática: Números e Operações, Espaço e Forma e Grandezas e Medidas.

- Aplicação da Avaliação Diagnóstica Inicial.

- Apresentação dos fatos da vida de Malba Tahan (dramatização para os estudantes e professores).

- Formação dos Grupos Interativos, atribuição das funções dentro do grupo e distribuição de tarefas.

- Apresentação do artigo “Origem dos Números” (TAHAN, 1961, p. 7 a 11), com dramatização da pesquisadora e proposta do desafio matemático sobre o Eixo Números e Operações.

- Apresentação dos artigos “A origem da Geometria” (TAHAN, 1961, p. 123 a 125) e "Um polígono na poesia" (TAHAN, 1962, p. 57 e 58), com dramatização da pesquisadora e proposta do desafio matemático sobre o Eixo Espaço e Forma.

- Apresentação do artigo "As medidas de tempo na roça e na cidade (TAHAN, 1998, p. 134 a 142), com dramatização da pesquisadora e proposta do desafio matemático sobre o Eixo Grandezas e Medidas. 
- Apresentação de fragmentos dos artigos "O dez nas parlendas infantis" e "Dez, o número universal" (TAHAN, 1998, p. 304 a 313), com dramatização da pesquisadora e proposta do desafio matemático sobre o Eixo Tratamento de Informações.

Etapa II - Almanaque Malbatahânico (construção com os estudantes):

- Apresentação de diferentes tipos de almanaques e pesquisa da vida e obra de Malba Tahan.

- Autódromo da biografia de Malba Tahan.

- Dramatização pela pesquisadora do conto "A glória do sapo”. Elaboração de uma mensagem e uma ilustração do conto por cada grupo interativo.

- Pesquisa e partilha de um conto de Malba Tahan.

- Elaboração de uma mensagem e uma ilustração do conto por cada grupo interativo.

- Pesquisa, partilha de uma receita de culinária árabe e comparação das unidades curiosas na arte Culinária Brasileira, de Malba Tahan.

\section{Etapa III - Jogos Dramáticos (contos de Malba Tahan):}

- Organização para a dramatização de uma história de Malba Tahan: sorteio das histórias e planejamento do cenário, personagens e vestimentas.

- Ensaio para a dramatização de uma história de Malba Tahan, com supervisão da pesquisadora e professores.

- Apresentar para os colegas de turma e para os professores a dramatização de uma história de Malba Tahan.

- Elaboração da Avaliação Diagnóstica Final.

- Aplicação da Avaliação Diagnóstica Final, contemplando os quatro eixos da Matemática: Números e Operações, Espaço e Forma, Grandezas e Medidas e Tratamento da Informação.- Elaboração da avaliação

- Autoavaliação dos estudantes: escritura de poemas.

O fluxograma a seguir (Figura 1) representa o desenvolvimento das etapas dos dois eixos do Projeto de Pesquisa: 
Figura 1 - Fluxograma das etapas dos eixos da Pesquisa.

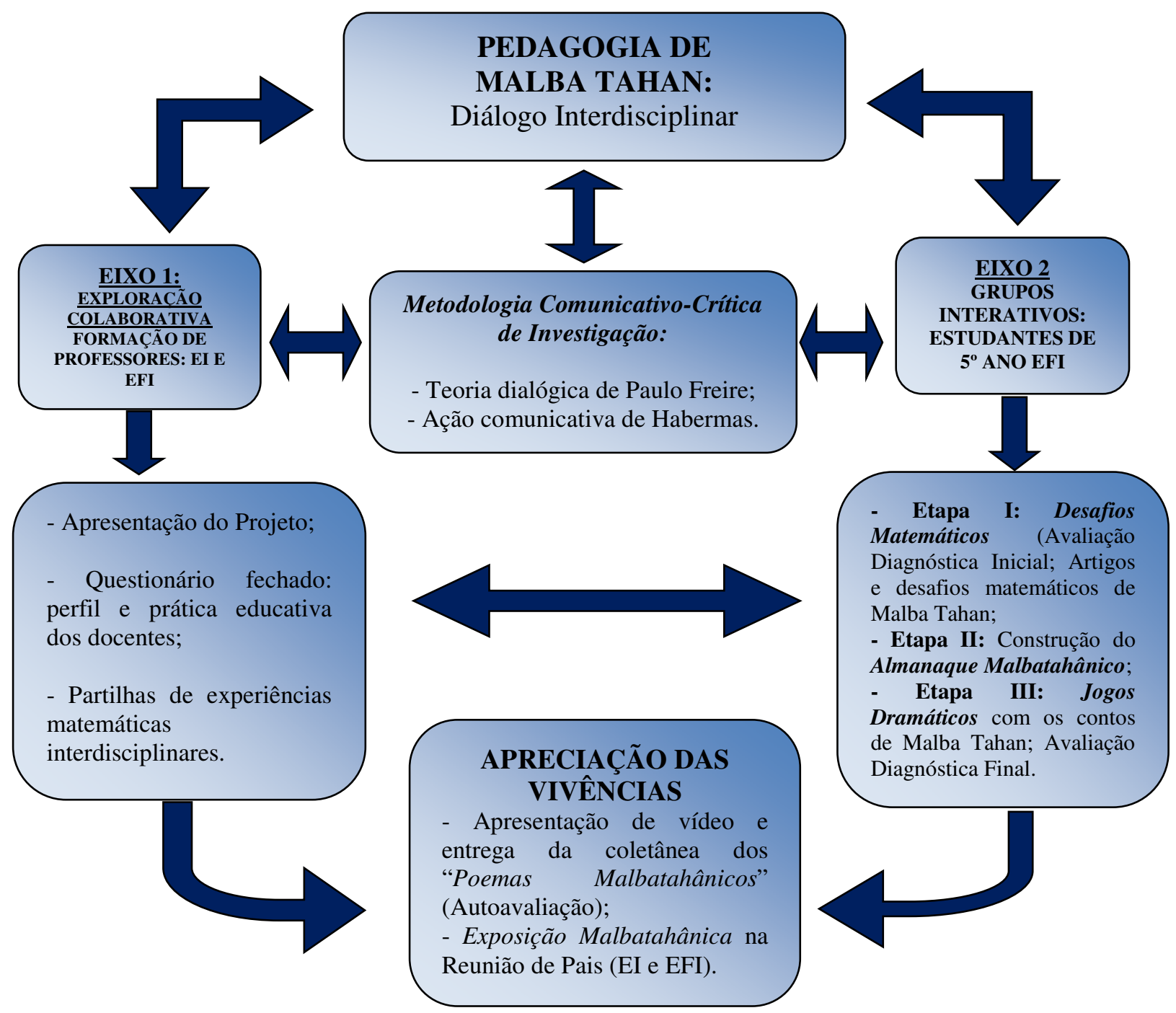

Fonte: autoria própria. 


\section{ANÁLISE E DISCUSSÃO DOS RESULTADOS}

\subsection{A dinâmica e a organização dos dados da pesquisa}

Na tentativa de apresentar os resultados com clareza e sem redundâncias, foi necessário dividir essa análise em dois grandes eixos organizacionais: "Etapas do trabalho com os estudantes dos $5^{\text {os }}$ Anos: analisando o processo" e "Partilhas de experiências interdisciplinares com os (as) Professores (as) da EI e do EFI: o desafio de contextualizar a Matemática". Apesar de estarem divididos para melhor organização deste trabalho, ambos se complementam por tratarem da mesma temática geral. No primeiro trata da apresentação e da avaliação e autoavaliação dos projetos interdisciplinares das professoras da EI e do EFI, da exploração colaborativa por meio da troca de experiências matemáticas e da formação continuada na escola.

No segundo eixo estão ligadas as questões relacionadas à prática educativa de Malba Tahan, à organização dos grupos interativos e da sequência didática das atividades, ao diálogo interdisciplinar, à formação de conceitos matemáticos e interpretação por meio da leitura e da encenação dos contos malbatahânicos.

Foi considerada cada uma dessas questões como uma categoria de análise, a fim de retratar em torno de cada uma as tendências gerais observadas.

\subsection{Partilhas de experiências interdisciplinares com os (as) Professores (as) da EI e do EFI: o desafio de contextualizar a Matemática}

As etapas do Projeto de Pesquisa foram apresentadas à equipe docente na reunião de Planejamento do ano letivo de 2015. Como a pesquisadora atuava como Orientadora Pedagógica no período desta pesquisa, orientando o trabalho pedagógico dos (as) docentes dos segmentos da Educação Infantil e do Ensino Fundamental I da escola parceira, trazia um considerável conhecimento sobre a instituição, sua proposta educativa e seus professores. Não havia analisado, contudo, o perfil docente do ano de 2015, nem conhecia os alunos das turmas dos $5^{\text {os }}$ Anos do Ensino Fundamental I, no qual desenvolveria as três etapas do plano de ação.

Este primeiro momento foi fundamental para a iniciação da parceria entre a pesquisadora e os professores, considerando que produzir e socializar os projetos são 
responsabilidades de toda a equipe educativa. Foram apresentados os objetivos e a justificativa do projeto e explicado que ele seria vivo e mutável, e não algo rígido. Um projeto consistente - e competente - abre a possibilidade do educando se desenvolver numa dimensão em que é possível problematizar, perguntar e buscar respostas que têm uma natureza ética, política, social e científica, levando-o a compreender melhor os conceitos e a superar suas dificuldades.

Elencamos alguns aspectos das nossas estratégias de projetos, que é um termo mais adequado, pois assim abre-se espaço para as possíveis transformações e relações que se dariam ao longo do processo.

- O planejamento de projetos em parcerias;

- A participação e o interesse dos estudantes.

- O diálogo entre as disciplinas a partir da proposta dos livros da Rede Salesiana de Escolas e da prática educativa de Malba Tahan, em correspondência com o Projeto Político Pedagógico Pastoral e com os Planos de Ensino da escola parceira.

Nessa perspectiva, o primeiro encontro com o corpo docente representou o propósito de repensarmos as nossas práticas acompanhado de reformulações e avaliações no sentido de rever os objetivos, as estratégias e as correções de rumos. Tendo como marca a finalidade do processo de formação dos estudantes, os docentes envolvidos puderam desenvolver também a autoformação, mas vinculada à formação do outro.

É necessário destacar que a complexidade desse objeto de estudo exerceu um grande peso no planejamento da forma de organizar os dados para sua análise e discussão. Os conteúdos teóricos se encontraram, seja na interface da prática educativa de Malba Tahan, seja na sequência didática proposta pelos livros da Rede Salesiana de Escolas e Projetos de Leitura Interdisciplinares.

A proposta das partilhas de experiências matemáticas em diálogo com as demais áreas do saber teve o intuito de atender à demanda de formação continuada na escola sobre o tema e oferecer um espaço de partilha, discussão e registro sobre as dificuldades e dúvidas apresentadas pelas professoras quanto à Educação Matemática no dia a dia em sala de aula. As professoras foram orientadas pela pesquisadora que atua como Coordenadora Pedagógica da Educação Infantil e do Ensino Fundamental I da escola parceira para planejar, acompanhar e avaliar todo o caminho percorrido por cada turma. 
Para inaugurar o trabalho e conhecer melhor o perfil e a prática educativa da equipe docente da EI e do EFI do ano letivo de 2015, foi aplicado a 24 educadores, na primeira Reunião Pedagógica, um questionário elaborado pela pesquisadora (Apêndice A), com questões fechadas (AMARO; PÓVOA; MACEDO, 2004-2005).

Com o auxílio das Tabelas 3 a 5 e das Figuras 2 a 8 é possível analisar como é formada a equipe de Professores (as) da EI e do EFI do Instituto Nossa Senhora do Carmo, no ano de 2015, e como eles (as) realizam as atividades para desenvolver as habilidades e competências matemáticas dos estudantes:

Tabela 3 - Principais ações docentes para a abordagem dos conteúdos matemáticos (EI e EFI)

\begin{tabular}{|c|c|c|}
\hline AÇÕES & $\begin{array}{c}\text { PROFESSORES } \\
\text { QUE REALIZAM } \\
\text { ESTAS AÇÕES }\end{array}$ & $(\%)$ \\
\hline 1. Propor exemplos de situações relacionadas ao cotidiano. & 24 & 100 \\
\hline 2. Propor exemplos de situações para fixar procedimento. & 19 & 79 \\
\hline 3. Decorar regras e fórmulas, aplicando-as a situações-problema. & 0 & 0 \\
\hline 4. Propor problemas que envolvem aplicação de fórmulas e algoritmos. & 02 & 08 \\
\hline $\begin{array}{l}\text { 5. Partilhar entre os alunos as diferentes soluções, discutindo com a professora } \\
\text { os processos utilizados. }\end{array}$ & 20 & 83 \\
\hline $\begin{array}{l}\text { 6. Trabalhar com os temas que aparecem em jornais/revistas, discutindo suas } \\
\text { relações com a matemática. }\end{array}$ & 12 & 50 \\
\hline 7. Propor jogos, pesquisas e dramatização de histórias. & 20 & 83 \\
\hline
\end{tabular}

Fonte: Arquivo pessoal.

Nota-se na Tabela 3 que a ação 1 é a mais realizada pela equipe docente para abordar os conteúdos matemáticos, seguida das ações 5, 7 e 2. De acordo com as respostas obtidas, nenhum professor (a) usa a ação 3 para trabalhar a Matemática, talvez porque os livros da Rede Salesiana de Escolas, material utilizado pelos (as) docentes do INSC, priorizem o domínio de competências e habilidades que dependem não de simples memorização, mas de um desenvolvimento progressivo, ao longo dos anos de formação básica. Somente 2 docentes praticam a ação 4 , talvez porque lecionam do $4^{\circ}$ e/ou $5^{\circ}$ Ano. 


\begin{tabular}{lcc}
\hline \multicolumn{1}{c}{ AÇÕES } & $\begin{array}{c}\text { PROFESSORES } \\
\text { QUE REALIZAM ESTAS }\end{array}$ & $(\boldsymbol{\%})$ \\
& AÇÕES & 95 \\
\hline 1. Atividades em equipe. & 23 & 75 \\
2. Atividades individuais. & 18 & 91 \\
3. Interação entre alunos e entre estes e o professor. & 22 & 41 \\
4. Grupos interativos. & 10 & \\
\hline
\end{tabular}

Fonte: Arquivo pessoal.

Das respostas que se referem às ações docentes para a organização da sala de aula, a Tabela 4 mostra que a maioria dos professores (as) realiza a ação 1, seguida da ação 2 , provavelmente pelo fato dos livros da Rede Salesiana de Escolas, utilizados pelos (as) professores (as) do INSC, orientarem estas organizações. Constatou-se que a equipe docente pouco utiliza a ação 4 , talvez por não dominarem de fato a metodologia dos Grupos Interativos, sendo possível um estudo aprofundado para o seu conhecimento durante as orientações da Pesquisadora/Orientadora Pedagógica na elaboração dos projetos para as partilhas de experiências matemáticas entre os (as) professores (as) durante as Reuniões Pedagógicas.

Figura 2 - Gráfico do resultado do tempo de trabalho da equipe docente da EI e do EFI do INSC, em 2015.

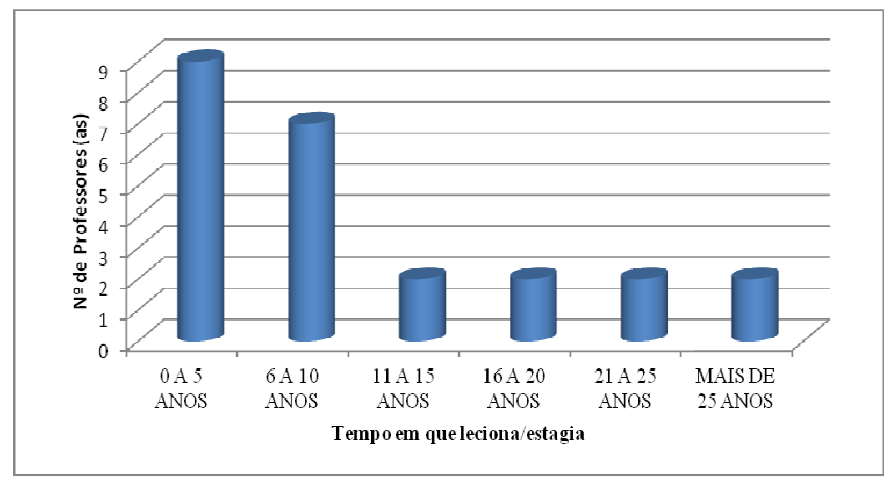

Fonte: Arquivo pessoal.

Com a representação da Figura 2 é possível constatar que 09 docentes estão no início da carreira docente, seguidos de 7 professores que lecionam de 6 a 10 anos. É preciso esclarecer que somente 4 estagiários (as) participaram do questionário. É evidente, então, a necessidade da formação permanente e contínua no ambiente escolar. A proposta da partilha de experiências matemáticas interdisciplinares é um bom momento para que as professoras com mais tempo de vivência em sala de aula contribuam para isto. 
Tabela 5 - Principais ações docentes para os procedimentos de avaliação (EI e EFI)

\begin{tabular}{|c|c|c|}
\hline AÇÕES & $\begin{array}{c}\text { TOTAL DE } \\
\text { PROFESSORES } \\
\text { QUE REALIZAM ESTAS } \\
\text { AÇÕES }\end{array}$ & $(\%)$ \\
\hline 1. Tarefas para casa. & 19 & 79 \\
\hline 2. Trabalhos em grupo/equipe. & 17 & 70 \\
\hline 3. Uso de provas/avaliações; & 11 & 45 \\
\hline 4. Elaboração de portfólios/relatórios. & 15 & 62,5 \\
\hline 5. Desempenho dos alunos em atividades práticas. & 24 & 100 \\
\hline 6. Autoavaliação. & 09 & 37,5 \\
\hline
\end{tabular}

Fonte: Arquivo pessoal.

Quanto às ações docentes para o procedimento de avaliação da EI e do EFI, verificou-se na Tabela 5 que a ação 5 alcançou o maior número de respostas, possivelmente pelo fato de que os (as) professores (as) escrevem relatórios com as observações semanais e mensais sobre o desempenho dos alunos em todas as atividades, inclusive práticas. Contudo, a ação 6 é a menos feita em sala de aula, sendo necessário repensá-la para os próximos planejamentos, pois é um valioso instrumento avaliativo que desenvolve a percepção do estudante sobre si mesmo em relação ao que é capaz de realizar no contexto. Além disso, a autoavaliação possibilita que o estudante apresente para o (a) professor (a) o que ainda não aprendeu e este pode buscar diferentes recursos pedagógicos para valorizar suas dificuldades e os seus erros para promover assim a construção dos conhecimentos matemáticos.

Figura 3: Gráfico do número de escolas em que os professores (as) da EI e do EFI do INSC lecionam em 2015.

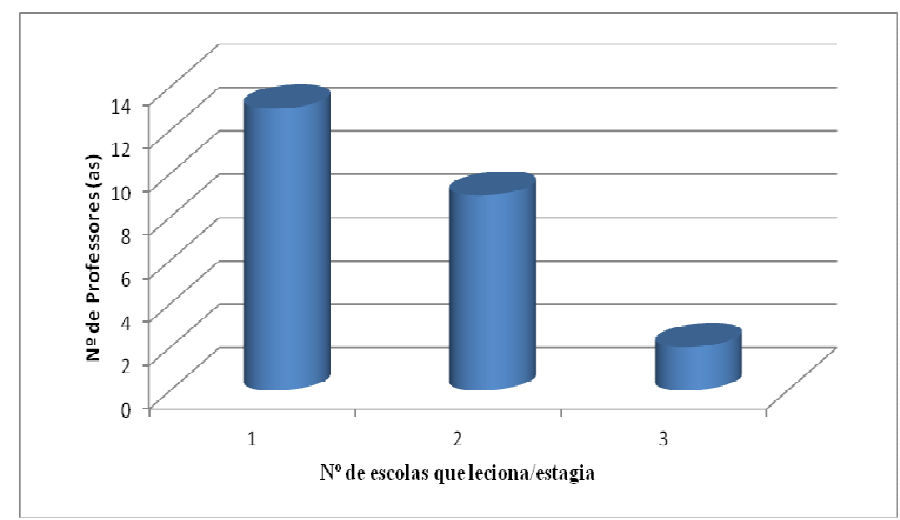

Fonte: Arquivo pessoal.

Nota-se que na Figura 3 a maioria dos docentes dos segmentos da EI e do EFI leciona somente no Colégio do Carmo. Confere-se que 9 trabalham em 2 escolas e somente 2 professores dão aula em 3 escolas em 2015. 
Figura 4: Gráfico do resultado do tipo de escola onde os professores (as) da EI e do EFI do INSC lecionam em 2015.

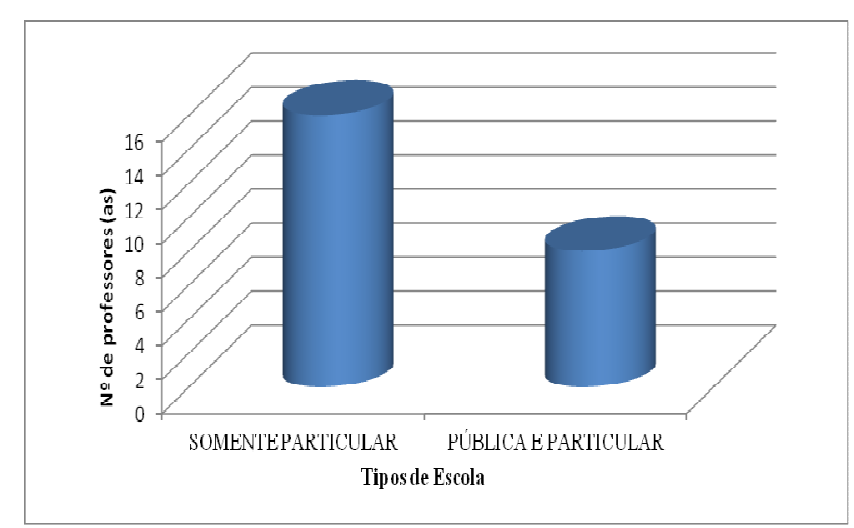

Fonte: Arquivo pessoal.

A Figura 4 mostra que 16 docentes da EI e do EFI do INSC lecionam somente em instituições particulares e 8 em dois tipos de escola: pública e particular.

Figura 5: Gráfico do resultado da formação acadêmica dos docentes da EI e do EFI do INSC em 2015.

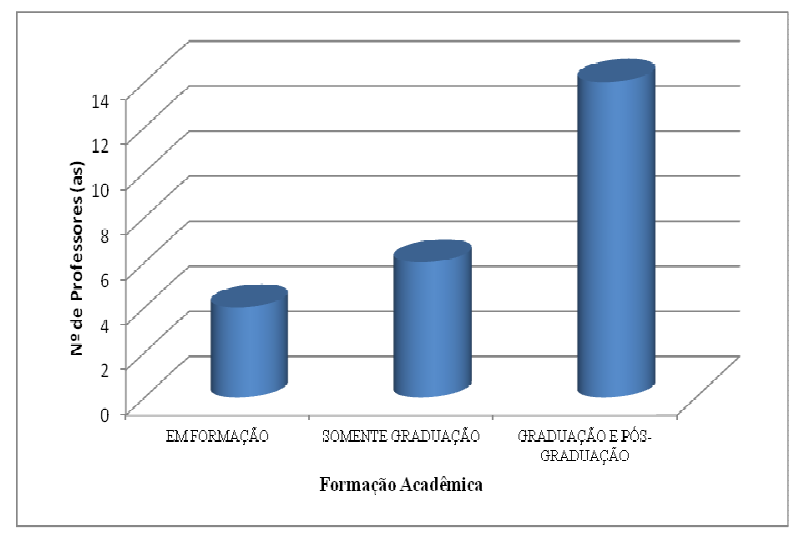

Fonte: Arquivo pessoal.

Em 2015, a Figura 5 mostra que a maioria dos docentes da EI e do EFI do INSC tem graduação em Pedagogia e Pós-Graduação na área de Educação (Especialização). Verificou-se que 6 professores (as) têm graduação em Pedagogia e 4 estão em formação (estagiários (as) que participaram do questionário).

Figura 6: Gráfico do resultado da participação dos (as) docentes da EI e do EFI do INSC em cursos ou palestras em 2015.

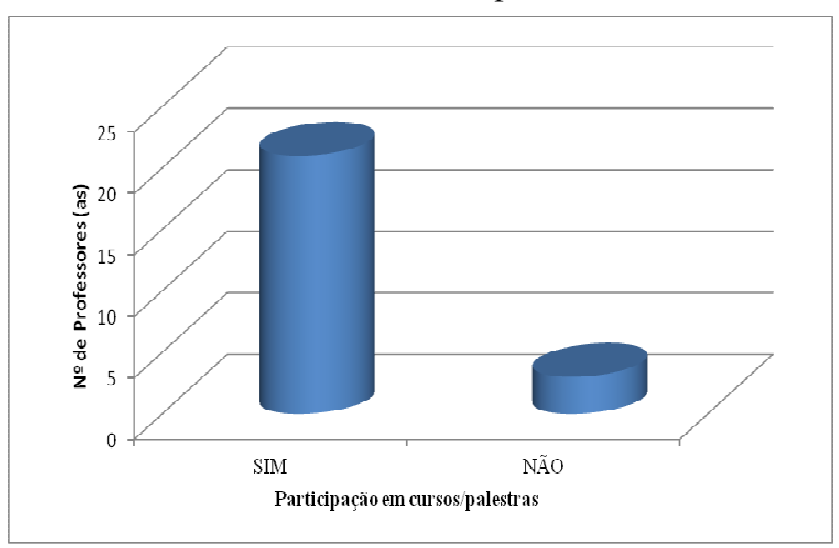

Fonte: Arquivo pessoal. 
A participação dos docentes da EI e do EFI do INSC em cursos e palestras é alta: 21 professores confirmaram isto, segundo a Figura 6.

Figura 7: Resultado da leitura ou não de revistas de divulgação científica pelos (as) docentes da EI e do EFI do INSC em 2015.

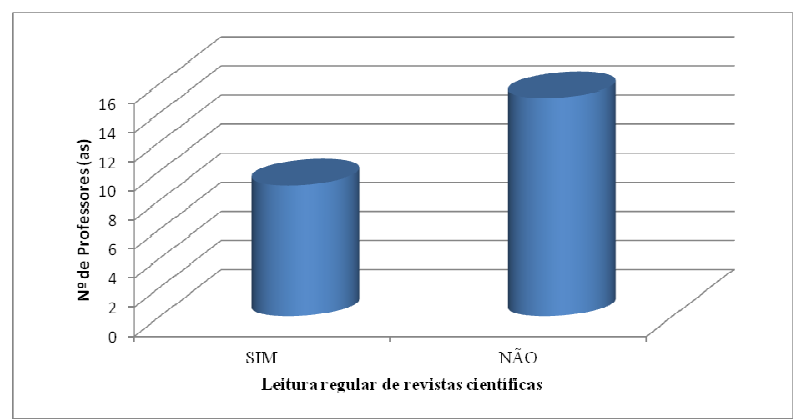

Fonte: Arquivo pessoal.

A Figura 7 alerta que a maioria da equipe docente da EI e do EFI do INSC não tem o hábito de ler regularmente artigos de revistas de divulgação científica em 2015. Este indicador foi um alerta para que a Pesquisadora/Orientadora Pedagógica planejasse momentos formativos articulando a teoria com a prática docente, pois o aprimoramento das ações pedagógicas só é efetivo se os (as) professores (as) têm momentos de formação permanente na escola, individuais e coletivos, realizando a leitura e o estudo de artigos científicos que ampliem a competência e a ação-reflexão-ação.

Figura 8: Gráfico do resultado do conhecimento ou não dos Parâmetros Curriculares Nacionais de Matemática dos (as) docentes da EI e do EFI, em 2015.

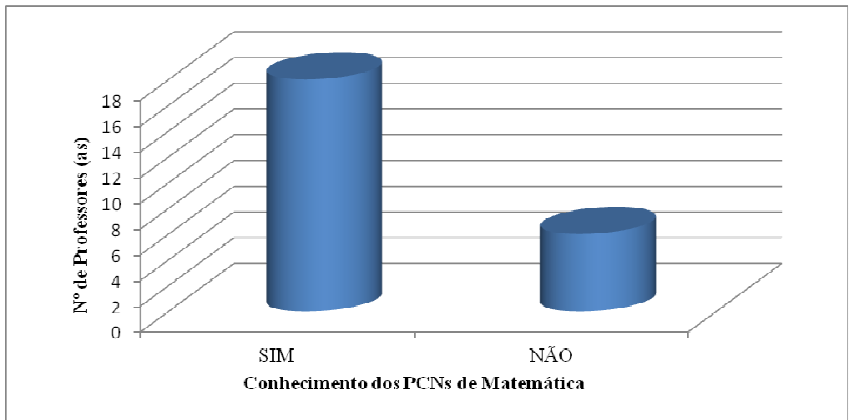

Fonte: Arquivo pessoal.

Por fim, contatou-se na última questão, apresentada na Figura 8, que 18 educadores da EI e do EFI têm conhecimento dos Parâmetros Curriculares Nacionais de Matemática. Alguns observaram na pesquisa que utilizam este documento para elaborar o Plano de Ensino anual e planejar suas aulas.

Após conhecer um pouco o perfil e a prática educativa da equipe docente da EI e do EFI da escola parceira por meio do questionário aplicado, foram dadas importantes 
orientações para organizar melhor os momentos de partilha de experiências matemáticas interdisciplinares. Deste modo, fizemos os seguintes combinados:

- As partilhas aconteceriam nas Reuniões Pedagógicas, uma vez por semana, com duração de 1 hora e 15 minutos;

- Planejar em parceria com a sua companheira de ano/turma a apresentação a partir das práticas desenvolvidas em sala de aula, contemplando a proposta do livro de Matemática da Rede Salesiana de Escolas, do Projeto de Leitura e/ou da disciplina específica da qual é responsável;

- Elaborar uma pauta com os pontos principais do que foi explorado com os estudantes e enviar com antecedência para a Coordenadora Pedagógica verificar e encaminhar para o setor de xerox;

- Preparar a apresentação em Power Point/Prezi, com duração de 50 minutos;

- A partilha de experiência deveria ter a sequência de apresentação a seguir:

1.

Tema;

2.

Objetivo Geral e Objetivos Específicos;

3.

Tempo/Período;

4.

Recursos/Materiais;

5.

Estratégias/Desenvolvimento;

6.

Registros Fotográficos/Vídeos;

7.

Avaliação Crítica da proposta;

8.

Autoavaliação.

No Quadro 1 consta como foi realizada a organização da Partilha de Experiências Matemáticas Interdisciplinares:

Quadro 1 - Partilha de experiências matemáticas interdisciplinares

\begin{tabular}{|c|c|c|}
\hline Segmentos & Anos/Turmas & Temas \\
\hline Ensino Fundamental I & $1^{\text {os }}$ Anos & $\begin{array}{l}\text { "A Matemática de Malba Tahan e a da Rede } \\
\text { Salesiana de Escolas" }\end{array}$ \\
\hline Educação Infantil & Infantil I (2 anos) & "Classificação de Objetos" \\
\hline Ensino Fundamental I & $2^{\text {os }}$ Anos & "Trabalhando com quantidades" \\
\hline Educação Infantil & Infantil I (3 anos) & "Classificação e seriação de Blocos Lógicos" \\
\hline Ensino Fundamental I & $3^{\text {os }}$ Anos & $\begin{array}{l}\text { "Observando e criando sob os diferentes pontos } \\
\text { de vista dos sólidos geométricos" }\end{array}$ \\
\hline Educação Infantil & Infantil II (4 anos) & $\begin{array}{l}\text { "Interdisciplinaridade } \\
\text { Caleidoscópio e Projeto de Leitura" }\end{array}$ \\
\hline Ensino Fundamental I & $4^{\text {os }}$ Anos & "Trabalhando com Grandezas e Medidas" \\
\hline Educação Infantil & Infantil III (5 anos) & "Trilha das Formas" \\
\hline Ensino Fundamental I & $5^{\text {os }}$ Anos & $\begin{array}{l}\text { "A literatura abrindo caminhos para o } \\
\text { entendimento matemático" }\end{array}$ \\
\hline
\end{tabular}

Fonte: Arquivo pessoal. 
Foram considerados três aspectos para o desenvolvimento das Reuniões Pedagógicas em que aconteceram as Partilhas de Experiências Interdisciplinares: Investigação Permanente (realização de novas atividades), de Formação Permanente (espaço de diálogo igualitário com os agentes educativos sobre a aprendizagem dos alunos) e de Avaliação Permanente (instrumento de melhoria dos processos de participação e de aprendizagem do trabalho docente).

As etapas da "Exploração Colaborativa" de Thurler (2002, p.102) foram utilizadas como referência para o desenvolvimento do trabalho. A autora explica que o grupo de educadores precisa estar disposto a trabalhar junto sobre uma problemática comum, relacionada a uma atividade pedagógica específica. No caso, o desafio era contextualizar a Matemática em sala de aula. A Figura 9 esboça as etapas desta conduta:

Figura 9 - As diferentes etapas de uma exploração colaborativa, segundo Thurler (2002, p. 102)

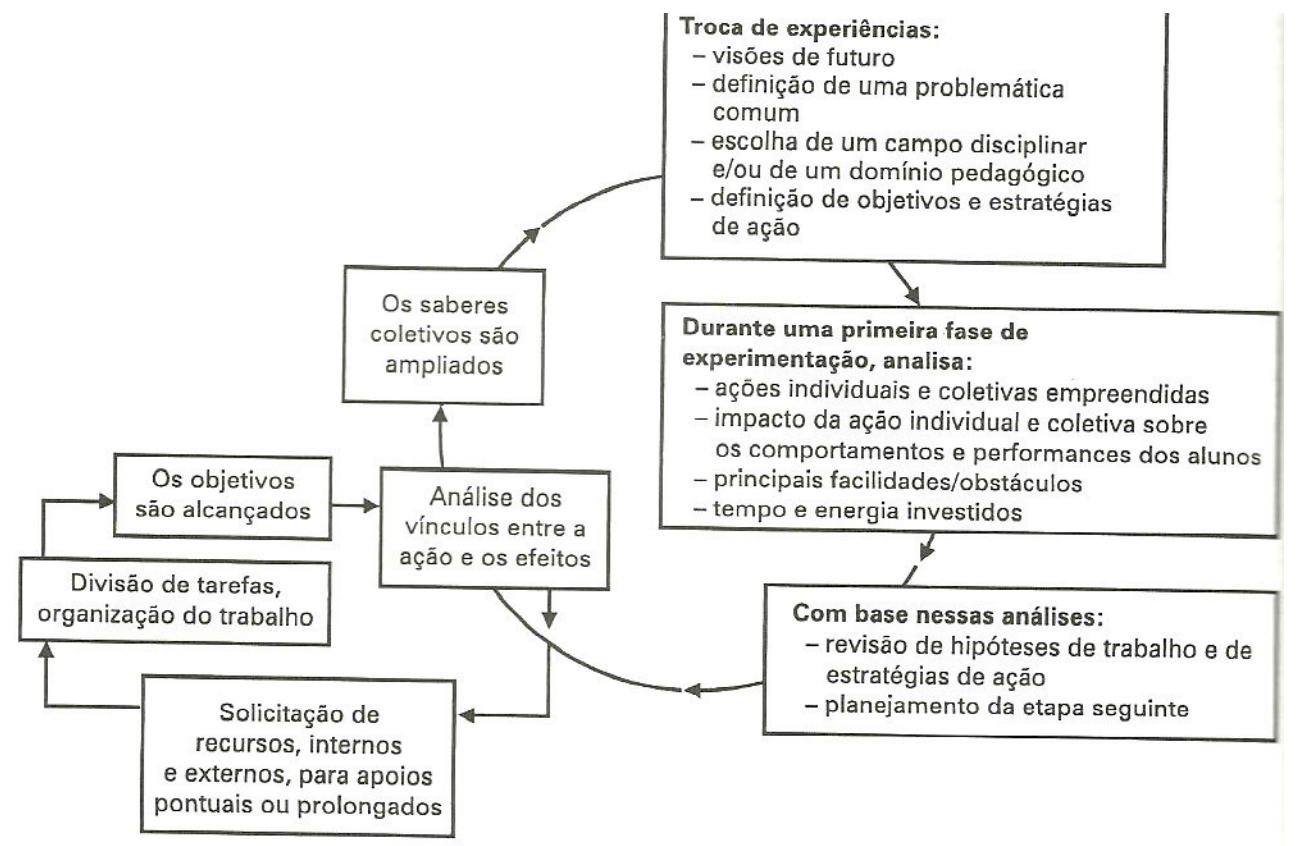

Fonte: Thurler (2002, p.102)

Com esta abordagem, a exploração colaborativa iniciou-se com a troca de experiências, a qual permitiu que todos (as) os professores (as) se conhecessem melhor e relatassem suas respectivas práticas educativas. Durante cada apresentação, os desempenhos dos alunos e a relevâncias das atividades eram discutidos e analisados. Ao longo do $1^{\circ}$ Semestre, a pesquisadora observou que os educadores (as) adotaram - ou descartaram - definitivamente algumas abordagens elaboradas, revisaram suas hipóteses de trabalho e suas estratégias de ação para ensinar Matemática a partir do diálogo interdisciplinar. Também notou que alguns professores sentiram necessidade de recorrer a 
recursos internos (colegas de outros anos ou de outras disciplinas) ou externos (especialistas em Matemática). O movimento de reorganização do trabalho e da divisão de tarefas foi evidente para que se conseguisse os meios mais adequados para atingir os objetivos do desafio lançado.

Ao final de cada partilha realizada nas Reuniões Pedagógicas, os (as) docentes avaliavam seus efeitos (tanto para os estudantes quanto para o seu próprio desenvolvimento profissional) e julgavam se o problema foi contornado e também se a problemática explorada mereceria ser prosseguida ou ampliada.

Thurler (2002) explica que a exploração colaborativa permite aos professores desenvolver uma compreensão melhor de seus gestos profissionais e dos processos de aprendizagem de seus alunos, ajudando-os a instaurar uma cooperação eficaz e duradoura. (THURLER, 2002, p. 103)

A seguir, os Quadros 2 a 10 apresentam as avaliações de cada partilha de experiência matemática interdisciplinar realizada pelos (as) educadores (as) da EI e do EFI do INSC, com os termos indicados pela pesquisadora, respeitando a sequência do cronograma mostrado anteriormente.

Quadro 2 - Avaliação da equipe docente da EI e do EFI sobre a partilha de experiência matemática interdisciplinar dos $1^{\text {os }}$ anos

\begin{tabular}{|c|c|}
\hline Excelente & $\begin{array}{l}\text { Sobre a proposta: } \\
\text { - O jogo apresentado trabalha as quantidades e promove a interação dos alunos; } \\
\text { - O jogo pode ser aplicado em diversas áreas; } \\
\text { - O reaproveitamento de materiais recicláveis para a construção do jogo; } \\
\text { - Auxílio para um trabalho sistematizado sobre o conteúdo de sequência numérica. } \\
\text { Sobre a apresentação: } \\
\text { - Boa organização e partilha clara e objetiva. }\end{array}$ \\
\hline Importante & $\begin{array}{l}\text { - Relembrar as regras, tirar possíveis dúvidas dos participantes, estar presente durante o jogo e } \\
\text { realizar as intervenções; } \\
\text { - Repetir o jogo, podendo mudar ou criar uma regra nova; } \\
\text { - A forma de associar a contagem dos números do dado com o tabuleiro; } \\
\text { - Aliar o jogo às atividades pedagógicas; (Continua) } \\
\text { (Continuação) - Perceber que por meio de jogos simples levanta-se hipóteses construindo } \\
\text { conhecimento. }\end{array}$ \\
\hline Sugestões & $\begin{array}{l}\text { - Em alguns casos pode-se usar o dado com números para fixar o reconhecimento; } \\
\text { - Para os estudantes da EI pensamos em um dado com as mãos mostrando o número, pois além de } \\
\text { trabalhar a Matemática faz com que a criança trabalhe a parte da motricidade; } \\
\text { - Propor para os alunos uma coleção de tampinhas; } \\
\text { - Variar o jogo incluindo a adição, dando a quantidade para o outro; } \\
\text { - Aproveitar a tabela com variadas cores das tampinhas, como um gráfico; } \\
\text { - Utilizar o conceito de "par ou ímpar" como regra para as jogadas; } \\
\text { - O jogo pode ser trabalhado nos anos seguintes, aprofundando o nível de exigência; } \\
\text { - Um tabuleiro com cores diferentes de tampinhas; } \\
\text { - Desafiar o aluno cada vez que for avançando no jogo; } \\
\text { - Realizar adaptações para alunos com dificuldades de aprendizagem e oferecer novos desafios. }\end{array}$ \\
\hline
\end{tabular}


Quadro 3 - Avaliação da equipe docente da EI e do EFI sobre a partilha de experiência matemática interdisciplinar do Infantil I (2 anos)

\begin{tabular}{|c|c|}
\hline Sensacional & $\begin{array}{l}\text { Sobre a proposta: } \\
\text { - Ideias de jogos; } \\
\text { - Observação diária dos alunos e pesquisa teórica para a prática; } \\
\text { - O trabalho com conceitos matemáticos; } \\
\text { - Proposta de jogo nos diferentes segmentos; } \\
\text { - Jogo desafiador. } \\
\text { Sobre a apresentação: } \\
\text { - Boa apresentação, bom planejamento e domínio do conteúdo; } \\
\text { - Clareza dos slides; } \\
\text { - Ótima apresentação, com ideias válidas e objetivas; } \\
\text {-Embasamento teórico, demonstrando saber o que estavam fazendo (o que, para quê, como...). }\end{array}$ \\
\hline $\begin{array}{c}\text { Desafio } \\
\text { cumprido! }\end{array}$ & $\begin{array}{l}\text { - Interdisciplinaridade no trabalho; } \\
\text { - Transmissão do trabalho realizado e aprendizagem das crianças; } \\
\text { - As professoras trabalharam de maneira lúdica e interativa; } \\
\text { - Planejamento e engajamento da dupla. }\end{array}$ \\
\hline Novas ideias & $\begin{array}{l}\text { - Palitos em grupos de várias quantidades, um número norteador e as cestas; } \\
\text { - Usar garrafas de tamanhos diferentes e quantidade de líquido ou papel par enchê-las; } \\
\text { "Igual ou diferente", com figuras; } \\
\text { - Jogo Boole; } \\
\text { - Entusiasmo ao ver a Matemática de uma forma diferente; } \\
\text { - Trabalhar gráficos; Grandezas e medidas; Jogo Boole online com níveis diferentes; montar } \\
\text { histórias com as cartas do jogo; } \\
\text { - Observação do ambiente utilizado para classificação. }\end{array}$ \\
\hline
\end{tabular}

Fonte: Arquivo pessoal.

Quadro 4 - Avaliação da equipe docente da EI e do EFI sobre a partilha de experiência matemática interdisciplinar dos $2^{\text {os }}$ Anos

\begin{tabular}{|c|c|}
\hline Bravo! & $\begin{array}{l}\text { Sobre a proposta: } \\
\text { - O lúdico trabalhando com vários conceitos da Matemática; Busca pelo "algo a mais"; Cantar, brincar } \\
\text { e se divertir; Aprendizado X Alegria. } \\
\text { Sobra a apresentação: } \\
\text { - Organização dos slides; Segurança das professoras quanto aos objetivos da atividade; Parceria; } \\
\text { Dinâmica prazerosa. }\end{array}$ \\
\hline Especial! & $\begin{array}{l}\text { - A integração da turma; momento de socialização; Uso adequado do vocabulário matemático; União } \\
\text { do conteúdo matemático a uma brincadeira conhecida; Entretenimento e aprendizado; "Carinha" de } \\
\text { cada criança; A prática do jogo e o envolvimento; Dinâmica alegre; jogo prático e envolvente; Refletir } \\
\text { sobre nosso vocabulário: ESTIMATIVA; INTERDISCIPLINARIDADE; Relembrar e resgatar as } \\
\text { brincadeiras da infância. }\end{array}$ \\
\hline $\begin{array}{c}\text { Fica a } \\
\text { dica! }\end{array}$ & $\begin{array}{l}\text { - Trabalhar a solidariedade como foi vivenciada no jogo, nas atividades diárias; Trabalhar com a adição } \\
\text { dos dados; Para a EI, trabalhar com os números dentro da caixa para o reconhecimento; Uso do } \\
\text { Material Dourado; Trabalhar a decomposição dos números; Utilizar todas as operações matemáticas; } \\
\text { Aumentar o número de pedras para que não fique apenas na unidade. }\end{array}$ \\
\hline
\end{tabular}

Fonte: Arquivo pessoal. 
Quadro 5 - Avaliação da equipe docente da EI e do EFI sobre a partilha de experiência matemática interdisciplinar do Infantil I (3 anos)

\begin{tabular}{|c|l|}
\hline & Sobre a proposta: \\
& - Conhecimento interdisciplinar; \\
& - A abordagem do tema e o planejamento das aulas; \\
& - O desenvolvimento das atividades foi pertinente e coerente com a faixa etária; \\
Hors & - O desenvolvimento do trabalho com etapas; \\
Concours & - Atividades excepcionais e bem preparadas, com objetivos ótimos! \\
& Sobre a apresentação: \\
& - Parceria; \\
& - Organização dos slides; \\
& - Planejamento do trabalho. \\
\hline Bom & - Envolvimento das crianças nas atividades; \\
trabalho! & - Organização dos conteúdos e registros; \\
\hline Já teve & - Cuidado para relacionar a teoria e a prática; \\
Sua novasibilidade gradativa de compreensão da criança; & - Técnica para diferenciar o quadrado do retângulo; \\
ideia & - Criar um livro tátil com as formas geométricas; \\
hoje? & - Trabalhar sequência lógica; \\
& - Reconhecer o diferente no todo; \\
& - Dominó dos blocos lógicos para as séries mais avançadas; \\
& - Trabalhar a área das figuras com os alunos dos $5^{\text {os }}$ Anos; \\
- Construir jogos de tabuleiro de formas para deixar na sala para uso cotidiano nos cantinhos. \\
\hline
\end{tabular}

Fonte: Arquivo pessoal.

Quadro 6: Avaliação da equipe docente da EI e do EFI sobre a partilha de experiência matemática interdisciplinar do Infantil II (4 anos)

\begin{tabular}{|c|c|}
\hline Excelente & $\begin{array}{l}\text { Sobre a proposta: } \\
\text { - Ficou claro o trabalho da Literatura com a Matemática; } \\
\text { - Estímulo do raciocínio lógico; } \\
\text { - Integração da história “A Arca de Noé” na formação de gráficos e jogos; } \\
\text { - Recursos motivacionais; } \\
\text { - Exposição dos personagens na sala (preparação do ambiente); } \\
\text { - Trabalho com o Eixo Tratamento da Informação } \\
\text { Sobre a apresentação: } \\
\text { - Slides bem explicados e material impresso; } \\
\text { - Capricho e cuidado com os materiais. }\end{array}$ \\
\hline $\begin{array}{c}\text { Uma } \\
\text { grande } \\
\text { lição }\end{array}$ & $\begin{array}{l}\text { - O carinho, a criatividade, o planejamento entre a Literatura e a Matemática; } \\
\text { - Trabalhar gráfico, contagem e o trabalho interdisciplinar do livro da RSE da EI (Caleidoscópio) com } \\
\text { o Projeto de Leitura; } \\
\text { - Trabalhar perdas e saber respeitar o próximo; } \\
\text { - Criatividade nas intervenções. }\end{array}$ \\
\hline $\begin{array}{c}\text { Como abrir a } \\
\text { mente e ser } \\
\text { mais criativo? }\end{array}$ & $\begin{array}{l}\text { - Continuar sendo pesquisadoras! Quem pesquisa, estuda e sabe criar. } \\
\text { - Companheirismo, união e parceria entre os profissionais; } \\
\text { - Gráficos variados (com outros dados); } \\
\text { - No jogo "Corrida dos Bichos", os alunos podem ser os bichos e devem dar passos de acordo com a } \\
\text { quantidade tirada no dado; } \\
\text { - Utilização de potes para fazer boliche. }\end{array}$ \\
\hline
\end{tabular}

Fonte: Arquivo pessoal. 
Quadro 7: Avaliação da equipe docente da EI e do EFI sobre a partilha de experiência matemática interdisciplinar do $3^{\text {os }}$ Anos

\begin{tabular}{|c|c|}
\hline $\begin{array}{l}\text { Elogiar... } \\
\text { Reconhecer... } \\
\text { Agradecer... }\end{array}$ & $\begin{array}{l}\text { Sobre a proposta: } \\
\text { - Planejamento, desenvolvimento e finalização da atividade; } \\
\text { - Interdisciplinaridade; } \\
\text { - Escolha do Eixo Espaço e Formas. } \\
\text { Sobre a apresentação: } \\
\text { - Organização e escolha de imagens para os slides. }\end{array}$ \\
\hline $\begin{array}{c}\text { Acertando o } \\
\text { alvo }\end{array}$ & $\begin{array}{l}\text { - Desenvolver os conteúdos por meio da ludicidade; } \\
\text { - Organização e tempo; } \\
\text { - Explorar objetos do dia a dia e correlacioná-los com o conteúdo trabalhado; } \\
\text { - Atividade criativa e prazerosa. }\end{array}$ \\
\hline Boa ideia & $\begin{array}{l}\text { - Refazer a proposta sempre que possível; } \\
\text { - Explorar a descrição, que é um gênero textual da Língua Portuguesa com a } \\
\text { Matemática; } \\
\text { - Observação dos sólidos antes de aplicar a atividade. }\end{array}$ \\
\hline
\end{tabular}

Fonte: Arquivo pessoal.

Quadro 8: Avaliação da equipe docente da EI e do EFI sobre a partilha de experiência matemática interdisciplinar dos $4^{\text {os }}$ Anos

\begin{tabular}{|c|c|}
\hline $\begin{array}{c}\text { Sucesso é a } \\
\text { nossa cara }\end{array}$ & $\begin{array}{l}\text { Sobre a proposta: } \\
\text { - Trabalho realizado por meio da contação de histórias; } \\
\text { - Importância de trabalhar os conceitos matemáticos; } \\
\text { - Exploração do conteúdo, trabalhando de uma maneira prazerosa e utilizando os materiais } \\
\text { vistos no livro escolhido; } \\
\text { - Trabalho interdisciplinar; } \\
\text { - Integração da teoria com a prática e da língua materna com a Matemática; } \\
\text { - Preocupação com a função social; } \\
\text { - Escolha do livro paradidático; } \\
\text { Sobre a apresentação: } \\
\text { - Preparo da dupla de professoras; } \\
\text { - Clareza no conteúdo exposto; } \\
\text { - Explicação do desenvolvimento do trabalho. }\end{array}$ \\
\hline $\begin{array}{l}\text { Missão } \\
\text { dada... é } \\
\text { missão } \\
\text { cumprida! }\end{array}$ & $\begin{array}{l}\text { - Alcance da aprendizagem sobre Grandezas e Medidas por meio da prática e participação } \\
\text { ativa dos alunos; } \\
\text { - Abordagem do conteúdo com extrema segurança e foco nos objetivos; } \\
\text { - Participação dos alunos; } \\
\text { - Organização dos materiais e domínio do conteúdo. }\end{array}$ \\
\hline Eureka! & $\begin{array}{l}\text { - Indicação do livro: "Os problemas da família Gorgonzola”, que trabalha situações- } \\
\text { problema, números e operações matemáticas; } \\
\text { - Criar e recriar um novo livro, partindo dos conceitos relatados, realizando uma aliança } \\
\text { com a livro de Língua Portuguesa; } \\
\text { - Trabalhar o diâmetro; } \\
\text { - Fazer uma receita explorando as medidas de capacidade. } \\
\text { - Estabelecer a diferença entre massa e peso; } \\
\text { - Fazer um glossário matemático com a turma. }\end{array}$ \\
\hline
\end{tabular}


Quadro 9: Avaliação da equipe docente da EI e do EFI sobre a

partilha de experiência matemática interdisciplinar do Infantil III (5 anos)

\begin{tabular}{|c|c|}
\hline Bravo! & $\begin{array}{l}\text { Sobre a proposta: } \\
\text { - Diversos conhecimentos integrados; Interação dos alunos; Trabalho com a linguagem oral e } \\
\text { escrita (regras do jogo); Interdisciplinaridade: Matemática e Artes; Didática da aplicação do } \\
\text { projeto. } \\
\text { Sobre a apresentação: } \\
\text { - União/parceria da dupla de professoras; Utilização do tempo adequado; Clareza e segurança } \\
\text { durante a apresentação; Dedicação e segurança; Apresentação dos registros fotográficos; }\end{array}$ \\
\hline $\begin{array}{l}\text { Keep } \\
\text { Calm and } \\
\text { Missão } \\
\text { Cumprida }\end{array}$ & $\begin{array}{l}\text { - Organização do ambiente para o momento do jogo; Mobilização das crianças; O } \\
\text { desenvolvimento da aprendizagem dos alunos durantes as fases aplicadas do jogo; Resultados; } \\
\text { atenção das crianças; registros; A concentração e o envolvimento dos alunos; }\end{array}$ \\
\hline $\begin{array}{c}\text { Ideias em } \\
\text { ação }\end{array}$ & $\begin{array}{l}\text { - Desafiar os alunos a completar o tabuleiro em ordem decrescente; } \\
\text { - Confeccionar formar grandes e colocar os alunos como peças do jogo; } \\
\text { - Utilizar as formas e os números em outros jogos de tabuleiro; } \\
\text { - Completar a sequência das formas: começar no nível fácil e aumentar o desafio }\end{array}$ \\
\hline
\end{tabular}

Fonte: Arquivo pessoal.

Quando 10: Avaliação da equipe docente da EI e do EFI sobre a partilha de experiência matemática interdisciplinar dos $5^{\circ \mathrm{s}}$ Anos

\begin{tabular}{|c|l|}
\hline & $\begin{array}{l}\text { Sobre a proposta: } \\
\text { - Interdisciplinaridade; } \\
\text { - Junção de atividades entre Projeto de Leitura e Malba Tahan. Uma aula completou a outra; } \\
\text { - Envolvimento dos alunos e a apresentação do teatro pelos alunos. } \\
\text { Sobre a apresentação: } \\
\text { Espetacular! }\end{array}$ \\
$\begin{array}{l}\text { - Explicação dos conteúdos de Matemática; } \\
\text { - Entrosamento e parceria das professoras; } \\
\text { - Domínio do conteúdo; } \\
\text { - Planejamento, desenvolvimento e motivação inicial em Língua Portuguesa; }\end{array}$ \\
$\begin{array}{c}\text { Aprendizagem } \\
\text { - Apresentação dos slides, encarte e projeto; } \\
\text { - Entusiasmo em ensinar. }\end{array}$ \\
$\begin{array}{c}\text { Significativa } \\
\text { - Momento criativo de aprendizagem com prazer; }\end{array}$ \\
$\begin{array}{c}\text { - Aluno como protagonista da aprendizagem; } \\
\text { - Exploração de vários conceitos em uma aula; } \\
\text { "A mente que se } \\
\text { abre a uma nova } \\
\text { ideia jamais } \\
\text { voltará ao seu } \\
\text { tamanho original" } \\
\text { (A. Einstein) }\end{array}$ & $\begin{array}{l}\text { - Criar uma situação-problema que poderá ser feita em casa e problematizada em sala; } \\
\text { - Trabalhar o que foi feito no círculo de papel numa receita de bolo, torta ou pizza; } \\
\text { - Trabalhar um livro com outros temas. }\end{array}$ \\
\hline
\end{tabular}

Fonte: Arquivo pessoal.

Analisando os Quadros 2 a 10, podemos afirmar que esta proposta aproximou os professores das necessidades pedagógicas, o que tornou a prática elemento de análise e reflexão. Isso exigiu um compromisso com a socialização profissional, entendendo-a parte da formação associada a uma troca "crítica" de experiências. Também foi observado que 
desvelar as práticas pedagógicas à equipe docente não é uma tarefa fácil, assim como é difícil para o grupo analisar o trabalho dos colegas de profissão.

De fato, devemos considerar o acompanhamento articulador da pesquisadora, que é a Coordenadora Pedagógica dos segmentos da EI e do EFI, durante todo o processo de planejamento, desenvolvimento e apresentação de cada partilha, conduzindo o projeto formativo e despertando maior envolvimento dos educadores participantes, para que durante as apresentações das propostas interdisciplinares realizadas em cada turma, as professoras não dissessem aquilo que a pesquisadora queria ouvir, mas sim expusessem a prática que realizam e em que acreditam.

Pensar sobre a gestão da formação permanente na escola é oportunizar uma discussão sobre as possibilidades de organização do espaço/tempo formador e isto denota escolhas baseadas em concepções. Não é uma decisão neutra, mas a adesão ou não de um projeto coletivo em razão de um aperfeiçoamento da prática docente.

\subsection{Etapas do trabalho com os estudantes dos $5^{\circ}$ Anos: analisando o processo}

Foram desenvolvidas três etapas com 46 estudantes dos $5^{\text {os }}$ Anos do EFI. Para melhor organização da análise e discussão, cada uma será apresentada na sequência em que foram realizadas. Iniciaremos com a Etapa I, como mostra o Quadro 11:

Quadro 11 - Plano de Ação da Etapa I: Desafios Matemáticos

\begin{tabular}{|c|c|c|c|c|c|}
\hline Quando? & O quê? & Como? & Quem? & Onde? & Para quê? \\
\hline $\begin{array}{c}4^{\mathrm{a}} \text { aula } \\
50 \text { minutos }\end{array}$ & $\begin{array}{l}\text { Avaliação } \\
\text { diagnóstica }\end{array}$ & $\begin{array}{c}\text { Pré-teste com questões } \\
\text { contemplando três eixos da } \\
\text { Matemática: Números e operações, } \\
\text { Espaço e Forma e Grandezas e } \\
\text { Medidas. }\end{array}$ & $\begin{array}{c}\text { Pesquisadora, } \\
\text { Prof a da classe } \\
\text { e Estudantes } \\
\text { dos } 5^{\circ} \text { Anos }\end{array}$ & Classe & $\begin{array}{c}\text { Diagnosticar o } \\
\text { conhecimento } \\
\text { dos estudantes } \\
\text { referentes aos } \\
\text { quatro eixos } \\
\text { estudados até o } \\
\text { final do } 4^{\circ} \text { Ano } \\
\text { do EFI. }\end{array}$ \\
\hline $\begin{array}{c}1^{\mathrm{a}} \text { aula } \\
20 \text { minutos }\end{array}$ & $\begin{array}{l}\text { Apresentação } \\
\text { do escritor } \\
\text { Malba Tahan. }\end{array}$ & $\begin{array}{c}\text { Dramatização durante o “Boa } \\
\text { tarde". Texto base: O que é, o que } \\
\text { é?", Prof. Dr. Pedro Paulo Salles, } \\
\text { 1995. Disponível em? } \\
\frac{\text { http://www.malbatahan.com.br/arti }}{\text { gos/artigo pedropaulo salles.'df }} \\
\text { Acesso em 15/01/2015 }\end{array}$ & $\begin{array}{l}\text { Pesquisadora, } \\
\text { Prof da classe } \\
\text { e Estudantes } \\
\text { dos } 5^{\text {os }} \text { Anos }\end{array}$ & Salão Social & $\begin{array}{c}\text { Apresentar a } \\
\text { vida e algumas } \\
\text { obras de Malba } \\
\text { Tahan } \\
\\
\text { (Continua...) }\end{array}$ \\
\hline
\end{tabular}




\begin{tabular}{|c|c|c|c|c|c|}
\hline Quando? & O quê? & Como? & Quem? & Onde? & Para quê? \\
\hline $\begin{array}{c}\text { (Continuação } \\
\text { do Quadro } \\
\text { 11) } \\
4^{\mathrm{a}} \text { aula } \\
50 \text { minutos }\end{array}$ & $\begin{array}{l}\text { - Formação } \\
\text { dos grupos, } \\
\text { atribuição de } \\
\text { funções } \\
\text { dentro do } \\
\text { grupo } \\
\text { - Distribuição } \\
\text { de tarefas. } \\
\text {-Apresentação } \\
\text { do artigo (com } \\
\text { dramatização } \\
\text { da Meily) e do } \\
\text { desafio } \\
\text { matemático. }\end{array}$ & $\begin{array}{c}\text { - Formar os grupos interativos a } \\
\text { partir da avaliação diagnóstica } \\
\text { realizada no dia } 30 / 01 \text {. Entregar } \\
\text { uma lista de tarefas para os } \\
\text { componentes das equipes. } \\
\text { - Artigo:”Origem dos Números" (p. } \\
7 \text { a 11); Livro Antologia da } \\
\text { Matemática (2) } \\
\text { - Desafios sobre o Eixo Números e } \\
\text { Operações: "Quadrados Mágicos" } \\
\text { (p. } 224 \text { e 225) e "Adivinhação" (p. } \\
218 \text { e 219), Livro Didática da } \\
\text { Matemática 2. }\end{array}$ & $\begin{array}{l}\text { Pesquisadora, } \\
\text { Prof }^{\mathrm{a}} \text { da classe } \\
\text { e Estudantes } \\
\text { dos } 5^{\mathrm{os}} \text { Anos }\end{array}$ & $\begin{array}{c}\text { Laboratório de } \\
\text { MATEMÁTICA }\end{array}$ & $\begin{array}{l}\text { - Apresentar aos } \\
\text { educandos a } \\
\text { parte histórica } \\
\text { da Matemática; } \\
\text { Continua } \\
\\
\text { - Mostrar a } \\
\text { relação entre o } \\
\text { Folclore e a } \\
\text { Matemática; } \\
\text { - Propor aos } \\
\text { estudantes uma } \\
\text { recreação } \\
\text { numérica. }\end{array}$ \\
\hline $\begin{array}{c}4^{\mathrm{a}} \text { aula } \\
50 \text { minutos }\end{array}$ & $\begin{array}{c}\text { Apresentação } \\
\text { do artigo (com } \\
\text { dramatização } \\
\text { da Meily) e do } \\
\text { desafio } \\
\text { matemático. }\end{array}$ & $\begin{array}{l}\text { - Artigo I: “A origem da } \\
\text { Geometria" (p. 123 a 125); Livro } \\
\text { Antologia da Matemática. Artigo II: } \\
\text { "Um polígono na poesia", p. } 57 \text { e } \\
\text { 58; Livro Matemática Divertida e } \\
\text { Delirante. } \\
\\
\text { - Desafio matemático sobre o Eixo } \\
\text { Espaço e Forma: "A história do } \\
\text { Tangram". Disponível em: } \\
\frac{\text { https://www.youtube.com/watch?v }}{\text { =R0kLmupaoOk Acesso em }} \\
06 / 01 / 2015\end{array}$ & $\begin{array}{l}\text { Pesquisadora, } \\
\text { Prof }^{\mathrm{a}} \text { da classe } \\
\text { e Estudantes } \\
\text { dos } 5^{\mathrm{os}} \text { Anos }\end{array}$ & $\begin{array}{c}\text { Laboratório de } \\
\text { MATEMÁTICA }\end{array}$ & $\begin{array}{c}\text { Apresentar aos } \\
\text { educandos a } \\
\text { parte histórica } \\
\text { da Matemática; } \\
\text { empregar o } \\
\text { quebra-cabeça } \\
\text { Tangran para o } \\
\text { raciocínio } \\
\text { lógico e para o } \\
\text { estudo da } \\
\text { geometria e das } \\
\text { formas. }\end{array}$ \\
\hline $\begin{array}{c}2^{\mathrm{a}} \text { aula } \\
50 \text { minutos }\end{array}$ & $\begin{array}{l}\text { Apresentação } \\
\text { do artigo (com } \\
\text { dramatização } \\
\text { da Meily) e do } \\
\text { jogo. }\end{array}$ & $\begin{array}{l}\text { - Artigo: “As medidas de tempo na } \\
\text { roça e na cidade", p. } 134 \text { a 142; } \\
\text { Livro Meu Anel de Sete Pedras. } \\
\text { - Jogo sobre o Eixo Grandezas e } \\
\text { Medidas: "Memória dos relógios: } \\
\text { analógico e digital", apostila "Jogos } \\
\text { de Matemática" (Planeta Educação) }\end{array}$ & $\begin{array}{c}\text { Pesquisadora, } \\
\text { Prof }^{\mathrm{a}} \text { da classe } \\
\text { e Estudantes } \\
\text { dos } 5^{\mathrm{os}} \text { Anos }\end{array}$ & $\begin{array}{l}\text { Laboratório de } \\
\text { MATEMÁTICA } \\
\\
\text { - Salão Social e } \\
\text { Espaço Social I }\end{array}$ & $\begin{array}{l}\text { Mostrar a } \\
\text { relação entre o } \\
\text { Folclore e a } \\
\text { Matemática; } \\
\text { fazer a relação } \\
\text { entre as horas } \\
\text { de um relógio } \\
\text { digital e um } \\
\text { analógico. }\end{array}$ \\
\hline $\begin{array}{c}4^{\mathrm{a}} \text { aula } \\
50 \text { minutos }\end{array}$ & $\begin{array}{c}- \\
\text { Apresentação } \\
\text { do artigo (com } \\
\text { dramatização } \\
\text { da Meily) e do } \\
\text { desafio } \\
\text { matemático. } \\
\text { - } \\
\text { Encerramento } \\
\text { da etapa com } \\
\text { a produção de } \\
\text { um portfólio } \\
\text { com as } \\
\text { atividades dos } \\
\text { alunos. }\end{array}$ & $\begin{array}{l}\text { - Fragmentos do artigo: "O dez nas } \\
\text { parlendas infantis"; “Dez, o número } \\
\text { universal” (p. } 304 \text { a 313); Livro Os } \\
\text { Números Governam o Mundo. } \\
\text { - Desafio matemático sobre o Eixo } \\
\text { Tratamento de Informação: "Jogo } \\
\text { do Dez", apostila "Jogos de } \\
\text { Matemática" (Planeta Educação). }\end{array}$ & $\begin{array}{c}\text { Pesquisadora, } \\
\text { Prof }^{\mathrm{a}} \text { da classe } \\
\text { e Estudantes } \\
\text { dos } 5^{\text {os }} \text { Anos }\end{array}$ & $\begin{array}{l}\text { Laboratório de } \\
\text { MATEMÁTICA }\end{array}$ & $\begin{array}{l}\text { - Apresentar aos } \\
\text { educandos a } \\
\text { parte histórica } \\
\text { da Matemática; } \\
\text { mostrar a } \\
\text { relação entre o } \\
\text { Folclore e a } \\
\text { Matemática; } \\
\text { permitir ao } \\
\text { aluno inserir } \\
\text { dados em uma } \\
\text { tabela. } \\
\text { (Concluído) }\end{array}$ \\
\hline
\end{tabular}

Fonte: autoria própria.

6 Na obra "Didática da Matemática" (1962), Malba Tahan sugere que o professor tente, por meio do Laboratório, propor que o estudante exercite o raciocínio e não apenas brinque com as experiências. O Laboratório de Matemática do INSC foi inaugurado durante o $1^{\circ}$ Semestre de 2015. A proposta desta sala ambiente é fruto da pesquisa intitulada "Laboratório de Ensino de Matemática: Aplicação de recursos pedagógicos para o ensino de função e trigonometria" da Professora Diana Vieira de Carvalho, também do Programa de Pós-Graduação da EEL/USP em Projetos Educacionais de Ciências. 
Com o objetivo de diagnosticar o conhecimento dos estudantes referentes aos quatro eixos estudados até o final do $4^{\circ}$ Ano do EFI, foi aplicada uma Avaliação Diagnóstica Inicial (Anexo C) contemplando três eixos da Matemática: Números e Operações, Espaço e Forma e Grandezas e Medidas, tendo como fonte as questões elaboradas pela SARESP (Sistema de Avaliação do Rendimento Escolar do Estado de São Paulo) que é um programa que avalia o sistema de ensino paulista com a intenção de identificar o rendimento escolar dos alunos dos ensinos Fundamental e Médio e do SAEB/Prova Brasil (Sistema Nacional de Avaliação da Educação Básica), que é uma ação do Governo Brasileiro, desenvolvido pelo Instituto Nacional de Estudos e Pesquisas Educacionais Anísio Teixeira, sendo um dos mais amplos esforços empreendidos em nosso País no sentido de coletar dados sobre alunos, professores, diretores de escolas públicas e privadas em todo o Brasil.

Os Eixos e os Descritores das questões da Avaliação Diagnóstica Inicial de Matemática estão detalhados no Quadro 12:

Quadro 12 - Eixos e Descritores das Questões da Avaliação Diagnóstica Inicial de Matemática

\begin{tabular}{|c|c|l|}
\hline Questões & \multicolumn{1}{|c|}{ Eixos } & \multicolumn{1}{|c|}{ Descritores } \\
\hline Questão 1 & Espaço e Forma & $\begin{array}{l}\text { 2. Identificar propriedades comuns diferenças entre } \\
\text { poliedros e corpos redondos, relacionando figuras } \\
\text { tridimensionais com suas planificações. }\end{array}$ \\
\hline Questão 2 & Grandezas e Medidas & $\begin{array}{l}\text { 7. Resolver problemas significativos utilizando unidades de } \\
\text { medida padronizadas como cm. }\end{array}$ \\
\hline Questão 3 & Números e Operações & $\begin{array}{l}\text { 13. Reconhecer e utilizar características do sistema de } \\
\text { numeração decimal, tais como agrupamentos e trocas na base } \\
10 \text { e princípio do valor posicional. }\end{array}$ \\
\hline Questão 4 & Grandezas e Medidas & $\begin{array}{l}\text { 12. Resolver problema envolvendo o cálculo ou a estimativa } \\
\text { de áreas de figuras planas, desenhadas em malhas } \\
\text { quadriculadas. }\end{array}$ \\
\hline Questão 5 & Espaço e Forma & $\begin{array}{l}\text { 3. Identificar propriedades comuns e diferenças entre figuras } \\
\text { bidimensionais pelo número de lados, pelos tipos de ângulos. }\end{array}$ \\
\hline Questão 6 & Números e Operações & $\begin{array}{l}\text { 23. Resolver problema utilizando a escrita decimal de cédulas } \\
\text { e moedas do sistema monetário brasileiro. }\end{array}$ \\
\hline Questão 7 & Grandezas e Medidas & $\begin{array}{l}\text { 9. Estabelecer relações entre o horário de início e término } \\
\text { e/ou o intervalo da duração de um evento ou acontecimento. }\end{array}$ \\
\hline Questão 8 & Números e Operações & $\begin{array}{l}\text { 18. Calcular o resultado de uma multiplicação ou divisão de } \\
\text { números naturais. }\end{array}$ \\
\hline Questão 9 & Números Operações & $\begin{array}{l}20 . \text { Resolver problema com números naturais, envolvendo } \\
\text { diferentes significados da multiplicação ou divisão: } \\
\text { multiplicação comparativa, ideia de proporcionalidade [... }\end{array}$ \\
\hline Fuestão 10 & Números e Operações & $\begin{array}{l}13 . \text { Reconhecer e utilizar características do sistema de } \\
\text { numeração decimal, tais como agrupamentos e trocas na base } \\
10 \text { e princípio do valor posicional. }\end{array}$ \\
\hline
\end{tabular}

Fonte: Matriz de Referência de Matemática do $5^{\circ}$ ano do EFI, INEP. Acesso em 20 de janeiro de 2015. 
Os resultados da Avaliação Diagnóstica Inicial realizada com as duas turmas do $5^{\circ}$ ano do EFI do Instituto Nossa Senhora do Carmo de 2015 estão representados nos seguintes Figuras 10 e 11:

Figura 10 - Gráfico do resultado da Avaliação Diagnóstica Inicial da Turma 1.

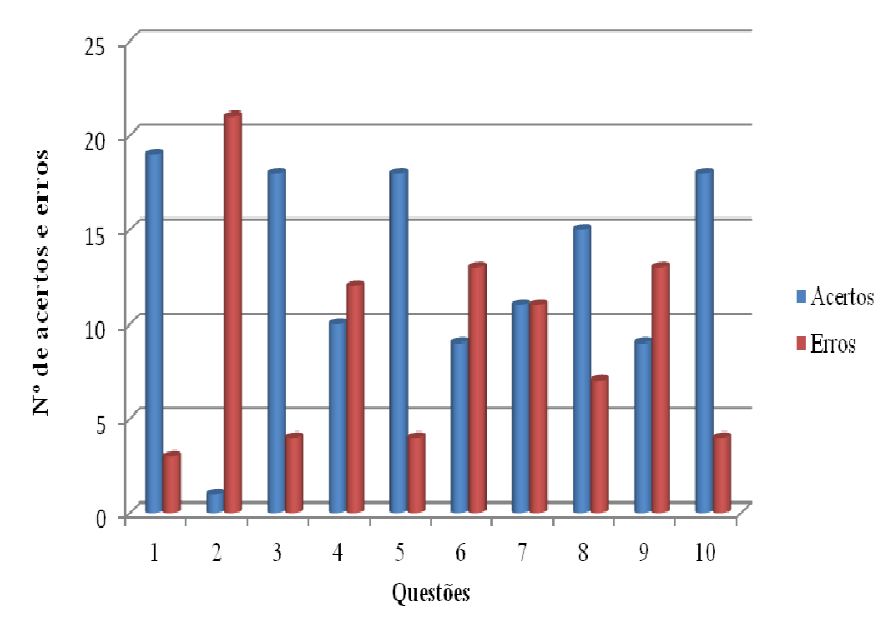

Fonte: Arquivo pessoal.
Figura 11 - Gráfico do resultado da Avaliação Diagnóstica Inicial da Turma 2.

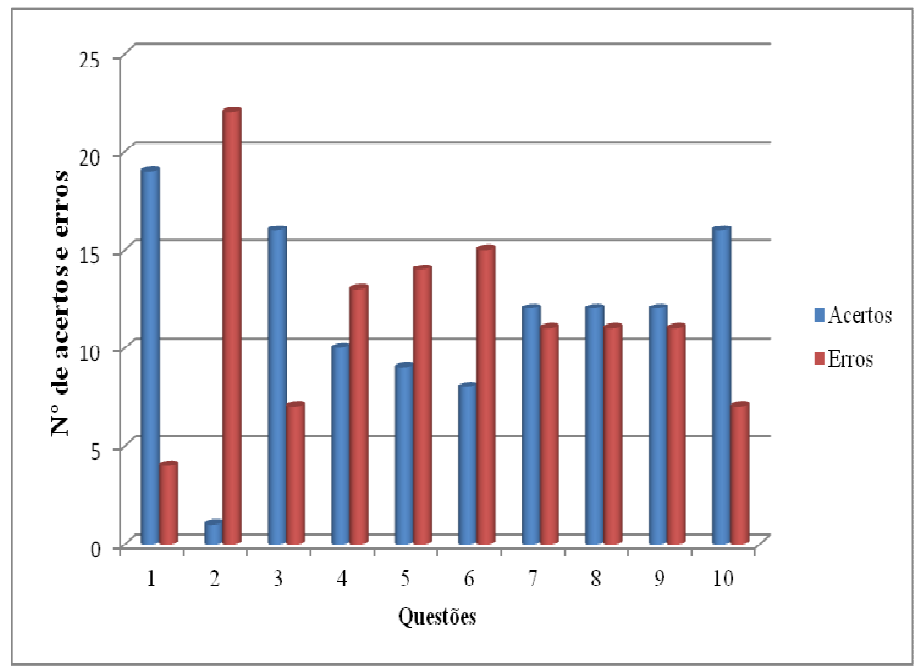

Fonte: Arquivo pessoal.

Verificou-se na Figura 10 que a questão com o maior índice de dificuldade foi a número 2 (21 erros), cujo Eixo é Grandezas e Medidas e o descritor é o 7: resolver problemas significativos utilizando unidades de medida padronizadas como $\mathrm{cm}$. $\mathrm{O}$ alto número de erros provavelmente ocorreu pelo fato dos estudantes não terem se apropriado de tal conteúdo durante o $4^{\circ}$ Ano do EFI. A questão 1 atingiu o maior número de acertos: 19. Observa-se que no Eixo Espaço e Forma os alunos têm maior entendimento quando o descritor é identificar propriedades comuns e diferenças entre poliedros e corpos redondos, relacionando figuras tridimensionais com suas planificações, possivelmente porque tal descritor é muito bem explorado pelos (as) Professoras do EFI, a partir de atividades propostas nos livros de Matemática da Rede Salesiana de Escolas.

Coincidência ou não, a Avaliação Diagnóstica Inicial feita pelos estudantes da Turma 2 também apresentou a mesma característica com relação às questões 2 e 1, como mostra a Figura 11. Dos 23 alunos, 22 erraram a questão 2, enquanto que na questão 1, 19 acertaram. Notou-se, então, a defasagem no Descritor 7 do Eixo Grandezas e Medidas e a compreensão efetiva do Descritor 2 do Eixo Espaço e Formas. 
Fazendo um comparativo geral entre as duas turmas, pelo fato do número de alunos ser próximo, a Figura 12 mostra que os alunos da Turma 1 acertaram mais questões da Avaliação Diagnóstica Inicial (128 acertos), enquanto que os da Turma 2 atingiram um maior número de erros (115).

Figura 12 - Gráfico dos resultados da Avaliação Diagnóstica Inicial de Matemática (Turmas 1 e 2).

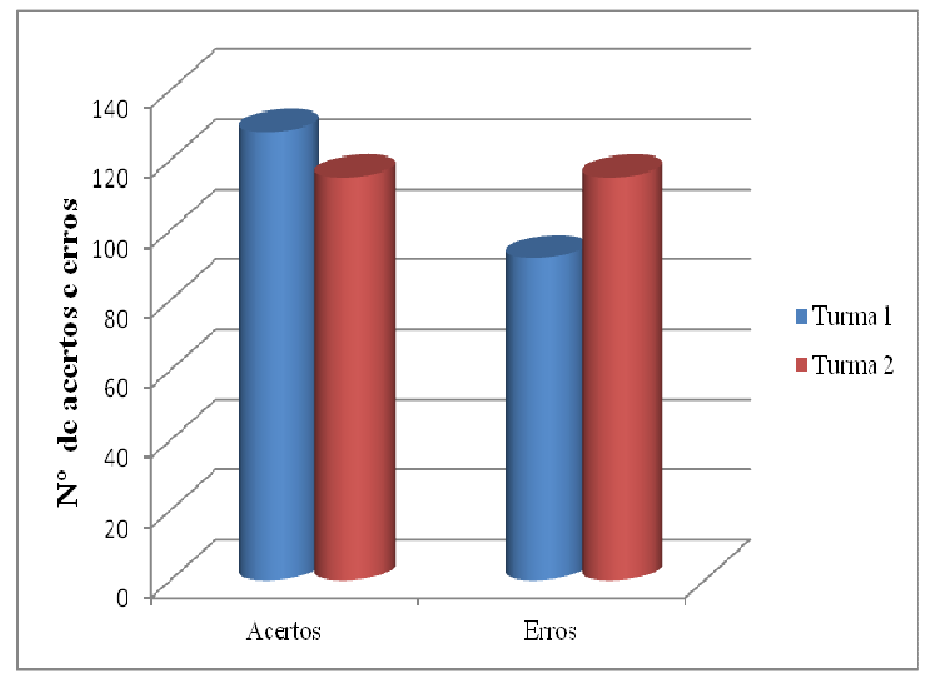

Fonte: Arquivo pessoal.

Em outro dia, foi realizada a motivação do trabalho durante o "Boa Tarde" do EFI no Salão Social do Colégio do Carmo. O "Boa Tarde" é momento especial de acolhida em toda escola salesiana realizado no início da tarde, com os estudantes reunidos em um mesmo local. A pesquisadora contou neste momento fatos da vida de Malba Tahan, utilizando como recursos a caracterização e um baú de histórias. Apresentou os livros escritos por este matemático, explorando os elementos de suas histórias e a caracterização da cultura árabe. Após este momento, os alunos foram convidados a aprender a Matemática a partir dos textos escritos por Malba Tahan e por meio de sua prática educativa.

$\mathrm{O}$ encontro inicial com os estudantes dos $5^{\mathrm{os}}$ Anos, em específico, teve como proposta central a organização dos 'Grupos Interativos' de estudo. Após a pesquisadora apresentar o Plano de Ação aos estudantes no Laboratório de Matemática, ambiente organizado com mesas circulares para favorecer o trabalho em grupos, as professoras parceiras dividiram as turmas em cinco equipes fixas, o mais heterogêneas possível. Tratava-se de colocar, juntos, a maior diversidade no que se refere às etapas de aprendizado: avançado (alunos que demonstram conhecimentos e domínio dos conteúdos, 
competências e habilidades além do requerido para o ano escolar em que se encontram); proficiente (alunos que demonstram conhecimentos e domínio dos conteúdos, competências e habilidades requeridos para o ano escolar em que se encontram), básico (alunos que demonstram desenvolvimento parcial dos conteúdos, competências e habilidades requeridos para o ano escolar em que se encontram) e abaixo do básico (alunos que demonstram domínio insuficiente dos conteúdos, competências e habilidades requeridos para o ano escolar em que se encontram).

Assim, formados os grupos interativos, os membros conversaram e decidiram quem se responsabilizaria por cada função: líder, $1^{\circ}$ e $2^{\circ}$ secretários, já que isto facilitaria a dinâmica das atividades propostas, favorecendo duas funções fundamentais: organizativa (controle e gestão da classe) e de convivência, segundo Zabala (1998, p. 123-125). Também definiram os seguintes nomes para os grupos, conforme o Quadro 13:

Quadro 13 - Nomes dos Grupos Interativos definidos pelos estudantes

\begin{tabular}{|c|c|c|}
\hline GRUPOS & TURMA 1 & TURMA 2 \\
\hline I & Os Matemáticos I & Os Sábios da Matemática \\
\hline II & Os Matemáticos II & As fórmulas \\
\hline III & Os Matemáticos III & Adição \\
\hline IV & Os Multiplicadores & Subtração \\
\hline V & Os Divisores & Divisão \\
\hline
\end{tabular}

Fonte: autoria própria.

A cada semana foi distribuído um artigo de Malba Tahan e/ou um desafio matemático para cada grupo. O artigo era apresentado, dramatizado e/ou lido pela pesquisadora e pelos educandos durante 15 a 20 minutos, cada um sobre um conteúdo comunicado previamente pela pesquisadora durante as aulas, contemplando os quatro eixos da Matemática: Números e Operações, Espaço e Forma, Grandezas e Medidas e Tratamento da Informação.

Cada grupo interativo foi dinamizado pela pesquisadora, que contou com a parceria da professora de Matemática dos $5^{\mathrm{os}}$ Anos. A proposta foi trazer uma grande riqueza em relação às diferentes soluções e argumentações colocadas, garantindo que se produzisse a interação entre os grupos organizados.

Para tratar do Eixo Número e Operações, foi apresentado e encenado pela pesquisadora o artigo de Malba Tahan: "Origem dos Números" (1961, p. 7 a 12, ANEXO D), do Livro Antologia da Matemática ( $2^{\circ}$ Volume). Em seguida, foram propostos dois 
desafios: "Quadrados Mágicos" (1961. p. 224 e 225) e “Adivinhação” (1961, p. 218 e 219), Livro Didática da Matemática ( $2^{\circ}$ Volume).

O enunciado do desafio dos "Quadrados Mágicos” (TAHAN, 1961, p. 224 e 225) propunha: "Pensem e completem o quadrado mágico com o algarismo de 1 a 9. A soma nas horizontais, nas verticais e nas diagonais deverá ser igual a 15. Obs.: cada algarismo só pode aparecer uma vez!”. As Figuras 13 e 14 apresentam, como exemplo, a resolução de um grupo interativo de cada turma que cumpriu o desafio, após partilharem suas tentativas:

Figura 13 - Resolução do desafio "Quadrados Mágicos" do Grupo Interativo I (Turma 1).

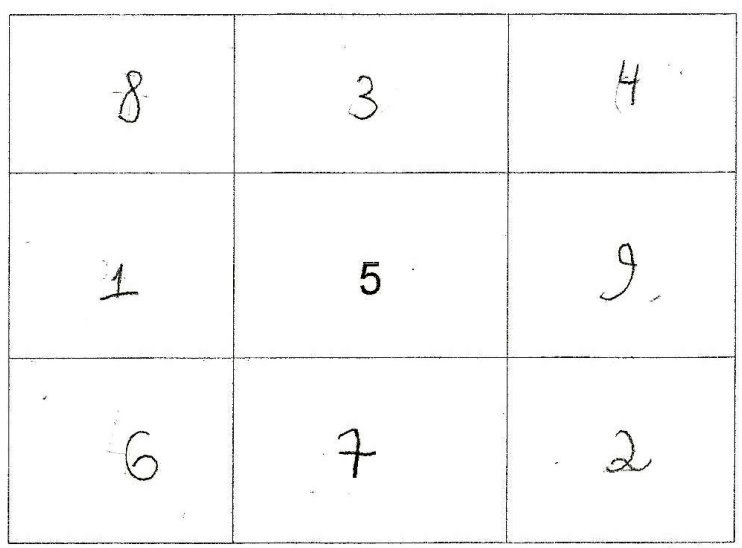

Fonte: Arquivo pessoal.
Figura 14 - Resolução do desafio "Quadrados Mágicos” do Grupo Interativo III (Turma 2).

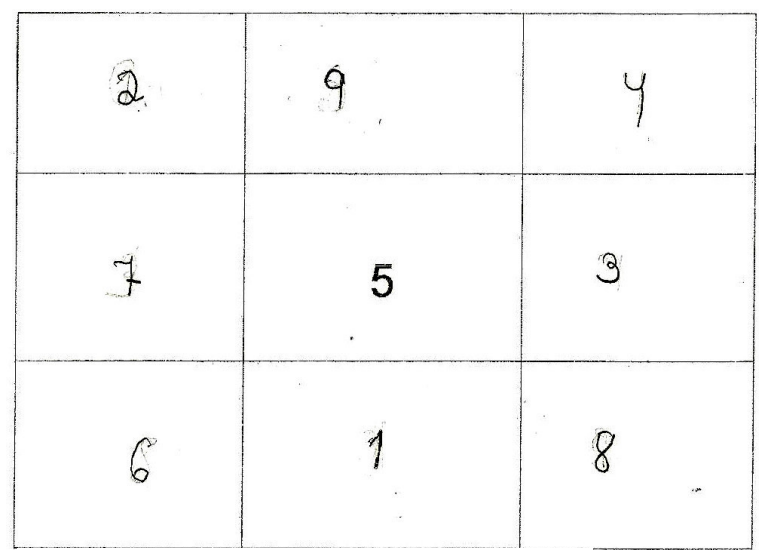

Fonte: Arquivo pessoal.

Nota-se a partir dos registros deste desafio como cada grupo pensou para organizar a sequência dos números para alcançar a soma igual a 15 nas horizontais, verticais e diagonais dos "Quadrados Mágicos". O importante foi que, ao final da discussão, todos observaram que as características das respostas são: o número 5 ocupa o centro do quadrado e, uma vez que esse número esteja colocado, os outros se encaixam; os números pares ocupam os cantos do quadrado e os ímpares estão nas casas intermediárias.

O segundo desafio proposto aos estudantes dos $5^{\text {os }}$ Anos, cujo objetivo também foi apresentar uma recreação numérica de Malba Tahan, foi feito individualmente, porém, cada membro dos grupos interativos ajudou o colega a chegar à resposta adequada. $\mathrm{O}$ desafio da "Adivinhação" (TAHAN, 1961. p. 218 e 219) ensina a calcular a idade de uma pessoa e o mês em que essa pessoa nasceu mediante um artifício muito simples. Logo abaixo, temos um exemplo das resoluções dos alunos, apresentado na Figura 15: 
Figura 15 - Resolução do desafio matemático “Adivinhação”, da estudante 1, do Grupo Interativo I (Turma 1).

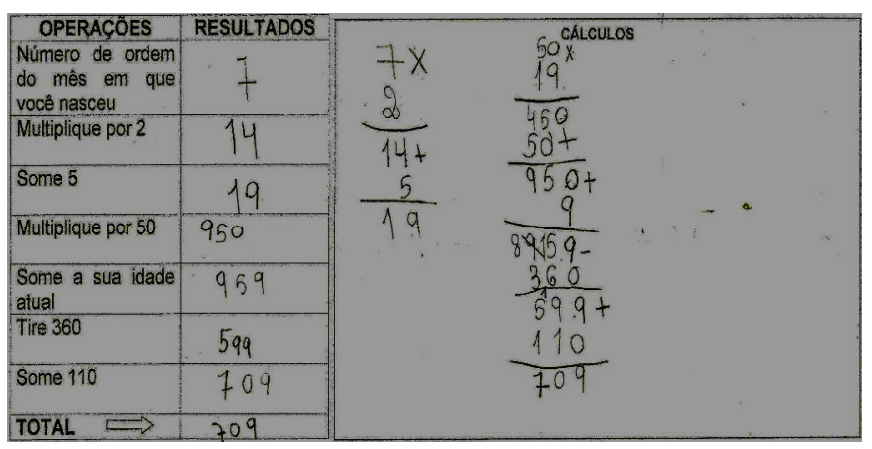

Fonte: Arquivo pessoal.

No próximo encontro, os estudantes dos grupos interativos fizeram a leitura de dois artigos de Malba Tahan: "A origem da Geometria" (1960, p. 123 a 125) do Livro Antologia da Matemática, e "Um polígono na poesia" (1962, p. 57 e 58), do Livro Matemática Divertida e Delirante. Ambos estão no Anexo E deste trabalho.

O desafio matemático do dia, “A história do Tangram” foi referente ao Eixo Espaço e Forma. Os estudantes assistiram ao vídeo que conta a história no Laboratório de Matemática e construíram o próprio Tangram e figuras, nomeando as sete peças. Utilizaram papéis coloridos, canetinha, tesoura e cola. Nesta atividade foi colocada em evidência mais uma vez a presença do diálogo e da interação entre os membros dos grupos interativos.

Foram selecionados alguns exemplos do resultado deste desafio matemático, apresentados nas Figuras 16 e 17:

Figura 16 - Resultado do desafio matemático "Tangram" da estudante 2 (Turma 1)

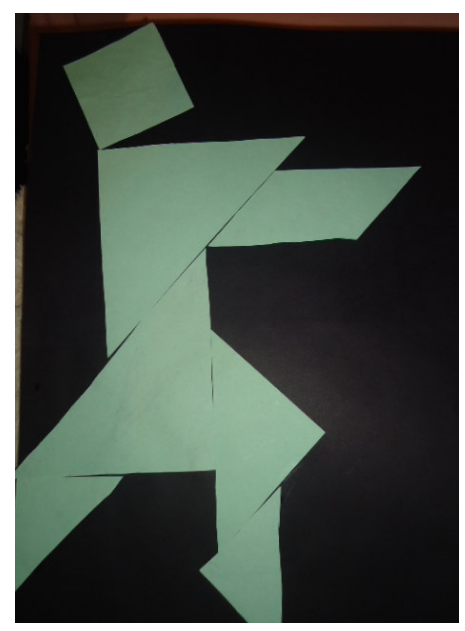

Fonte: Arquivo pessoal.
Figura 17 - Resultado do desafio matemático "Tangram" da estudante 3 (Turma 3)

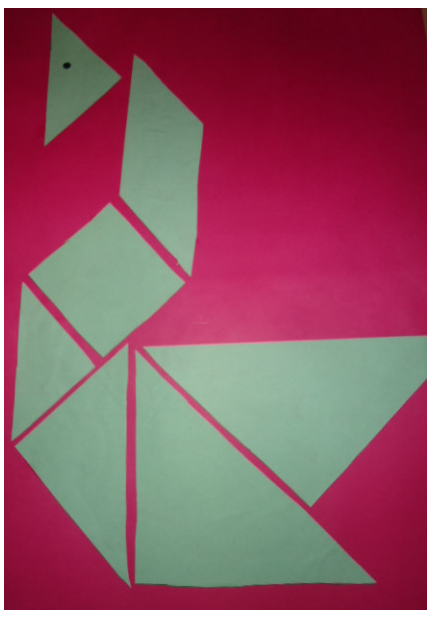

Fonte: Arquivo pessoal. 
O encontro seguinte aconteceu no Laboratório de Matemática, local organizado com mesas redondas, que facilitam a realização de trabalhos em grupo, e foi apresentado e lido o artigo "As medidas de tempo na roça e na cidade" (1998, p. 134-142), da obra "Meu Anel de Sete Pedras", de Malba Tahan e escrita em 1955 (Anexo F).

Para a realização do desafio matemático deste dia: "Memória dos relógios analógico e digital" (Anexo G), utilizamos dois espaços diferentes do Colégio: o Salão Social e o Espaço Social I, locais amplos que possibilitam os estudantes se sentarem no chão para realizar o jogo em pares. As fichas do jogo foram recortadas pelos estudantes e organizadas em um envelope. É importante destacar que, apesar da "medida de tempo" constar no rol dos conteúdos trabalhados nos livros da Rede Salesiana de Escolas (RSE) nos anos anteriores do EFI, os alunos dos $5^{\text {os }}$ Anos ainda apresentam certa dificuldade para verificar o horário no relógio analógico, já que o digital predomina no dia a dia (computador, celular, tablet)... Fazer a correspondência entre os dois tipos de relógios é um desafio e, por isso, o jogo foi pertinente para esta etapa.

Os Parâmetros Curriculares Nacionais de Matemática (BRASIL, 1997, p. 35-36) consideram que, além do jogo ser considerado um objeto sociocultural, quando realizado em grupo representa uma conquista cognitiva, emocional, moral e social para a criança e um estímulo para o desenvolvimento do seu raciocínio lógico.

Nesse caminho, Smole, Diniz e Milani (2007, p. 10) explicam que o planejamento, a busca por melhores jogadas e a utilização de conhecimentos adquiridos anteriormente propiciam o surgimento de novas ideias, a aquisição de novos conhecimentos e a possibilidade de descobrir onde estão as falhas e onde está o sucesso, permitindo compreender o próprio processo de aprendizagem e desenvolver a autonomia para continuar aprendendo.

Para finalizar esta primeira etapa, foram apresentados e lidos os fragmentos do artigo "Dez, o número universal" (Anexo H), de Malba Tahan. (1998, p. 304 a 313), da obra "Os números governam o mundo", escrito em 1965.

O desafio matemático deste encontro foi "O Jogo do Dez", que propunha a soma e a subtração dos números a partir do lançamento de três dados.

Segue um exemplo do registro do resultado de um grupo interativo, na Figura 18: 
Figura 18 - Resultado do desafio matemático "Jogo do Dez", do Grupo Interativo III, Turma 1.

\begin{tabular}{|c|c|c|c|c|c|c|c|}
\hline \multirow{2}{*}{ RODADAS } & $\begin{array}{c}\text { SOMA DOS } \\
\text { DOIS DADOS }\end{array}$ & $\begin{array}{c}\text { QUANTO } \\
\text { FALTA PARA } \\
10 ?\end{array}$ & $\begin{array}{c}\text { QUANTO } \\
\text { PASSOU DE } \\
10 ?\end{array}$ & $\begin{array}{c}\text { RESULTADO } \\
\text { DO 30 DADO? }\end{array}$ & $\begin{array}{c}\text { QUANTO } \\
\text { FALTA PARA } \\
10 ?\end{array}$ & $\begin{array}{c}\text { QUANTO } \\
\text { PASSOU DE } \\
10 ?\end{array}$ \\
\hline $1^{\mathrm{a}}$ & $5+6=11$ & 0 & 1 & 2 & 13 & 0 & 3 \\
\hline $2^{\mathrm{a}}$ & $2+2=4$ & 6 & 0 & 4 & 8 & 2 & 0 \\
\hline $3^{\mathrm{a}}$ & $4+5=9$ & 2 & 0 & 1 & 10 & 0 & 0 \\
\hline $4^{\mathrm{a}}$ & $5+1=6$ & 4 & 0 & 2 & 8 & 2 & 0 \\
\hline $5^{\mathrm{a}}$ & $2+3=5$ & 5 & 0 & 3 & 8 & 2 & 0 \\
\hline
\end{tabular}

Fonte: Arquivo pessoal.

Em sequência, a Etapa II foi planejada e realizada como mostra o Quadro 14:

Quadro 14 - Plano de Ação da Etapa II: Construção do Almanaque Malbatahânico

\begin{tabular}{|c|c|c|c|c|c|}
\hline Quando? & O quê? & Como? & Quem? & Onde? & Para quê? \\
\hline $\begin{array}{c}3^{\mathrm{a}} \text { aula } \\
50 \text { minutos }\end{array}$ & $\begin{array}{l}\text { Construção do } \\
\text { Almanaque } \\
\text { Malbatahânico. }\end{array}$ & $\begin{array}{l}\text { Apresentação de diferentes } \\
\text { tipos de almanaques e } \\
\text { pesquisa da vida e obra de } \\
\text { Malba Tahan } \\
\text { - Autódromo da biografia de } \\
\text { Malba Tahan - }\end{array}$ & $\begin{array}{c}\text { Pesquisadora, } \\
\text { Bibliotecária, } \\
\text { Prof a da classe e } \\
\text { Estudantes dos } 5^{\text {os }} \\
\text { Anos }\end{array}$ & Biblioteca & $\begin{array}{c}\text { Pesquisar a biografia de Malba } \\
\text { Tahan }\end{array}$ \\
\hline $\begin{array}{c}3^{\mathrm{a}} \text { aula } \\
50 \text { minutos }\end{array}$ & $\begin{array}{l}\text { Construção do } \\
\text { Almanaque } \\
\text { Malbatahânico. }\end{array}$ & $\begin{array}{c}\text { Dramatização pela } \\
\text { pesquisadora do conto “A } \\
\text { glória do sapo" (Anexo I). } \\
\text { Elaboração de uma } \\
\text { mensagem e uma ilustração } \\
\text { do conto por cada grupo } \\
\text { interativo. } \\
\text { Pesquisa de um conto de } \\
\text { Malba Tahan }\end{array}$ & $\begin{array}{c}\text { Pesquisadora, } \\
\text { Bibliotecária, } \\
\text { Prof da classe e } \\
\text { Estudantes dos } 5^{\text {os }} \\
\text { Anos }\end{array}$ & Biblioteca & $\begin{array}{c}\text { Ouvir, analisar e escolher em } \\
\text { equipe uma mensagem para o conto } \\
\text { "A glória do sapo", de Malba } \\
\text { Tahan. } \\
\text { Pesquisar, ler e selecionar alguns } \\
\text { contos de Malba Tahan. }\end{array}$ \\
\hline $\begin{array}{c}3^{\mathrm{a}} \text { aula } \\
50 \text { minutos }\end{array}$ & $\begin{array}{l}\text { Construção do } \\
\text { Almanaque } \\
\text { Malbatahânico. }\end{array}$ & $\begin{array}{c}\text { Partilha da pesquisa: conto. } \\
\text { Pesquisa de uma } \\
\text { comida árabe }\end{array}$ & $\begin{array}{c}\text { Pesquisadora, } \\
\text { Bibliotecária, } \\
\text { Prof da classe e } \\
\text { Estudantes dos } 5^{\text {os }} \\
\text { Anos } \\
\end{array}$ & Biblioteca & $\begin{array}{c}\text { Partilhar a pesquisa. } \\
\text { Pesquisar, ler selecionar receitas da } \\
\text { Culinária Árabe }\end{array}$ \\
\hline $\begin{array}{c}3^{\mathrm{a}} \text { aula } \\
50 \text { minutos }\end{array}$ & $\begin{array}{l}\text { - Construção do } \\
\text { Almanaque } \\
\text { Malbatahânico. } \\
\text { - Encerramento da } \\
\text { etapa com a } \\
\text { produção do } \\
\text { Almanaque } \\
\text { Malbatahânico. }\end{array}$ & $\begin{array}{l}\text { Ler o artigo "Unidades } \\
\text { curiosas na arte culinária } \\
\text { brasileira" (Anexo J) e } \\
\text { selecionar quais farão parte } \\
\text { do Almanaque (p. } 108 \text { a } \\
\text { 121); Livro Meu Anel de } \\
\text { Sete Pedras. }\end{array}$ & $\begin{array}{c}\text { Pesquisadora, } \\
\text { Bibliotecária, } \\
\text { Prof a da classe e } \\
\text { Estudantes dos } 5^{\text {os }} \\
\text { Anos }\end{array}$ & Biblioteca & $\begin{array}{c}\text { Partilhar a pesquisa. } \\
\text { - Ler, selecionar e comparar as } \\
\text { unidades curiosas na arte Culinária } \\
\text { Brasileira. }\end{array}$ \\
\hline
\end{tabular}

Fonte: autoria própria.

No primeiro encontro desta etapa foram apresentados diferentes tipos de almanaques $^{7}$ na Biblioteca do Colégio do Carmo, selecionados pela bibliotecária, antecipadamente. Após os grupos interativos analisarem cada um deles, realizamos um

\footnotetext{
${ }^{7}$ Alguns almanaques selecionados e disponíveis na biblioteca do INSC: Almanaque Ruth Rocha, Almanaque Recreio, Almanaque Abril, Almanaque Animais do Brasil, Almanaque do Menino Maluquinho, Almanaque das Curiosidades Matemáticas, Almanaque Globo Rural, etc.
} 
jogo chamado "Autódromo" (Apêndice B), para relembrarmos a biografia de Malba Tahan. Este jogo teve 10 alternativas e cada uma delas apresentou duas afirmativas que poderiam ser: Verdadeira e Verdadeira (VV), Falsa e Falsa (FF), Verdadeira e Falsa (VF) ou Falsa e Verdadeira (FV). A pesquisadora leu em voz alta somente uma vez cada alternativa para os grupos interativos, pois uma das regras do jogo era que a leitura não poderia ser repetida, exigindo assim maior concentração da turma. Após um minuto, o líder de cada grupo interativo mostrava a placa com a resposta escolhida e a Professora de Língua Portuguesa, anotava o resultado em uma tabela para ter o controle de qual grupo seria vencedor no final do jogo.

Os resultados do jogo "Autódromo" (Apêndices C e D) também podem ser conferidos nas próximas figuras 19 e 20 :

Figuras 19 e 20 - Gráficos dos resultados do jogo "Autódromo" da biografia de Malba Tahan dos Grupos Interativos (Turmas 1 e 2).


Fonte: Arquivo pessoal.

Notemos na Figura 19, então, que os Grupos Interativos II e V da Turma 1, acertaram o maior número de alternativas, por se concentrarem melhor durante o jogo, por compreenderem o que havia sido lido pela pesquisadora e por terem se lembrado dos fatos contados sobre a vida de Malba Tahan durante o "Boa Tarde" motivacional. Enquanto que, como mostra a Figura 20, na Turma 2, os Grupos Interativos que alcançaram o maior número de acertos referentes à biografia de Malba Tahan foram: I e III.

Em outro encontro, nos reunimos novamente na Biblioteca do Colégio. Neste dia, a pesquisadora encenou o conto "A glória do sapo" (TAHAN, 1966, p. 134-137, Anexo I), com a participação dos estudantes e da Professora de Língua Portuguesa. 
Em seguida, com o intuito dos estudantes refletirem sobre o conto de Malba Tahan, foi proposta uma atividade em que cada Grupo Interativo teria que elaborar uma mensagem e uma ilustração do conto. Segue um exemplo de registro, na Figura 21:

Figura 21 - Mensagem e ilustração elaboradas pelo Grupo Interativo I sobre o conto "A glória do sapo" (Turma 1)
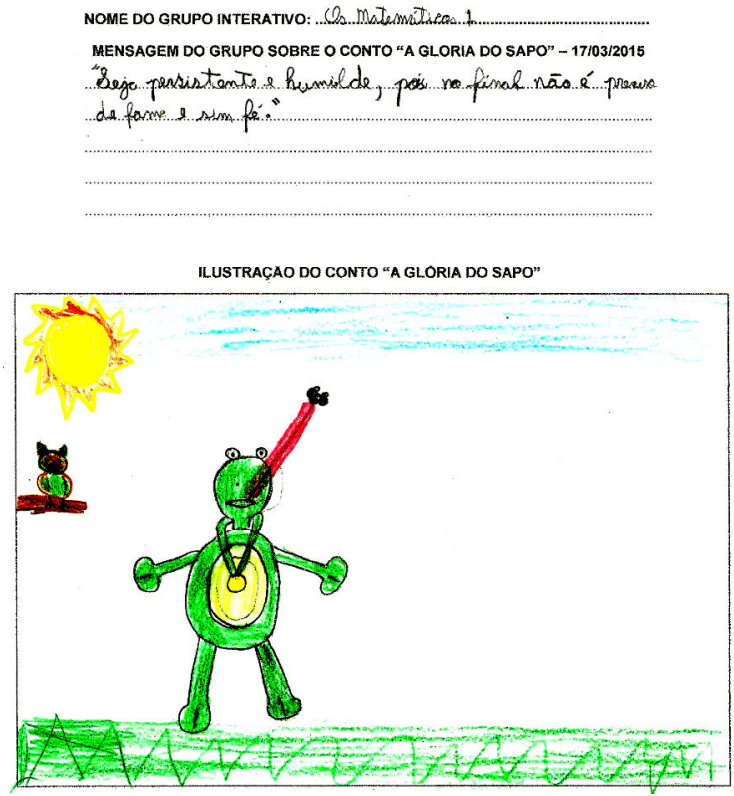

Fonte: Arquivo pessoal.

Para finalizar este encontro, a pesquisadora solicitou que os estudantes pesquisassem em casa ou na Biblioteca do Colégio um conto de Malba Tahan. Assim, no encontro seguinte, todos fizeram a partilha dos contos pesquisados. A seguir, o Quadro 15 apresenta a lista dos títulos trazidos pelos alunos:

Quadro 15 - Lista dos títulos dos contos de Malba Tahan pesquisados pelos estudantes dos $5^{\text {os }}$ Anos

\begin{tabular}{|l|l|}
\hline O gato do Cheique & O Sábio da Efelogia \\
\hline Os 35 camelos & Lendas do deserto \\
\hline A história da onça que queria acordar cedo & O mercador de sonhos \\
\hline A pequenina luz azul & O problema das oito caixas \\
\hline O rabi e o cocheiro & O Livro do Destino \\
\hline Os sonhos do lenhador & Os Três Homens Iguais \\
\hline Os dois amigos & Lenda árabe \\
\hline Dez anos de Kest & A noiva de Romaina \\
\hline Os cegos e o elefante & O Homem que Calculava \\
\hline
\end{tabular}

Fonte: Arquivo pessoal. 
Após a partilha da pesquisa, os educandos conversaram e decidiram qual conto seria analisado pelo Grupo Interativo. Logo, segue um exemplo de registro realizado por eles, na Figura 22:

Figura 22 - Análise do conto "O homem que calculava", feita pela estudante 4 do Grupo Interativo V, Turma 1.

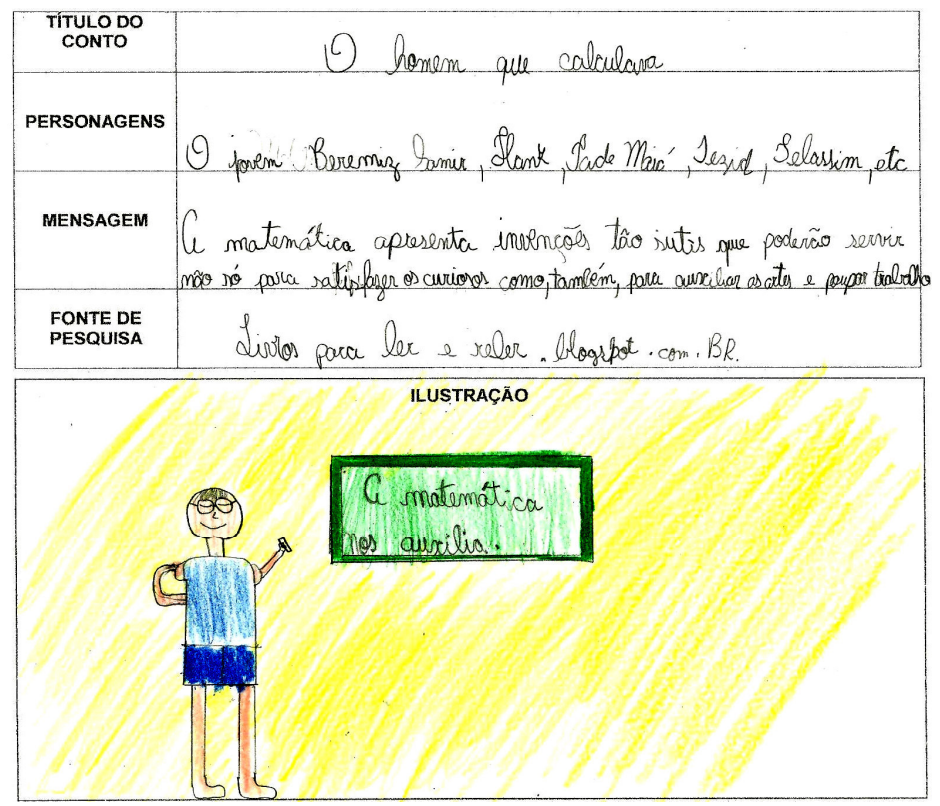

Fonte: Arquivo pessoal.

Observando a análise da estudante 4, é admirável notar como a Matemática nos contos de Malba Tahan "brilha" e como crianças entre 9 e 10 anos interpretam e reconhecem a sua importância a partir da leitura de uma história. A aluna também buscou o pensamento de Descartes para explicar a mensagem da obra "O Homem que Calculava" de Malba Tahan.

Finalizando este encontro, novamente foi proposta outra pesquisa para os alunos: uma receita da culinária árabe.

Logo, na próxima aula, todos apresentaram suas pesquisas, que foram realizadas em casa. Muitos estudantes buscaram os conhecimentos culinários de seus pais e avós; outros pesquisaram na internet. $\mathrm{O}$ objetivo desta atividade foi pesquisar, ler e comparar as unidades de medidas nas receitas culinárias que pesquisaram com o artigo "Unidades curiosas na arte culinária brasileira" (TAHAN, 1998, p. 108-121 Anexo J), do livro "Meu Anel de Sete Pedras", escrito em 1955. Apesar de algumas receitas pesquisadas pelos estudantes não terem, de fato, origem árabe, todas foram utilizadas na atividade. Os nomes das receitas foram listados a seguir, no Quadro 16: 
Quadro 16 - Lista dos nomes das receitas da culinária árabe pesquisadas pelos estudantes

\begin{tabular}{|l|l|}
\hline $\begin{array}{l}\text { Esfiha de Toscana; Esfiha de carne com } \\
\text { pimenta }\end{array}$ & Tabule com alho poro \\
\hline Kibe de carne & Beirute de rosbife \\
\hline Falafel & Kibe cru \\
\hline Bolo de coalhada & Kafka de cordeiro; Kafka no espeto \\
\hline Sopa de lentilhas & Charuto de repolho \\
\hline Batata recheada & Cuscuz marroquino com castanha de caju \\
\hline Pão árabe & Basbousa de leite condensado \\
\hline Coxinha árabe de frango & Burma \\
\hline Lanche Frescor das Arábias & Doce sírio de macarrão e nozes \\
\hline
\end{tabular}

Fonte: Arquivo pessoal.

A Professora de Matemática, que leciona há 45 anos, contribuiu com um comentário muito pertinente no momento em que estávamos desenvolvendo esta proposta: "Nós utilizamos no dia a dia a linguagem matemática sem perceber. As unidades de medidas podem ser representadas de diversas formas, até mesmo nas expressões 'montinho', 'colherinha', 'punhado'... como escreveu Malba Tahan. Minha avó já dizia isto há muitos anos e fazia Matemática na cozinha sem saber.”

Caminhamos, então, para a Etapa III do Plano de Ação desta pesquisa, que contemplou os jogos dramáticos ou jogos teatrais a partir dos contos de Malba Tahan. Ela foi organizada conforme mostra o Quadro 17:

Quadro 17 - Plano de Ação da Etapa III: Jogos Dramáticos com os contos de Malba Tahan

\begin{tabular}{|c|c|c|c|c|c|}
\hline Quando? & O quê? & Como? & Quem? & Onde? & Para quê? \\
\hline $\begin{array}{l}3^{\mathrm{a}} \text { aula } \\
50 \\
\text { minutos }\end{array}$ & $\begin{array}{l}\text { Organização } \\
\text { para a } \\
\text { dramatização } \\
\text { de uma } \\
\text { história de } \\
\text { Malba Tahan. }\end{array}$ & $\begin{array}{l}\text { Sorteio da história e planejamento: } \\
\text { cenário, personagens e vestimentas. } \\
\text { Histórias: } \\
\text { 1- "O nariz do Rei Mahendra" (p. } 31 \text { a } \\
\text { 34, Anexo K); Livro Maktub. } \\
\text { 2- "O homem Maravilhoso" (p. } 103 \text { a } \\
\text { 106, Anexo L); Livro Maktub. } \\
\text { 3- "O colecionador de coincidências" } \\
\text { (p. } 71 \text { a 76, Anexo M); Livro Maktub. } \\
\text { 4- "O vendedor de conselhos" (p. } 48 \text { a } \\
\text { 54, Anexo N); Livro Maktub. } \\
\text { 5- "O problema dos } 35 \text { camelos" (p. } \\
\text { 17 a 19, Anexo O); Livro Antologia } \\
\text { da Matemática (1 } 1^{\circ} \text { ) }\end{array}$ & $\begin{array}{l}\text { Pesquisadora, } \\
\text { Prof. de } \\
\text { Arte/Musicaliza } \\
\text { ção, Prof }{ }^{\text {a da }} \\
\text { classe e } \\
\text { Estudantes dos } \\
5^{\text {os }} \text { Anos }\end{array}$ & $\begin{array}{l}\text { Laboratório de } \\
\text { Matemática }\end{array}$ & $\begin{array}{c}\text { Explorar as diferentes formas de } \\
\text { se expressar a partir de } \\
\text { encenações das situações- } \\
\text { problema e/ou histórias de Malba } \\
\text { Tahan. }\end{array}$ \\
\hline $\begin{array}{l}3^{\mathrm{a}} \text { aula } \\
50 \\
\text { minutos }\end{array}$ & $\begin{array}{c}\text { Apresentação } \\
\text { da } \\
\text { dramatização } \\
\text { de uma } \\
\text { história de } \\
\text { Malba Tahan. }\end{array}$ & $\begin{array}{l}\text { Apresentar para os colegas de turma e } \\
\text { para os professores a dramatização de } \\
\text { uma história de Malba Tahan. }\end{array}$ & $\begin{array}{l}\text { Pesquisadora, } \\
\text { Prof. de } \\
\text { Arte/Musicaliza } \\
\text { ção, Prof }{ }^{\text {a }} \text { da } \\
\text { classe e } \\
\text { Estudantes dos } \\
5^{\text {os }} \text { Anos }\end{array}$ & Salão Social & $\begin{array}{l}\text { Avaliar a desenvoltura para } \\
\text { caracterizar um personagem } \\
\text { (expressão oral e corporal), a } \\
\text { utilização de diferentes } \\
\text { recursos/materiais e objetos de } \\
\text { encenação, (Continua) }\end{array}$ \\
\hline
\end{tabular}




\begin{tabular}{|c|c|c|c|c|c|}
\hline Quando? & O quê? & Como? & Quem? & Onde? & Para quê? \\
\hline & & & & & $\begin{array}{c}\text { (Continuação) a originalidade de } \\
\text { ideias, a criatividade, a } \\
\text { organização/preparação do } \\
\text { cenário, a ampliação dos } \\
\text { conhecimentos matemáticos e o } \\
\text { trabalho em equipe. }\end{array}$ \\
\hline $\begin{array}{l}3^{\mathrm{a}} \text { aula } \\
50 \\
\text { minutos }\end{array}$ & $\begin{array}{c}\text { Apresentação } \\
\text { da } \\
\text { dramatização } \\
\text { de uma } \\
\text { história de } \\
\text { Malba Tahan }\end{array}$ & $\begin{array}{c}\text { Apresentar para os colegas de turma e } \\
\text { para os professores a dramatização de } \\
\text { uma história de Malba Tahan. }\end{array}$ & $\begin{array}{l}\text { Pesquisadora, } \\
\text { Prof. de } \\
\text { Arte/Musicaliza } \\
\text { ção, Prof }{ }^{\mathrm{a}} \text { da } \\
\text { classe e } \\
\text { Estudantes dos } \\
5^{\text {os }} \text { Anos }\end{array}$ & Salão Social & $\begin{array}{c}\text { Avaliar a desenvoltura para } \\
\text { caracterizar um personagem } \\
\text { (expressão oral e corporal), a } \\
\text { utilização de diferentes } \\
\text { recursos/materiais e objetos de } \\
\text { encenação, a originalidade de } \\
\text { ideias, a criatividade, a } \\
\text { organização/preparação do } \\
\text { cenário, a ampliação dos } \\
\text { conhecimentos matemáticos e o } \\
\text { trabalho em equipe. }\end{array}$ \\
\hline $\begin{array}{l}3^{\mathrm{a}} \text { aula } \\
50 \\
\text { minutos }\end{array}$ & $\begin{array}{l}\text { Avaliação } \\
\text { Diagnóstica } \\
\text { Livro de } \\
\text { Poemas } \\
\text { Malbatahânic } \\
\text { os }\end{array}$ & $\begin{array}{l}\text { Avaliação Diagnóstica Final com } \\
\text { questões contemplando os quatro } \\
\text { eixos da Matemática. } \\
\text { Escrita de Poema }\end{array}$ & $\begin{array}{l}\text { Pesquisadora, } \\
\text { Prof }{ }^{\mathrm{a}} \text { da classe e } \\
\text { Estudantes dos } \\
5^{\text {os }} \text { Anos }\end{array}$ & Classe & $\begin{array}{c}\text { Avaliar os conhecimentos } \\
\text { adquiridos durante as etapas } \\
\text { do projeto de pesquisa. } \\
\text { Autoavaliação a partir da } \\
\text { escrita de poemas. }\end{array}$ \\
\hline
\end{tabular}

Fonte: autoria própria.

O planejamento da Etapa III, além de ter sido inspirado pela prática educativa de Malba Tahan, também buscou na proposta metodológica de ensino de teatro de Viola Spolin (1906-1994) uma orientação para conduzir os encontros. De acordo com Japiassu (2012, p. 41), o sistema de jogos teatrais desta atriz, professora e diretora de teatro norteamericana foi particularmente difundido a partir dos anos 60. Spolin enfatizou a dimensão improvisacional do fazer teatral e destacou a importância das interações intersubjetivas na construção do sentido da representação cênica.

Spolin experimentou seu método com estudantes e profissionais de teatro, com professores e alunos do ensino fundamental e médio, em programas educacionais de crianças portadoras de necessidades especiais, em cursos para o estudo de idiomas, religião, psicologia e em centros de reabilitação de crianças delinquentes. Constatou que seu sistema de jogos teatrais era um processo aplicável a qualquer campo, disciplina ou assunto por "possibilitar um espaço possível para interação e comunicação verdadeiras entre sujeitos”. A proposta metodológica de Viola Spolin, embora originalmente voltada para o ensino de teatro (de uma perspectiva pedagógica essencialista ou estética), não exclui a possibilidade de seu uso instrumental em diferentes áreas de aplicação. [...] A proposta spoliana de ensino de teatro tem sido investigada exaustivamente no Brasil pelo grupo de pesquisadores em teatro e educação da USP, sob liderança das professoras Ingrid D. Koudela e Maria Lúcia de S. B. Pupo (Pupo, 1991, 1997). [...] (JAPIASSU, 2012, p. 42)

À luz deste enfoque interdisciplinar, iniciamos os encontros da Etapa III. Neste dia, realizamos o sorteio dos contos previamente selecionados pela pesquisadora, como mostra o Quadro 18. Assim, cada Grupo Interativo pode iniciar o planejamento e os ensaios para a dramatização. O objetivo da proposta foi resgatar os contos de Malba Tahan para o 
desenvolvimento cultural, para a interpretação de textos dramáticos, para a resolução de situações-problema e para o crescimento pessoal dos educandos, pela fluência, pela decodificação, pelo domínio e pela leitura crítica da linguagem teatral.

Quadro 18 - Contos de Malba Tahan sorteados para a dramatização

\begin{tabular}{|c|l|l|}
\hline Conto & \multicolumn{1}{|c|}{ TURMA 1 } & \multicolumn{1}{c|}{ TURMA II } \\
\hline O nariz do Rei Mahendra. & I - Os Matemáticos I & I - Os Sábios da Matemática \\
\hline O homem maravilhoso. & II - Os Matemáticos III & II - As fórmulas \\
\hline O colecionador de coincidências. & III - Os Divisores & III - Adição \\
\hline O vendedor de conselhos. & IV - Os Matemáticos II & IV - Subtração \\
\hline O problema dos 35 camelos. & V - Os Multiplicadores & V - Divisão \\
\hline
\end{tabular}

Fonte: autoria própria.

Os estudantes receberam os textos narrativos e também a adaptação para o texto teatral, feita pela pesquisadora pelo fato dos textos serem longos, para fazer a leitura e a seleção dos personagens do conto, além de planejarem também a caracterização de cada um e o que precisariam providenciar para o cenário e trilha sonora ${ }^{8}$.

Os próximos encontros, realizados para os ensaios e apresentações das dramatizações foram estruturados e realizados em torno das seguintes noções, segundo Japiassu (2012, p. 70): QUE (ação do jogo teatral), ONDE (espaço ou lugar da ação no jogo teatral) e QUEM (papéis do jogo teatral). Essas noções compõem os principais fundamentos para a instalação da realidade cênica. Apesar do número reduzido de encontros na Etapa III, os jogos teatrais seguiram uma determinada rotina:

1) Formação do círculo de discussão;

2) Divisão do grupo em equipes;

3) Prática de jogos tradicionais infantis, nos quais podem ser destacados aspectos originais de teatralidade;

4) Avaliação coletiva imediatamente após a apresentação de cada uma das equipes na área de jogo;

5) Prática de jogos teatrais propriamente ditos - direcionados para a apropriação de conceitos teatrais muito precisos;

6) Avaliação coletiva ao fim das atividades desenvolvidas durante a sessão de trabalho, retomando-se o círculo de discussão. (JAPIASSU, 2012, P. 71)

Para inaugurar cada sessão de encontro com os jogos teatrais dos contos de Malba Tahan fazíamos o círculo de discussão no Salão Social do Colégio, onde aconteciam os ensaios. Nele, a pesquisadora relembrava os encontros anteriores e discutia as descobertas

\footnotetext{
${ }^{8}$ Os estudantes contaram com o apoio do Professor de Musicalização para a escolha da trilha sonora dos contos de Malba Tahan.
} 
realizadas pelos Grupos Interativos. Também era o momento em que avisos, combinados, e acontecimentos referentes ao trabalho eram partilhados. O círculo funcionou como uma preparação/concentração para a "passagem" da realidade concreta à realidade cênica ou simbólica, além de constituir um espaço privilegiado de reflexão sobre a práxis dos grupos.

Durante as dramatizações dos contos de Malba Tahan, a pesquisadora observou e avaliou a participação dos estudantes, o processo de aquisição, fluência e domínio da linguagem teatral por parte dos estudantes baseado em critérios objetivos. Neste caso, a avaliação dos encontros da Etapa III teve caráter qualitativo, sendo possível estabelecer uma reflexão crítica constante sobre a prática e também o redirecionamento dessa prática.

É preciso esclarecer que para ocorrer o desenvolvimento ideal de uma representação cênica demandaria mais tempo aos Grupos Interativos do que o planejado pela pesquisadora. Por este motivo, o ritmo de aprendizado e o desempenho individual e coletivo dos estudantes neste curto período foram levados em consideração. Outro fato que necessita de explicação é que a pesquisadora não teve a intenção de preparar os alunos para uma montagem teatral, embora isto seja possível com mais tempo de ensaios e preparação.

Em sequência, foi aplicada a Avaliação Diagnóstica Final de Matemática (Anexo P), cujas questões também tiveram como referência a prova do SARESP e da SAEB/Prova Brasil, contemplando os quatro Eixos propostos pelos Parâmetros Curriculares Nacionais, com o objetivo de verificar os avanços e as possíveis dificuldades dos estudantes neste período do ano letivo, após o desenvolvimento de todas as etapas do Plano de Ação da pesquisa. O Quadro 19 apresenta os Eixos e os Descritores das questões da Avaliação Diagnóstica Final de Matemática:

Quadro 19 - Eixos e Descritores das Questões do Pós-Teste de Matemática

\begin{tabular}{|l|c|l|}
\hline Questões & Eixo & \multicolumn{1}{c|}{ Descritores } \\
\hline Questão 1 & Espaço e Forma & $\begin{array}{l}\text { 3. Identificar propriedades comuns e diferenças entre figuras } \\
\text { bidimensionais pelo número de lados, pelos tipos de ângulos. }\end{array}$ \\
\hline Questão 2 & Números e Operações & $\begin{array}{l}\text { 17. Calcular o resultado de uma adição ou subtração de números } \\
\text { naturais. }\end{array}$ \\
\hline Questão 3 & Números e Operações & $\begin{array}{l}\text { 13. Reconhecer e utilizar características do sistema de } \\
\text { numeração decimal, tais como agrupamentos e trocas na base 10 } \\
\text { e princípio do valor posicional. }\end{array}$ \\
\hline Questão 4 & Espaço e Forma & $\begin{array}{l}\text { 1. Identificar a localização e movimentação de objeto em } \\
\text { mapas, croquis e outras representações gráficas. }\end{array}$ \\
\hline Questão 5 & Espaço e Forma & $\begin{array}{l}\text { 4. Identificar quadriláteros observando as posições relativas } \\
\text { entre seus lados (paralelos, concorrentes, perpendiculares). }\end{array}$ \\
\hline Questão 6 & Grandezas e Medidas & $\begin{array}{l}\text { 9. Estabelecer relações entre o horário de início e término e/ou o } \\
\text { intervalo da duração de um evento ou acontecimento. }\end{array}$ \\
\hline Questão 7 & Grandezas e Medidas & \begin{tabular}{l} 
8. Estabelecer relações entre unidades de medida de tempo. \\
\hline Questão 8
\end{tabular} Tratamento de \\
Informação & $\begin{array}{l}\text { 28. Ler informações e dados apresentados em gráficos } \\
\text { (particularmente em gráficos de colunas). (Continua) }\end{array}$ \\
\hline
\end{tabular}




\begin{tabular}{|l|l|l|}
\hline Questão 9 & Grandezas e Medidas & $\begin{array}{l}\text { (Continuação) 9. Estabelecer relações entre o horário de início e } \\
\text { término e/ou o intervalo da duração de um evento ou } \\
\text { acontecimento. }\end{array}$ \\
\hline Questão 10 & Números e Operações & $\begin{array}{l}\text { 19. Resolver problema com números naturais, envolvendo } \\
\text { diferentes significados da adição ou subtração: juntar, alteração } \\
\text { de um estado inicial (positiva ou negativa), comparação e mais } \\
\text { de uma transformação (positiva ou negativa). }\end{array}$ \\
\hline
\end{tabular}

Fonte: Matriz de Referência de Matemática do $5^{\circ}$ ano do EFI, INEP. Acesso em 20 de janeiro de 2015.

Com o auxílio das próximas figuras, é possível fazer uma análise do desempenho de cada turma:

Figura 23 - Gráfico do resultado da Avaliação Diagnóstica Final da Turma 1.

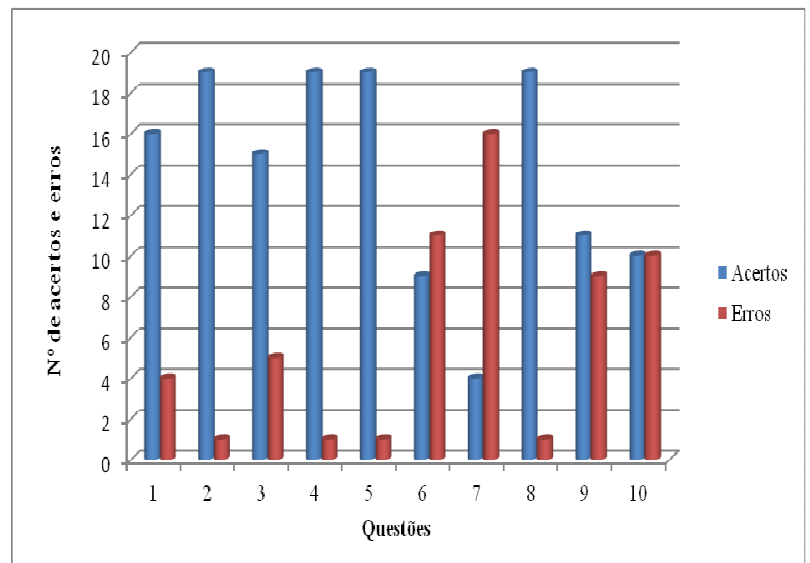

Fonte: Arquivo pessoal.
Figura 24 - Gráfico do resultado da Avaliação Diagnóstica Final da Turma 2.

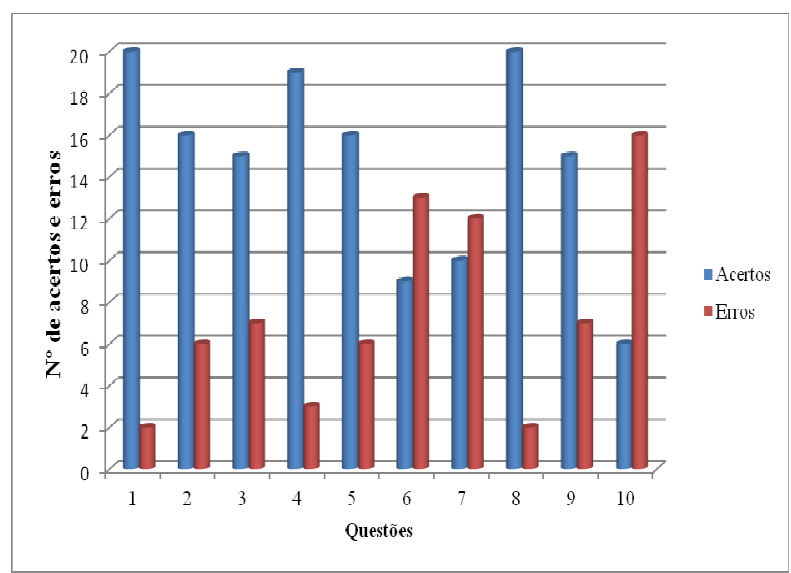

Nota-se que na Figura 23 as questões com o maior número de acertos (19) da Avaliação Diagnóstica Final realizada pelos estudantes da Turma A foram: 2, 4, 5 e 8, cujos Eixos são: Números e Operações, Espaço e Forma, Espaço e Forma e Tratamento da Informação, respectivamente. As questões 6 e 7 apresentaram maior grau de dificuldade, tratando-se do Eixo Grandezas e Medidas e dos Descritores 9 e 8 que ligados ao conteúdo "medidas de tempo". Comprova-se a necessidade de retomá-lo sistematicamente, considerando que mesmo para os estudantes dos $5^{\text {os }}$ Anos, que estudaram nos anos anteriores do EFI e ainda estudam tal conteúdo, ainda há dificuldade na resolução de situações-problema em que é necessário estabelecer relações entre o horário de início e término e/ou o intervalo da duração de um evento.

Vimos nos resultados apresentados na Figura 24 que as questões 1 e 8 atingiram o maior número de acertos (20). Tais questões se classificam nos seguintes Eixos, respectivamente: Espaço e Forma e Tratamento de Informação. Por outro lado, as questões 
com maior índice de erros foram: 6 (Grandezas e Medidas), 7 (Grandezas e Medidas) e 10 (Números e Operações).

Se compararmos as questões que os alunos apresentaram maior dificuldade de resolver, constatamos que, de fato, o Eixo Grandezas e Medidas e o conteúdo "medidas de tempo" necessitam de uma atenção especial nos próximos planejamentos das Professoras durante o $2^{\circ}$ Semestre de 2015.

Figura 25 - Gráfico dos resultados da Avaliação Diagnóstica Final de Matemática (Turmas 1 e 2).

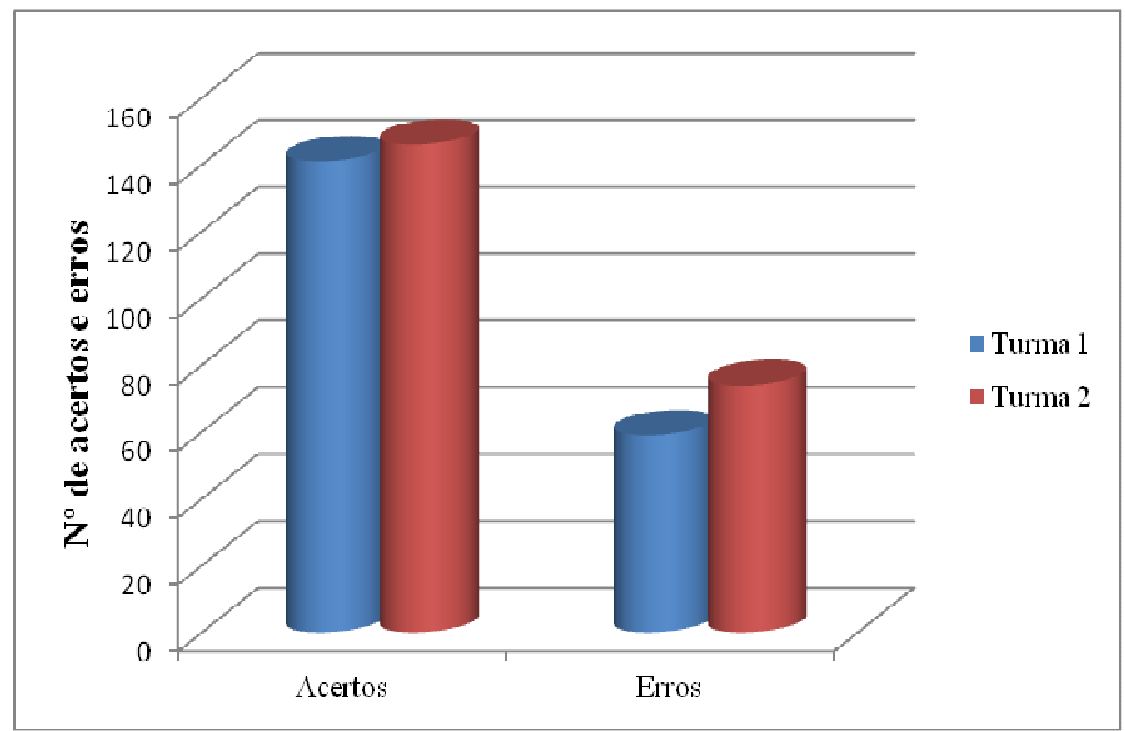

Fonte: Arquivo pessoal.

Analisando a Figura 25, mesmo com o número de alunos sendo diferente, porém próximos, percebe-se um significativo avanço na resolução de situações-problema em relação à Avaliação Diagnóstica Inicial. Ambas as turmas tiveram maior número de acertos do que de erros nas questões da Avaliação Diagnóstica Final, que apesar de não terem sido iguais às da Inicial, foram questões selecionadas das mesmas fontes: SARESP e SAEB/Prova Brasil.

\subsection{Apresentação e apreciação das vivências interdisciplinares: Matemática, Língua Portuguesa, Arte, Ciências, História e Geografia.}

A apresentação e a apreciação das atividades desenvolvidas nesta pesquisa realizaram-se em dois momentos: o primeiro durante o "Boa Tarde" especial com a visita da Inspetora Irmã Helena Gesser, da Inspetoria Santa Catarina de Sena, de São Paulo. No 
final do mês de maio de 2015, a pesquisadora apresentou para ela, para a Direção, professores (as) e estudantes do Colégio do Carmo um vídeo com as imagens das principais atividades desenvolvidas no decorrer das etapas do Plano de Ação e presenteou a Inspetora com a coletânea de "Poemas Malbatahânicos" (Anexo T), escritos pelos estudantes dos no final da Etapa III do Plano de Ação.

O segundo momento concretizou-se com uma Exposição Malbatahânica (Anexo U) sobre as etapas do projeto durante as Reuniões de Pais do $1^{\circ}$ Trimestre (EFI) e $1^{\circ}$ Semestre (EI), no mês de maio (em comemoração ao Dia Nacional da Matemática, 06 de maio) e junho de 2015. As Professoras fizeram o planejamento da exposição e a pesquisadora elaborou o convite (Apêndice E) para ser enviado aos pais/responsáveis dos educandos.

Assim, as Professoras apresentaram aos pais dos estudantes no dia da Exposição Malbatahânica e da Reunião de Pais os resultados dos trabalhos matemáticos interdisciplinares desenvolvidos.

De modo geral, os pais e responsáveis acolheram muito bem a maneira como foi organizada a Reunião de Pais e a Exposição Malbatahânica. A pesquisadora acompanhou cada turma e depois constatou pelo relatório individual escrito pelas educadoras da EI e do EFI que o retorno das famílias dos estudantes foi muito positivo, pois ficaram satisfeitas e mais confiantes com a proposta educativa realizada pela equipe do Colégio do Carmo. 


\section{REFLEXÕES FINAIS}

A principal evidência desta pesquisa foi a de que o trabalho pedagógico orientado pelos pressupostos básicos interdisciplinares a partir de Grupos Interativos utilizando a literatura de Malba Tahan favorece a aprendizagem dos estudantes. Os ganhos obtidos revelaram-se na relação à aquisição do conhecimento e, além disso, as concepções malbatahânicas estabeleceram uma mobilização interdisciplinar, no intuito de pensar, elaborar e decidir quais propostas e intervenções seriam aplicadas a partir de um trabalho interativo e dialógico da Matemática com a Literatura, assim como destas com as demais áreas do saber.

Com este trabalho também buscamos melhorias e avanços no rendimento acadêmico dos estudantes e a qualificação dos projetos interdisciplinares por meio da partilha de experiências matemáticas da equipe docente. Postas em prática, elas contribuíram para as investigações que conceberam o estudante como sujeito ativo e protagonista na construção do conhecimento, considerando as formas particulares de aprender a pensar.

A avaliação desta pesquisa foi qualitativa e quantitativa, baseada na APPD (Avaliação Psicopedagógica Dinâmica), com as observações e intervenções feitas pela pesquisadora e pelas professoras durante as atividades de cada etapa. Esta avaliação centrase num processo de interação mediatizada que visa encorajar, estimar e promover a capacidade de aprendizagem dos estudantes.

A avaliação tradicional e normalizada perspectiva aquilo que Vygotsky ${ }^{9}$ (1962, 1986 apud FONSECA, 2002, p. 19), definiu por Zona de Desenvolvimento Atual (ZDA), ou seja, o que os observados (estudantes) podem fazer no momento das atividades; em contraste, a APPD busca ir mais longe, procurando determinar o que eles podem fazer com a ajuda de um mediador (neste caso, a pesquisadora, a professora ou outro aluno), atingindo a Zona de Desenvolvimento Proximal (ZDP).

\footnotetext{
Não são os resultados que interessam, mas a análise e a apreciação das áreas fortes e fracas do desempenho cognitivo do observado. O que interessa é compreender a dinâmica do perfil das suas funções cognitivas. Na APPD os aspectos qualitativos são igualmente apreciados ao lado dos quantitativos, estando em questão a ZDP e o PA (Potencial de Aprendizagem) do sujeito [...] O observador preocupa-se por meio da experiência de aprendizagem mediatizada
}

${ }^{9}$ VYGOTSKY, L. (1962). Thought and language. Cambridge, Ed. MIT. . (1986. Collected works: problems of general psychology. Nova Youk, Ed. Plenum. 
em detectar as micromudanças que o observado vai demonstrando ao longo da interação facilitadora, intencional, transcendente e significativa, tentando interpretar os efeitos proativos e prospectivos da mediatização co-construída entre os atores da observação. (FONSECA, 2002, p. 41 - 42)

Assim, o processo de avaliação deste projeto teve como estratégia de mediatização a leitura, a orientação, a pergunta, o diálogo, a partilha e o encorajamento dos estudantes em procurar e descobrir respostas, desenvolvendo consequentemente competências transversais de gestão de projetos, trabalho em equipe, desenvolvimento pessoal e comunicação, dotando de estruturas de aprendizagem mais ativas e eficientes, com possível aplicação em uma ampla gama de domínios, principalmente na área da Educação Matemática, em que as estratégias são contextualizadas e totalmente interdependentes. (D’AMBROSIO, 2009, p. 8)

Esclarecemos que a metodologia de trabalho com Grupos Interativos não tem um modelo fechado, pois as fases de transformação de cada comunidade de aprendizagem têm um contexto próprio, ou seja, em cada escola este processo pode ocorrer de formas diferentes (em relação às formas de fazê-lo como ao tempo de realização). Por esta razão, nesta pesquisa houve uma base comum que foi pautada no diálogo e nos acordos feitos com a comunidade educativa participante.

No que tange à proposta das partilhas de experiências matemáticas interdisciplinares realizadas pelos (as) educadores (as) da EI e do EFI, é importante destacar que o planejamento, as orientações e o acompanhamento constante da pesquisadora/Coordenadora Pedagógica permitiram a sequência linear do trabalho de tal forma que a sistematização das atividades aplicadas em sala de aula ocorresse de maneira clara e objetiva.

Conduzir pesquisas inovadoras e desenvolver metodologias ativas e interdisciplinares é um grande desafio que deve ser abraçado por todos os agentes educativos de uma escola. Às vezes é preciso adequar os métodos às circunstâncias e tomar decisões conscientes para abrigar uma diversidade de conceitos, havendo uma visão clara das diferenças, das igualdades, das dificuldades e dos avanços de cada um. Foi muito enriquecedor conhecer e divulgar as ideias e os projetos, observar e orientar as estratégias para tornar o ensino da Matemática mais criativo e ver que podemos articular e fortalecer o elo desta disciplina com as outras; assim como fez o educador e escritor dos números e das letras Malba Tahan, que como considera D'ambrosio (2009, p. 13), foi capaz de fazer da matemática um veículo de ensinamentos superiores de moral, de amor e de respeito pelo diferente. 


\section{REFERÊNCIAS}

AMARO, Ana; PÓVOA, Andreia; MACEDO. L. Metodologia da investigação: a arte de fazer questionários. Porto: Faculdade de Ciências da Universidade do Porto Departamento de Química, 2004/2005.

ARAÚJO. Ulisses Ferreira de. Pedagogia de Projetos. Considerações sobre a Vídeo-aula 17 do Curso de Especialização em Ética, Valores e Cidadania na Escola. USP/UNIVESP. 2011. Disponível em: https://meilycass.wordpress.com/2011/10/08/video-aula-17pedagogia-de-projetos/ Acesso em 11 de julho de 2015.

ASSMANN, Hugo. Reencantar a educação - rumo à sociedade aprendente. Petrópolis, RJ: Editora Vozes, 2000.

BRASIL. Secretaria de Educação Fundamental. Parâmetros Curriculares Nacionais: Matemática. Brasília: MEC, 1997.

INEP (Instituto Nacional de Estudo e Pesquisas Educacionais Anísio Teixeira).

Índice de Desenvolvimento da Educação Básica (IDEB) - Resultados e Metas. Brasília: MEC/Inep, 2011 e 2012.

- INEP (Instituto Nacional de Estudo e Pesquisas Educacionais Anísio Teixeira).

Sistema de Avaliação ANEC. Relatório da Escola $5^{\circ}$ Ano do Ensino Fundamental I. Instituto Nossa Senhora do Carmo. Guaratinguetá-SP, 2013.

Brazil's other passion: Malba Tahan and The man who counted. Disponível em: < http://www.bbc.com/news/magazine-27254747> Acesso em 26 de agosto de 2014.

CARVAlho, B. C. FERnANDES, E. A história do Tangram. Disponível em: <https://www.youtube.com/watch?v=R0kLmupaoOk> Acesso em 06 de janeiro de 2015.

CRISTOV, Luiza Helena da Silva. Educação continuada: função essencial do Coordenador Pedagógico. São Paulo: Edições Loyola, 1998. 
D’AMBROSIO. U. Educação Matemática: da teoria à prática. Campinas, SP: Papirus, 2009.

DINIZ, M. I. Os problemas convencionais nos livros didáticos. In: Ler, escrever e resolver problemas: habilidades básicas para aprender matemática. Porto Alegre: Artmed, 2001.

DOMINGUES, Isaneide. O coordenador pedagógico e a formação contínua do docente na escola. São Paulo: Cortez, 2014.

FARIA, Juraci Conceição de. A literatura infantil de Malba Tahan: um caleidoscópio interdisciplinar. Disponível em: http://www.jornalolince.com.br/2013/abr/educacao/5021-a-literatura-infantil-de-malba-

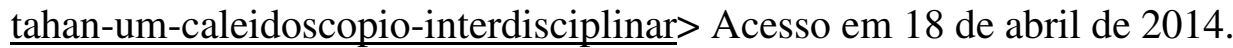

FARIA, Juraci Conceição de. A prática educativa de Júlio César de Mello e Souza Malba Tahan: um olhar a partir da concepção de Interdisciplinaridade de Ivani Fazenda. 2004. 275 p. Dissertação (Mestrado em Educação) - Universidade Metodista de São Paulo, São Bernardo do Campo. Disponível em: < http://www.malbatahan.com.br/artigos/dissertacao_juracycfaria.pdf $>$ Acesso em 10 de abril de 2014.

FARIA, Juraci Conceição de. O sucesso editorial de Malba Tahan: história, comunicação e marketing da obra "O homem que calculava". In: XXVII Simpósio de História do Vale do Paraíba, 2014. Aparecida: Editora O Lince, 2014.

FAZENDA, I. C. A. (Org.); GODOY, H. P. Interdisciplinaridade: pensar, pesquisar e intervir. São Paulo: Cortez, 2014.

FAZENDA, I. C. A. (Org.) Dicionário em construção: interdisciplinaridade. São Paulo: Cortez, 2001. 
Práticas interdisciplinares na Escola. São Paulo: Cortez, 1993.

FERREIRA, Aurélio Buarque de Holanda. Minidicionário da Língua Portuguesa. $4^{\mathrm{a}}$ Ed. Rio de Janeiro: Editora Nova Fronteira, 2001.

FREIRE, Paulo. Pedagogia do oprimido. $17^{\mathrm{a}}$ ed. Rio de Janeiro: Editora Paz e Terra. 1987.

Pedagogia da autonomia: saberes necessários à prática educativa. 36 ed. Rio de Janeiro: Editora Paz e Terra S/A, 1996 e 2000.

FONSECA, Vitor. Interatividade na aprendizagem: avaliação psicopedagógica dinâmica. São Paulo: Editora Salesiana, 2002.

GADOTTI, M. Educação e poder - introdução à pedagogia do conflito. $11^{\mathrm{a}}$ ed. São Paulo: Cortez, 1998.

GARCÍA, C. Y. Comunidades de Aprendizaje: de la segregación a la inclusión. 2004. Tese (Doutorado) - Departament de teoria sociológica, filosofia del dret e metodologia de les ciències socials, Universitat de Barcelona, Barcelona, 2004.

GARRUTTI, Érica Aparecida; SANTOS, Simone Regina dos. A interdisciplinaridade como forma de superar a fragmentação do conhecimento. Revista de Iniciação Científica da FFC, v. 4, n. 2, 2004. p. 187-197. Disponível em: < http://www2.marilia.unesp.br/revistas/index.php/ric/article/viewFile/92/93> Acesso em 12 de abril de 2014.

INSTITUTO NACIONAL DE ESTUDOS E PESQUISAS EDUCACIONAIS ANÍSIO TEIXEIRA (INEP). Matrizes de Matemática do $5^{\circ}$ ano do Ensino Fundamental. Disponível em: < http://portal.inep.gov.br/web/saeb/32> Acesso em 20 de janeiro de 2015. 
LIBÂNEO, José Carlos; OLIVEIRA, João Ferreira de; TOSCHI, Mirza SEABRA. Educação escolar: políticas, estrutura e organização. São Paulo: Cortez, 2003.

LIBÂNEO, José Carlos. Que destino os educadores darão à pedagogia. In PIMENTA, S. G. (Org.). Pedagogia: ciência da educação? São Pauo: Cortez, 1996, p. 107-134.

Organização e gestão da escola: teoria e prática. Goiânia: Editora Alternativa, 2001.

MACHADO, N. J. Matemática e língua materna: análise de uma impregnação mútua. São Paulo: Cortez, 1990, p.58.

Os caminhos da interdisciplinaridade. Consideração sobre a Vídeoaula 2 do Curso de Especialização em Ética, Valores e Cidadania na Escola. USP/UNIVESP. 2011. Disponível em: https://meilycass.wordpress.com/2011/09/10/videoaula-2-os-caminhos-da-interdisciplinaridade/ Acesso em 10 de julho de 2015.

MARIGO, A.F.C.; BRAGA, F. M.; CONSTANTINO, F. L.; MOREIRA, R.; MELLO, R.R.; GIROTTO, V.C.; GABASSA, V. Comunidades de aprendizagem: compartilhando experiências em algumas escolas brasileiras. Políticas Educativas, Porto Alegre, v. 3, n. 2, p. 74 a 89, 2010 - ISSN: 1982-3207. Universidade Federal de São Carlos e Universidade Federal de Goiás. Disponível em: < http://seer.ufrgs.br/Poled/article/viewFile/22723/13208> Acesso em 13 de abril de 2014.

MARQUES, Ramiro. O livro das virtudes de sempre. São Paulo: Ed. Landy, 2001.

MORIN, Edgar. A cabeça bem-feita: repensar a reforma, reformar o pensamento. Tradução Eloá Jacobina. 8ª ed. Rio de Janeiro - RJ: Bertrand Brasil, 2003.

MOSÉ, Viviane. Os desafios contemporâneos: a educação. (Café Filosófico) Disponível em <https://www.youtube.com/watch?v=hRfZLQrAt5A> Acesso em 19 de julho de 2015.

Educação na era planetária. Palestra realizada para o Segundo ciclo do Fórum Universo do Conhecimento "Planeta Terra: um olhar transdisciplinar". UNESCO, 
Paris, 2005. Disponível em: https://www.youtube.com/watch?t=291\&v=JLV-oxL6mAw Acesso em 11 de julho de 2015.

MOYSÉS, Lucia. Aplicações de Vygotsky à Educação Matemática. $11^{\mathrm{a}}$ ed. Campinas, SP: Papirus, 2012.

NÓVOA, António. Formação de professores e profissão docente. In: Os professores e a sua formação. Lisboa: Dom Quixote, 1995.

OLIVEIRA, Cristiane Coppe de Oliveira. A sombra do arco-íris: um estudo histórico/mitocrítico do discurso pedagógico de Malba Tahan. 2007. 171 p. Tese (Doutorado em Educação na área de Ensino de Ciências e Matemática) - Universidade de São Paulo, São Paulo, 2007.

PRATA, Alvaro. Interdisciplinaridade exige competências sólidas. Palestra ministrada no $3^{\circ}$ Encontro Acadêmico Internacional - Interdisciplinaridade nas Universidades Brasileiras - Resultados e Desafios. Brasília, maio, 2014. Disponível em: http://www.brasil.gov.br/ciencia-e-tecnologia/2014/05/interdisciplinaridade-exige competencias-solidas-diz-pesquisador Acesso em 19 de julho de 2015.

PERRENOUD, P.; THURLER, M. G.; MACEDO, L. de; MACHADO, N. J.; ALLESSANDRINI, C. D. As competências para ensinar no século XXI: a formação dos professores e o desafio da avaliação. Porto Alegre: Artmed, 2002.

PERRENOUD, Philipe. Construir as competências desde a escola. Porto Alegre. Artmed Sul, 1998.

Dez novas competências para ensinar. Porto Alegre. Artmed, 2000.

REZENDE PINTO, J. M. de. A teoria da ação comunicativa de Jürgen Habermas: conceitos básicos e possibilidades de aplicação à administração escolar. Paideia (Ribeirão Preto), $\quad \mathrm{n}^{\circ} \quad 8-9 \quad$ Feb./Aug. $1995 . \quad$ Disponível em: 
http://www.scielo.br/scielo.php?script=sci_arttext\&pid=S0103-863X1995000100007 Acesso em 19 de julho de 2015.

RIOS, Terezinha Azerêdo. Ética e competência. 6 ed. SP: Cortez, Volume 16, 1997.

RIOS, Terezinha Azerêdo. Compreender e ensinar - por uma docência de melhor qualidade. 2 ed. SP: Cortez, 2001.

RODRIGUES, Eglen Silvia Pípi. Grupos Interativos: uma proposta educativa. 2010. 246 p. Tese (Doutorado em Educação na área de Metodologia de Ensino) - Universidade Federal de São Carlos, São Carlos, 2014. Acesso em 12 de abril de 2014.

Disponível em: $<$ http://www.bdtd.ufscar.br/htdocs/tedeSimplificado/tde_busca/arquivo.php?codArquivo=3 $377>$

SADOVSKY, Patricia. Falta fundamentação didática no ensino da Matemática. 2007. Ed. $199 . \quad$ Disponível em: $<$ http://revistaescola.abril.com.br/matematica/fundamentos/fundamentacao-didaticaensino-matematica-428262.shtml> Acesso em 25 de set. de 2015.

SCOPEL, Alexandro José Correia. Contribuições didáticas de Malba Tahan para o ensino de matemática. 2010. 118 p. Dissertação (Mestrado em Ensino de Ciências e Matemática) - Pontifícia Universidade Católica de Minas Gerais. Disponível em: < http://www.biblioteca.pucminas.br/teses/EnCiMat_ScopelAJC_1.pdf> Acesso em 12 de abril de 2014.

SMOLE, K. S. Alfabetização Matemática e os Processos Mentais Básicos. Encontro de formação docente para os educadores da Educação Infantil da Rede Salesiana de Escolas (Vale do Paraíba). Dia 26/03/2015, em São José dos Campos-SP.

SMOLE, K. S; DINIZ, M. I. Ler, escrever e resolver problemas: habilidades básicas para aprender matemática. Porto Alegre: Artmed, 2001. 
SMOLE, K. C. S. et al. Era uma vez na Matemática: uma conexão com a literatura infantil. Instituto de Matemática e Estatística (IME), Centro de Aperfeiçoamento de Ensino de Matemática (CAEM). 6 ed. São Paulo, 2007.

SMOLE, K. S.; DINIZ, M. I.; MILANI, E. Jogos de matemática: [recurso eletrônico]. $6^{\circ}$ ao $9^{\circ}$ ano. Porto Alegre: Artmed, 2007. (Série Cadernos do Mathema - Ensino Fundamental)

SOLÉ, I. Estratégias de leitura. 6.ed. Porto Alegre: Artmed, 1998.

TAHAN, Malba. A arte de ler e contar histórias. Rio de Janeiro: Editora Conquista, 1966.

A arte de ser um perfeito mau professor. Rio de Janeiro: Casa Editora Vecchi LTDA., 1967.

Antologia da matemática. São Paulo: Editora Saraiva, 1961. 2 v.

. Didática da matemática. São Paulo: Editora Saraiva, 1961. 2 v.

. Matemática divertida e delirante. São Paulo: Editora Saraiva, 1962. 2 v.

Meu anel de sete pedras. 2a ed. Rio de Janeiro: Record, 1998.

O homem que calculava. Rio de Janeiro; Editora Record, 1949.

O mundo precisa de ti, professor. Rio de Janeiro: Vecchi, 1967.

. Páginas do bom professor. Rio de Janeiro: Vecchi, 1969.

Roteiro do bom professor. Rio de Janeiro: Vecchi, 1969.

. Os números governam o mundo. Rio de Janeiro: Ediouro, 1998. 
THURLER, M. G. O desenvolvimento profissional dos professores: novos paradigmas, novas práticas. In: As competências para ensinar no século XXI. Porto Alegre: Artmed, 2002.

VIEIRA, C. T.; VIEIRA, R. M. Literacia e pensamento crítico: um referencial para a educação em ciências e em matemática. Revista Brasileira de Educação. v. 18. n. 52. Jan-Mar. 2013.

VYGOTSKY, Lev. A formação social da mente. São Paulo: Editora Martins Fontes, 1984.

El desarrollo de los procesos psicológicos superiores. Barcelona:

Crítica, 2008. 
APÊNDICES 


\section{APÊNDICE A}

\section{Questionário: Perfil da Equipe Docente da EI e do EFI do ano letivo de}

Assinale as alternativas que condizem com o trabalho realizado para desenvolver as habilidades e competências matemáticas dos seus alunos:

\section{Para a abordagem dos conteúdos matemáticos:}

( ) Propor exemplos de situações relacionadas ao cotidiano;

( ) Propor exemplos de situações para fixar procedimentos;

( ) Decorar regras e fórmulas, aplicando-as a situações-problema;

( ) Propor problemas que envolvem aplicação de fórmulas e algoritmos;

( ) Partilhar entre os alunos as diferentes soluções, discutindo com a professora os processos utilizados;

( ) Trabalhar com os temas que aparecem em jornais/revistas, discutindo suas relações com a matemática;

( ) Propor jogos, pesquisas e dramatizações de histórias.

Outros:

2. Para a organização da sala de aula:

( ) Atividades em equipe;

( ) Atividades individuais;

( ) Interação entre os alunos e entre estes e o professor;

( ) Grupos interativos.

Outros:

3. Para os procedimentos de avaliação:

( ) Tarefas para casa;

( ) Trabalhos em grupo/equipe;

( ) Uso de provas/avaliações;

( ) Participação dos alunos durante as aulas;

( ) Elaboração de portfólios/relatórios;

( ) Desempenho dos alunos em atividades práticas;

( ) Autoavaliação.

Outros:

4. Experiência profissional (Individual):

Anos como professor/estagiário (a):

Número de escolas em que trabalha:

Tipo de escola em que leciona: ( ) pública ( ) particular

\section{Formação (Individual):}

Graduação em:

Pós-graduação em:

Participação em cursos/palestras no último ano: ( ) Sim ( ) Não

Lê regularmente revistas de divulgação científica? ( ) Sim ( ) Não

Tem conhecimentos dos Parâmetros Curriculares Nacionais de Matemática? ( ) Sim ( ) Não 


\section{APÊNDICE B}

\section{Autódromo: Biografia de Malba Tahan}

\section{Questão 1 - V V}

- Malba Tahan escrevia histórias árabes, mas era brasileiro.

- Malba Tahan era professor de matemática e os alunos gostavam de suas aulas. Ele era famoso, mas também brincalhão. Gostava de sapos desengonçados e mas adorava geometria.

\section{Questão 2 - F V}

- Malba Tahan escreveu 66 livros. (Malba Tahan escreveu 56 livros).

- O nome Malba Tahan significa "o moleiro do oásis de Malba".

Questão 3 - V F

- O nome verdadeiro de Malba Tahan era Júlio César de Mello e Souza.

- Malba Tahan nasceu em São Paulo e inventou este nome para pensarem que ele era um escritor árabe. (Nasceu no Rio de Janeiro)

\section{Questão 4 - F F}

- O livro mais famoso de Malba Tahan é "O Homem que fazia Contas", que conta a aventura de Beremís, um árabe que gostava de resolver problemas da vida com soluções malucas e cheias de matemática. ("O Homem que Calculava”)

- Malba Tahan era um ótimo aluno de Matemática quando era criança. (Malba Tahan tinha dificuldade para aprender Matemática)

\section{Questão 5 - V V}

- Quando era criança, a brincadeira preferida de Malba Tahan era brincar com sapos e escrever pequenas revistas.

- O nome da revista que Malba Tahan escrevia quando tinha 10 anos era "ERRE". Ela tinha histórias, notícias e jogos. 


\section{Questão 6 - V F}

- Nas férias, Malba Tahan ia para Queluz, que fica no Estado de São Paulo, na beira do Rio Paraíba.

- Quando ficou adulto, Malba Tahan continuou colecionando sapos de verdade. (Sapos de louça)

\section{Questão 7 - V V}

- Quando entrava em sala de aula, o Professor Júlio César de Mello e Souza dizia aos seus alunos: "Salam Aleikum", que significa "A paz esteja contigo".

- O Professor Mello e Souza escrevia na lousa muitas adivinhas matemáticas para seus alunos resolverem. A aula dele era nota 10 !

\section{Questão 8 - V V}

- Malba Tahan ficou conhecido como "o carioca das arábias" e como "o Pelé dos números".

- O Dia Nacional da Matemática foi dedicado ao dia do aniversário de Júlio César de Mello e Souza, 06 de maio.

\section{Questão 9 - F F}

- Em 2015, comemoramos 200 anos do nascimento de Malba Tahan. (120 anos)

- O livro preferido de Malba Tahan na infância era "As Mil Noites". (As Mil e Uma Noites)

\section{Questão 10 - F V}

- Malba Tahan aprendeu a gostar de Matemática sozinho, sem a ajuda de ninguém. (O gosto pela Matemática veio das aulas do Professor Henrique César de Oliveira Costa).

Malba Tahan faleceu no dia 18 de junho de 1974, aos 79 anos de idade, de edema pulmonar agudo e trombose coronária. Foi sepultado no Rio de Janeiro. 


\section{APÊNDICE C}

Tabela de Controle do jogo "Autódromo: 5" Ano A"

AUTÓDROMO - BIOGRAFIA DE MALBA TAHAN - DIA 13/03/2015

TURMA: $5^{\circ}$ ANO A

\begin{tabular}{|c|c|c|c|c|c|}
\hline QUESTŐES & $\begin{array}{c}\text { GRUPO } \\
\text { "OS MATEMÁTICOS } \\
\text { 1" }\end{array}$ & $\begin{array}{c}\text { GRUPO } \\
\text { “OS MATEMÁTICOS } \\
2 \text { 2” }\end{array}$ & $\begin{array}{c}\text { GRUPO } \\
\text { "OS MATEMÁTICOS } \\
3 "\end{array}$ & $\begin{array}{c}\text { GRUPO } \\
\text { "OS } \\
\text { MULTIPLICADORES" }\end{array}$ & $\begin{array}{c}\text { GRUPO } \\
\text { "OS DIVISORES" }\end{array}$ \\
\hline 1 & $F V$ & $\begin{array}{lll}V V & 1\end{array}$ & VV 1 & $F V$ & $F V$ \\
\hline 2 & $V F$ & $F V$ & $V F$ & FF & $V F$ \\
\hline 3 & VV & VF & $F V$ & $V F$ & $V F$ \\
\hline 4 & FF & $F F$ & $\frac{1}{F F}$ & $F F$ & $F F$ \\
\hline 5 & VV & $V V$ & $F V$ & VV & $V V$ \\
\hline 6 & VV & $\checkmark V$ & $\mathrm{FV}$ & $V F$ & $V F$ \\
\hline 7 & VV & VV & $\checkmark V$ & VV & $V V$ \\
\hline 8 & $F V$ & $V F$ & $F V$ & $V F$ & $F V$ \\
\hline 9 & $F V$ & $F V$ & $F F$ & $F V$ & $F F$ \\
\hline 10 & VF & $\mathrm{FV}$ & $\sqrt{F}$ & $\mathrm{FV}$ & $\mathrm{FV}$ \\
\hline $\begin{array}{l}\text { TOTAL DE } \\
\text { ACERTOS }\end{array}$ & 03 & 07 & 04 & 06 & 07 \\
\hline
\end{tabular}

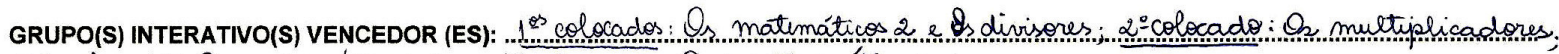






\section{APÊNDICE D}

Tabela de Controle do jogo "Autódromo: 5” Ano B"

AUTÓDROMO - BIOGRAFIA DE MALBA TAHAN - DIA 13/03/2015

TURMA: $5^{\circ}$ ANO B

\begin{tabular}{|c|c|c|c|c|c|c|}
\hline QUESTÓES & $\begin{array}{l}\text { GRL } \\
\text { "OS SÁ } \\
\text { MATEM }\end{array}$ & $\begin{array}{l}\text { SDA } \\
\text { CA" }\end{array}$ & $\begin{array}{l}\text { GRUPO } \\
\text { "DIVISÃO" }\end{array}$ & $\begin{array}{l}\text { GRUPO } \\
\text { "ADIÇÃO" }\end{array}$ & $\begin{array}{c}\text { GRUPO } \\
\text { "SUBTRAÇÃO" }\end{array}$ & $\begin{array}{c}\text { GRUPO } \\
\text { "AS FÓRMULAS" }\end{array}$ \\
\hline 1 & VV & 1 & VF & VV & VV & VV \\
\hline 2 & $F V$ & 1 & VV & $\sqrt{V}$ & VF & VF \\
\hline 3 & VU & & VF & $V F$ & VV & VV \\
\hline 4 & $V F$ & & $F F$ & $F F \quad 1$ & $F V$ & VF \\
\hline 5 & VV & 1 & $E V$ & $V V \quad 1$ & $F V$ & VV 1 \\
\hline 6 & VF & 1 & $E V$ & $V F 1$ & $V F 1$ & $\checkmark F 1$ \\
\hline 7 & VV & 1 & VV 1 & VV 1 & VV 1 & $V \vee 1$ \\
\hline 8 & $F V$ & & $F V$ & $F V$ & $V v$ & $F V$ \\
\hline 9 & $F F$ & 1 & $E V$ & $F V$ & $F V$ & $F E$ \\
\hline 10 & $F F$ & & VV & $F F$ & $F F$ & $F F$ \\
\hline $\begin{array}{l}\text { TOTAL DE } \\
\text { ACERTOS }\end{array}$ & 06 & & 03 & 06 & 04 & 05 \\
\hline
\end{tabular}

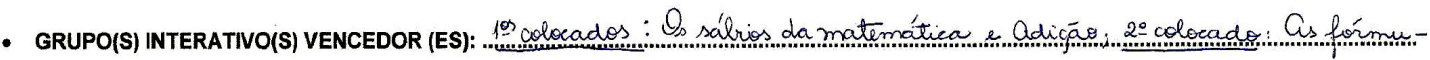

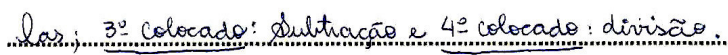




\section{APÊNDICE E}

Convites para a Exposição Malbatahânica e Reunião de Pais

CONVITE: "REUNIÃO DE PAIS/RESPONSÁVEIS E EXPOSIÇÃO MALBATAHÂNICA"

Prezados Senhores Pais e Responsáveis,

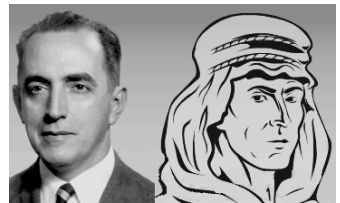

Convidamos para a "Reunião de Pais e Responsáveis" do Ensino Fundamenta l, com o objetivo de partilhar o trabalho pedagógico desenvolvido, referente ao $\mathbf{1}^{\circ}$ Trimestre.

A Reunião será conduzida pelas próprias Professoras, que abordarão os avanços das turmas e farão orientações importantes para o $2^{\boldsymbol{o}}$ Trimestre.

\begin{tabular}{|c|c|c|c|}
\hline \multicolumn{4}{|c|}{ ENSINO FUNDAMENTAL I } \\
\hline ANOS & DIAS / HORÁRIOS & $\begin{array}{c}\underline{1}^{\circ} \text { MOMENTO } \\
\text { Partilha e Vivência } \\
\text { de Experiências } \\
\text { Matemáticas }\end{array}$ & $\begin{array}{c}\frac{2^{\circ} \text { MOMENTO }}{\text { - Orientações para o } 2^{o} \text { Trimestre }} \\
\text { - Exposição de trabalhos dos estudantes }\end{array}$ \\
\hline $1^{\text {os }}$ & \multirow{2}{*}{$\begin{array}{c}27 / 05 / 2015\left(4^{a} \text { feira }\right) \\
18: 15 \text { às } 19: 30\end{array}$} & Sala 14 & \multirow{5}{*}{$\begin{array}{c}\text { Sala de aula da turma, } \\
\text { com a Professora. }\end{array}$} \\
\hline $2^{\text {os }}$ & & Sala 16 & \\
\hline $3^{o_{S}}$ & \multirow[t]{3}{*}{$28 / 05 / 2015\left(5^{a}\right.$ feira $)$} & Sala 14 & \\
\hline $4^{o s}$ & & Sala 15 & \\
\hline $5^{o_{5}}$ & & Sala 16 & \\
\hline
\end{tabular}

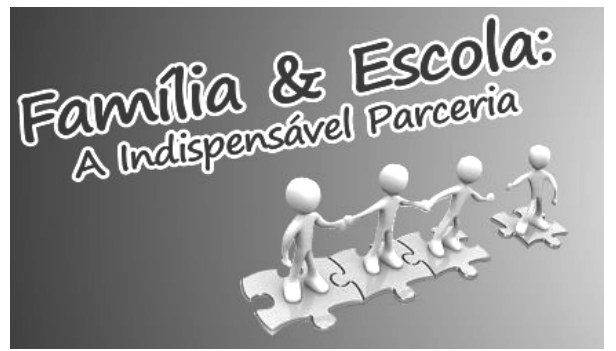

Contamos com a presença de todos e por isso gostaríamos de obter uma confirmação, por meio do canhoto em anexo.

Atenciosamente,

Direção, Orientação Pedagógica e Professoras.

$8<$

( ) Sim, confirmo a minha presença.

( ) Não confirmo a minha presença, porque

Estudante: Ano .........

Professora:

Data:

$. / 05 / 2015$.

Assinatura do Responsável: 

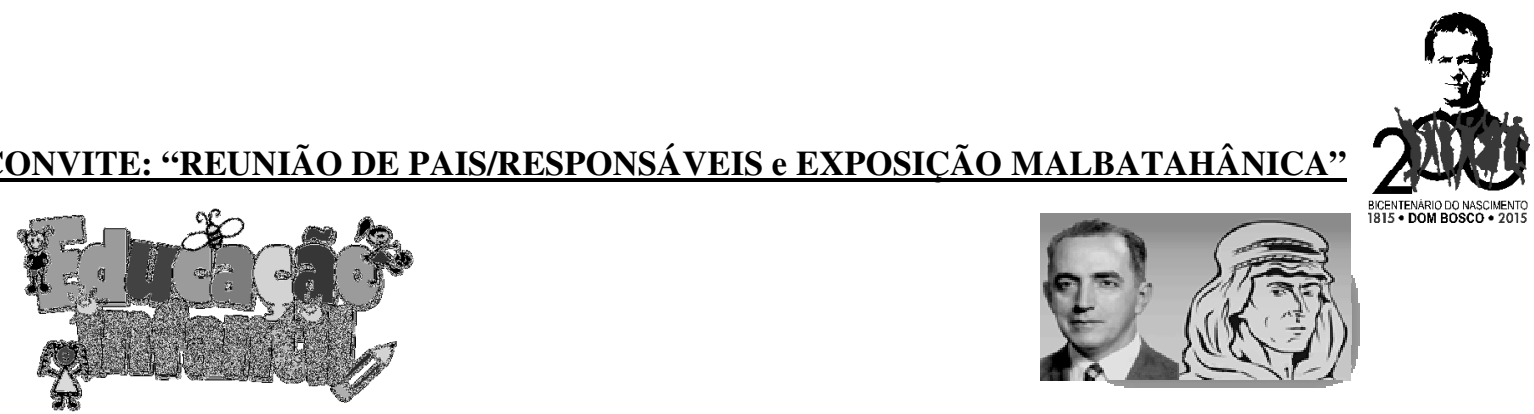

Prezados Senhores Pais e Responsáveis,

Todas as ações desenvolvidas neste $1^{\circ}$ Semestre foram pensadas com muito carinho para desenvolver a aprendizagem dos pequenos estudantes. Por isso, esperamos por vocês na $\underline{\text { Reuniãa } \mathbf{d e}}$ Pais/Responsáveis da Educação Infantil, momento de grande importância.

A Reunião será conduzida pelas próprias Professoras, que abordarão os avanços das turmas e farão orientações importantes para o $2^{\circ}$ Semestre.

\begin{tabular}{|c|c|c|c|}
\hline \multicolumn{4}{|c|}{ EDUCAÇÃO INFANTIL } \\
\hline TURMAS & DIAS / HORÁRIOS & $\begin{array}{c}1^{\circ} \text { MOMENTO } \\
\text { Partilha e Vivência } \\
\text { de Experiências } \\
\text { Matemáticas }\end{array}$ & $\begin{array}{c}\frac{2^{o} M O M E N T O}{2} \\
\text { - Orientações para o } 2^{o} \\
\text { Semestre } \\
\text { - Exposição de trabalhos dos } \\
\text { estudantes }\end{array}$ \\
\hline $\begin{array}{c}\text { Infantil I A } e \\
B\end{array}$ & $\begin{array}{c}08 / 06 / 2015\left(2^{a} \text { feira }\right) \\
18: 30 \text { às } 19: 30\end{array}$ & Sala 14 & Sala de aula da turma, \\
\hline $\begin{array}{c}\text { Infantil I Ce } \\
\qquad D\end{array}$ & & Sala 15 & com a Professora. \\
\hline $\begin{array}{c}\text { Infantil II A } e \\
\text { B }\end{array}$ & $\begin{array}{c}09 / 06 / 2015\left(3^{a} \text { feira }\right) \\
18: 30 \text { às 19:30 }\end{array}$ & Sala 14 & \\
\hline $\begin{array}{c}\text { Infantil III A } \\
\text { e B }\end{array}$ & & Sala 15 & \\
\hline
\end{tabular}

Contamos com a presença de todos e por isso gostaríamos de obter uma confirmação, por meio do canhoto em anexo.

Gratas pela parceria! Direção, Orientação Pedagógica e Professoras.

$8<$

( ) Sim, confirmo a minha presença.

( ) Não confirmo a minha presença, porque

Estudante: Infantil

Professora: Data: $. / 06 / 2015$.

Assinatura do Responsável: 
ANEXOS 


\section{ANEXO A \\ "Termo de Consentimento Livre e Esclarecido para a Direção do Instituto Nossa Senhora do Carmo"}

\section{"UMA PROPOSTA INTERDISCIPLINAR PARA GRUPOS INTERATIVOS UTILIZANDO A LITERATURA INFANTIL DE MALBA TAHAN"s}

Pesquisadora responsável: Meily Cassemiro Santos.

Eu, Irmã Teresa Cristina Pizani Domiciano, Diretora do Instituto Nossa Senhora do Carmo, declaro ter conhecimento sobre a pesquisa "UMA PROPOSTA INTERDISCIPLINAR PARA GRUPOS INTERATIVOS UTILIZANDO A LITERATURA INFANTIL DE MALBA TAHAN" que tem como objetivo geral aplicar as Recreações Matemáticas de Júlio César de Mello e Souza Malba Tahan e a interdisciplinaridade como uma proposta educativa para superar as dificuldades do ensino de Matemática na Educação Infantil e no Ensino Fundamental I, a partir de Grupos Interativos.

É de meu conhecimento que a participação dos estudantes nesta pesquisa não implica em nenhum benefício pessoal, não é obrigatória e não trará riscos previsíveis. Os estudantes serão acompanhados e assistidos pela pesquisadora responsável durante a aplicação dos instrumentos de pesquisa (jogos, histórias, dramatizações e exposição malbatahânica), podendo fazer perguntas sobre qualquer dúvida que apareça durante todo o estudo.

Não haverá nenhuma forma de reembolso de dinheiro, já que com a participação na pesquisa, não teremos gastos.

Diante disso, aceito que os estudantes participem voluntariamente desta pesquisa, sabendo que os dados coletados estarão sob o resguardo científico e o sigilo profissional, e contribuirão para o alcance dos objetivos deste trabalho e para posteriores publicações dos dados.

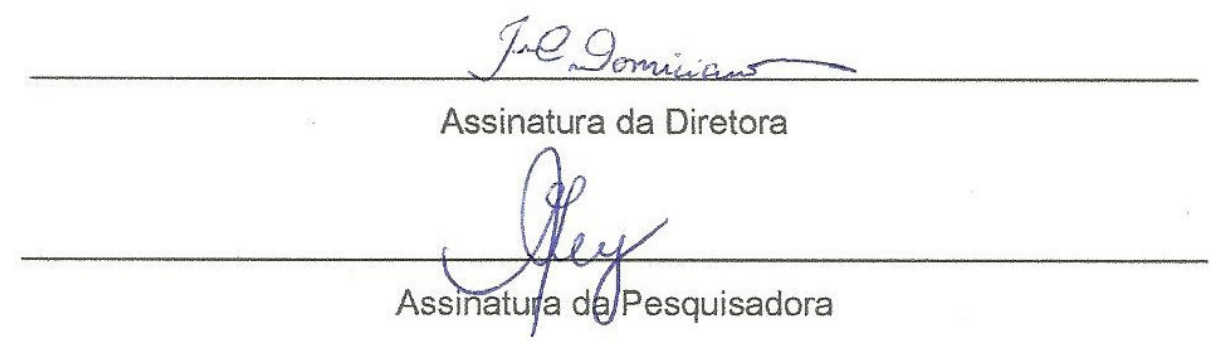

Guaratinguetá, 20101/2015 


\section{ANEXO B \\ "Modelo: Termo de Consentimento Livre e Esclarecido para Pais e/ou Responsáveis" “UMA PROPOSTA INTERDISCIPLINAR PARA GRUPOS INTERATIVOS UTILIZANDO A LITERATURA INFANTIL DE MALBA TAHAN"}

Pesquisador (a) responsável: Meily Cassemiro Santos.

$\mathrm{Eu}$ responsável do

(a) estudante residente no endereço

profissão declaro ter conhecimento sobre a pesquisa

“UMA PROPOSTA INTERDISCIPLINAR PARA GRUPOS INTERATIVOS UTILIZANDO A LITERATURA INFANTIL DE MALBA TAHAN" que tem como objetivo geral aplicar as Recreações Matemáticas de Júlio César de Mello e Souza Malba Tahan e a interdisciplinaridade como uma proposta educativa para superar as dificuldades do ensino de Matemática na Educação Infantil e no Ensino Fundamental I, a partir de Grupos Interativos.

É de meu conhecimento que a participação do meu (minha) filho (a) nesta pesquisa não implica em nenhum benefício pessoal, não é obrigatória e não trará riscos previsíveis. Caso queira, sei que há a possibilidade de desistência a qualquer momento, sem que isso cause prejuízo. Meu (minha) filho (a), portanto, será acompanhado e assistido pelo (a) pesquisador (a) responsável durante a aplicação dos instrumentos de pesquisa (jogos, histórias, dramatizações e exposição malbatahânica), podendo fazer perguntas sobre qualquer dúvida que apareça durante todo o estudo.

Não haverá nenhuma forma de reembolso de dinheiro, já que com a participação na pesquisa, não terei nenhum gasto.

Diante disso, aceito que meu (minha) filho (a) participe voluntariamente desta pesquisa, sabendo que os dados coletados estarão sob o resguardo científico e o sigilo profissional, e contribuirão para o alcance dos objetivos deste trabalho e para posteriores publicações dos dados.

Assinatura do Pai ou Responsável

Assinatura da Pesquisadora

Guaratinguetá, $/ 2015$ 


\section{ANEXO C \\ Avaliação Diagnóstica Inicial de Matemática}

Você está participando de uma Avaliação Diagnóstica, com o objetivo de avaliar suas habilidades e conhecimentos adquiridos até o momento. Faça com atenção e sem pressa, demonstrando tudo o que você sabe. Boa Prova!

Instruções:

1.A Prova só contempla questões de múltipla escolha.

2.Para cada uma das questões há quatro alternativas e somente uma deve ser assinalada. A marcação em mais de uma alternativa anula a questão.

1) (SAEB/PROVA BRASIL/2009) Em uma das aulas de matemática, aprendi sobre os poliedros e os corpos redondos. Em seguida, fui ao supermercado. Lá comprei uma caixa de sabão em pó, uma lata de óleo e uma bola. No caixa percebi que os três produtos tinham, respectivamente, a forma de:
(A) cubo, cone e circunferência.
(B) paralelepípedo, cone e esfera.
(C) cubo, cilindro e circunferência.
(D) paralelepípedo, cilindro e esfera
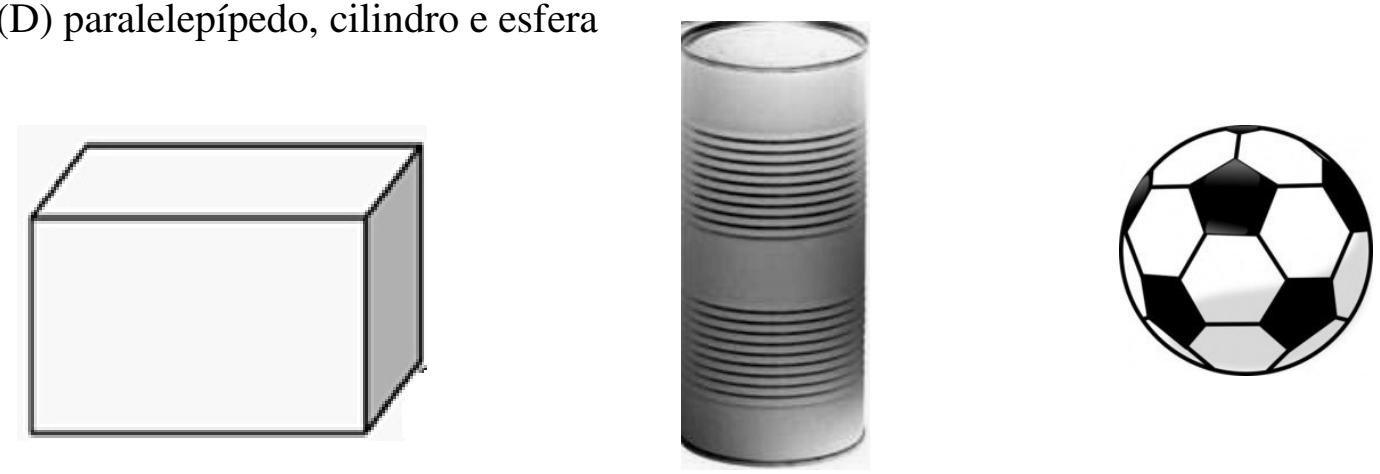

2) (SARESP/2007) A altura de Karen é 1,45 metros e a de seu irmão é 1,27 metros. Quantos centímetros Karen tem a mais que seu irmão?
(A) $28 \mathrm{~cm}$
(B) $18 \mathrm{~cm}$
(C) $15 \mathrm{~cm}$
(D) $12 \mathrm{~cm}$ 
3) (SARESP/2007) Compare os valores:
12,31
11,89
12,32
12,21

Escrevendo-os na ordem crescente, temos:
(A) 11,89
12,31
12,32
12,21
(B) 11,89
12,21
12,31
12,32
(C) 12,21
12,31
12,32
11,89
(D) 12,32
12,31
12,21
11,89

4) (SAEB/PROVA BRASIL/2009) Os desenhos a seguir representam o formato de um jardim que será construído em uma praça da cidade. Inicialmente pensou-se num jardim pequeno, mas devido ao grande entusiasmo que causou na população da cidade, o prefeito solicitou que fizessem um novo projeto, com desenho maior. O novo projeto terá área:
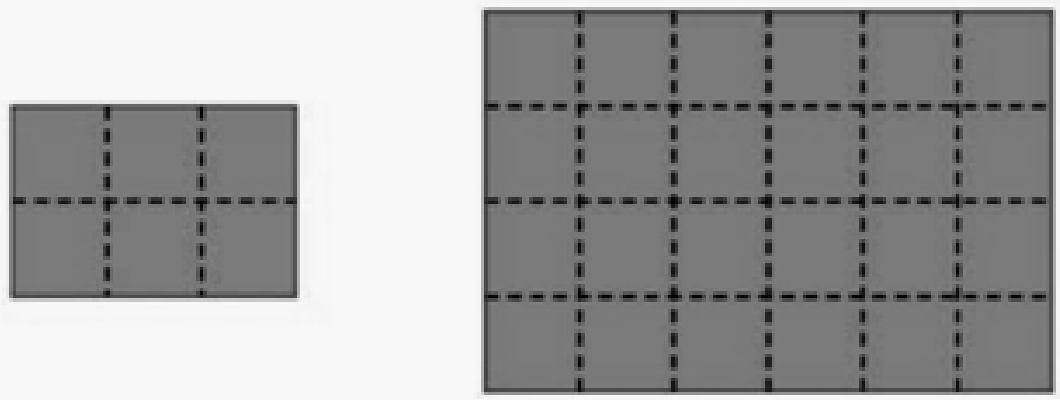
(A) 2 vezes maior que o primeiro.
(B) 3 vezes maior que o primeiro.
(C) 4 vezes maior que o primeiro.
(D) 6 vezes maior que o primeiro. 
5) (PROVA BRASIL/2011) O número de arestas do prisma pentagonal é:

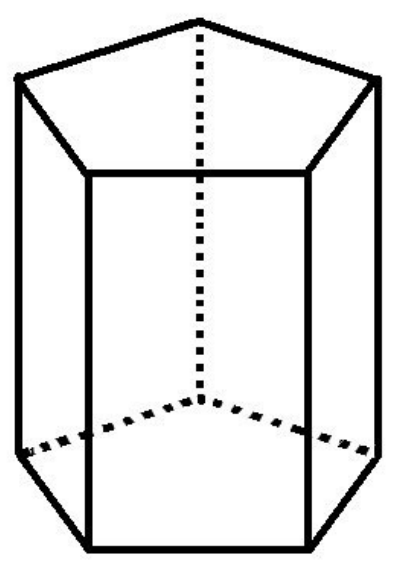
(A) 5 .
(B) 9 .
(C) 12 .
(D) 15 .

6) (SARESP/2012) Na Mercearia da Esquina, está afixada a tabela a seguir. Maria comprou 5 quilos de arroz, 2 de feijão e 5 de açúcar. Quanto gastou?

\begin{tabular}{|c|c|}
\hline \multicolumn{2}{|c|}{ OFERTA DA SEMANA } \\
\hline PRODUTO & PREÇO POR QUILO \\
\hline ARROZ & $\mathrm{R} \$ 1,20$ \\
\hline FEIJÃO & $\mathrm{R} \$ 2,00$ \\
\hline AÇÚCAR & $\mathrm{R} \$ 0,80$ \\
\hline
\end{tabular}
(A) $\mathrm{R} \$ 4,00$
(B) $\mathrm{R} \$ 10,00$
(C) $\mathrm{R} \$ 14,00$
(D) $\mathrm{R} \$ 20,00$ 
7) (SAEB/PROVA BRASIL/2009) Na escola em que Simone estuda foi apresentada uma peça teatral sobre a importância da reciclagem do lixo. O relógio a seguir mostra a hora de início e término da peça.

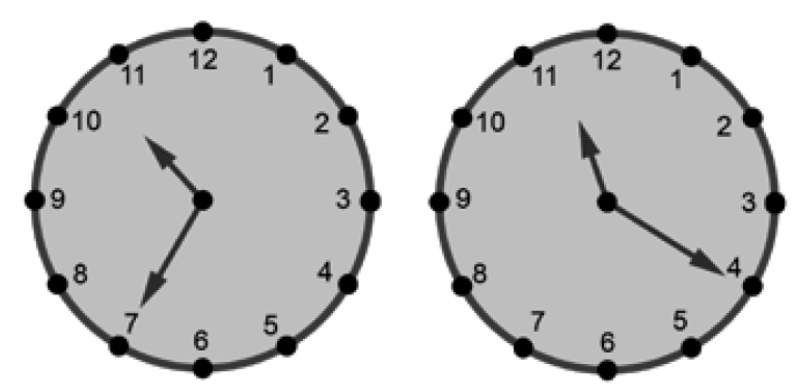

Quanto tempo de duração teve a apresentação?
(A) 1 hora.
(B) 20 minutos.
(C) 45 minutos.
(D) 55 minutos.

8) (SARESP/2012) Indique, dentre as opções abaixo, aquela que apresenta todas as afirmações corretas:
(A) 2, 3 e 6 são divisores de 12 .
(B) 12 é múltiplo de 2 , de 3 e de 9.
(C) 2, 3 e 7 são divisores de 7 .
(D) 12 é múltiplo de 24 e de 39.

9) (SARESP/2012) Luísa foi à sorveteria. Lá havia três sabores de sorvete: chocolate, morango e flocos; e dois tipos de cobertura: caramelo e chocolate.

O número de maneiras diferentes de Luísa escolher o seu sorvete com apenas um sabor e um tipo de cobertura é:
(A) 8
(B) 7
(C) 6
(D) 4 
10) (SAEB/PROVA BRASIL/2009) A biblioteca de uma escola tem 1 milhar de livros didáticos, 4 centenas de livros de literatura, 2 dezenas de livros de arte e 4 dicionários. Quantos livros há na biblioteca da escola?
(A) 1242 livros.
(B) 1244 livros.
(C) 1404 livros.
(D) 1424 livros. 


\section{ANEXO D}

\section{Artigo: "A Origem dos Números"}

A origem dos números representa na História da Matemática delicadíssimo problema que tem desafiado a paciência dos sábios e a tenacidade dos pesquisadores.

- Como surgiram os números?

Essa pergunta sob o véu de enganadora simplicidade leva-nos a perigoso labirinto de dúvidas e dificuldades inextricáveis.

Na falta de caminho seguro que nos conduza à solução do enigma, sigamos pela estrada ampla e ensolarada da Fantasia. Imaginemos como teriam ocorrido os episódios que mais de perto estariam relacionados com a origem dos números.

\section{NABOLED, O PASTOR}

Foi há trinta e três mil e duzentos e quarenta e quatro anos.

Estamos na pequena aldeia de Calneh, à margem direita do Eufrates, nas terras férteis e abençoadas da Babilônia.

Ali vivia o moço Naboled, o pastor, encarregado de zelar pela segurança de um dos belos rebanhos do Rei Chomabelus, apelidado "o sagaz".

Todos os dias, muito cedo ainda, ao romper da manhã, Naboled levantava-se do seu leito de couro de boi, retirava o rebanho do aprisco e levava-o para o campo. As ovelhas eram muitas; Naboled devia contá-las.

Contar, é, afinal, uma operação tão simples que pode ser feita por uma criança de quatro anos. Basta conhecer os números, um, dois, três, quatro...

Mas Naboled, o pastor de Calneh, naquele remotíssimo tempo, não conhecia os números. E mesmo assim, sem os números, o jovem babilônico contava as ovelhas do Rei Chomabelus.

E como podia o pastor contar o rebanho sem o auxílio dos números?

Recorria a um artifício muito simples que vamos explicar.

\section{AS PEDRINHAS ROLADAS}

À porta do aprisco erguia-se velha figueira. Nos dias quentes de verão, quando o sol, em seu carro de fogo, causticava a terra, os pastores do Rei abrigavam-se à sombra da árvore acolhedora e amiga. 
Eis o que fez Naboled. Amontoou sob a figueira uma coleção de pedrinhas roladas que ele pacientemente apanhara nas margens do Eufrates. Essas pedrinhas eram todas, mais ou menos, do mesmo tamanho, o comprimento de qualquer delas de pouco excedia a largura de dois dedos. Algumas eram claras como pérolas; outras pareciam levemente azuladas. Havia também muitas que tinham manchas escuras cor de tâmara e laivos avermelhados. Todos os pastores de Calneh admiravam a coleção das pedrinhas roladas de Naboled. Era agradável segurar uma porção delas na concha das mãos e depois deixá-las cair, uma a uma, levemente na areia.

Naboled zelava pelas suas pedrinhas arredondadas. Eram para ele de grande utilidade.

Vejamos porquê.

\section{AS OVELHAS E AS PEDRINHAS}

O rebanho devia deixar o aprisco pela manhã. Naboled via desfilar, diante dele, as ovelhas que partiam. Para cada ovelha que saía, Naboled separava uma pedrinha, e essas pedrinhas, assim separadas, formavam um montículo. O número total de ovelhas do rebanho era igual ao número de pedrinhas retiradas da coleção.

Ao cair da tarde, quando o rebanho voltava para o aprisco, Naboled procurava averiguar se o número de ovelhas correspondia ao número de pedrinhas do montículo. Para cada pedrinha (separada) devia corresponder uma ovelha. Verificada a correspondência, Naboled proclamava satisfeito:

- Não se extraviou nenhuma ovelha! Voltaram todas! Por Baal! Pela glória de Tanit!

E o bom zagal rendia graças aos deuses por ter, naquele dia, retornado do campo com seu rebanho intacto.

\section{O PASTOR INVENTA NOMES}

Com o passar dos dias, procurou Naboled simplificar o seu sistema de contar o rebanho. Resolveu atribuir a cada ovelha um nome, e esses nomes podiam ser contados pelos dedos de suas mãos: eka, dva, tri, catur, panca, sãs, sapta, nava e daca.

Se a última ovelha era daca ele já sabia que as ovelhas eram tantas quantos os dedos de suas mãos.

E, a seguir, viriam outras ovelhas: daca eka, daca dva, daca tri... e assim, até dva daca (vinte). As outras palavras seriam de acordo com o mesmo sistema: dva daca eka, dva daca dva, dva daca tri... e assim até tri daca (trinta). Para um rebanho numeroso o pastor teria que levar a sua contagem até panca daca nava (cinquenta e nove) e ovelha seguinte seria apontada pelo nome de gesh (sessenta): gesh eka, gesh dva, gesh tri...

E o pastor Naboled, com esse sistema, criou uma numeração falada. 
Com a palavra gesh (sessenta), por exemplo, designaria o pastor um certo grupo de carneiros, com essa mesma palavra designaria um grupo equivalente de camelos e de patos.

Essa palavra que não dependia da natureza da coleção exprimia, apenas, o resultado de uma operação - a contagem - "que se executa sem atender à natureza ou disposição dos objetos, desenvolvendo-se e terminando do mesmo modo em coleções semelhantes". Na contagem, cada objeto vale pela sua presença e não pelas qualidades que porventura tenha.

A operação pode demorar mais ou menos, terminar antes ou depois de vinte e, por pouco que a reflexão se exerça, apresenta-se ao entendimento como uma apreciação de quantidade. Contar as laranjas de um cesto é apreciar um dos modos por que a quantidade se realiza nessa coleção de objetos.

Ora, sendo tal apreciação independente da natureza e disposição dos objetos despojados estes pela imaginação das suas qualidades sensíveis, vem formar-se no entendimento o conceito de coleção de unidades, e nesta coleção, semelhante à que lhe deu origem, a quantidade só tem um modo, uma maneira de ser: é o número.

\section{$[\ldots]$}

TAHAN, Malba. Antologia da Matemática (2º Volume). Saraiva: São Paulo, 1961, p. 711. 


\section{ANEXO E \\ Artigo: "A origem da Geometria"}

O estudo da origem e evolução das diversas partes da Matemática apresenta dificuldades insuperáveis quando as nossas pesquisas atingem o largo período de alguns milênios, que corresponde propriamente à "pré-história" dessa ciência.

Os documentos que mais decididamente têm contribuído para a reconstituição aproximada da "pré-história" da Matemática, provêm de quatro grandes civilizações completamente diversas: caldaia-assíria, egípcia, chinesa e hindu.

Certos documentos concernentes à Matemática dos caldeus, datam de 3.000 anos antes de Cristo, ao passo que os documentos egípcios mais antigos precedem de 1.700 anos, mais ou menos, à era cristã.

Os fragmentos que vieram revelar à ciência o desenvolvimento da Matemática, na famosa Babilônia, são numerosíssimos, é verdade, mas completamente isolados uns dos outros.

Os caldeus adotavam - e a tal respeito não subsiste dúvida alguma - um sistema de numeração que tinha por base o número 60, isto é, no qual 60 unidades de uma ordem formam uma unidade de ordem imediatamente superior. E com tal sistema chegavam apenas ao número 12960000, que corresponde à quarta potência da base 60 .

A Geometria dos caldeus e assírios tinha um caráter essencialmente prático e era utilizada nos diversos trabalhos rudimentares de agrimensura. Sabiam decompor, para determinação da área, um terreno irregular em triângulos retângulos, retângulos e trapézios. As áreas do quadrado (como caso particular do retângulo), do triângulo retângulo e do trapézio são corretamente estabelecidas. Chegaram também (3.000 anos antes de Cristo!) ao cálculo do volume do cubo, do paralelepípedo e talvez do cilindro.

É interessante assinalar que na representação dos carros assírios as rodas apareciam com 6 raios, opostos diametralmente e formando ângulos centrais iguais. Isso nos leva a concluir, com segurança, que os caldeus conheciam o hexágono regular e sabiam dividir a circunferência em 6 partes iguais. Cada uma dessas partes da circunferência era dividida em 60 partes iguais (por causa do sistema de numeração) resultando daí a divisão total da circunferência em 360 partes ou graus. 


\section{O berço da Geometria}

Nos túmulos faraônicos, os árabes descobriram certos papiros - documentos antiquíssimos - de alto valor histórico e científico e com auxílio dos quais foi possível apreciar o desenvolvimento notável da Matemática entre os egípcios.

Os historiadores gregos, sem exceção, procuram colocar no Egito o berço da Geometria, e atribuir, portanto, aos habitantes do vale do Nilo a invenção dessas ciências. As periódicas inundações do célebre rio forçaram os egípcios ao estudo da Geometria, pois uma vez passado o período da grande cheia, quando as águas retomavam o seu nível normal, era necessário repartir novamente as terras, e entregar aos senhores as antigas propriedades, perfeitamente delimitadas. A pequena faixa de terra, rica e fértil, era disputada por muitos interessados; faziam-se medições rigorosas a fim de que cada um, sem prejuízo dos outros fosse reintegrado na posse exata de seus domínios.

Os "papiros" egípcios mais notáveis são: de Kahun, de Moscow (do qual reproduzimos um fragmento) e o papiro Rhind - sendo este último considerado como o monumento capital da Matemática egípcia.

TAHAN, Malba. Antologia da Matemática 1.p. 123 a 125, 1960.

\section{Artigo: "Um polígono na poesia"}

Entre as figuras poligonais o geômetra aponta-nos o pentágono.

É fácil defini-la:

- Pentágono é o polígono de cinco lados.

Os poetas, em lances prodigiosos de inspiração, conseguem levar esse polígono banalíssimo para os versos e encravá-lo entre as rimas e imagens mais ousadas.

$[\ldots]$

O saudoso poeta gaúcho Atila Guterres Casses, em primoroso soneto, descreve um teclado ideal colocado nas alturas do Infinito entre as constelações. Sob a tênue luz do luar vai a criatura amada executar Verdi, Liszt, Mozart, Chopin e Beethoven. E o inesquecível autor de Stradivarius termina o seu admirável Plenilúnio com este terceto:

Num teclado ideal acordes tanges...

e... os pentágonos níveos das falanges

despetalam soluços de um noturno!... 
O geômetra sente-se encantado quando vê uma figura tão simples - como o pentágono - hachuriada pelas seduções e belezas da Poesia.

A Geometria, com suas figuras, relações e teoremas, não é, de forma alguma, infensa aos poetas. O Sr. Cassiano Ricardo, por exemplo, chegou ao extremo de inventar uma nova Geometria, que ele denominou Geometria Civil. É esse o título de um dos poemas. Destaquemos alguns versos do acadêmico e poeta paulista, colhidos em sua Geometria Civil:

Minha Geometria

É uma coisa viva

Feita de carne e osso.

Um ângulo quebrado

Logo escorre sangue.

Todo o meu futuro

É um retângulo obscuro.

Estes meus dois braços

São linhas paralelas

Que se cruzam em viagem

Para algum infinito.

E quem teria ensinado essa Geometria anti-euclidiana ao Sr. Cassiano Ricardo? Eis o que nos diz, a tal respeito, o próprio poeta:

\section{A Lua esfera fria}

Me ensinou em garoto,

A riscar bolas de ouro,

Sem compasso,

Na aula de Geometria.

E assim, cada poeta estabelece os postulados básicos de sua própria Geometria e se apresenta, aos olhos dos matemáticos, como um novo Lobatschewski, ou um novo Ricamann, a criar formar e espaços não compatíveis com os moldes euclidianos.

TAHAN, Malba. Matemática Divertida e Delirante 5. p. 57 e 58, 1962. 


\section{ANEXO F}

\section{Artigo: "As medidas de tempo na roça e na cidade"}

As unidades tradicionais de tempo (dia, hora, minuto e segundo) foram as únicas que, sem alterações, resistiram ao decorrer dos séculos.

$[\ldots]$

\section{TEMPOS QUE SE ALONGAM}

Para indicar intervalos maiores, emprega-se "uma hora bem puxada", "um tempão", "um século", etc.

Há também a "boa meia hora", que terá, certamente, mais de trinta minutos:

"Depois de ter andado dentro do mato, uma boa meia hora..." (Peregrino Júnior Matupá, p. 178)

Hora e meia designa, em geral, um tempo longo, quase interminável.

A expressão "que zano" ou "quizano" também é empregada para indicar muitos anos. Vejamos na primeira forma que zano:

"Sinhá prendeu a respiração para escutar bem.

- Ché! Esse um tá foi que zano!” (Ruth Guimarães - Água Funda, $2^{a}$ ed. p. 166)

$[\ldots]$

Para indicar uma idade superior a sessenta, porém inferior a setenta, pode-se usar a expressão "sessenta bem puxados":

“Ah! Não ter dez anos para menos, não viesse já os sessenta, bem puxados.” (H. Carvalho Ramos - Tropas e Boiadas, p. 51)

\section{AS HORAS DE SONO}

As horas de sono são contadas numa "advertência que muitas vezes ouvidos de nossos avós:

Cinco horas dorme o sábio,

Seis, o padre;

Sete, o operário;

Oito, o estudante;

Nove, o preguiçoso;

Dez, o porco,

Quem dormir mais está morto. 
Essa "advertência" é apresentada no Rifoneiro Português (p. 319), de Pedro Chaves, sob a seguinte variante:

Quatro horas dorme o santo,

Cinco o que não é tanto,

Seis o estudante,

Sete o caminhante,

Oito o porco,

Nove o morto.

E mais esta, que é bastante curiosa, em unidades menores:

Três horas dorme o santo,

Três e meia o que não é tanto;

Quatro o estudante,

Cinco o extravagante,

Seis o porco,

E sete o morto.

\section{HORINHAS E MINUTINHOS}

Emprega-se "horinha", para designar certo momento, determinando instante [...] Embora pareça incrível, é possível apreciar, sem auxílio de um cronômetro, o intervalo de meio minuto:

"Quando o índio sumiu, porta a fora, Teotônio, durante meio minuto, permaneceu parado.” (Abguar Bastos - Safra, 1937, p. 254)

Além do minuto, podemos tomar como unidade de tempo o minutinho: [...]

“José da Estação precipitou-se pela escada abaixo para ir buscar outra xícara:

- Um minutinho, compadre!” (Ribeiro Couto - Cabocla, São Paulo, 1931, p.18)

\section{RELATIVIDADE DE TEMPO}

Quando o escritor deseja salientar certo período de angústia ou de sofrimento, não toma como unidade o dia, mas sim a hora. Em vez de dizer "um dia de ansiedade, diz "vinte e quatro horas de ansiedade".

“Passeio quarenta e oito horas nessa agonia." (João Alberto Lins e Barros Memórias de um Revolucionário, p.83)

\section{PONTO}

O ponto era, antigamente, empregado como sinônimo de momento: 
“Que razão darei dos anos, dos dias, horas e pontos de minha vida?” (Amador Anaiz-Diálogos, p. 393)

$[\ldots]$

Sim, não resta dúvida. O tempo às vezes não pode ser contado:

“Ficaram ali meia hora? Uma hora? Eles não podiam contar o tempo.” (Dinah Silveira de Queiroz - A Muralha, 1954, p.423)

A exatidão, na hora, é assinalada pela expressão "em ponto". Dez em ponto, meianoite em ponto:

“O Aracati está com pressa. Ele tem de chegar ao 'Boqueirão de Lavras' à meianoite em ponto." (Santino Gomes de Matos - Oração dos Humildes, p.79)

\section{O SOL E A HORA}

A hora do dia, em linguagem literária, pode ser assinalada pela altura do Sol, medida em braças:

"Daquela vereda andei três léguas, chegando à distância cedo ainda, obra assim de braça e meia do Sol." (Simões Lopes Neto - Contos Gauchescos e Lendas do Sul, $3^{a}$ ed..p. 125)

Os poetas falam até nas "horas do meio-dia”:

"Dize-me ó tu, companheiro,

Do meu amor, nunca estranho:

Nas horas do meio-dia,

Aonde levas teu rebanho?"

(Freire Ribeiro - Cântico dos Cânticos, 1944, p.13)

\section{HORA H}

O momento certo, marcado, mais conveniente, ou mais oportuno, é chamado hora H. Hora que quem deve ocorrer algo de importante e grave. Momento delicado:

“E na hora ' $H$ ' era sempre lembrado... Só não podiam contar com ele [...] (Leônidas Bastos - O Prêmio, 1940, p. 65)

\section{HORA ZERO}

A hora da meia-noite em ponto assinala a hora zero.

TAHAN, Malba. Meu anel de sete pedras. $2^{\text {a }}$ ed; p. 134 a 142. Rio de Janeiro: Record. 1998. 


\section{ANEXO G}

Exemplo das fichas reduzidas do jogo "Memória dos relógios: analógico e digital"

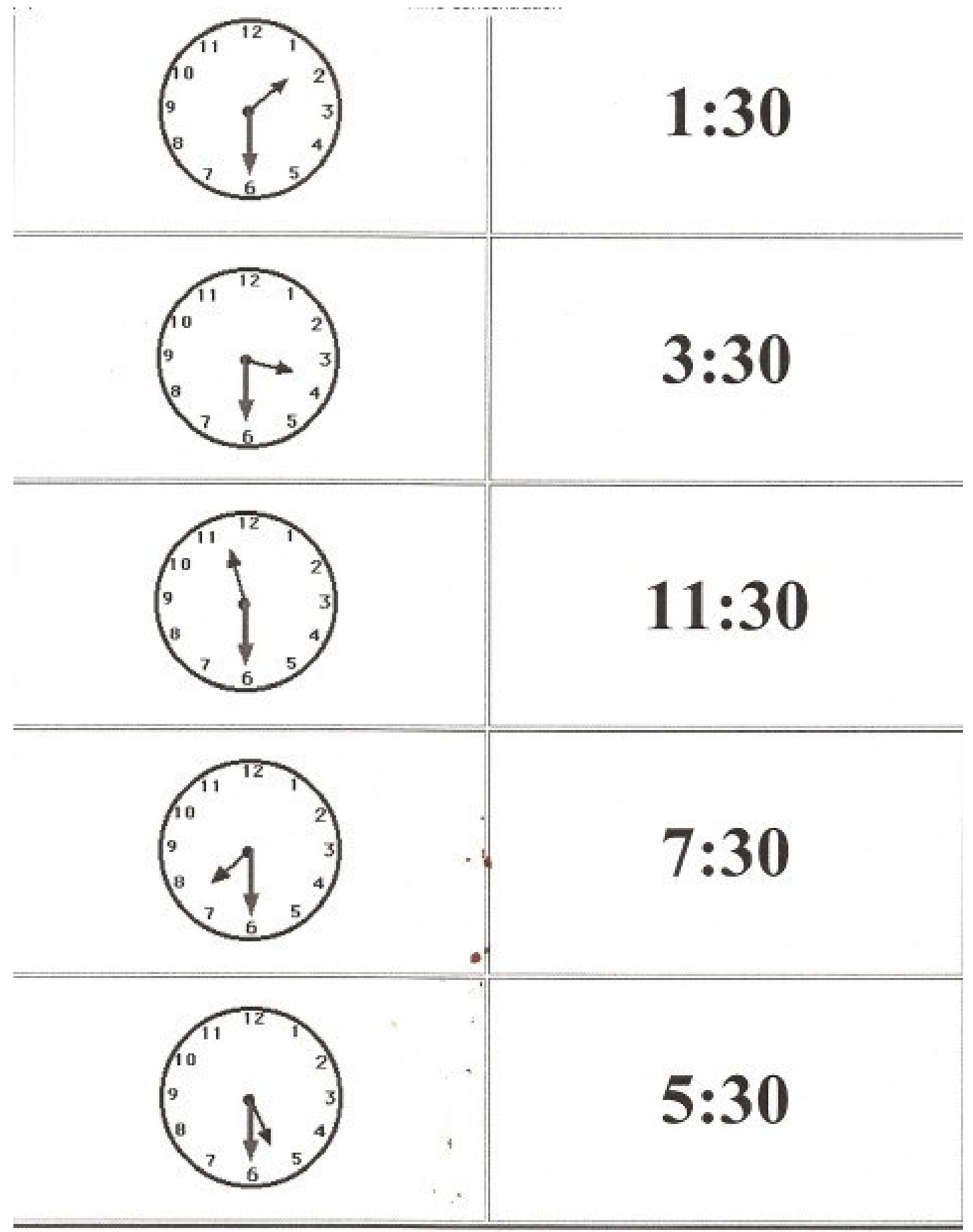


ANEXO H

\section{Artigo: "Dez, o número universal"}

\section{OS DEZ NAS PARLENDAS INFANTIS}

É muito conhecida, no interior do Brasil, uma parlenda que tem por título "A história da velha que tinha dez filhos". Aqui a apresentamos segundo uma versão que ouvimos em Queluz, de S. Paulo, da Sra. Joana Sene, residente naquela localidade:

"Era uma velha que tinha dez filhos, Todos dez dentro de um fole, Deu um tango-lo-mango num deles, Desses dez ficaram nove.

E esses nove, meu bem, que ficaram, Foram logo fazer biscoito,

Deu um tango-lo-mango num deles, Desses nove ficaram só oito.

E esses oito, meu bem, que ficaram, Foram brincar com canivete,

Deu um tango-lo-mango num deles, Desses oito ficaram sete.

E esses sete, meu bem, que ficaram, Foram à porta bater o trinco,

Deu um tango-lo-mando num deles, Desses seis ficaram cinco!

E esses cinco, meu bem, que ficaram, Com o diabo fizeram um trato, Deu um tango-lo-mango num deles, Desses cinco ficaram quatro!

E esses quatro, meu bem, que ficaram, Foram aprender o português,

Deu o tango-lo-mango num deles, Desses quatro ficaram três.

E esses três, meu bem, que ficaram, Foram ao campo buscar cem bois, Deu o tango-lo-mango num deles, Desses três ficaram dois!

Desses dois, meu bem, que ficaram, Foram ao mato caçar anum, Deu um tango-lo-mango num deles, E desses dois restou só um!

E esse um, meu bem, que ficou, Foi brincar com lampeão, Deu um tango-lo-mango no tal, E acabou-se a geração. 
$[\ldots]$

\section{OS DEZ MANDAMENTOS}

A palavra Decálogo, formada por dois vocábulos gregos deca (dez) e logos (palavra), é empregada para designar os dez mandamentos que Deus promulgou, para o seu povo, no monte Sinai:

Esses dez mandamentos são os seguintes:

1 - Amar a Deus sobre todas as coisas.

2 - Não jurar o seu santo nome em vão.

3 - Guardar domingos e festas.

4 - Honrar pai e mãe.

5 - Não matar.

6 - Não pecar contra a castidade.

7 - Não furtar.

8 - Não levantar falso testemunho.

9 - Não desejar a mulher do próximo.

10 - Não cobiçar as coisas alheias.

Os três primeiros mandamentos prescrevem os deveres do homem para com Deus; os sete outros alertam sobre os nossos deveres para com o próximo.

$[\ldots]$

\section{O DEZ NA POESIA}

Eis uma trova popular citada por Afrânio Peixoto:

"Subi às portas das nuvens,

Cavalgando um trovão,

Desci nas cordas das chuvas,

Com dez coriscos na mão.”

O poeta Correia Júnior também incluiu o número dez numa de suas trovas:

"É bem pobre o teu destino,

Meu coração sonhador; 
De Dor, noventa por cento,

E dez, apenas, de Amor!...”

$[\ldots]$

\section{O DEZ NOS PROVÉRBIOS}

Em alguns provérbios encontramos os dados ou contas totalizando dez. Eis alguns exemplos:

$[\ldots]$

Aquele que conta dez amigos não tem nenhum.

O verdadeiro amigo é joia rara. A soma de dez amigos dá sempre (segundo ensina esse provérbio) um total igual a zero.

Quem nasceu para dez-réis não chega a tostão.

Alusão à pessoa fraca, sem ânimo, que não tem energia para subir na vida, que não quer melhorar de situação. Existe implícita nesta frase uma nuvem de fatalismo. O destino vem do berço, é inexorável. Estava escrito (Maktub!) Se uma pessoa nasceu para viver pobre, sem recursos, isto é, se nasceu para dez-réis (ou derréis), não chegará jamais a valer o tostão (cem réis).

\section{O DEZ NAS GÍRIAS}

Entre as expressões populares vamos encontrar a seguinte:

Não paga dez!, para exprimir certeza, afirmação segura, caso que não deixa dúvida. Citemos um exemplo:

Alguém diz:

"Hoje à tarde vai chover. Não paga dez!"

Em outras palavras: "Afirmo que de tarde vai chover, com certeza. Não vale a pena apostar."

Sei contar até $\mathbf{d e z}$ - advertência empregada, entre os cariocas, quando uma pessoa deseja fazer sentir que não se deixa enganar, que não é tola: "Vender esse carro, meu amigo? Nem me fale nisso! Sei contar até dez!"

Dar grau dez - elogiar, exaltar, considerar ótimo. [...

Dez ou doze - expressão de fartura, abundância; muitos ou muitas a escolher. [...] 


\section{ANEXO I \\ Conto: "A glória do sapo"}

Vou contar uma história muito bonita.

Nela aparece, entretanto, um animal que é muito feio. Sabem qual é?

É o sapo!

Era uma vez um sapo chamado Balão. Esse sapo vivia embaixo de uma pedra.

Um dia o Balão viu passar perto dele um soldado com o peito cheio de medalhas.

E que lindas medalhas!

Duas eram de ouro, muito amarelinhas, e as outras eram de prata, com barras azuis e fitinhas vermelhas.

O Balão pensou: "Como arranjar uma bela medalha redonda como o Sol?

O Balão foi consultar sua boa amiga, a Dona Coruja.

Disse a Dona Coruja:

- Para ganhar uma bela medalha, nada mais simples. Há três ou quatro dias, o Rei mandou dar duas medalhas de ouro a uma artista que cantou no teatro.

- Ora, ora! - exclamou, alegre, o sapo. - Se a coisa depende de belas cantorias, nada mais simples: pode deixar o caso por minha conta. Isso de cantar forte e bonito, é comigo. Outra coisa não faço a noite inteira junto ao brejo em que vivo.

E sabem o que fez o sapo?

Vejam só.

Escondeu-se muito quietinho, sem que ninguém o visse, no jardim do Rei e durante a noite, quando a Lua rolava pelo céu, ele começou a cantar com a sua voz rouca e monótona.

- Uãaan! Dôoosis! Uãaan! Dôoosis! Têm! Têm! Têm-não-têm.

No dia seguinte os guardas do palácio, por ordem do Rei, puseram o sapo, aos pontapés, para fora do jardim.

Muito triste, por causa do fiasco da sua cantoria desentoada, o sapo foi, novamente, procurar a Dona Coruja e queixou-se do castigo que o haviam feito sofrer.

- Aquela gente - disse o Balão - não sabe apreciar os bons cantores.

É possível que a rainha seja mais bondosa. - retorquiu a Dona Coruja. - Sei de uma dançarina que recebeu uma linda medalha cheia de rubis, só pelo fato de ter dançado diante dela.

- Em matéria de dança eu sou um colosso, replicou o sapo. - Vou deslumbrar a rainha com meus novos bailados!

E, com o fim de agradar a bondosa soberana, o sapo escondeu-se debaixo de uma folha justamente no caminho em que ela deveria passar.

Quando a rainha acompanhada de suas damas-de-honra, vinha, muito elegante, fazer o seu passeio habitual, o sapo - záz! - saiu do seu refúgio e pôs-se a pular no meio da estrada.

Ao ver o sapo Balão, a rainha quase desmaiou de susto. As damas fugiram de medo. Houve uma gritaria medonha.

Um guarda, que perto se achava, veio logo em socorro das formosas princesas e deu várias chicotadas no sapo!

Com o corpo dolorido das pancadas, recolheu-se muito triste à sua casa. 
Ao passar perto do rio, ouviu dois patos conversando. Um dos patos (que parecia ser o mais velho) dizia:

- Sabe, amigo, que amanhã vai haver uma grande festa no palácio? Esta festa será em homenagem ao sapo! Ao sapo Balão!

- Ao sapo Balão?! - exclamou o outro - Que fez o sapo para merecer homenagem?

O pato velho explicou:

- O sapo Balão é um grande benfeitor de todos. É o sapo que come esses bichinhos terríveis que destroem as plantações. É o sapo Balão que defende, dia e noite, as nossas hortas e pomares.

E o pato concluiu:

- Penso que até o Rei devia dar uma linda medalha ao sapo! E seria muito justo!

Ao ouvir tais palavras o sapo ficou bastante comovido, e voltou muito contente para casa.

Não era cantando ou pulando que ele poderia conquistar a estima dos homens, mas sim praticando o bem e vivendo em paz.

Faça, pois, cada um, o bem que puder, pois só pela prática do bem é que as criaturas serão felizes e estimadas por todos.

O sapo é feio, mas é útil aos homens.

TAHAN, Malba. A arte de ler e contar histórias. Rio de Janeiro, 1961. P. 134 a 137. 


\section{ANEXO J \\ Artigo: "Unidades curiosas na arte culinária brasileira"}

Passemos a estudar, rapidamente, as principais unidades de medida da arte culinária brasileira, apresentando-as em ordem alfabética:

BOCADO: Porção indeterminada de certo ingrediente cujo peso varia de acordo com a receita. Há o bocado pequeno e bocadinho.

$[\ldots]$

CÁLICE: Unidade de capacidade equivalente, aproximadamente, a $50 \mathrm{~cm}^{3}$. Cálice de vinho.

COLHER: Unidade de capacidade muito variável, mas de emprego comuníssimo. Uma colher de açúcar, pesa, aproximadamente, $39 \mathrm{~g}$. O submúltiplo usado é a meia colher. São também de emprego frequente: a colher bem cheia (uma boa colher) e a colher mal cheia. [...] A porção contida numa colher é denominada uma colherada. A colherada é, portanto, uma espécie de unidade de uso corrente. [...]

COLHER DE CAFÉ: Colher pequenina. Tem um submúltiplo: meia colher de café. [...]

COLHER DE CHÁ: Colher de pequenas dimensões. Aparece também na prática a meia colher de chá.

COLHER DE SOPA: Para se obter a colher de sopa rasa é só passar a lâmina da faca pela colher de sopa cheia, fazendo com que seu conteúdo fique nivelado com as bordas. Uma colher de sopa rasa de açúcar pesa dez gramas, aproximadamente.

COLHERINHA: O mesmo que colher de café.

CONCHA: Unidade de capacidade equivalente a $90 \mathrm{~cm}^{3}$, aproximadamente. Há duas conchas: a de açucareiro e a de sopa. Esta última vale, em capacidade, cinco vezes a primeira.

COPO: Unidade de capacidade para líquidos. Equivalente a $270 \mathrm{~cm}^{3}$. É também empregado o meio copo. [...]

CUIA: Unidade de capacidade para farinha. É também usada a meia cuia. Equivale a cinco litros ou cinco tigelas bem calculadas. [...] Podemos citar o provérbio "Lavar-se em água de cuia", que significa "ser feliz", "venturoso na vida". A água de cuia era água limpa e fresca. [...] 
DEDAL: Unidade de capacidade de emprego em cidades do interior do Brasil. Fora da arte culinária, vamos encontrar o dedal na avaliação de certas porções de miçangas. $\mathrm{O}$ dedal equivale, aproximadamente, a $3 \mathrm{~cm}^{3}$.

FATIA: Porção indeterminada de pão, presunto, salame, etc. Fatia grossa e fatia fina [...]

FOLHAS: Essa unidade é empregada na avaliação de gelatina, que é, pelo comércio, vendida em porções denominadas folhas. Usa-se a meia, a folha pequena, ou a folhinha: folhinha de louro, folhinha de hortelão.

GALHO: Porção pequena de salsa. Há também o galhinho de agrião.

GOTA: Unidade empregada na medida de líquidos e equivale a $3,5 \mathrm{~mm}^{3}$, aproximadamente. [...]

LATA: Há certos produtos que são vendidos em lata. A lata, para muitos produtos, apresenta-se como unidade de capacidade. Encontramos, também, a meia lata e a latinha. Observação: a antiga lata de querosene foi, durante muitos anos, adotada como unidade. [...] Em algumas cidades do interior do Brasil, o milho e o feijão eram medidos em latas (latas de querosene).

MOLHO: Feixe pequeno. Molho de espinafre, molho de agrião, etc. [...]

MONTINHO: Porção pequena. Grandeza indeterminada.

NADA: Porção muito pequena. Diz-se: "um nada de pimenta". Há também o "nadinha" que os doceiros admitem do mesmo modo que o nada. "Coloca-se, por fim, um nadinha de sal..."

PACOTE: O pacote é tomado como unidade, quando se trata de ingrediente que é vendido em pacotes. Há também o pacotinho (de creme de arroz) que pesa 200 gramas.

PEDAÇO: Medida não determinada. Parte relativamente pequena. [...] Em certas receitas aparece a expressão "um bom pedaço". Há também o pedacinho, que deve corresponder, aproximadamente, a uma quarta parte de um pedaço. [...]

PESO: Porção de carne suficiente para uma refeição. Carne bastante para um assado. Há o peso e o bom peso. [...]

PINGO: Pequena quantidade de um líquido. Equivale a duas ou três gotas. O povo admite pingos de todos os tamanhos. Há pingos tão grossos que afogam um passarinho. [...]

PIRES: Unidade empregada para avaliar o açúcar, a farinha, etc. Um pires de açúcar equivale a 130 gramas. No Norte do Brasil, um pires é empregado para medir quantidade de jabuticabas, de mangabas, etc.

PITADA: Porção de certa substância (geralmente pó) que pode ser apanhada com o auxílio do indicador e do polegar: pitada de sal [...] 
PRATO: É também usado como unidade de medidas de capacidade. Há três tipos: prato de sobremesa, prato raso e prato fundo. [...] Convém não esquecer do "prato cheio". [...]

PUNHADO: Porção que cabe, sem esforço, na mão: punhado de arroz, punhado de sal, etc.

RAMINHO: As receitas às vezes prescrevem: um raminho de salsa; um raminho de hortelã na canja.

RODELA: Porção (em forma cilíndrica) de pão, de abacaxi [...]

SALPICO: Quantidade equivalente a três ou quatro gotas. [...]

TALHADA: Porção indeterminada. Os autores citam a meia talhada e a talhadinha: talhada de limão, talhada de melancia, etc.

$[\ldots]$

XÍCARA: Unidade de capacidade que deriva exprimir o conteúdo de uma xícara de chá de tamanho médio. Além de xícara (de chá), são empregadas: a xícara rasa, a xícara cheia, a xícara mal cheia, a xícara de café e a xicrinha. São também usadas: a meia xícara, 1/4 de xícara e 3/4 de xícara. [...] A xícara mal cheia de açúcar pesa 100 gramas; uma xícara rasa de açúcar, pesa 125 gramas. [...]

TAHAN, Malba. Meu anel de sete pedras. $2^{\text {a }}$ ed; p. 108 a 121. Rio de Janeiro: Record. 1998. 


\section{ANEXO K}

\section{TEXTO DRAMÁTICO:}

O NARIZ DO REI MAHENDRA (Lenda do Cáucaso)

\section{PERSONAGENS:}

$>$ Narrador (Amigos)

$>$ Rei Mahendra

$>$ Pintor (a) Meryem

$>$ Pintor Kedar

$>$ Pintor Fauzi Nalik

NARRADOR - Era uma vez um rei muito estúpido, que tinha um nariz torto, monstruoso, horrível. Não percebia, porém, o pobre monarca, a enormidade do seu defeito; julgava-se, ao contrário, um verdadeiro tipo de beleza masculina. Infeliz daquele que zombasse, ou de leve se referisse ao narigão disforme do rei! Punha a língua à mostra na forca mais próxima!

NARRADOR - Um dia o Rei Mahendra disse ao ministro:

REI MAHENDRA - Quero ter aqui, no palácio, um retrato meu, cuja perfeição e fidelidade todos hajam de gabar.

NARRADOR - O ministro mandou chamar os melhores pintores do país. O prêmio ao mais hábil era magnífico: um elefante, um palácio e uma caixa cheia de joias.

NARRADOR - Apresentaram-se três artistas que passavam por habilíssimos: Kedar, pintor da corte; Meryem, de origem árabe e o jovem Fauzi Nalik, sírio de grande talento. Kedar, tomando da tela, fez surgir de sob seus ágeis pincéis, um retrato perfeito do rei; reproduziu o nariz do monarca exatamente como o modelo lhe mostrava - enorme e monstruoso. Quando o rei Mahendra viu a sua figura grotesca, nitidamente, reproduzida no quadro, ficou furioso: 
REI MAHENDRA - Atrevido! Miserável! Fazer de mim semelhante mostrengo!

NARRADOR - E mandou enforcar o pintor.

NARRADOR - Meryem, o segundo artista, ao ver o triste fim de seu companheiro achou prudente não imitar a escola realista de seu malogrado colega. Isto de pintar os soberanos tal como eles são deu sempre mau resultado. E o árabe retratou o rei fazendo-o perfeito em todos os seus traços fisionômicos. Era aquilo uma verdadeira obra de arte.

NARRADOR - Enfureceu-se ainda mais o monarca ao ver o novo trabalho. A figura feita por Meryem era bela, e em nada se parecia com o original, de nariz singularmente feio.

REI MAHENDRA - (Gritando) Esse pintor quer zombar de mim! Esse retrato em nada se parece comigo! É, antes, um verdadeiro escárnio.

NARRADOR - E mandou enforcar o infeliz Meryem.

NARRADOR - Chegou, finalmente, a vez do jovem Fauzi Nalik, o pintor sírio.

PINTOR FAUZI NALIK - Estou perdido! Se pinto o rei de nariz torto vou para a forca; se lhe endireito a cara, sou enforcado!

NARRADOR - E todos na cidade já lhe lamentavam, por antecipação, o triste fim. "No dia em que ele der o último retoque no retrato do Rei, vai direitinho levar o pescoço ao braço!" Mas - com espanto geral - tal não aconteceu. O monarca ficou encantado com o trabalho do talentoso Fauzi Nalik.

REI MAHENDRA - Este, sim! Este é o meu verdadeiro retrato. 
NARRADOR - E mandou que sem mais demora se entregasse ao moço pintor a prometida e valiosa recompensa: um elefante, um palácio e uma caixa de joias.

NARRADOR - Quando Fauzi Nalik, radiante e feliz, deixou o palácio real, viu-se cercado dos amigos que o cumulavam de perguntas:

(NARRADOR - AMIGOS) - Então? Como conseguiste o milagre? Pintaste o rei de nariz torto ou sem nariz? Conta-nos lá a proeza.

PINTOR FAUZI NALIK - Pois vou contá-la. Pintei o Rei exatamente como ele é. Tive, porém, a ideia de imaginá-lo a caçar tigres, e a arma que ele levava ao rosto tapava-lhe perfeitamente o nariz grotesco e monstruoso! (Afastando-se, risonho) Se o aleijão do Rei Mahendra, ao invés de ser no nariz, fosse nas pernas, eu o teria pintado a banhar-se num lago com água até à cintura.

Texto narrativo disponível em:

TAHAN, Malba. “O nariz do Rei Mahendra” in Maktub. 1954, p. 31-34. 


\section{ANEXO L \\ TEXTO DRAMÁTICO: \\ O HOMEM MARAVILHOSO}

\section{PERSONAGENS:}

Bibliotecário (Narrador 1)

Bibliotecário (Narrador 2)

Bibliotecário (Narrador 3)

Ajudante que distribuía os livros

Homem maravilhoso (homenzinho da roupa cinzenta; misterioso sábio)

BIBLIOTECÁRIO (NARRADOR 1) - Todos os dias, às 4 horas da tarde, invariavelmente, entrava na Biblioteca o homenzinho da roupa cinzenta. Trazia já na mão o pedido do livro que desejava ler: "História da Groenlândia". Recebido o compêndio, escrito, aliás, em norueguês, lá ia ele, muito sossegado, sentar-se numa das poltronas, no fundo do salão, e ficava a ler a obra, até que a sineta, às dez horas, com seu toque estridente, anunciasse que a Biblioteca ia fechar-se. Um dos empregados, que trabalhava comigo na distribuição dos livros, chamou a minha atenção para o fato:

AJUDANTE QUE DISTRIBUÍA OS LIVROS - Quem será esse homem misterioso que lê, todos os dias, durante seis horas, uma complicada história da Groenlândia, escrita em norueguês?

BIBLIOTECÁRIO (NARRADOR 2) - No talão em que ele requisitava o livro, vinha apenas uma assinatura vaga, duvidosa: R. S. Slady. É um pseudônimo, com certeza. Esse homem da roupa cinzenta deve ser um sábio notável, preocupado com algum estudo sobre as origens dos esquimaus...

BIBLIOTECÁRIO (NARRADOR 3) - Certo dia, porém, surgiu ele com um novo pedido. Queria ler o tratado do dr. Riemann, naturalista alemão, intitulado: “A respiração nos escaravelhos". Fiquei seriamente intrigado. O homem abandonava, de repente, o 
estudo que vinha fazendo sobre a Groenlândia e passava a ler um livro sobre a "respiração dos escaravelhos"! Quem seria esse cidadão que procurava ler apenas as obras que ninguém lia?

BIBLIOTECÁRIO (NARRADOR 1) - Durante quatro meses não leu o misterioso sábio outra coisa senão o pesadíssimo compêndio do dr. Riemann. Um dia, porém, pondo de lado os famosos insetos, entrou com o pedido de um livro que ainda mais nos assombrou: "Gramática descritiva e completa da língua chinesa", pelo professor Fo-Hang-Lu, de Pequim.

BIBLIOTECÁRIO (NARRADOR 2) - É uma enciclopédia. Dedica-se ao estudo minucioso de diversos assuntos. Naturalmente está preparando, agora, um artigo magistral, para a Revista da Academia, sobre os verbos irregulares chineses.

BIBLIOTECÁRIO (NARRADOR 3) - O meu maior desejo era encontrar, fora da Biblioteca, aquele sábio extraordinário e modesto, que se dedicava, com tanta assiduidade, a estudos tão elevados.

BIBLIOTECÁRIO (NARRADOR 1) - Certa vez, quando eu vinha para o trabalho, encontrei, casualmente, junto do cais, absorvido em profundas meditações, o misterioso leitor dos escaravelhos e da gramática chinesa. Aproximei-me dele, saudei-o com o máximo respeito e disse-lhe: "Tenho acompanhado com o maior interesse, os importantes estudos que v. ex. vem fazendo, há mais de um ano, na Biblioteca. Desejo saber, apenas, em que revista ou jornal acadêmico publica v. ex. os seus artigos, naturalmente originais e substanciosos.

HOMEM MARAVILHOSO (homenzinho da roupa cinzenta; misterioso sábio) (Com um sorriso resignado e bom) Ah! Meu caro senhor! Não leio, não estudo, nem escrevo coisa alguma! Vou todos os dias à Biblioteca Pública unicamente para dormir!

BIBLIOTECÁRIO (NARRADOR 2) - Dormir?!

HOMEM MARAVILHOSO (homenzinho da roupa cinzenta; misterioso sábio) - É a pura verdade. Frequento a Biblioteca apenas para dormir! Sou pobre e sem família; vivo com muita dificuldade; sou obrigado a trabalhar a noite inteira. Durante o dia, à falta de 
outro cômodo, onde possa dormir com mais conforto, vou descansar os ossos na poltrona macia do salão de leitura!

BIBLIOTECÁRIO (NARRADOR 3) - Se é só para dormir, por que pede livros sobre assuntos tão complicados?

HOMEM MARAVILHOSO (homenzinho da roupa cinzenta; misterioso sábio) (Risonho) Eu mesmo não sei o que peço. Para que me seja permitido ficar no salão de leitura, devo pedir um livro qualquer. Requisito sempre o livro indicado no primeiro cartão do catálogo. Quando mudam o catálogo, ou a ordem dos cartões, peço, sempre então, sem o querer, um novo livro! Para mim, qualquer livro serve. Tenho sempre tanto sono!

Texto narrativo disponível em:

TAHAN, Malba. O homem maravilhoso in Maktub. 1954, p. 103 a 106. 


\section{ANEXO M \\ TEXTO DRAMÁTICO: \\ O COLECIONADOR DE COINCIDÊNCIAS}

\section{PERSONAGENS:}

$>$ Narrador 1

$>$ Narrador 2

$>$ Grande Matemático

$>$ Colecionador de Coincidências (Dr. Samuel Spaier; Visitante)

$>$ Homem de cinzento-claro

NARRADOR 1 - O grande matemático fechou, lentamente, o livro. Pousou, com cuidado, a pena junto do tinteiro e, voltando-se para o inesperado visitante que permanecia de pé, disse-lhe:

GRANDE MATEMÁTICO - Sente-se, por favor. De que se trata, afinal? Algum novo problema?

NARRADOR 2 - O homem da pasta amarela deixou-se cair, pela ação da gravidade, na larga e confortável poltrona. Teria cinquenta anos no máximo; alto magro, de uma magreza retilínea, quase vertical. Trazia óculos cor de cinza com aros vermelhos. Pura esquisitice, com certeza...

COLECIONADOR DE COINCIDÊNCIAS (Dr. Samuel Spaier) - (Voz de constrangimento) Venho consultá-lo sobre um novo e importante problema de Matemática. Trata-se, apenas, de determinar uma fórmula geral que permita medir uma coincidência qualquer!

GRANDE MATEMÁTICO - Coincidência? Como assim? 
COLECIONADOR DE COINCIDÊNCIAS (Dr. Samuel Spaier) - (Animado) Em poucas palavras poderei explicar-lhe. Devo confessar que coleciono coincidências. Sim, senhor. Não se admire. Sou, repito, colecionador de coincidências. Há milhares de pessoas pelo mundo que colecionam coisas; uns, selos; outros, borboletas; outros, enfim, cartões, plantas exóticas, carteirinhas de cigarro, moedas, móveis antigos, penas, aranhas, autógrafos, cachimbos, cartões-postais, quadros, livros, pedras preciosas e até múmias! Há coleções incríveis! Conheci em Paris um maestro, muito rico, que colecionava "risadas"; essa original "coleção" era gravada em discos especiais; em cada disco figurava o nome, a idade e, às vezes, até a biografia do autor da "risada". Não acha interessante?

GRANDE MATEMÁTICO - Interessantíssimo!

COLECIONADOR DE COINCIDÊNCIAS (Dr. Samuel Spaier) - Pois bem. Para fugir à vulgaridade resolvi organizar uma coleção única no mundo, isto é, uma coleção de coincidências. Ao ter notícia de uma coincidência notável, procuro todos os meios de comprová-la. Uma vez obtidos os necessários documentos, a coincidência passa a figurar no meu álbum rigorosamente assinalada a custo de fotografias, recortes de jornais, depoimentos de testemunhas idôneas, etc. Eis um exemplo que poderia apontar entre centenas de outros. No dia 5 de março deste ano, na Praça de S. Luís, um automóvel, que conduzia um passageiro atropelou um transeunte descuidado; um médico, que passava no momento, socorreu o ferido e um guarda, postado de serviço no local, prendeu o motorista desastrado. Houve, nesse caso, uma coincidência realmente notável, já devidamente incluída em minha coleção. O médico, o guarda, o ferido, o passageiro e o "chauffeur", esses cinco cavalheiros envolvidos no acidente, faziam anos precisamente naquele dia 5 de março. Notável, não acha? Tenho, a tal respeito, várias fotografias autênticas e certidões com firmas reconhecidas.

GRANDE MATEMÁTICO - É curioso.

COLECIONADOR DE COINCIDÊNCIAS (Dr. Samuel Spaier) - Isto ainda não é nada. Não me furto ao prazer de contar-lhe mais uma. Em setembro de 1919 (não me recordo precisamente do dia) partiu de Dover um pequeno vapor, o "Moldan", com um carregamento de fios. Tomaram passagem apenas quatro viajantes. Ocorreu, então, uma coincidência de pasmar. Os quatro passageiros eram pernetas, sendo dois a perna direita e os outros dois da esquerda. A esse respeito tenho duas grandes fotografias, numa das quais figura o comandante do "Moldan" com uma blusa de couro, ladeado pelos passageiros estropiados! Ora, senhor matemático, a minha coleção só terá realmente interesse para o grande público no dia em que eu puder classificar as coincidências que nela figuram, segundo certo critério, isto é, atribuindo a cada uma delas determinado valor. Posso provar 
que há coincidências suscetíveis de comparação. Chamo-me Samuel Spaier, sou médico e tenho 1m,71 de altura. Vamos supor que, ao atravessar uma rua, esbarre com um indivíduo qualquer. Se esse indivíduo se chamar Samuel, houve no nosso encontro uma certa coincidência; se ele, porém, além de se chamar Samuel, for médico, a coincidência será maior; se o sujeito, médico e Samuel, tiver precisamente $1 \mathrm{~m}, 71$ de altura, a coincidência observada será cem mil vezes maior. Ora, se há coincidências maiores e outras menores, é claro que cada uma delas exprime, dentro das leis do Acaso, uma certa grandeza e como qualquer grandeza pode ser avaliada, isto é, expressa por um número...

GRANDE MATEMÁTICO - Perfeitamente. A medida de uma coincidência poderá ser feita, com relativa facilidade, com auxílio da famosa teoria das Probabilidades, aplicandose os três teoremas ou princípios de Poincaré. É preciso, entretanto, não confundir uma "coincidência aparente", resultante forçada e natural de circunstâncias bem determinadas. Uma ocorrência qualquer pode, em verdade, deixar em nosso espírito a impressão de ter sido presidida por uma coincidência quando nela, afinal, o Acaso não colaborou. Assim, por exemplo, no caso do vapor "Moldan" que, tendo partido do Dover no dia 11 de setembro de 1919, conduzia quatro pernetas, segundo fui informado por uma reportagem do "Times", não houve coincidência, alguma...

COLECIONADOR DE COINCIDÊNCIAS (Dr. Samuel Spaier) - Como assim?

GRANDE MATEMÁTICO - Tratava-se, apenas, segundo pude averiguar, de quatro mutilados de guerra que eram, por ordem do governo, enviados para uma clínica especializada... No encontrarem-se ali os quatro pernetas não houve, portanto, a menor interferência do Acaso!

COLECIONADOR DE COINCIDÊNCIAS (Dr. Samuel Spaier) - (Muito sério) Estranho interesse tornou o senhor por esse caso. Teria sido mera casualidade?

GRANDE MATEMÁTICO - Asseguro que não. Sei que vou surpreendê-lo e talvez mesmo contrariá-lo. Vejo-me, porém, forçado a confessar a verdade. Sou também, há vários anos, colecionador de coincidências.

NARRADOR 1 - Nenhuma outra notícia poderia causar tão dolorosa surpresa ao Dr. Spaier. Sentiu-se aniquilado. Via desaparecer, num relance, o título mais valioso de sua 
coleção: a originalidade. Tudo perdido! O Dr. Spaier, sem dizer palavra, ergueu-se nervoso, agitado e retirou-se precipitadamente da sala.

NARRADOR 2 - Ao sair, porém, esbarrou violentamente com um homem de cinzentoclaro que, exatamente naquele momento, atravessava o patamar. Com o choque rolam ambos, numa queda fatal e tremenda pela escada do apartamento. Verificou-se depois que o tal homem de cinzento-claro chamava-se Samuel, era médico e tinha $1 \mathrm{~m}, 71$ de altura. Essa coincidência, porém, o Dr. Spaier não pôde mais incluí-la em sua coleção.

Texto narrativo disponível em:

TAHAN, Malba. O colecionador de coincidências in Maktub. 1954, p. 71 a 76. 


\author{
ANEXO N \\ TEXTO DRAMÁTICO \\ O VENDEDOR DE CONSELHOS
}

\title{
PERSONAGENS:
}

\author{
Narrador 1 \\ Narrador 2 \\ CHEIK-EL-MEDDAH (Chefe dos contadores de histórias dos cafés) \\ VENDEDOR DE CONSELHOS (homem de barba preta)
}

Filhos

NARRADOR 1 - É tão estranho e singular o caso que vou narrar que pode parecer, aos que ainda não me conhecem, que sou movido pelo desejo de fugir à verdade. Tomo Allah como testemunha. Caia sobre mim, se assim o merecer, o castigo tremendo com que a Divina Justiça costuma punir os mentirosos.

E o Cheik-el-meddah depois de arrancar da cabeça o turbante desbotado, começou:

CHEIK-EL-MEDDAH (Chefe dos contadores de histórias dos cafés) - Ao regressar certa tarde de uma excursão ao oásis, de Boachir, nos arredores de Damasco, avistei, num canto deserto da rua Aychi, sob a luz bruxuleante de um candeeiro, um homem de barba preta, modestamente vestido. É um mendigo. Tenho, como bom homem, um dever a cumprir: a esmola. Aproximei-me, pois, do desconhecido e, quando ia depositar-lhe na mão o meu modesto óbulo, fui surpreendido por um gesto de recusa:

VENDEDOR DE CONSELHOS (homem de barba preta) - Obrigado, meu amigo. Não peço esmolas, e ainda não cheguei ao extremo de estender a mão à caridade pública. Deus é grande! Ganho honestamente a minha vida vendendo conselhos!!!

CHEIK-EL-MEDDAH (Chefe dos contadores de histórias dos cafés) - Vendendo conselhos! Custa-me acreditar que possa alguém ganhar a vida vendendo uma mercadoria já secularmente desvalorizada! Nas mesquitas, nos bazares, nas praças e nas estradas acotovelamos, a cada momento, indivíduos que outra coisa não fazem senão ministrar 
conselhos aos que se dão ao desfastio de ouvi-los. E esses conselheiros eventuais consideram-se generosamente pagos com um pouco de atenção da parte de seus ouvintes. Farias melhor negócio, ó venerável conselheiro, se te resolvesses a vender areia aos beduínos no deserto!

VENDEDOR DE CONSELHOS (homem de barba preta) - Agradeço a tua sugestão, ó cheique! Já vejo que gostas de dar conselhos a quem não os pede. [...] não proporciono os meus ensinamentos de graça; procuro, ao contrário, vendê-los sempre por bom preço. Segue em paz o teu caminho. Se querer prosperar tranquilo evita as provocações inúteis!

$[\ldots]$

CHEIK-EL-MEDDAH (Chefe dos contadores de histórias dos cafés) - Dou-te cinco dinares por um bom conselho. Serve-te o negócio?

VENDEDOR DE CONSELHOS (homem de barba preta) - Aceito-o! Convém-me o teu preço. Presta bastante atenção nas minhas palavras. O meu conselho é o seguinte: Quando vires um, desconfia de três; quando vires três, desconfia de um!"

CHEIK-EL-MEDDAH (Chefe dos contadores de histórias dos cafés) - (De bom humor) É profundo demais o teu ensinamento, e não chego a compreendê-lo. Acho-o até bastante obscuro, quase enigmático!

VENDEDOR DE CONSELHOS (homem de barba preta) - (Com azedume) O sentido de certas palavras só a inteligência viva de quem os ouve pode esclarecer. Mais vale seguir um bom conselho sem compreender, do que tudo compreender para não seguir! Paga-me os trinta dinares que me deves e deixa-me em paz!

CHEIK-EL-MEDDAH (Chefe dos contadores de histórias dos cafés) - (Surpreso) Trinta dinares! Se os teus conselhos forem tão desarrazoados como os teus preços, malservidos estarão os teus fregueses! Que conta é essa afinal? Eu prometi apenas cinco dinares! 
VENDEDOR DE CONSELHOS (homem de barba preta) - Sim, combinamos o preço de cinco dinares. Lembra-te, porém, de que eu já te dei, depois que aqui chegaste, seis conselhos sábios e úteis, e cada um deles no valor de cinco dinares. Vou recordá-los. Primeiro: "Segue em paz o teu caminho". Segundo: "Se queres viver tranquilo evita provocações". Terceiro: "Presta bastante atenção em minhas palavras". Quarto: "Quando vires um, desconfia de três; quando vires três, desconfia de um". Quinto: "Mais vale seguir um bom conselho sem compreender do que tudo compreender para não seguir". Sexto e último: "Paga-me os trinta dinarse que deves e deixa-me em paz!" Estás vendo agora que eu tenho razão; são ao todo trinta dinares!

CHEIK-EL-MEDDAH (Chefe dos contadores de histórias dos cafés) - (Irritado) Isto é uma exploração ignóbil! A tua mesma demência não justifica semelhante extorsão! Já vai longe a tua audácia, ó chacal! Não pago coisa alguma!

VENDEDOR DE CONSELHOS (homem de barba preta) - (Com voz soturna) Queres, ó insensato, zelar pela integridade de teus ossos e conservar a tua vida? Espia, então, por cima desse muro.

NARRADOR 2 - O Chefe dos contadores de histórias dos cafés, trepou numa pedra e olhou para o outro lado do tal muro. Avistou, com surpresa, três homens que pareciam verdadeiros bandidos, armados como os salteadores das estradas, e que dormiam descuidados. Puxou o vendedor de conselhos pelo braço e explicou:

CHEIK-EL-MEDDAH (Chefe dos contadores de histórias dos cafés) - (Com voz rouca e lenta): Esses jovens são meus filhos e meus auxiliares diretos. Cada um deles tem mais de quinze mortes na consciência e de tudo darão contas a Deus! A um sinal meu, eles não hesitarão em reduzir a frangalhos o pagamento dos meus sábios conselhos. Eu, aliás, bem te avisei: "Quando vires um desconfia de três". Estás vendo, agora, aqueles três latagões decididos? Desconfia de um que sou eu!

NARRADOR 1 - Diante daquela ameaça e do grave perigo em que o chefe dos contadores de histórias dos cafés se achava, não quis discutir com o miserável salteador. Tirou da bolsa trinta dinares e atirou as moedas aos pés do intrujão. 
VENDEDOR DE CONSELHOS (homem de barba preta) - Agora já são quarenta e não trinta. A tua memória é ingrata. Já esqueceste os dois últimos e maravilhosos conselhos que dei? "Espia, então, por cima desse muro!" e "Desconfia de um que sou eu!"

CHEIK-EL-MEDDAH (Chefe dos contadores de histórias dos cafés) - Pago. Pago, mas que ladrão!

NARRADOR 2 - E o chefe dos contadores de histórias dos cafés desatou a fugir, antes que o vendedor de conselhos oferecesse novos conselhos a peso de ouro.

CHEIK-EL-MEDDAH (Chefe dos contadores de histórias dos cafés) - [...] O tempo não me fará esquecer os terríveis conselhos pelos quais sacrifiquei o meu ouro para poupar minha vida: "Segue em paz o teu caminho". "Se queres viver tranquilo evita as provocações inúteis". E ainda mais: "Quando vires um, desconfia de três"; quando vires três, desconfia de um". Paguei bem caro, é verdade, mas isso não impede que hoje eu os dê de graça a todo mundo. Uassalã!

Texto narrativo disponível em:

TAHAN, Malba. O vendedor de conselhos in Maktub. 1954, p. 48 a 54. 
ANEXO O

\section{TEXTO DRAMÁTICO:}

\section{O PROBLEMA DOS 35 CAMELOS}

\section{PERSONAGENS:}

Narrador (Amigo de Beremis)

Beremis (o homem que calculava)

Irmãos Namir (Namir, Hamed Namir e Harim Namir - 3 herdeiros dos camelos)

NARRADOR (Amigo de Beremis) - Poucas horas havia que viajávamos sem interrupção, quando nos ocorreu uma aventura digna de registro, na qual meu companheiro Beremis, com grande talento, pôs em prática as suas habilidades de exímio algebrista. Encontramos perto de um antigo caranvançará meio abandonado, três homens que discutiam acaloradamente ao pé de um lote de camelos. Por entre pragas e impropérios gritavam possessos, furiosos:

NAMIR - Não pode ser!

HAMED NAMIR - Isto é um roubo!

HARIM NAMIR - Não aceito!

NARRADOR (Amigo de Beremis) - O inteligente Beremis procurou informar-se do que se tratava.

NAMIR - Somos irmãos e recebemos, como herança, esses 35 camelos. Segundo a vontade expressa de meu pai, devo receber a metade, o meu irmão Hamed Namir uma terça parte e ao Harim, o mai moço, deve tocar apenas a nona parte. Não sabemos, porém, como dividir dessa forma 35 camelos e a cada partilha proposta, segue-se a recusa dos outros dois, pois a metade de 35 é 17 e meio. Como fazer a partilha se a terça parte e a nona parte de 35 também não são exatas? 
BEREMIS - É muito simples. Encarrego-me de fazer, com justiça, essa divisão, se permitirem que eu junte aos 35 camelos da herança, este belo animal que, em boa hora, aqui nos trouxe!

NARRADOR (Amigo de Beremis) - Não posso consentir semelhante loucura! Como poderíamos concluir a viagem, se ficássemos sem o camelo?

BEREMIS - (Com voz baixa) Não te preocupes com o resultado, ó bagdali! Sei muito bem o que estou fazendo. Cede-me o teu camelo e verás no fim a que conclusão quero chegar.

NARRADOR (Amigo de Beremis) - Tal foi o tom de segurança com que ele falou que não tive dúvida em entregar-lhe o meu belo "jamal", que imediatamente, foi reunido aos 35 ali presentes, para serem repartidos pelos três herdeiros.

BEREMIS - (Dirigindo-se aos três irmãos) Vou, meus amigos, fazer a divisão justa e exata dos camelos que são agora, como veem, em número de 36.

BEREMIS - (Voltando-se para o mais velho dos irmãos) Deverias receber, meu amigo, a metade de 35, isto é, 17 e meio. Receberás a metade de 36 e, portanto, 18. Nada tens a reclamar, pois é claro que saíste lucrando com esta divisão!

BEREMIS - (Dirigindo-se para o segundo herdeiro) E tu, Hamed Namir, deverias receber um terço de 35 , isto é, 11 e pouco. Vais receber um terço de 36 , isto é, 12 . Não poderás protestar, pois tu também saíste com visível lucro de transação.

BEREMIS - (Dirigindo-se para o irmão mais moço) E tu, jovem Harim Namir, segundo a vontade de teu pai, deverias receber uma nona parte de 35, isto é, 3 e tanto. Vais receber uma nona parte de 36 , isto é, 4 . O teu lucro foi igualmente notável. Só tens a agradecer-me pelo resultado! 
BEREMIS - (Concluindo) Pela vantajosa divisão feita entre os irmãos Namir couberam 18 camelos ao primeiro, 12 ao segundo e 4 ao terceiro, o que dá um resultado $(18+12+4)$ de 34 camelos. Dos 36 camelos, sobram, portanto, dois. Um pertence, como sabem, ao bagdáli, meu amigo e companheiro, outro toca por direito a mim, por ter resolvido, a contento de todos, o complicado problema da herança!

NAMIR - Sois inteligente, ó estrangeiro! Aceitamos a vossa partilha na certeza de que foi feita com justiça e equidade!

NARRADOR (Amigo de Beremis) - E o astucioso Beremis tomou logo posse de um dos mais belos "jamales" do grupo e disse-me entregando-me pela rédea o animal que me pertencia:

BEREMIS - Poderás agora, meu amigo, continuar a viagem no teu camelo manso e seguro! Tenho outro, especialmente para mim!

NARRADOR (Amigo de Beremis) - E continuamos nossa jornada para Bagdá.

Texto narrativo disponível em:

TAHAN, Malba. O problema dos 35 camelos in Antologia da Matemática (1 $\left.{ }^{\circ}\right)$; p. 17 a 19. 


\section{ANEXO P}

\section{Avaliação Diagnóstica Final de Matemática}

Você está participando de uma Avaliação Diagnóstica, com o objetivo de avaliar suas habilidades e conhecimentos adquiridos até o momento. Faça com atenção e sem pressa, demonstrando tudo o que você sabe. Boa Prova!

Instruções:

3.A Prova só contempla questões de múltipla escolha.

4.Para cada uma das questões há quatro alternativas e somente uma deve ser assinalada. A marcação em mais de uma alternativa anula a questão.

1) (SAEB/PROVA BRASIL/2009) A figura 1 a seguir representa a planificação da figura 2, o cubo.

Figura 1

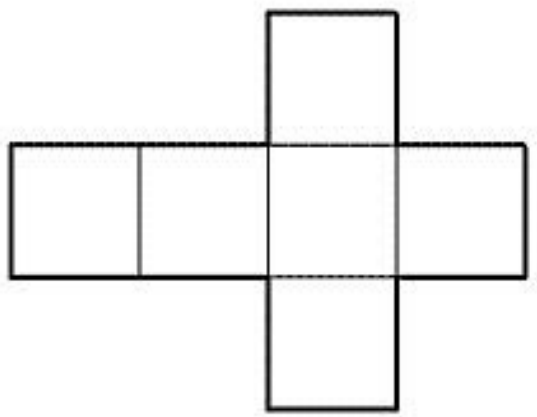

Figura 2

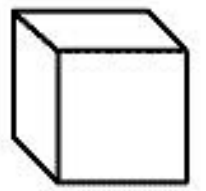

Com base na planificação da figura 2, podemos dizer que um cubo possui:
(A) 4 faces
(B) 3 faces
(C) 8 faces
(D) 6 faces 
2) (SARESP/2012) Em uma sala de aula com 30 alunos, 1/3 deles prefere Matemática,1/2 prefere Geografia e os demais não têm preferência por matéria alguma. Nessa sala, o número de alunos que não têm preferência por matéria alguma é:
(A) 3
(B) 5
(C) 7
(D) 8

3) (PROVA BRASIL/2011) No ábaco abaixo, Cristina representou um número:

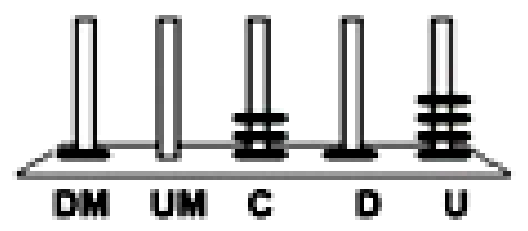

Qual foi o número representado por Cristina?
(A) 1.314
(B) 4.131
(C) 10.314
(D) 41.301

4) (PROVA BRASIL/2013) O brinquedo de João está do seu lado esquerdo. Qual é o brinquedo preferido de João?

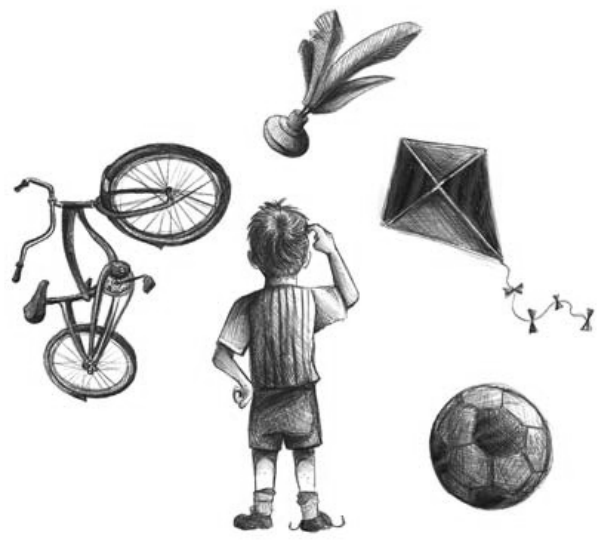
(A) Peteca
(B) Pipa
(C) Bola
(D) Bicicleta 
5) (PROVA BRASIL/2013) Chegando a uma cidade, Fabiano visitou a igreja local. De lá, ele se dirigiu à pracinha, visitando em seguida o museu e o teatro, retornando finalmente para a igreja. Ao fazer o mapa do seu percurso, Fabiano descobriu que formava um quadrilátero com dois lados paralelos e quatro ângulos diferentes.

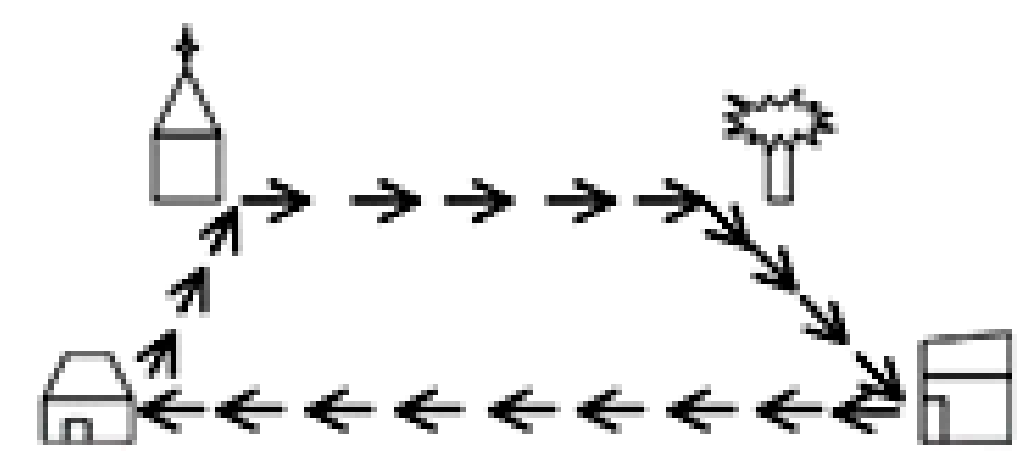

TEATRO

MUSEU

O quadrilátero que representa o percurso de Fabiano é um:
(A) quadrado.
(B) losango.
(C) trapézio.
(D) retângulo.

6) (SAEB/PROVA BRASIL/2009) Caio percorreu 3000 metros de bicicleta em 30 minutos. Quantos quilômetros $(\mathrm{km})$ ele percorrerá em 1 hora?
(A) $6 \mathrm{~km}$
(B) $9 \mathrm{~km}$
(C) $60 \mathrm{~km}$
(D) $90 \mathrm{~km}$

7) (SARESP/2012) Entre os itens abaixo, aquele em que as grandezas envolvidas são proporcionais é:
A) a idade de uma pessoa e sua altura.
(B) a quantidade de queijo que uma pessoa compra e o valor em dinheiro que paga pela compra.
(C) a velocidade de um carro e a quantidade de passageiros que ele transporta.
(D) numa partida de futebol, a quantidade de gols marcados e o tempo transcorrido. 
8) (SARESP/2013) O gráfico abaixo mostra a quantidade de pontos feitos pelos times A, B, $\mathrm{C}$ e D no campeonato de futebol da escola. De acordo com o gráfico, quantos pontos o time $\mathrm{C}$ conquistou?

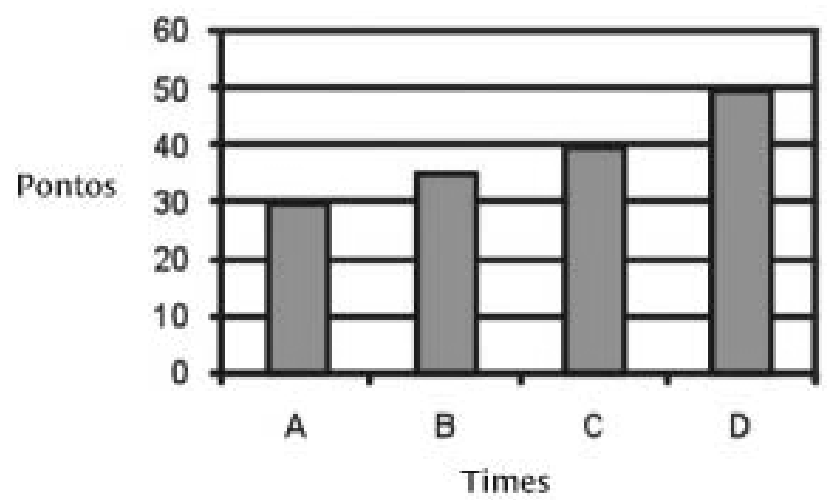
(A) 50
(B) 40
(C) 35
(D) 30

9) (SARESP/2013/adaptada) Uma professora do $5^{\circ}$ Ano pediu que uma aluna marcasse numa linha do tempo o ano de 1940.

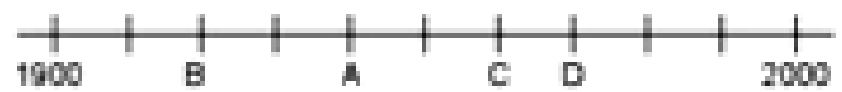

Que ponto a aluna pode marcar para acertar a tarefa pedida?
(A) A
(B) $\mathrm{B}$
(C) $\mathrm{C}$
(D) $\mathrm{D}$

10) (SAEB/PROVA BRASIL/2009) Em uma cesta há 21 laranjas e na outra há 13 laranjas. Quantas laranjas devem ser passadas de uma cesta à outra para que as duas fiquem com a mesma quantidade de laranjas?
(A) 2
(B) 3
(C) 4
(D) 5 


\section{ANEXO Q}

Gabaritos das Avaliações Diagnósticas

\begin{tabular}{|c|c|c|}
\hline QUESTÃO & $\begin{array}{c}\text { Avaliação Diagnóstica } \\
\text { Inicial }\end{array}$ & $\begin{array}{c}\text { Avaliação Diagnóstica } \\
\text { Final }\end{array}$ \\
\hline 01 & D & D \\
\hline 02 & D & B \\
\hline 03 & B & C \\
\hline 04 & C & D \\
\hline 05 & D & A \\
\hline 06 & C & B \\
\hline 07 & C & B \\
\hline 08 & A & A \\
\hline 09 & C & C \\
\hline 10 & D & \\
\hline
\end{tabular}




\begin{abstract}
ANEXO R
Partilhas de Experiências Matemáticas Interdisciplinares: Matemática, Língua Portuguesa, Arte, Ciências, História e Geografia
\end{abstract}

Partilha de Experiência Matemática Interdisciplinar dos $1^{\text {os }}$ Anos A e B

$\underline{\text { A Matemática de Malba Tahan e a Matemática da Rede Salesiana de Escolas }}$

\title{
"Tabuleiro de tampinhas"
}

\section{Objetivo Geral:}

- Trabalhar a identificação e correspondência entre números/quantidades e contagem a partir do jogo tabuleiro das tampinhas.

\section{Objetivos Específicos:}

- $\quad$ Respeitar e obedecer as regras;

- Trabalhar em grupo e respeitar o colega;

- Identificar quantidade no dado;

- $\quad$ Fazer contagem das tampinhas;

- Relacionar quantidade do dado com quantidade de tampinhas;

- $\quad$ Completar o tabuleiro com as tampinhas a cada jogada.

\section{Tempo/Período:}

- 1 ou mais aulas de matemática, semanalmente;

- $\quad$ Período da tarde;

- $\quad$ Público-alvo: $1^{\text {os }}$ anos A e B.

\section{Recursos/materiais}

- 1 tabuleiro para cada aluno,

- 40 tampinhas para cada criança,

- $\quad 1$ ou 2 dados por dupla.. 


\section{Estratégias/Desenvolvimento}

Para realizar a brincadeira, as crianças se organizam em duplas e cada criança recebe: um tabuleiro, um dado e 40 tampinhas de garrafa pet. Para iniciar o jogo, decide-se quem será o primeiro a jogar, depois cada um por sua vez joga o dado e coloca sobre o tabuleiro o número de tampinhas conseguido no dado. Vence quem completar primeiro o seu tabuleiro.

\section{$\underline{\text { Avaliacão }}$}

Acreditamos que os jogos na Matemática são importantes para o desenvolvimento social e intelectual da criança. $O$ jogo tabuleiro das tampinhas auxiliou no desenvolvimento de habilidades, como: observação, análise, levantamento de hipóteses, busca de solução e argumentação, o que está diretamente relacionado ao raciocínio lógicomatemático.

Foi um momento de muita alegria, descontração e aprendizagem.

\section{Partilha de Experiência Matemática Interdisciplinar do Infantil I A e B}

\section{Matemática na Educacão Infantil - Classificacão de objetos}

\section{Justificativa:}

$\checkmark$ O conhecimento lógico-matemático não se dá por informação, mas pela possibilidade da criança interagir e a partir dessa relação conhecer a nomenclatura específica e formar conceitos. O concreto, assim como o lúdico, é imprescindível no processo de aprendizagem.

\section{Objetivos:}

Estabelecer relações de semelhança e de agrupamento, utilizando critérios diversificados para classificar, seriar e ordenar coleções;

Quantificar elementos de uma coleção, utilizando diferentes estratégias; 
$\checkmark \quad$ Comunicar as quantidades, utilizando a linguagem oral, para construção de palavras que definam conceitos matemáticos.

$\checkmark$ Trabalhar simultaneamente o conceito e a noção de "dentro e fora".

\section{Tempo / Período:}

$\checkmark$ Inicialmente, dois dias, podendo a atividade ser feita outras vezes, com variações;

$\checkmark$ Período da tarde;

$\checkmark$ Público-alvo: Infantil I A e I B (2 anos).

\section{Recursos / Materiais:}

$\begin{array}{ll}\checkmark & \text { Brinquedos e objetos de diferentes tamanhos e cores; } \\ \checkmark & \text { Caixas encapadas ou cestos com tamanhos diferenciados; } \\ \checkmark & \text { Figuras pré-selecionadas correspondente a tamanhos diferentes, cores, etc. }\end{array}$

\section{Estratégias / Desenvolvimento:}

$\checkmark \quad$ Utilizando brinquedos de diferentes tamanhos realizamos a classificação com as crianças do Infantil I A e B, trabalhando sempre o concreto para a assimilação e compreensão visual e oral da criança;

$\checkmark$ Com objetos de variados tamanhos, classificar em grupos distintos. Exemplo: Maior e Menor. Também se podem classificar quanto às cores, formas geométricas; a percepção visual novamente estará em foco nesta atividade.

\section{Avaliação:}

$\checkmark$ A avaliação na Educação Infantil deve partir do observar e compreender o dinamismo presente no desenvolvimento infantil. (Observar se os conceitos foram construídos ou estão em construção).

$\checkmark$ Formativa.

Partilha de Experiência Matemática Interdisciplinar dos $2^{\text {os }}$ Anos A e B 
Justificativa: O cálculo é aprendido junto com a noção de número e a partir do seu uso em jogos, brincadeiras e situações-problema, nas quais as crianças calculam, com o apoio em diferentes recursos, quais sejam dedos, lápis, e papel, material manipulativo e outros. Além desse apoio, propomos que as crianças, com o tempo, passem a realizar alguns cálculos por meio da estimativa e do cálculo mental.

\section{Objetivos:}

- Trabalhar concentração e ritmo;

- Estimular o aluno a realizar estimativas e verificar resultados;

- Criar momentos com desafios;

- Realizar a soma, neste caso através das pedras;

- Comparar resultados com os dos outros;

- Comunicar a solução por meio de registros e comunicação oral;

- Tornar a aula de matemática lúdica e prazerosa.

Desenvolvimento: A sala deverá se agrupar em círculo onde cada criança deverá ter em mãos uma caixinha com uma pequena quantidade de pedras.

A professora explicará que irão cantar a música "Escravo de Jó".

\section{Escravos de Jó}

Escravos de Jó jogavam caxangá.

Tira. Põe. Deixa ficar...

Guerreiros com guerreiros fazem zigue-zigue-zá.

Guerreiros com guerreiros fazem zigue-zigue-zá

Ao ouvirem a música, todos do grupo fazem o movimento com a caixinha. Ao acabar, realizam em duplas a estimativa da contagem das pedrinhas e logo após montam a adição na folha e registram a contagem. 
Intervenções: As crianças vão falar quem chegou mais perto da estimativa e comparar o maior número e o menor, podendo realizar uma sequência em ordem crescente e/ou decrescente, após o registro que a professora poderá fazer na lousa.

Tempo: Esta atividade poderá ser realizada nas aulas de matemática, no período de aula.

Público alvo: Crianças dos $2^{\text {os }}$ anos: A e B.

\section{Recursos/ Materiais:}

- Caixinhas pequenas.

- Pedrinhas ou tampinhas de garrafa. (Selecionamos pedrinhas, pois estabelecemos uma ligação com as rochas nas aulas de Ciências onde estamos fazendo uma coleção);

- Folha para o registro do cálculo.

Avaliação: A avaliação ocorre por meio da observação da brincadeira durante a participação das crianças na contagem das pedrinhas e em relatos sobre as intervenções que a professora irá promover.

\section{Bibliografia:}

PCN de Matemática (Ciclo 1).

Livro da RSE de Matemática $-2^{\circ}$ ano do EF.

\section{Partilha de Experiência Matemática Interdisciplinar do Infantil I C e D}

TEMA: Classificação e seriação de blocos lógicos.

\section{JUSTIFICATIVA:}

O trabalho com blocos lógicos, em atividades que exigem da criança a manipulação, auxilia o desenvolvimento de habilidades de discriminação e memória visual, constância de forma e tamanho, sequência e simbolização. Também auxilia os alunos a classificarem formas, ou seja, juntá-las por semelhanças ou separá-las por diferenças. A classificação é uma estrutura lógica que, no caso da geometria, está relacionada à formação das noções do que são as figuras geométricas e de suas propriedades. Por exemplo, quando 
a criança é capaz de separar o quadrado das outras figuras, ela executou a ação de classificar e estabeleceu observações sobre as características dessa figura que a distinguem das demais.

Nesse sentido, é importante explorar os blocos na educação infantil, pois, além desse material permitir um trabalho com classificação, ele pode dar início ao reconhecimento e nomeação de figuras geométricas, já que é um modelo visual para as crianças.

\section{OBJETIVO GERAL:}

Favorecer a aprendizagem das crianças por meio de atividades lúdicas, ampliando seu repertório quanto às cores, formas e localização espacial.

\section{OBJETIVOS ESPECÍFICOS:}

- Explorar diferentes objetos para comparar formas, tamanhos e cores;

- Reconhecer e nomear as cores;

- Desenvolver a capacidade de observação;

- Explorar e identificar propriedades geométricas de objetos e figuras;

- Desenvolver a coordenação viso-motora;

- Desenvolver o raciocínio lógico;

- Explorar e classificar as formas dos blocos lógicos;

- Ampliar o repertório oral.

\section{TEMPO DE DURAÇÃO:}

Para o desenvolvimento de todas as atividades foram necessárias 10 aulas.

\section{PÚBLICO ALVO:}

Crianças de 3 anos de idade ou a completar.

\section{DECURSOS MATERIAIS:}

- Blocos Lógicos

- Papel pardo

- Tinta guache

- Rolinho para pintura 
- Papel A3

- Cola

- Figuras recortadas em papel colorido

- Fita crepe

\section{ESTRATÉGIAS/DESENVOLVIMENTO}

Foram realizadas várias atividades envolvendo a manipulação dos blocos lógicos, onde as crianças precisavam classificá-los por cor e forma.

Exemplos de atividades desenvolvidas: sacola surpresa, reizinho mandou, formas no chão com fita crepe, colagem de formas, pintura com rolinho, etc...

\section{AVALIAÇÃo}

Foi realizada mediante a observação do professor, levando em consideração o envolvimento e interesse das crianças nas atividades desenvolvidas.

\section{BIBLIOGRAFIA}

Livro Caleidoscópio (3 anos) - Manual do professor

RCNEI

\section{Partilha de Experiência Matemática Interdisciplinar dos $3^{\text {os }}$ Anos A e B}

\section{Tema:}

- Observando e criando, sob os diferentes pontos de vista dos sólidos geométricos.

\section{Justificativa:}

A partir do trabalho realizado no Eixo laranja, sobre sólidos geométricos e pontos de vista, tal atividade foi elaborada levando em consideração o conhecimento adquirido na formação de professores, visando despertar o interesse dos alunos nas propostas do Eixo Espaço e Forma, uma vez que este não é tão aprofundado, de modo geral, como números e operações.

\section{Objetivo Geral:}

- Desenvolver a capacidade de observar e criar, identificando os sólidos geométricos e relacionando as formas que estes apresentam em diferentes pontos de vista. 
- Analisar os sólidos geométricos a partir dos diferentes pontos de vista;

- $\quad$ Explorar a criatividade;

- $\quad$ Ampliar o vocabulário matemático e estruturar o texto corretamente (descrição);

- Identificar as propriedades dos sólidos geométricos.

\section{Tempo de duração:}

- O desenvolvimento das atividades aconteceram em 5 aulas.

\section{Público-alvo:}

- Alunos dos $3^{\text {os }}$ anos do Ensino Fundamental I.

\section{Recursos Materiais:}

- $\quad$ Sólidos Geométricos;

- $\quad$ Caixas, garrafas, latas, tubos e outros materiais com os formatos trabalhados;

- $\quad$ Folha em formato de livro, lápis e lápis de cor.

\section{Desenvolvimento:}

Utilizando as embalagens trazidas pelos alunos foi montada uma mesa para observação a partir dos diferentes pontos de vista.

Organizamos uma tabela pedindo para que os alunos escolhessem 3 embalagens e relacionassem com as figuras/sólidos geométricos (construção coletiva na lousa).

\section{Criando:}

A partir das observações individuais cada aluno criou a sua figura e a descreveu, nomeando corretamente.
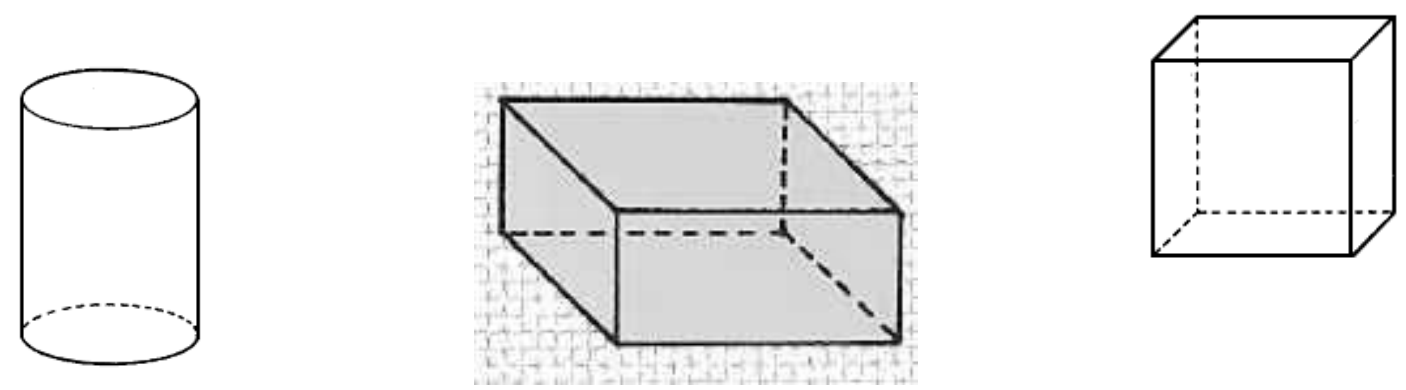

Avaliação: Realizada durante as atividades em sala de aula, com observações e registros feitos pela professora. Também ocorrerá na Avaliação Trimestral do $1^{\circ}$ Trimestre. 


\section{Partilha de Experiência Matemática Interdisciplinar do Infantil II A e B Professoras Sílvia Barker e Juli Elen Reis}

“Na Matemática, para saborear com prazer o fruto é preciso conhecer bem as suas raízes.”

(Malba Tahan)

TEMA: "Interdisciplinaridade Matemática: Caleidoscópio e Projeto de Leitura”.

\section{JUSTIFICATIVA:}

A interdisciplinaridade é uma "exigência" não somente no que tange às atividades escolares, mas também às práticas do dia a dia com as quais frequentemente nos deparamos. O mundo encontra-se em constantes e aceleradas mudanças. As tecnologias de comunicação integram povos de diferentes partes do mundo em questão de segundos, e para lidar com essa nova fase, decorrente de um mundo globalizado, precisamos saber integrar as diversas concepções e realidades. Esta integração deve complementar as diversas disciplinas e a possibilidade de acesso à pesquisa, motivando o educando e o educador a buscarem novos conhecimentos sobre um determinado assunto, problema ou questão.

Antes de abordar o tema interdisciplinaridade e suas facetas é preciso primordialmente conhecer sua origem etimológica:

\footnotetext{
A palavra interdisciplinaridade é formada por três termos: inter - que significa ação recíproca, ação de A sobre B e de B sobre A; disciplinar - termo que diz respeito à disciplina, do latim discere - aprender, discipulus - aquele que aprende e o termo dade - corresponde à qualidade, estado ou resultado da ação. (O mundo da Saúde, 2006, p. 107-116).
}

Segundo Fazenda (apud CARLOS S. D), a interdisciplinaridade surgiu na França e na Itália em meados da década de 1960 do Século XX, em meio a reivindicações estudantis favoráveis a inserção dela na resolução dos problemas políticos, sociais e econômicos, na educação, a fim de que pudessem ajudar a solucioná-los da melhor forma. Foi assim que surgiu o conceito de interdisciplinaridade, pois estava relacionado a diversas áreas do conhecimento.

No século XX, ao final da década de 1960, o conceito de interdisciplinaridade, chega também ao Brasil influenciando, posteriormente, na elaboração de leis que regem a 
educação brasileira, tais como: a Lei de Diretrizes e Bases (LDB - Lei $n^{\circ}$ 9394/96) e os Parâmetros Curriculares Nacionais (PCN), tendo como precursores Hilton Japiassu e Ivani Fazenda. Apesar de sua grande influência/importância, não existem definições e terminologias exatas acerca do termo interdisciplinaridade, cabendo a cada estudo a elaboração das definições, podendo ser interpretadas de acordo com as situações a que foram submetidas para análise. Para Japiassu (apud FAZENDA, 2002, p. 25): “A interdisciplinaridade caracteriza-se pela intensidade das trocas entre os especialistas e pelo grau de integração real das disciplinas no interior de um mesmo projeto de pesquisa".

Por tais definições escolhemos a interdisciplinaridade para ser a base de nossa apresentação.

Mais em: $\underline{\text { http://www2.unemat.br/revistafaed/content/vol/vol_16/artigo_16/95_114.pdf }}$

\section{OBJETIVO GERAL:}

Mostrar por meio desta apresentação que é possível relacionar as atividades de um Projeto de Leitura com as atividades, conceitos e conteúdos de uma apostila - Caleidoscópio (RSE).

\section{OBJETIVOS ESPECÍFICOS:}

- Tratar a matemática como parte de um todo, usando metodologias diferenciadas para seu ensino - jogos e atividades práticas;

- Trabalhar paralelamente atividades do Projeto de Leitura e do Caleidoscópio;

- Levar ao conhecimento dos alunos conhecimento novos, como gráficos, jogos de trilha, contagem e regras.

\section{> TEMPO DE DURAÇÃO:}

Nossa partilha matemática foi trabalhada durante um mês, em 10 aulas. Esta proposta continuará a ser aplicada no decorrer do $1^{\circ}$ semestre/2015.

\section{PÚBLICO ALVO:}

Alunos do Infantil II A e B, com idade de 4 anos.

\section{RECURSOS MATERIAIS:}

- Papel; 
- Dados;

- Tabuleiro (já vem no anexo do aluno);

- Marcadores (tampinhas ou formas de E.V.A.);

- Papel pardo com os eixos já prontos (para a confecção dos gráficos);

- Marcadores para o gráfico (quadrados de papel colorido);

- Caixa de papelão encapada (caixa surpresa);

- Objetos aleatórios para se colocar dentro da caixa.

\section{ESTRATÉGIAS/DESENVOLVIMENTO:}

No decorrer das atividades propostas do caleidoscópio, na área de matemática, bem como nas demais, fomos inserindo atividades do Projeto de Leitura: A Arca de Noé.

Utilizamos a atividade "Caixa Surpresa", onde se iniciou a motivação do Projeto de Leitura, atividades em folha e práticas referentes aos Eixos de Movimento, Natureza e Sociedade, Artes, Linguagem Oral e Escrita e Matemática (foram desenvolvidas no decorrer dos dias).

Uma atividade lúdica também sugerida pelo Caleidoscópio e que se encaixou muito bem em nosso Projeto foi a "Corrida do Bichos", um jogo de trilha ao qual os alunos são levados a contar, recontar quando estão na trilha, respeitar as regras, observar os resultados e responder às perguntas. Esta atividade foi aplicada 4 vezes em nossa sala, e ainda continuará a ser aplicada, em cada nova participação o aluno encontra um novo conhecimento, sempre sendo relembrados os anteriores.

Este jogo serviu como base para a elaboração de um gráfico de colunas, onde por meio da observação os alunos responderam perguntas, analisaram dados e assim 'aprenderam' ações relativas ao campo tratamento da informação.

\section{$\checkmark$ ATIVIDADES / JOGOS APRESENTADOS:}

\section{- “Caixa Surpresa”.}

Este jogo consiste na adivinhação de um objeto que está dentro da caixa.

No Caleidoscópio é sugerida com o objetivo de resolver problemas de forma oral, fazendo com que a criança tente descobrir o que está dentro da caixa por meio de perguntas. 
"Cada vez que o professor solicita que a criança diga o que fez e o porquê, verbalize os procedimentos que adotou, relate suas reflexões pessoais, permitindo que o aluno modifique seus conhecimentos prévios, reflita sobre o que fez e elabore significados para as ideias e procedimentos matemáticos envolvidos na situação trabalhada.”

- “Corrida dos Bichos".

Esta atividade está sugerida no Caleidoscópio. Pede-se que seja aplicada mais de uma vez.

É um jogo de trilha, vamos precisar de um tabuleiro, um dado e marcadores.

Divide-se a sala em grupos, cada grupo receberá o material acima, depois de decidir quem será o primeiro, o aluno deve jogar o dado contar e cobrir o número de casas na pista usando os marcadores.

1- exploração do tabuleiro.

2- depois de jogar, faça uma roda de conversa sobre o mesmo. O professor pode orientar a conversa através de perguntas:

- Qual animal chegou primeiro?

- Foi legal? Foi chato? Você gostou?

\section{AVALIAÇÃO}

A avaliação é e será realizada diariamente, a partir da interação e participação dos alunos nas atividades propostas.

\section{BIBLIOGRAFIA}

- Caleidoscópio - RSE.

- BRASIL. Ministério da Educação e do Desporto. Secretaria de Educação Fundamental. Referencial Curricular Nacional para a Educação Infantil. Brasília: MEC/SEF, 1998.

- Artigos e textos retirados da Rede Internet.

\section{Partilha de Experiência Matemática Interdisciplinar dos $4^{\text {os }}$ Anos A e B Professoras Márcia Reis e Cristiana Rodrigues}

\section{TRABALHANDO COM GRANDEZAS E MEDIDAS}

A matemática, senhora que ensina o homem a ser simples e modesto, 
é a base de todas as ciências e de todas as artes. (Malba Tahan, 1938)

Do ponto de vista pedagógico, temos nesta obra um exemplo admirável: nela Malba Tahan, ao mesmo tempo que elucida conceitos e teorias sobre a história infantil, apresenta orientações fundamentadas em sua experiência de contador de histórias, em domínio de auditório e em técnicas de contação de histórias. Aponta que "a finalidade precípua da história Infantil é divertir a criança, estimulando-Ihe a imaginação e a inteligência" (Tahan, 1964, p. 69) e que o professor, ao escolher uma história para ser lida, contada ou musicada em sala de aula, não pode esquecer de buscar atingir os objetivos da história infantil: educar, instruir, preparar a criança para uma certa atividade, desviá-la de uma corrente má de pensamentos, confortar a criança (caso da criança enferma), torná-la otimista para a vida, atender ao psiquismo infantil, atrair a criança para um ambiente sadio (biblioteca, sala de leitura, etc.) e ocupação agradável para as horas de lazer. Enfatiza ainda que "a história, bem escolhida e bem orientada, pode servir como viga-mestra na grande obra educacional" (Tahan, 1964, p. 15).

\section{Justificativa:}

A relevância do estudo das grandezas e medidas é apontada pela sua presença nas práticas sociais, a articulação com outros temas estudados na Matemática e em outras áreas do conhecimento e na prática de diversas profissões. Na verdade, medir e contar são atividades feitas todos os dias por quase todas as pessoas e, independente do grau de escolarização. As grandezas e medidas estão presentes em nosso cotidiano, mas, contraditoriamente, parece que não nos damos conta disso. Desde muito cedo, as crianças vivenciam situações em que é necessário medir, ao chegar à escola as crianças já trazem conhecimentos de situações que envolvem a comparação de grandezas em jogos e brincadeiras, como construir uma pipa e marcar distâncias em jogos de bolinha de gude.

Como os exemplos citados retratam práticas comuns de cidadãos em qualquer lugar do mundo, podemos afirmar que ao auxiliar na compreensão destes conteúdos pelos alunos estaremos contribuindo também para o exercício da cidadania.

- Considerando importante aproximar o ensino da matemática e o ensino da língua materna, percebemos que o trabalho com a matemática escolar seria enriquecido se pudesse ser feita uma conexão com a literatura infantil; e esta poderia ser um modo desafiante e lúdico para as crianças pensarem sobre algumas noções matemáticas. 
- Integrar literatura nas aulas de matemática representa uma substancial mudança no ensino tradicional, pois, em atividades desse tipo, os alunos não aprendem primeiro a matemática para depois aplicar na história, mas exploram a matemática e a história ao mesmo tempo.

\section{Objetivos Gerais:}

* Estimular reflexões e discussões sobre a Matemática e o cotidiano entre diferentes temas e ainda em relação à Matemática e às outras áreas do conhecimento, pois é possível estabelecer conexão entre o desenvolvimento do gosto pela leitura, produção de texto oral e escrito com as áreas de desenvolvimento matemático.

\section{Objetivos Específicos:}

*Identificar as unidades de medida de massa, comprimento, tempo e capacidade nas atividades cotidianas;

* Reconhecer a necessidade do uso das unidades medidas e saber como usá-las adequadamente;

* Estimular o gosto pela leitura, envolvendo situações matemáticas e produção de textos orais;

*Desenvolver a habilidade em experimentar para comprovar e argumentar suas escolhas.

\section{Desenvolvimento:}

Período de aplicação: 08 aulas.

\section{$1^{\text {a }}$ Etapa}

Os alunos serão estimulados a experimentar medidas de comprimento sem uso dos instrumentos convencionais, para isso usarão o próprio corpo (palmo, polegadas, passos, barbante, elástico e outras) medindo espaços e objetos do cotidiano.

Os alunos serão convidados a trazer alguns recipientes de formas e tamanhos diferentes que possam servir e acomodar líquidos e sólidos. Eles farão a classificação dos recipientes de acordo com a sua utilidade. As atividades relacionadas à medida de capacidade e volume serão iniciadas com o Livro da Rede Salesiana de Escolas. 
Os alunos participarão da Roda de Leitura com o livro tema da sequência didática que será "Os irmãos Gêmeos".

A Roda de Leitura será interativa, convidando os alunos a refletirem sobre possibilidades, estimando resultados e argumentando suas escolhas.

Algumas questões relacionadas à boa convivência entre irmãos, colegas e entre outras pessoas do nosso cotidiano também serão privilegiadas.

\section{$3^{\text {a }}$ Etapa}

Essa etapa será dedicada ao registro dos conhecimentos adquiridos durante as atividades, o registro servirá como uma ferramenta de resgate dos conceitos trabalhados e a sua sistematização.

Neste momento, as dúvidas que surgirão, questionamentos e afirmações deverão ser valorizados para que o avanço na atividade ocorra da melhor maneira possível.

\section{Avaliacão:}

- Durante todo o processo, avaliamos as estratégias de modo contínuo para o desenvolvimento social e intelectual dos alunos. Também, a avaliação foi feita mediante as provas mensais e trimestrais ocorridas no primeiro trimestre, observando aquilo que o (a) aluno (a) conseguiu entender e ocorrerá, ainda, no segundo trimestre;

- Levamos em conta os questionamentos levantados durante as aplicações das atividades propostas pelo livro da RSE.

\section{Partilha de Experiência Matemática Interdisciplinar do Infantil III A e B}

"POR TER ALTO VALOR NO DESESENVOLVIMENTO DA INTELIGÊNCIA E DO RACIOCÍNIO, É A MATEMÁTICA UM DOS CAMINHOS MAIS SEGUROS POR ONDE PODEMOS LEVAR O HOMEM A SENTIR O PODER DO PENSAMENTO E A MAGIA DO ESPÍRITO."(Malba Tahan, 1961)

TEMA: “TRILHA DAS FORMAS".

\section{$\checkmark$ JUSTIFICATIVA:}


"Nos jogos de regras, os jogadores estão, não apenas, um do lado do outro, mas juntos. (...). O conteúdo e a dinâmica do jogo não determinam apenas a relação da criança com o objeto, mas também suas relações em face a outros participantes do jogo. (...)"

“Assim o jogo de regras possibilita o desenvolvimento das relações sociais da criança".

Ainda, o jogo de tabuleiro é um meio de desenvolver habilidades: como observação, análise, levantamento de hipótese, busca de suposição, reflexão, tomada de decisão, argumentação e organização que estão estreitamente relacionados ao raciocínio lógico-matemático.

\section{OBJETIVOS:}

\section{GERAL:}

- Utilizar o jogo da trilha das formas como meio relevante para desenvolver a integração social e intelectual da criança.

\section{ESPECÍFICOS:}

- Oferecer possibilidades para o reconhecimento e apropriação das formas geométricas planas;

- Inserir e oferecer caminhos para apropriação dos números concomitantemente com a sequência numérica;

- Desenvolver o raciocínio lógico-matemático, por meio da verificação dos pontos que aparecem no dado;

- Desenvolver habilidades e atitudes sociais;

- Respeitar as regras estabelecidas seguindo e aceitando as consequências na finalização do jogo.

\section{TEMPO/ PERÍODO:}

- Período de desenvolvimento: 2 semanas.

- De 13 a 24 de abril de 2015.

\section{$\checkmark$ PÚBLICO ALVO:}

Infantil III A e B. Crianças de 4/5 anos.

\section{RECURSOS/ MATERIAIS:}


- Tabuleiro;

- Tampinhas de garrafas;

- Dados;

- Máquina fotográfica;

- Cartolina para cartaz.

\section{$\checkmark$ ESTRATÉGIAS/DESENVOLVIMENTO:}

$\checkmark$ Apresenta-se o tabuleiro do jogo da trilha das formas e os dados.

- Vocês conhecem este tabuleiro?

- Para que ele serve?

- O que é preciso para que este jogo aconteça?

- Para que serve o dado?

- Observe o dado, o que veem? Estes pontinhos significam o quê?

- Vocês gostariam de jogar o jogo da trilha das formas?

- As atividades iniciaram pela apresentação do tabuleiro, em seguida reflexão da primeira jogada. Os momentos seguintes se deram após rodas de conversa como: construindo as regras do jogo; jogando com um amigo; registro do jogo por meio de desenho; refletindo e pintando as formas no tabuleiro, completando os números e construindo um tabuleiro.

\section{$\checkmark$ AVALIAÇÃO:}

- Rodas de conversas;

- Registros na apostila;

- Reflexões durante a construção do tabuleiro e nas intervenções dialógicas durante as jogadas.

\section{REFERÊNCIAS:}

Livro Caleidoscópio - 5 anos - RSE.

Referencial Curricular Nacional - Educação Infantil.

ANTUNES, Celso. “As Inteligências Múltiplas e seus estímulos”- Ed. Papirus.

www.Malbatahan.com.br/sobre-artigos.php.

www.Malbatahan.com.br/artigos/artigo-pedropaulo-Salles.pdf. 


\title{
Partilha de Experiência Matemática Interdisciplinar dos $5^{\circ}$ Anos A e B
}

\author{
"Aquele que toma a Realidade e dela faz um sonho é um poeta, um \\ artista. Artista e poeta será também aquele que do sonho faz \\ realidade!" (Malba Tahan)
}

1- TEMA: A literatura abrindo caminhos para o entendimento matemático.

2- PROFESSORAS: Gisele Gama e Cecília Broca.

\section{3- JUSTIFICATIVA:}

A Matemática sempre fora considerada pelos estudantes uma ciência complicada e de difícil entendimento. Partindo dessa óptica, propomos trabalhar a matemática através da literatura.

Neste $1^{\circ}$ trimestre, desenvolvemos o projeto de leitura com o autor Monteiro Lobato e nosso propósito foi justamente unir este autor com Malba Tahan, mostrando e descobrindo com os alunos, suas afinidades.

Pretendemos contribuir no processo de ensino e aprendizagem de forma significativa e acima de tudo, que permita ao aluno ir além, ler além da entrelinhas e debruçar-se diante dos livros e dos cálculos...

\section{4- OBJETIVOS GERAIS:}

- Incentivar os alunos pelo encantamento da literatura e despertar o interesse pela matemática.

- Proporcionar aos alunos a oportunidade para ler, interpretar, brincar, desenvolver e proporcionar a interação da matemática e da literatura com o cotidiano.

\section{5- OBJETIVOS ESPECÍFICOS:}

- Trabalhar a literatura infantil "Emília no País da Gramática" nas rodas de leitura (biblioteca);

- Ler os capítulos I e XI do livro "Aritmética da Emília";

-Levantar os conhecimentos matemáticos relacionados à fração e sistema monetário;

- Resolver situação problema, através da literatura infantil de Monteiro Lobato;

- Criar e construir uma oficina literária através das leituras realizadas na biblioteca. 


\section{6- TEMPO/PERÍODO:}

18 aulas de Língua Portuguesa e Matemática.

\section{7- RECURSOS/ MATERIAIS:}

- Folhas de sulfite;

- Materiais fotocopiados;

- Fantoches;

- E.V.A;

- Cartolinas;

- Lápis e borracha;

- Fantasias;

- Mesa;

- Cestos;

- Guloseimas;

\section{8- ESTRATÉGIAS/DESENVOLVIMENTO:}

a-) Leitura semanalmente de alguns capítulos do livro "Emília no país da Gramática";

b-) Incentivar os alunos a criarem jogos que retratem o conteúdo gramatical no livro para a oficina literária;

c-) Leitura dos capítulos I e XI do livro "A aritmética da Emília";

d-) Trabalho com o texto literário que envolve a literatura e a matemática;

e-) Entendendo a ligação entre Monteiro Lobato e Malba Tahan - seus costumes, criação dos personagens, os livros escritos com o incentivo ao estudo matemático, os lugares que possibilitaram tantas criações para suas histórias (Arábia Saudita e o Sítio do Picapau Amarelo);

f-) Trabalhar diversos gêneros textuais, como instrucionais e biográficos;

g-) Resolução do problema encontrado na literatura de Monteiro Lobato com os alunos (frações e sistema monetário); 
9- REGISTRO FOTOGRÁFICO:
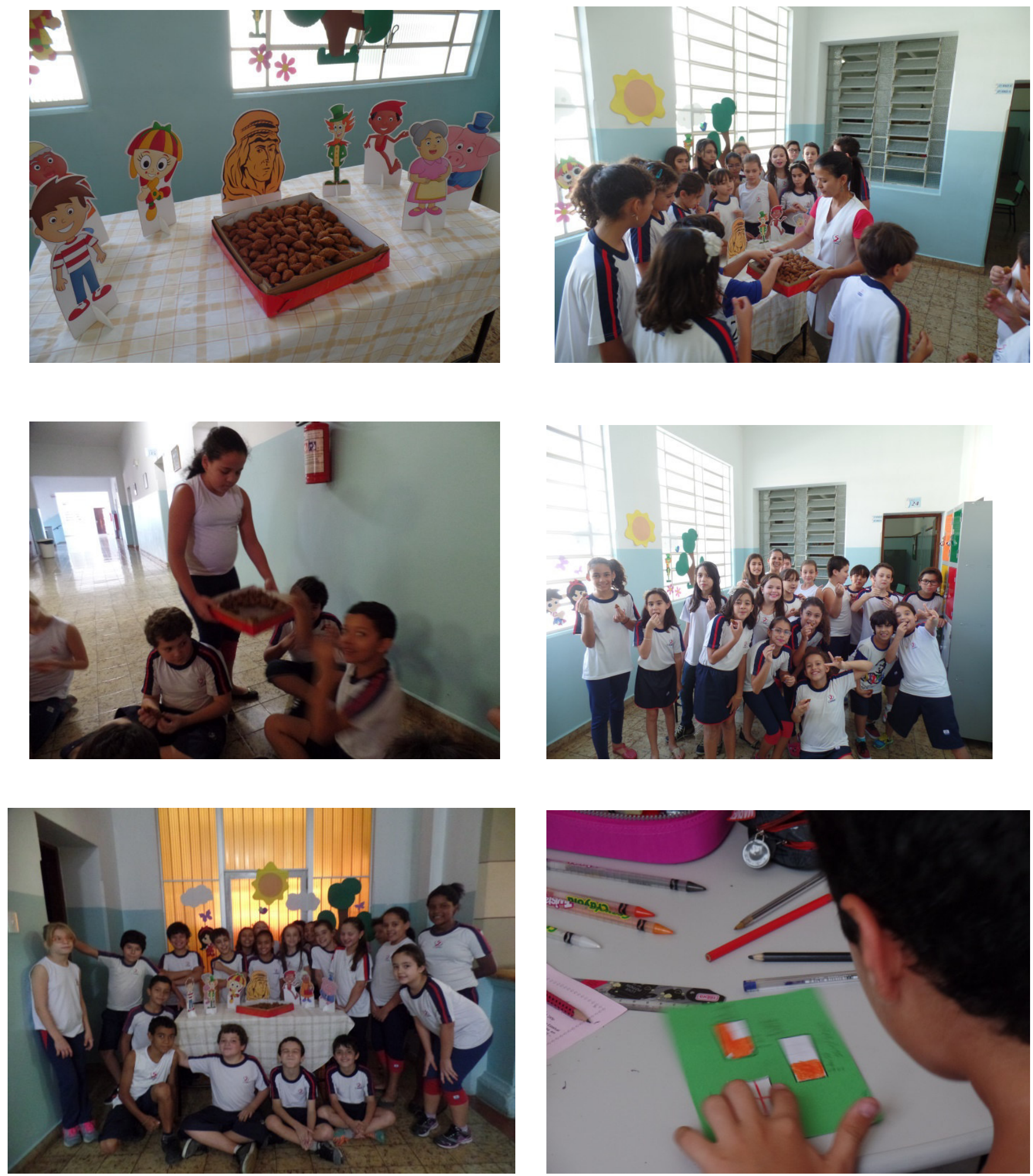

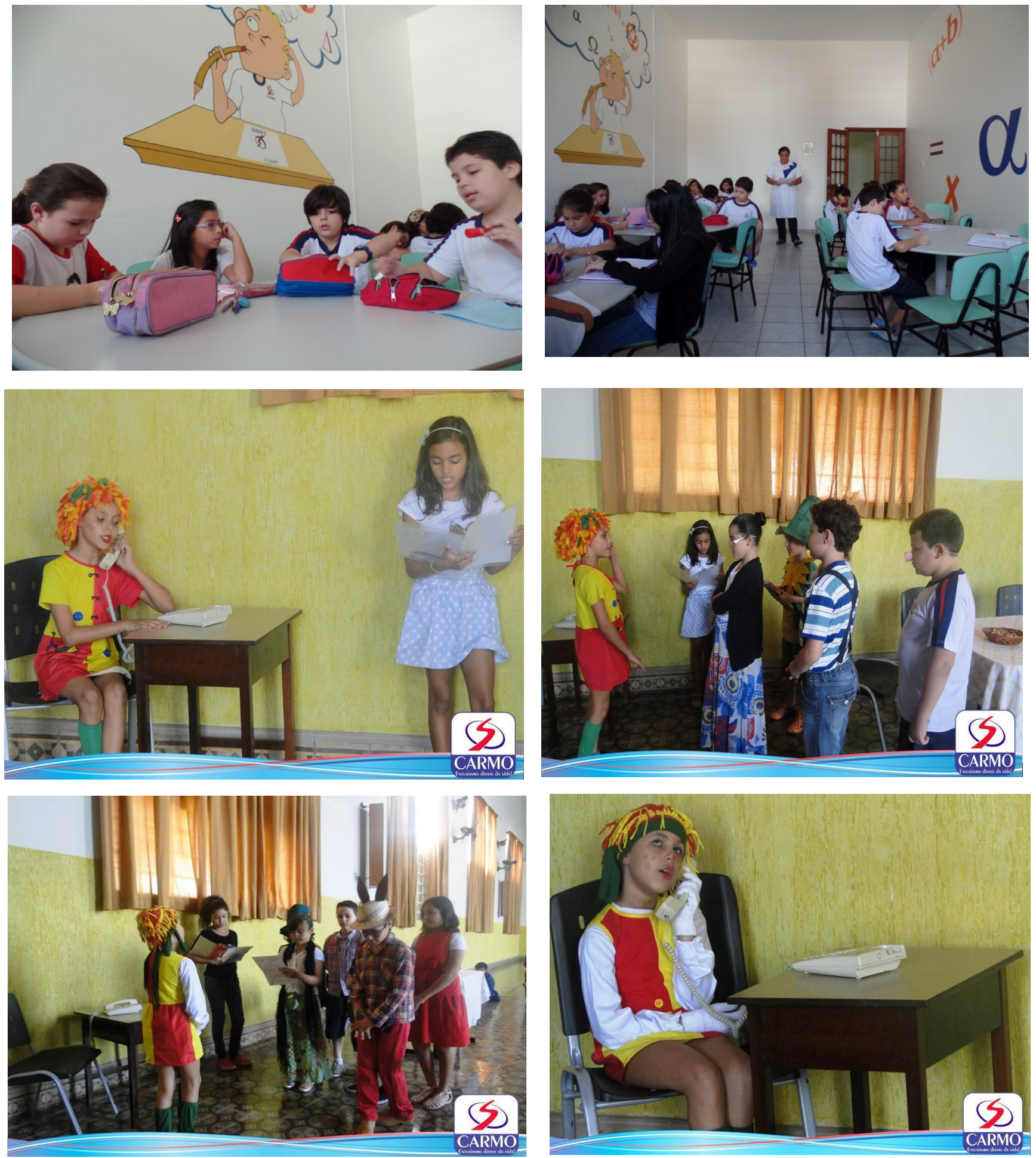

10- AVALIAÇÃO CRÍTICA DA PROPOSTA:

A avaliação aconteceu de forma processual, formativa e diagnóstica, valorizando o que cada aluno sabia e aprofundando constantemente, alcançando grande melhoria no processo ensino-aprendizagem. 


\section{ANEXO S}

Planejamentos para a Exposição Malbatahânica e Reunião de Pais

\section{TURMAS:}

Infantil I A

Infantil I B

TEMA DA PARTILHA DE EXPERIÊNCIA MATEMÁTICA:

Projeto de Leitura Interdisciplinar: "Fofinho".

\begin{tabular}{|c|c|}
\hline Quando? & $\begin{array}{l}\text { Reunião de Pais e Responsáveis. } \\
\begin{array}{l}\text { Dia: } 08 / 06 / 2015 \\
\text { Horário: } 18: 15\end{array}\end{array}$ \\
\hline Onde? & Na sala de aula de cada Professora. \\
\hline $\begin{array}{l}\text { Quais } \\
\text { produtos e/ou } \\
\text { atividades } \\
\quad \text { serão } \\
\text { expostos (as)? } \\
\text { Especifiquem. }\end{array}$ &  \\
\hline $\begin{array}{l}\text { Como serão } \\
\text { expostos? } \\
\text { Expliquem os } \\
\text { detalhes. }\end{array}$ & $\begin{array}{l}\text { Os painéis poderão ser colocados nos varais de atividades e também } \\
\text { na lousa, as pastas deveram ficar nas mesinhas da sala, juntamente } \\
\text { com a sacola de leitura do projeto. } \\
\text { Os materiais pedagógicos ficarão expostos em cantinho previamente } \\
\text { preparado com os temas e objetivos das atividades. }\end{array}$ \\
\hline $\begin{array}{c}\text { Sugestões e } \\
\text { ideias? }\end{array}$ & $\begin{array}{l}\text { Preparar uma oração para iniciar a reunião com os pais; Preparar } \\
\text { previamente a pauta para reunião; escolher um texto reflexivo de } \\
\text { acordo com a realidade da sala (observada por cada professora); } \\
\text { preparar um "agrado" (bala ou bombom) para os pais como } \\
\text { agradecimento da presença e demonstração da importância na } \\
\text { parceria entre escola e família. }\end{array}$ \\
\hline
\end{tabular}


TURMAS:

Infantil I C

Infantil ID

TEMA DA PARTILHA DE EXPERIÊNCIA MATEMÁTICA:

Classificação e seriação de blocos lógicos.

\begin{tabular}{|c|c|}
\hline Quando? & $\begin{array}{l}\text { Reunião de Pais e Responsáveis. } \\
\begin{array}{ll}\text { Dia: } 08 / 06 / 2015 & \text { Horário: } 18: 15\end{array}\end{array}$ \\
\hline Onde? & Na sala de aula de cada Professora. \\
\hline $\begin{array}{l}\text { Quais } \\
\text { produtos e/ou } \\
\text { atividades } \\
\quad \text { serão } \\
\text { expostos (as)? } \\
\text { Especifiquem. }\end{array}$ & $\begin{array}{l}\text { Iremos expor todos os trabalhos que foram realizados ao longo do } \\
\text { semestre. Como: painéis das figuras geométricas, jogos de } \\
\text { classificação das cores, gráficos da escolha do nome do boneco } \\
\text { (interdisciplinar com natureza e sociedade) fotos de todas as } \\
\text { atividades e brincadeiras realizadas, blocos lógicos, alinhavo das } \\
\text { formas, etc. Também estarão expostos os materiais do projeto de } \\
\text { leitura, interdisciplinar com o conteúdo de matemática, contendo, } \\
\text { boliche do Elmer, atividades em folha A3 que foram realizadas com } \\
\text { tintas e papéis picados, cartazes, tabuleiro do bingo, livro da história } \\
\text { trabalhada e o elefante xadrez (urso). }\end{array}$ \\
\hline $\begin{array}{l}\text { Como serão } \\
\text { expostos? } \\
\text { Expliquem os } \\
\text { detalhes. }\end{array}$ & $\begin{array}{l}\text { Dividiremos a sala em três partes para a apresentação das atividades. } \\
\text { Colocaremos alguns materiais nos varais da sala e também usaremos } \\
\text { a lousa para a apresentação das fotos. No chão usaremos um tecido } \\
\text { (T.N.T) e em cima dele a caixa de apresentação do projeto de leitura, } \\
\text { ao lado o livro, o elefante xadrez, o boliche junto da bolinha que as } \\
\text { crianças brincaram e os tabuleiros do bingo. }\end{array}$ \\
\hline $\begin{array}{c}\text { Sugestões e } \\
\text { ideias? }\end{array}$ & $\begin{array}{l}\text { A porta de cada sala poderia ter uma decoração de acordo com o } \\
\text { projeto de cada dupla. Seria uma maneira de proporcionar a } \\
\text { curiosidade dos pais desde a entrada. Além do que, todos que } \\
\text { passassem para as reuniões iriam observar os diferentes trabalhos } \\
\text { que foram realizados ao longo do semestre desde o Infantil I até o } \\
\text { Infantil III. }\end{array}$ \\
\hline
\end{tabular}


TURMAS:

Infantil II A

Infantil II B

TEMA DA PARTILHA DE EXPERIÊNCIA MATEMÁTICA:

Interdisciplinaridade Matemática - Caleidoscópio e Projeto de Leitura.

\begin{tabular}{|c|c|}
\hline Quando? & $\begin{array}{l}\text { Reunião de Pais e Responsáveis. } \\
\begin{array}{ll}\text { Dia: } 09 / 06 / 2015 & \text { Horário: } 18: 15\end{array}\end{array}$ \\
\hline Onde? & Na sala de aula de cada Professora. \\
\hline $\begin{array}{l}\text { Quais } \\
\text { produtos e/ou } \\
\text { atividades } \\
\quad \text { serão } \\
\text { expostos (as)? } \\
\text { Especifiquem. }\end{array}$ & $\begin{array}{l}\text { - Pasta com trabalhos realizados em casa (tarefa) e em sala de aula, } \\
\text { referentes ao Projeto de Leitura. } \\
\text { - Arca feita de caixa de sapato e animais em papel, atividade } \\
\text { realizada em sala. } \\
\text { - Painel em folha A3, com colagens referentes à Arca de Noé. } \\
\text {-Pequeno painel de fotos dos momentos da motivação do projeto e } \\
\text { algumas atividades. }\end{array}$ \\
\hline $\begin{array}{l}\text { Como serão } \\
\text { expostos? } \\
\text { Expliquem os } \\
\text { detalhes. }\end{array}$ & $\begin{array}{l}\text { - A atividade do painel será exposta no varal da sala, para que todas } \\
\text { fiquem visíveis. } \\
\text { - As arcas de caixa de papel ficarão no chão da sala, perto do } \\
\text { cantinho das mochilas, em cima de um TNT azul, na frente de cada } \\
\text { arca a pasta com as atividades. } \\
\text { - O painel com as fotos será colocado na lousa, para que todos } \\
\text { possam apreciar. }\end{array}$ \\
\hline $\begin{array}{c}\text { Sugestões e } \\
\text { ideias? }\end{array}$ & \\
\hline
\end{tabular}


TURMAS:

Infantil III A

Infantil III B

TEMA DA PARTILHA DE EXPERIÊNCIA MATEMÁTICA:

TRILHA DAS FORMAS

\begin{tabular}{|c|c|}
\hline Quando? & $\begin{array}{l}\text { Reunião de Pais e Responsáveis. } \\
\begin{array}{ll}\text { Dia: } 09 / 06 / 2015 & \text { Horário: } 18: 15\end{array}\end{array}$ \\
\hline Onde? & $\begin{array}{l}\text { Na sala de aula de cada Professora. } \\
\text { Elza Sala } 9 \text { e Eliane Sala } 10\end{array}$ \\
\hline $\begin{array}{l}\text { Quais } \\
\text { produtos e/ou } \\
\text { atividades } \\
\quad \text { serão } \\
\text { expostos (as)? } \\
\text { Especifiquem. }\end{array}$ & $\begin{array}{l}\text { - Fotografias da realização das atividades durante a aplicação } \\
\text { do projeto de matemática e de leitura: } \\
\text { - Cartazes construídos pelos alunos, contendo as regras do jogo } \\
\text { e o tabuleiro; } \\
\text { - Objetos construídos com argila e outros materiais sobre a } \\
\text { cultura indígena. }\end{array}$ \\
\hline $\begin{array}{l}\text { Como serão } \\
\text { expostos? } \\
\text { Expliquem os } \\
\text { detalhes. }\end{array}$ & $\begin{array}{l}\text { Painel Móvel e varal contendo fotografias das atividades propostas } \\
\text { durante a realização do projeto de matemática e projeto de leitura; } \\
\text { mesa contendo tabuleiro do jogo da Trilha das formas, os objetos da } \\
\text { cultura indígena, construídos e confeccionados pelos próprios alunos. }\end{array}$ \\
\hline $\begin{array}{l}\text { Sugestões e } \\
\text { ideias? }\end{array}$ & $\begin{array}{l}\text { Como geralmente nas reuniões fazemos dinâmicas com os pais, neste } \\
\text { dia a dinâmica será a proposta do jogo da Trilha das Formas. Assim, } \\
\text { podendo oferecer aos pais após a realização da proposta, o } \\
\text { entendimento de que o jogo de tabuleiro é um meio de desenvolver } \\
\text { habilidades: como observação, análise, levantamento de hipóteses, } \\
\text { busca de suposições, reflexão, tomada de decisão, argumentação e } \\
\text { organização que estão estreitamente relacionados ao raciocínio } \\
\text { lógico-matemático. }\end{array}$ \\
\hline
\end{tabular}


TURMAS:

$1^{\circ}$ Ano A

$1^{\circ}$ Ano B

TEMA DA PARTILHA DE EXPERIÊNCIA MATEMÁTICA:

A Matemática de Malba Tahan e a Matemática da Rede Salesiana de Escolas

\begin{tabular}{|c|l|}
\hline Quando? & Reunião de Pais e Responsáveis. \\
\hline Onde? & Na: 27/05/2015 Hala de aula de cada Professora. \\
\hline $\begin{array}{c}\text { Quais } \\
\text { produtos e/ou } \\
\text { atividades } \\
\text { serão } \\
\text { expostos (as)? } \\
\text { Especifiquem. }\end{array}$ & $\begin{array}{l}\text { Iremos expor fotos de diversos momentos em que foram trabalhados os } \\
\text { amarelinha, bingo de números, etc. }\end{array}$ \\
\hline $\begin{array}{c}\text { Como serão } \\
\text { expostos? } \\
\text { Expliquem os } \\
\text { detalhes. }\end{array}$ & $\begin{array}{l}\text { Gostaríamos de expor as fotos no tablado (precisaremos de dois, um } \\
\text { para cada sala) e os jogos num cantinho preparado no fundo da sala. }\end{array}$ \\
& \\
\hline $\begin{array}{c}\text { Sugestões e } \\
\text { ideias? }\end{array}$ & \\
\hline
\end{tabular}


TURMAS:

$2^{\circ}$ Ano A

$2^{\circ}$ Ano B

TEMA DA PARTILHA DE EXPERIÊNCIA MATEMÁTICA:

Trabalhando com a Adição

\begin{tabular}{|c|c|}
\hline Quando? & $\begin{array}{l}\text { Reunião de Pais e Responsáveis. } \\
\begin{array}{l}\text { Dia: } 27 / 05 / 2015 \quad \text { Horário: } 18: 15\end{array}\end{array}$ \\
\hline Onde? & Na sala de aula de cada Professora. \\
\hline $\begin{array}{c}\text { Quais } \\
\text { produtos e/ou } \\
\text { atividades } \\
\text { serão } \\
\text { expostos (as)? } \\
\text { Especifiquem. }\end{array}$ & $\begin{array}{l}\text { Serão expostas as fotos dos alunos, realizando diversas atividades } \\
\text { concretas } e \text { brincadeiras que contemplam os eixos trabalhados no } \\
\text { livro da RSE. }\end{array}$ \\
\hline $\begin{array}{l}\text { Como serão } \\
\text { expostos? } \\
\text { Expliquem os } \\
\text { detalhes. }\end{array}$ & $\begin{array}{l}\text { Será exposto um painel com fotos dos alunos com o título de cada } \\
\text { atividade realizado e o objetivo. }\end{array}$ \\
\hline $\begin{array}{l}\text { Sugestões e } \\
\text { ideias? }\end{array}$ & $\begin{array}{l}\text { Relatar aos pais que essas atividades que foram realizadas no } \\
\text { concreto tiveram o início desde a primeira fase no infantil e que as } \\
\text { atividades são progressivas, onde cada professora relata o seu } \\
\text { caminhar ao grupo. Colocar uma foto na entrada da escada de cada } \\
\text { grupo que apresentou. }\end{array}$ \\
\hline
\end{tabular}


TURMAS:

$3^{\circ}$ ano $\mathrm{A}$

$3^{\circ}$ ano B

TEMA DA PARTILHA DE EXPERIÊNCIA MATEMÁTICA:

Observando e criando sob os diferentes pontos de vista dos sólidos geométricas.

\begin{tabular}{|c|c|}
\hline Quando? & $\begin{array}{l}\text { Reunião de Pais e Responsáveis. } \\
\begin{array}{l}\text { Dia: } 28 / 05 / 2015 \\
\text { Horário: } 18: 15\end{array}\end{array}$ \\
\hline Onde? & Na sala de aula de cada Professora. \\
\hline $\begin{array}{l}\text { Quais } \\
\text { produtos e/ou } \\
\text { atividades } \\
\quad \text { serão } \\
\text { expostos (as)? } \\
\text { Especifiquem. }\end{array}$ & $\begin{array}{l}\text { - Mesa com as embalagens; } \\
\text { - Fotos (pirâmide de massinha e construção da atividade com as } \\
\text { embalagens); } \\
\text { - Móbiles de pirâmide; } \\
\text { - Pirâmide de base quadrada feita com massinha e palitos. }\end{array}$ \\
\hline $\begin{array}{l}\text { Como serão } \\
\text { expostos? } \\
\text { Expliquem os } \\
\text { detalhes. }\end{array}$ & $\begin{array}{l}\text { - Varal as sala (móbiles); } \\
\text { - Lousa (no centro escrito o tema e uma frase de Malba Tahan) } \\
\text { e ao redor as fotos dos alunos; } \\
\text { - No fundo ou lateral a mesa com as embalagens. Nas mesas, os } \\
\text { livrinhos para fazerem as atividades; } \\
\text { - Mesa no fundo da sala com as pirâmides de base quadrada. }\end{array}$ \\
\hline $\begin{array}{c}\text { Sugestões e } \\
\text { ideias? }\end{array}$ & $\begin{array}{l}\text { - Que as atividades fossem expostas no pórtico fazendo uma } \\
\text { interação desde a Educação Infantil até ao } 5^{\circ} \text { ano E.F.I. }\end{array}$ \\
\hline
\end{tabular}


TURMAS:

$4^{\circ}$ Ano A

$4^{\circ}$ Ano B

TEMA DA PARTILHA DE EXPERIÊNCIA MATEMÁTICA:

Trabalhando com Grandezas e Medidas.

\begin{tabular}{|c|c|}
\hline Quando? & $\begin{array}{l}\text { Reunião de Pais e Responsáveis. } \\
\begin{array}{l}\text { Dia: } 28 / 05 / 2015 \quad \text { Horário: } 18: 15\end{array}\end{array}$ \\
\hline Onde? & Na sala de aula de cada Professora. \\
\hline $\begin{array}{c}\text { Quais } \\
\text { produtos e/ou } \\
\text { atividades } \\
\text { serão } \\
\text { expostos (as)? } \\
\text { Especifiquem. }\end{array}$ & $\begin{array}{l}\text { - Apresentação de um vídeo do desenvolvimento do trabalho. } \\
\text { - Apresentação das atividades dos alunos em sala de aula. }\end{array}$ \\
\hline $\begin{array}{l}\text { Como serão } \\
\text { expostos? } \\
\text { Expliquem os } \\
\text { detalhes. }\end{array}$ & $\begin{array}{l}\text { O trabalho será descrito e ilustrado por meio de registros fotográficos } \\
\text { e os pais participarão da mesma oficina realizada com os alunos em } \\
\text { sala de aula, a partir da sequência didática do livro paradidático "Os } \\
\text { irmãos gêmeos", da autora Young So Yoo. }\end{array}$ \\
\hline $\begin{array}{l}\text { Sugestões e } \\
\text { ideias? }\end{array}$ & \\
\hline
\end{tabular}


TURMAS:

$5^{\text {os }}$ anos A e B

\section{TEMA DA PARTILHA DE EXPERIÊNCIA MATEMÁTICA:}

A literatura abrindo caminhos para o entendimento matemático.

\begin{tabular}{|c|c|}
\hline Quando? & $\begin{array}{l}\text { Reunião de Pais e Responsáveis. } \\
\begin{array}{ll}\text { Dia: } 28 / 05 / 2015 & \text { Horário: } 18: 15\end{array}\end{array}$ \\
\hline Onde? & Na sala de aula de cada Professora. \\
\hline $\begin{array}{l}\text { Quais } \\
\text { produtos e/ou } \\
\text { atividades } \\
\quad \text { serão } \\
\text { expostos (as)? } \\
\text { Especifiquem. }\end{array}$ & $\begin{array}{l}\text { - Painel de EVA com imagens do livro "Emília no País da } \\
\text { Gramática"; } \\
\text { - Baú com fantasias utilizadas no teatro dramático; } \\
\text { - Livrinho com a biografia, verbetes, receitas e personagens de Malba } \\
\text { Tahan e Monteiro Lobato; } \\
\text { - Fotos das atividades desenvolvidas em sala; } \\
\text { - Material de matemática sobre fraçães; } \\
\text { - Livros de literatura infantil - "Emília no País da Gramática"; } \\
\text { - Apresentação de um vídeo do desenvolvimento do trabalho. }\end{array}$ \\
\hline $\begin{array}{l}\text { Como serão } \\
\text { expostos? } \\
\text { Expliquem os } \\
\text { detalhes. }\end{array}$ & $\begin{array}{l}\text { - Arrumar com lycra o painel com as imagens do livro; } \\
\text { - Organizar as fotos entre as imagens do painel; } \\
\text { Em uma mesa com lycra, expor os livros de literatura do } 1^{\circ} \text { trimestre, } \\
\text { os livrinhos (Malba Tahan e Monteiro Lobato) e as atividades de } \\
\text { matemática; } \\
\text { - Colocar em um canto o baú com as fantasias utilizadas no texto } \\
\text { dramático da Turma do Sítio do Picapau Amarelo. }\end{array}$ \\
\hline $\begin{array}{c}\text { Sugestões e } \\
\text { ideias? }\end{array}$ & $\begin{array}{l}\text { - A nossa sugestão é que esta exposição ocorresse no pórtico unindo } \\
\text { todas as turmas do Colégio, possivelmente teria uma maior } \\
\text { visibilidade. }\end{array}$ \\
\hline
\end{tabular}

\section{ATIVIDADE A SER PARTILHADA:}

TEMA: Usando o círculo para trabalhar diferentes conteúdos

OBJETIVO: Oferecer elementos para compreender os processos necessários para o desenvolvimento do raciocínio lógico. 
ATIVIDADE PRÁTICA: Entregar aos pais um círculo de $4 \mathrm{~cm}$ de raio. Pedir que dobre em 4 partes iguais.

\section{CONTEÚDOS A SEREM TRABALHADOS:}

- Frações;

- Porcentagem;

- Ângulos;

- Horas e minutos;

- Questionar medidas de massa, capacidade e comprimento.

- Sistema Monetário.

\section{QUESTÕES A SEREM LEVANTADAS:}

1- O que é o raio de uma circunferência?

2- O que é diâmetro de uma circunferência?

3- Qual é a relação entre o raio e o diâmetro?

4- 1/4 de hora, quantos minutos são?

5- 2/4 do círculo é o mesmo que 50\%. Por quê?

6- 3/4 de giro, quantos graus são?

7- É verdadeiro afirmar que $250 \mathrm{~g}$ são $1 / 4$ do $\mathrm{Kg}$ ? 
Coletânea de "Poemas Malbatahânicos"

\section{INSTITUTO NOSSA SENHORA DO CARMO}

\section{POEMAS}

\section{MALBATAHÂNICOS}
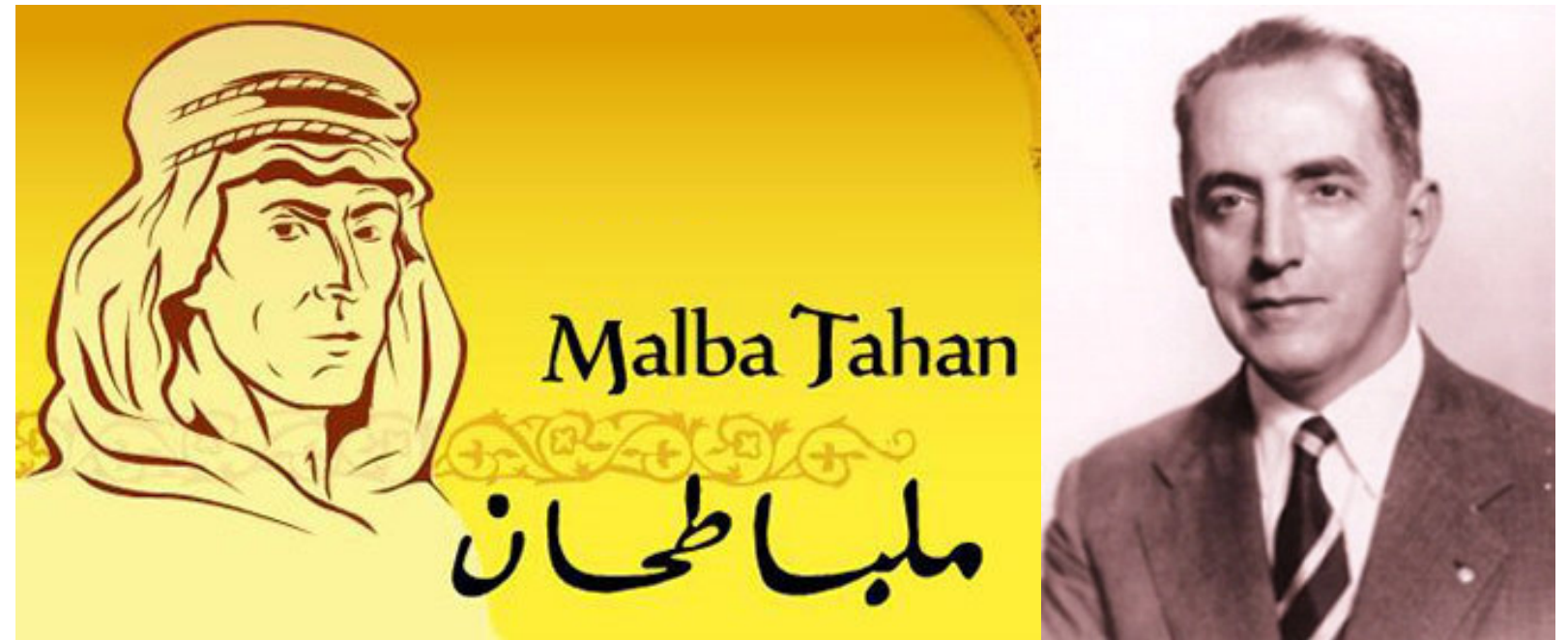
“A matemática, senhora que ensina o homem a ser simples e modesto, é a base de todas as ciências e de todas as artes."

(Malba Tahan)

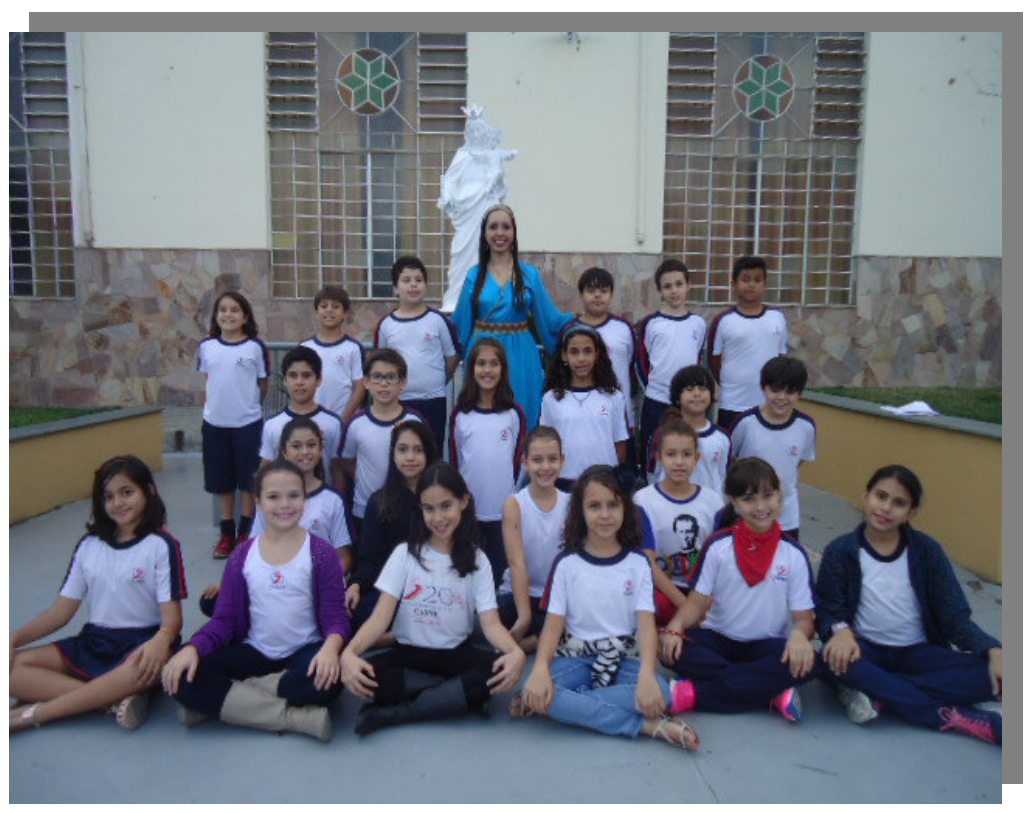

Turma 1: $5^{\circ}$ Ano

“Há uma única ciência, a matemática,

a qual ninguém se pode jactar de conhecer

porque suas conquistas são, por natureza, infinitas.

Dela toda gente fala, sobretudo os que mais a ignoram.”

(Malba Tahan)

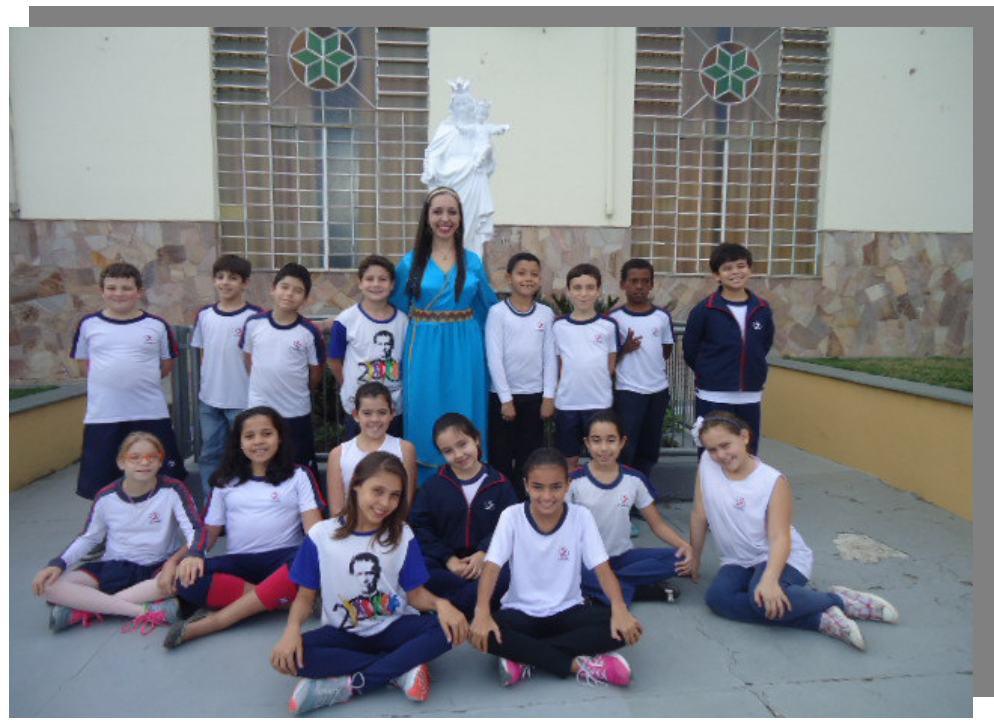

Turma 2: $5^{\circ}$ Ano 
Dedicamos este caderno de poemas à Inspetora Irmã Helena Gesser, com carinho. 


\section{APRESENTAÇÃO}

O eixo central deste trabalho foi aplicar a prática educativa de Júlio César de Mello e Souza, pseudônimo Malba Tahan Malba Tahan, e a interdisciplinaridade como um possível caminho para superar as dificuldades do ensino de Matemática no $5^{\circ}$ ano do Ensino Fundamental I do Instituto Nossa Senhora do Carmo (Rede Salesiana de Escolas), localizado na cidade de Guaratinguetá-SP.

O Projeto de Pesquisa foi desenvolvido com base no estudo sobre a interdisciplinaridade como necessidade de superar a visão fragmentada da produção de conhecimento e sua construção coletiva a partir de grupos interativos, que favorecem o aprendizado dialógico, produzido por meio da interação. Tendo como referência a metodologia comunicativo-crítica, este trabalho contou com observações comunicativas; relatos dos participantes e grupos de discussão como seus principais instrumentos de coleta de dados; envolveu uma análise intersubjetiva dos dados, em parceria com os (as) Professores (as) da Educação Infantil ao Ensino Fundamental I e estudantes das turmas dos $5^{\text {os }}$ Anos do Ensino Fundamental I.

Resgatando o legado literário e pedagógico de Júlio César de Mello e Souza Malba Tahan, observou-se que as concepções malbatahânicas estabeleceram uma mobilização interdisciplinar, no intuito de pensar, elaborar e decidir quais propostas e intervenções foram aplicadas a partir de um trabalho interativo e dialógico da Matemática com a Literatura, assim como destas com outras áreas do saber, na parceria criada com os agentes educativos.

Estes "Poemas Malbatahânicos" foram escritos pelos estudantes dos $5^{\text {os }}$ Anos após o desenvolvimento das etapas do Projeto de Pesquisa. 
MALBA TAHAN

Eu estou gostando de saber que

Malba Tahan era um aluno muito

Ruim de Matemática, mas que um dia

Virou um professor de Matemática.

Ele adorava contar sapos e colecionar

Até que um dia ele fez um poema

Sobre sapos ele contava e contava

A quantidade de sapos que ele via.

Eu estou gostando muito do Projeto

Da Tia Meily, além de eu estar Aprendendo muito de Malba Tahan

A gente faz brincadeiras tipo um teatro.

Autor: Estudante 1

Equipe: "Os Matemáticos 1" $5^{\circ}$ Ano A
MALBA TAHAN

Eu gostei muito de Malba Tahan e seus livros

Soube que tinha muitas dificuldades em Matemática Soube que Malba Tahan fez parceria com Monteiro Lobato

Também fez muitos livros

O melhor e mais vendido Foi "O homem que calculava".

Autor: Estudante 2 Equipe: "Adição" "Adição"

B

\section{Malba Tahan era um homem generoso}

Que gostava de ensinar crianças Por meio de textos e desenhos.

Malba Tahan não gostava de Matemática

Mas com dedicação e esforço começou a gostar

$\mathrm{E}$ isso passou a nos inspirar.

Foi legal a gente conhecer sobre Malba Tahan

Foi também divertido escolher o nome do grupo

E muito legal aprender os textos dele.

Autor: Estudante 3 Equipe: "Os Matemáticos 1" $5^{\circ}$ Ano A

\section{MALBA TAHAN}

Eu achei muito legal

Pois aquela vez que a sala foi nas salas e apresentou

Aquilo foi irado! É a vida...

Agora eu não tenho mais vergonha

Eu gostei de tudo:

Equipe, os trabalhos..

Foi legal, foi legal!

Foi demais!

Autor: Estudante 4

Equipe: "Os Matemáticos 3" $5^{\circ}$ Ano A
HISTÓRIAS SOBRE MALBA TAHAN

Histórias: curiosas, engraçadas Divertidas, interessantíssimas, Pequenas e grandes Tudo sobre Matemática e Português.

Histórias como: o livro do destino,

Os dois cântaros,

O fio da aranho,

O homem que calculava e os 35 camelos...

As histórias de Malba Tahan São muito conhecidas pelo mundo Aprendemos muito com elas Em nossos Laboratórios.

Autor: Estudante 5 Equipe: "Os Divisores" $5^{\circ}$ Ano A
ORGANIZAÇÃO DOS NÚMEROS

No início parecia ser tudo complicado

Quando olhava os números e letras

Estavam embaralhados.

Que dificuldade, não sabia como começar

E também não sabia terminar O tempo foi passando e tudo foi se organizando.

A Professora me ensinou a tudo organizar

Com as letras e os números Os problemas vou solucionar.

Autor: Estudante 6 Equipe: "Os Matemáticos 2" $5^{\circ}$ Ano 
LITERATURA COM MALBA TAHAN

Ler ou não ler?

Eis a questão!

Ler é entrar em uma aventura,

Ler com imaginação.

Com Malba Tahan

Tudo fica melhor.

Aprendendo a Matemática e a

Língua Portuguesa,

Um livro é uma riqueza!

Malba Tahan

Ensinava a Matemática

Com a ajuda da literatura,

Um pensamento ruim, o livro cura!

Autor: Estudante 7

Equipe: "Os Matemáticos 1" $5^{\circ}$ Ano A
UM POUCO SOBRE MALBA TAHAN

Malba Tahan

Era um grande colecionador de sapos Mas era de mentira.

Era péssimo em Matemática Com a ajuda de seu Professor

Tornou-se um ótimo Professor de Matemática.

Era um ótimo contador de histórias

Escrevia diversos contos E fábulas infantis.

Amava a literatura E os livros de Matemática.

Autor: Estudante 8

Equipe: "Os Matemáticos 3" $5^{\circ}$ Ano A

\section{MALBA TAHAN}

Nós aprendemos várias coisas Sobre Malba Tahan

E Monteiro Lobato.

Mais coisas de Malba Tahan

Que misturava Português com a

Matemática

E dava certo!

Escrevia livros

Colecionava sapos

E tinha o homem que calculava.

Autor: Estudante 9

Equipe: "Os Matemáticos 3" $5^{\circ}$ Ano A

\section{A LITERATURA TAHÂNICA}

Um homem que escrevia literatura

Que hoje virou cultura

Um homem promissor

Que virou escritor.

Seu objetivo era juntar

Para todos se lembrar

Foram aulas diferentes

Que me deixaram contente!

Autor: Estudante 10

Equipe: "Os Matemáticos 2" $5^{\circ}$ Ano A

\section{PORTUGUÊS E MATEMÁTICA}

Português não rima com Matemática Mas aprendi os dois juntos

$E$ vi que tem tudo a ver.

Descobri que mesmo que não goste

Você vai usar em tudo e toda hora.

A Coordenadora Meily fez com que

Aprendêssemos a Matemática e o Português

De um jeito muito mais divertido

$\mathrm{E}$ isso nos inspira para fazer uma coisa bonita

Mesmo não gostando da matéria

Mas sabendo que é importante E muito interessante!

Autor: Estudante 11

Equipe: "Os Matemáticos 3" $5^{\circ}$ Ano A

\section{MALBA TAHAN}

Malba Tahan foi um Professor de mão cheia

Sempre gostou de ensinar seus alunos

Pela literatura Matemática.

Malba Tahan construía primeiro o livro

E o mais vendido foi "O homem que calculava".

Malba Tahan adorava colecionar sapos

E amava a Arábia.

Malba Tahan nunca foi bom de Matemática

Mas foi um dos maiores divulgadores desta matéria.

Malba Tahan com sua genialidade

Criou um estilo próprio onde a Matemática

E a Literatura andam juntas.

Despertando sempre a atenção dos alunos

Com suas histórias, ficando imortalizado

Por tal maneira de escrever. Autor: Estudante 12

Equipe: "Os Matemáticos 1" $5^{\circ}$ Ano A 


\section{MALBA TAHAN}

Eu aprendi que o Malba Tahan Foi um grande escritor

E ele escreveu vários livros Que ficaram famosos.

A obra mais famosa é "O homem que calculava" Mas a que eu mais gostei Foi “A pequenina luz azul”.

Quando lemos suas obras

É impressionante...

Parece que estamos lá

Viramos um dos seus personagens!

Obrigada, Tia Meily

Por nos apresentar Malba Tahan!

Autor: Estudante 13

Equipe: "Os Matemáticos 2" $5^{\circ}$ ano $A$

\section{MALBA TAHAN}

Com Malba Tahan aprendi que A literatura e a Matemática andam juntas

Quando ouvimos uma história E tentamos resolver o problema de Matemática é legal.

Assim Malba Tahan fazia

Dava aula, contava várias histórias Através delas sempre havia um problema de Matemática

Assim é mais fácil e mais legal de aprender.

Malba Tahan quando criança não gostava de Matemática

Então aprendeu a Matemática pela literatura

Também gostava de colecionar sapos

E quando cresceu virou amigo de Monteiro Lobato.

\section{"SOBRE MALBA TAHAN"}

Malba Tahan

Era muito legal

Adorava sapos

Mas eram de mentira.

Não era bom em Matemática

Seu Professor lhe ajudou

Com essa ajuda se tornou Professor

Amava seu trabalho.

Era um ótimo contador de histórias

Escrevia muitos contos

E fábulas infantis

Amava literatura.

Autor: Estudante 15

Equipe: "Os Divisores" $5^{\circ}$ Ano A

Autor: Estudante 14

Equipe: "Os Divisores"

$5^{\circ}$ ano $A$

\section{A LITERATURA DE MALBA TAHAN}

Gosto de aprender com Malba Tahan Pois aprendo várias lições gramaticais e matemáticas

Gosto de aprender com Malba Tahan

Pois ele nos ensina através de histórias.

Adorei estar presente nos laboratórios Matemática e Língua Portuguesa Pois cada um deles me apresentou Conhecimentos sobre Malba Tahan Adoro Malba Tahan!

Autor: Estudante 16 Equipe: "Os Matemáticos 3" $5^{\circ}$ Ano A

\section{MALBA TAHAN}

Malba Tahan amava Matemática, Mas antes nem gostava

Porque tinha sapos De estimação

Então tempos passaram.

Malba Tahan antes Era colecionador de sapos Hoje, "O homem que calculava".

Autor: Estudante 17

Equipe: "Os Multiplicadores" $5^{\circ}$ Ano A
APRENDENDO COM MALBA TAHAN

Malba Tahan nem sempre

Gostou de Matemática...

Seu Professor lhe incentivou Então ele aprendeu.

Aprendeu a calcular a Matemática

$$
\text { E a nos ensinar }
$$

Aprendi Literatura

Aprendi a Matemática.

Seu sapo, sempre teve consigo Seus 120 anos, sempre estiveram em sua história

Sempre aprendendo

Com Malba Tahan e suas histórias.

Autor: Estudante 18

Equipe: "Os Matemáticos 2" $5^{\circ}$ Ano A 
O MALBA TAHAN

Malba Tahan não era inteligente Colecionava sapos Quando criança.

Adulto foi Professor Colecionava sapos de mentira Ficou muito inteligente.

Gostei muito do Projeto E quando crescer quero ser Professora

Agradeço a todas as minhas Professoras!

Autor: Estudante 19 Equipe: "Os Multiplicadores" $5^{\circ}$ Ano A
MALBA TAHAN

Malba Tahan a Matemática completou

Com sua sabedoria e esperteza No início não foi com a Matemática

Mas com ajuda, todos entram nessa aventura, De dividir, somar Multiplicar e medir Tamanhos e alturas

Hoje entramos nessa aventura Sem pensar, pois a Matemática Está em todo lugar.

Em uma placa de trânsito

Por isso, amamos a Matemática.

Autor: Estudante 20

Equipe: "Os Multiplicadores" $5^{\circ}$ Ano A

\section{MALBA TAHAN}

Malba Tahan foi um homem muito sábio

Ele não gostava de Matemática Quando era criança Começou a gostar quando o Professor o ajudou.

Depois disso ele começou a escrever histórias

De Matemática, Geometria e alguns contos

Como "O homem que calculava", "Os 35 camelos" e vários outros

E o mundo inteiro conheceu suas histórias.

Autor: Estunte 21

Equipe: "Os Matemáticos 1" $5^{\circ}$ Ano A

\section{MALBA TAHAN E NOSSAS ATIVIDADES}

Neste período nós aprendemos várias coisas

Fizemos apresentações nas classes Tivemos aulas na biblioteca e sala de Matemática

Entre diversas coisas.

Aprendemos sobre Malba Tahan Como ele aprende a Matemática Ele também foi o criador do livro

"O homem que calculava"

Gostava de contar histórias.

Aprendi muitas coisas

Adorei esse trabalho sobre Malba Tahan

Conheci como Malba ensinava Matemática

E como a Matemática é tudo!

Autor: Estudante 22

Equipe: "Os Multiplicadores"

\section{MALBA TAHAN}

Júlio César com o nome artístico Malba Tahan

Quem acha que quando criança gostava de Matemática Está enganado Adorava sapos.

Muitos livros durante a vida inteira

O mais famoso foi "O homem que calculava"

Em homenagem a Malba Tahan

Em 6 de maio foi declarado o dia da Matemática.

Autora: Estudante 23

Equipe: "Os Sábios da Matemática” $5^{\circ}$ Ano $B$

\section{COISAS QUE APRENDI SOBRE MALBA TAHAN}

Malba Tahan era um menino Que não sabia tanta Matemática

E quando cresceu era tipo o rei da Matemática

Achei impressionante isso!

Gostei também

Que Malba Tahan era muito amigo

De Monteiro Lobato

Que era um escritor.

Autora: Estudante 24.

Equipe: "Os Sábios da Matemática” $5^{\circ}$ Ano B 


\section{O QUE APRENDI SOBRE MALBA TAHAN}

Gostei de aprender sobre Malba Tahan

Porque ele gostava de Matemática E gostava muito de estudar E gostei dos livros que ele fez.

As aulas que tivemos foram legais Que aprendíamos coisas novas

E brincadeiras muito legais

Achei interessante aprender sobre ele.

Espero que nossa apresentação seja legal

Levarei seus ensinamentos para o resto da vida

Obrigado, Malba Tahan!

Autor: Estudante 25 Equipe: "As fórmulas" $5^{\circ}$ Ano B

\section{TUDO QUE APRENDEMOS}

Gostei muito de Malba Tahan Pois traz muita diversão Principalmente emoção.

Adorei as atividades

Todas com muita criatividade Nos trazendo felicidade.

De portas abertas

Fazemos grandes descobertas

Aprendendo e crescendo.

Autor: Estudante 26

Equipe: "Divisão"

$5^{\circ}$ Ano B

\section{MALBA TAHAN}

Malba Tahan foi grande escritor

Grande amigo de Monteiro Lobato

Com gosto duvidoso

Gostava de sapos.

$\mathrm{Na}$ escola

Não era bom em Matemática

Mas acabou escrevendo sobre ela

E sobre Português também.

Autor: Estudante 27

Equipe:"Divisão"

$5^{\circ}$ Ano B

\section{MALBA TAHAN}

Malba Tahan, o sábio da Matemática

Uma pessoa muito simpática

Gostava muito de ler

E também de aprender

Gostava de ensinar

E de Matemática muito falar.

Gostava de Monteiro Lobato

Eram amigos, de fato.

Autor: Estudante 28 Equipe: "As fórmulas" $5^{\circ}$ Ano B
MALBA

Aprendi sobre a vida de Malba Tahan.

Ele foi um grande Professor de Matemática

Ele não era bom aluno.

E também aprendi

O livro dele Maktub

Uma história

"O nariz do rei Mahendra".

Autor: Estudante 29

Equipe: "Os Sábios da

Matemática”

$5^{\circ}$ Ano $B$
LITERATURA DE MALBA

TAHAN

O projeto que me deu asas para voar

O projeto que me leva à imaginação

O projeto que se aprende brincando

O projeto que eu saio do chão.

Aprender é você ter o conhecimento

De saber o que fazer para continuar

Estudando sempre com a ciência De querer sempre mais.

Autor: Estudante 30 Equipe: "Subtração" $5^{\circ}$ ano $B$ 
O QUE APRENDEMOS

Aprendi que...

Malba Tahan contava as histórias brincando com a Matemática.

Ele gostava muito de propor vários desafios matemáticos

Para ensinar as crianças.

Nós sempre poderíamos aprender bem Matemática

Com os conselhos de Malba Tahan.

Precisamos aprender a Matemática dia a dia Aprendendo desafios matemáticos.

Para aprender Matemática Precisamos de lápis, papel e borracha.

Autor: Estudante 31

Equipe: Adição.

$5^{\circ}$ ano $B$
MALBA TAHAN

MALBA TAHAN

Esse projeto

É sobre Malba Tahan

Tia Cecília nos ajuda

E tem muita ternura.

Tia Meily que nos ensina

É nossa miga

Malba Tahan

Gosta do parente da rã.

Temos várias tarefas

Que tem que ser completas

De portas abertas

Fazemos várias descobertas.

Autor: Estudante 32

Equipe: "As Fórmulas"

$5^{\circ}$ Ano B
Estou gostando de aprender Nas aulas de Malba Tahan

Que ele fez uma parceria

Com Monteiro Lobato.

Eles misturaram Matemática

Com a literatura infantil

De Monteiro Lobato.

Malba Tahan escreveu

Vários livros

Sendo o mais famoso

O Homem que calculava.

Autor: Estudante 33

Equipe: "Os Sábios da Matemática" $5^{\circ}$ Ano B

\section{TUDO O QUE APRENDI}

SOBRE MALBA TAHAN

Eu gostei muito de aprender sobre Malba Tahan

Pois ele escreveu muitas histórias legais

$\mathrm{E}$ a que eu mais gostei foi " $\mathrm{O}$ vendedor de conselhos".

Também gostei de saber

Que ele gostava de brincar com sapo

E de escrever histórias.

E Malba Tahan foi um autor famoso

E o outro livro que eu gosto muito

"O homem que calculava".

Autor: Estudante 34 Equipe: "Subtração" $5^{\circ}$ Ano B

\section{A HISTÓRIA DE MALBA} TAHAN

Um Projeto de amor Que não tem dor

Um Projeto de carinho

Que começou de mansinho.

A Tia Meily é legal

E também genial

Nós aprendemos brincando

E nos emocionando.

Autora: Estudante 35 Equipe: "Subtração" $5^{\circ}$ Ano $B$

\section{O ESCRITOR MALBA} TAHAN

Nada de complicar Vamos apenas calcular Assim pensava Malba Tahan

O homem da Matemática

Que adorava a prática.

Professor e educador

Um ótimo orientador

Foi ainda escritor e conferencista

Da Matemática foi um estilista.

Eu gostei de toda a aprendizagem

Júlio César de Melo e Souza

Deixou em mim uma bela paisagem

Da história da Matemática.

Autora: Estudante 36 Equipe: "Subtração" 


\section{MALBA TAHAN}

Meu Deus,

Português e Matemática Tudo de uma só vez!

Adição, subtração, divisão Subtração e atividades No que isso se acabou? Matemática!

Contos, histórias e várias coisas Que aprendi este mês No que isso se acabou? Português!

Matemática e Língua Portuguesa Várias coisas deste mundo No que isso se acabou? Conhecimento puro!

Autor: Estudante 37 Equipe: "Adição" $5^{\circ}$ Ano B

\section{MALBA TAHAN}

Com as aulas sobre Malba Tahan Aprendi sobre coisas árabes.

$$
\begin{gathered}
\text { E eu adorei todas as aulas } \\
\text { Da Tia Meily }
\end{gathered}
$$

Que me ensinaram Português e Matemática.

Autor: Estudante 38 Equipe: "As fórmulas" $5^{\circ}$ Ano B

\section{O QUE APRENDI SOBRE MALBA TAHAN ATÉ AGORA...}

Aprendi várias coisas de Malba Tahan

Uma muito legal

Ele gostava de sapos

E tinha dificuldades em Matemática Acredita?

Ele escreveu vários livros Um muito famoso foi "O homem que calculava"

Ele era um grade amigo de Monteiro Lobato

Aquele que criou o Sítio do Picapau Amarelo.

Malba Tahan foi o gênio da Matemática!

Autor: Estudante 39 Equipe: "Divisão" 


\section{A Matemática é como \\ uma das verdades eternas...}

É preciso, ainda, não esquecer que a Matemática, além do objetivo de resolver problemas, calcular áreas e medir volumes, tem finalidades $m$ uito mais elevadas. Por ter alto valor no desenvolvimento da inteligência e do raciocinio, é a Matemática um dos caminhos mais seguros por onde podemos levar o homem a sentir o poder do pensamento, a mágica do espírito. A Matemática é, enfim, uma das verdades eternas e, como tal, produz a elevação do espírito - a mesma elevação que sentimos ao contemplar os grandes espetáculos da Natureza, através dos quais sentimos a presença de Deus, Eterno e Onipotente!

Malba Tahan, 1961.

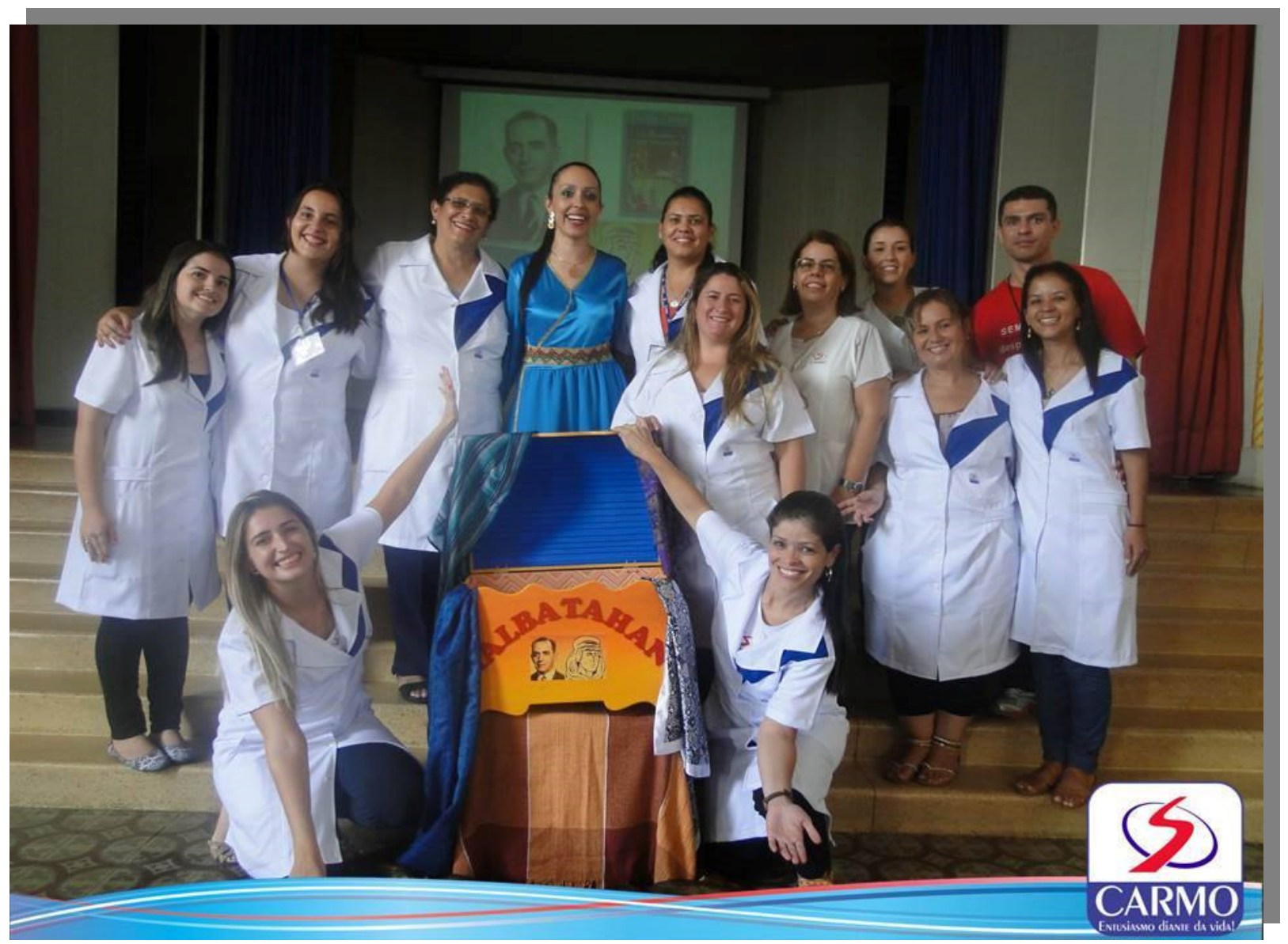

Equipe Educativa de 2015 - EFI - INSC. 
ANEXO U

Fotos da Exposição Malbatahânica

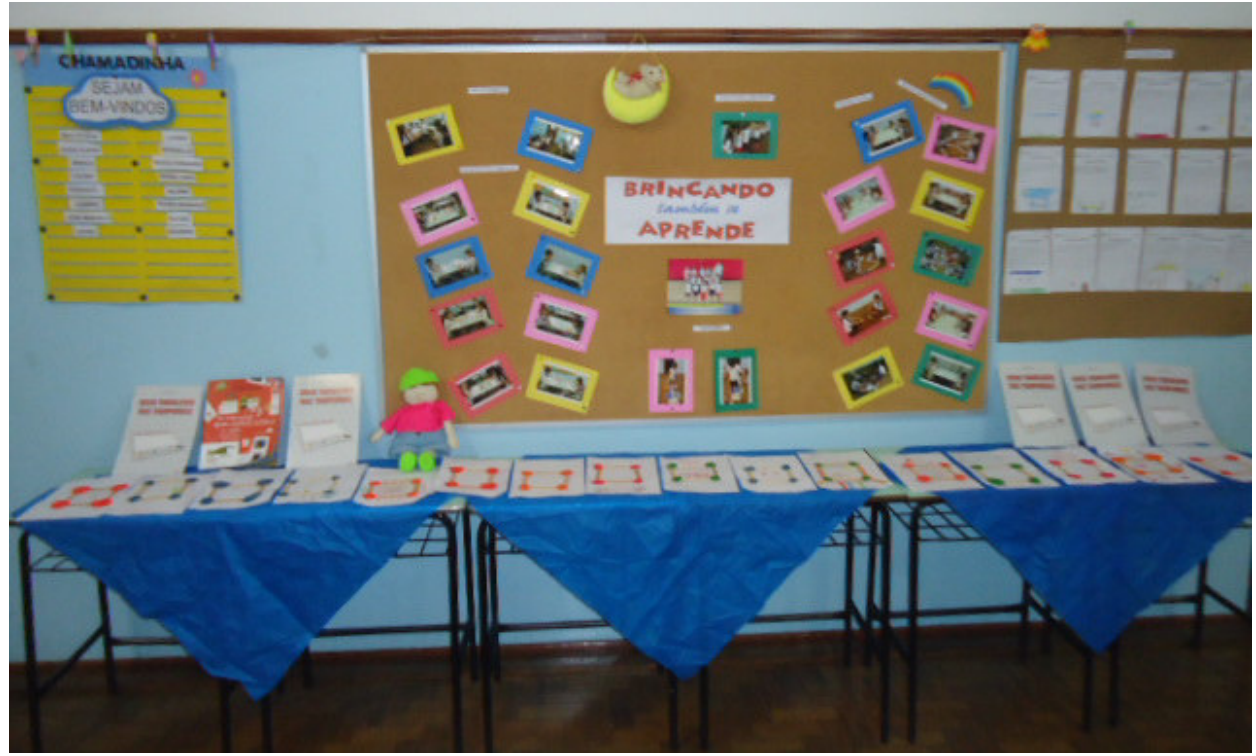

Exposição Malbatahânica da turma do $1^{\circ}$ Ano.

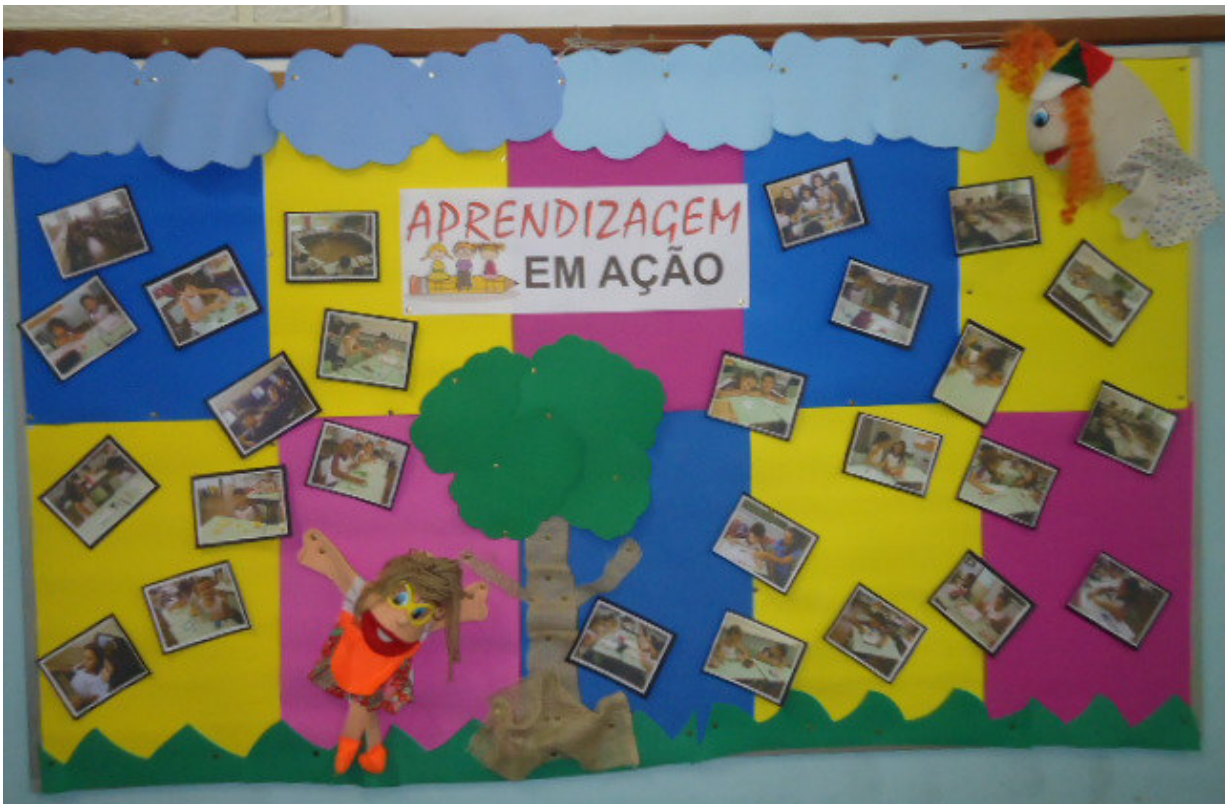

Painel com fotos organizado para a Exposição Malbatahânica ( $2^{\circ}$ Ano). 


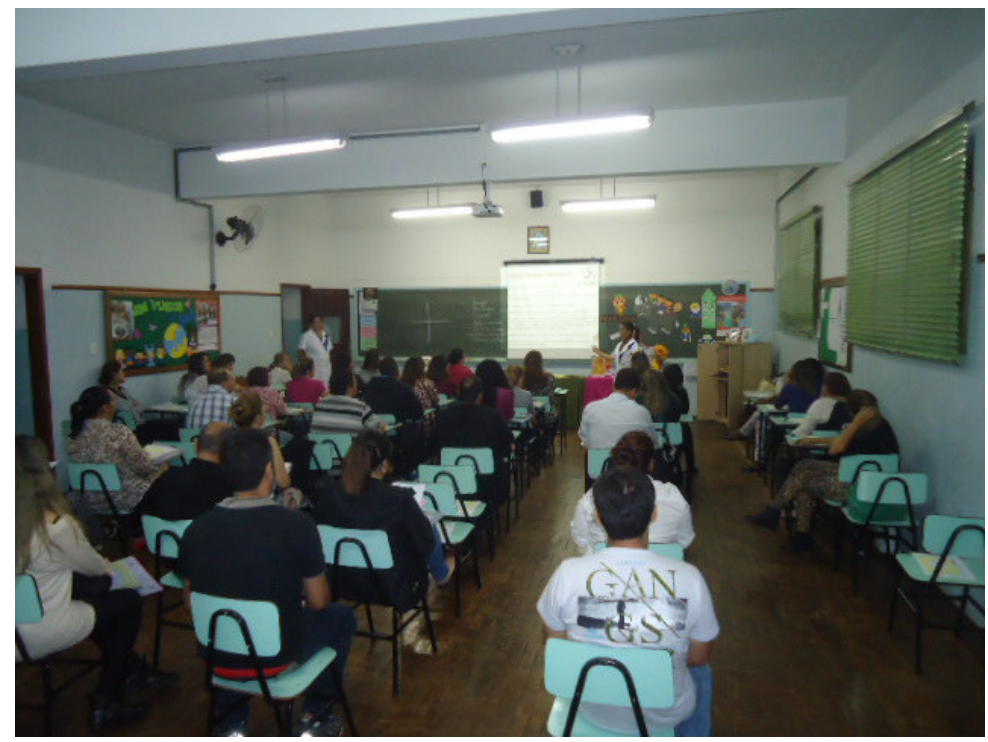

Apresentação das atividades matemáticas interdisciplinares realizadas com os estudantes dos $5^{\text {os }}$ Anos para os pais/responsáveis.

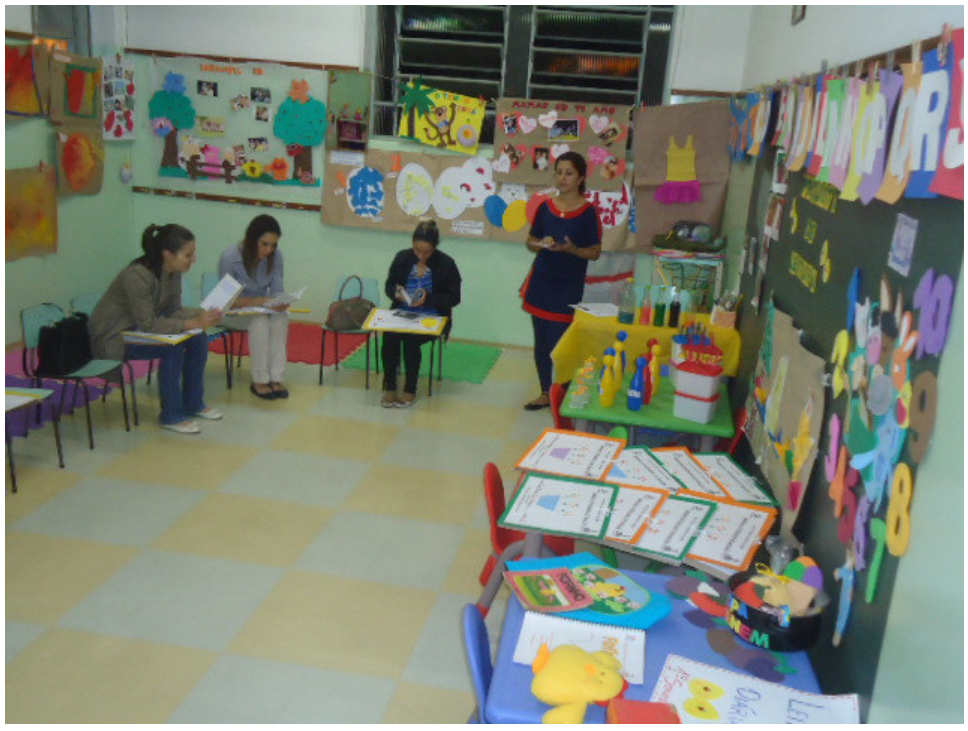

Reunião de Pais do Infantil I e exposição dos trabalhos matemáticos interdisciplinares desenvolvidos.

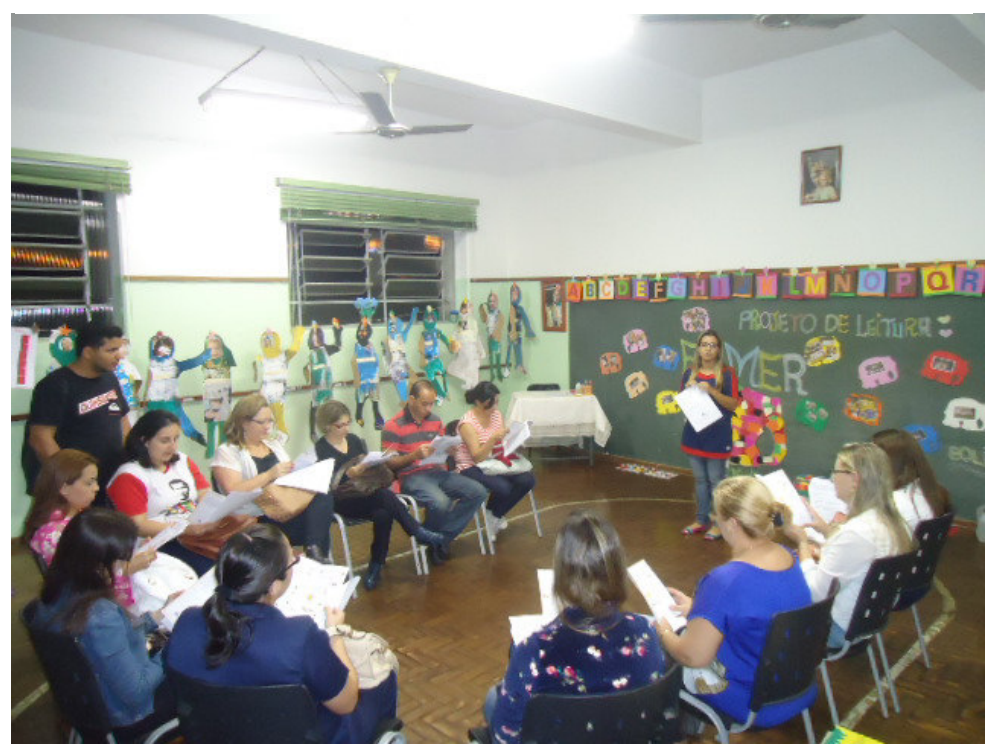

Professora com os pais dos estudantes do Infantil I durante a Exposição Malbatahânica e Reunião de Pais. 


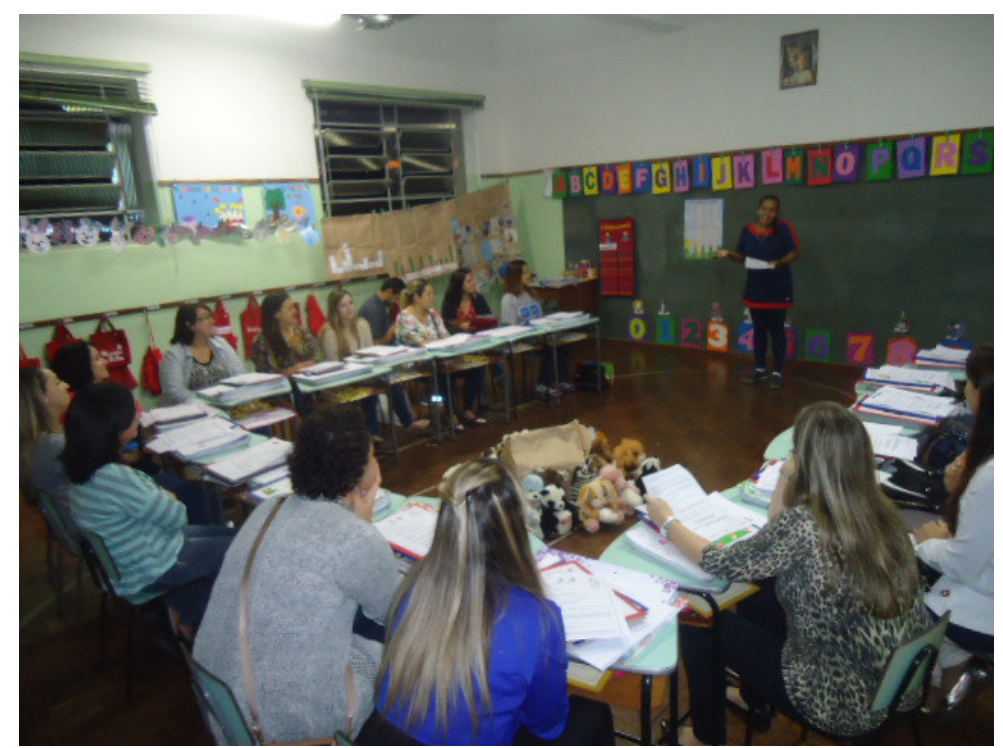

Pais atentos durante a apresentação das atividades matemáticas interdisciplinares (Infantil II).

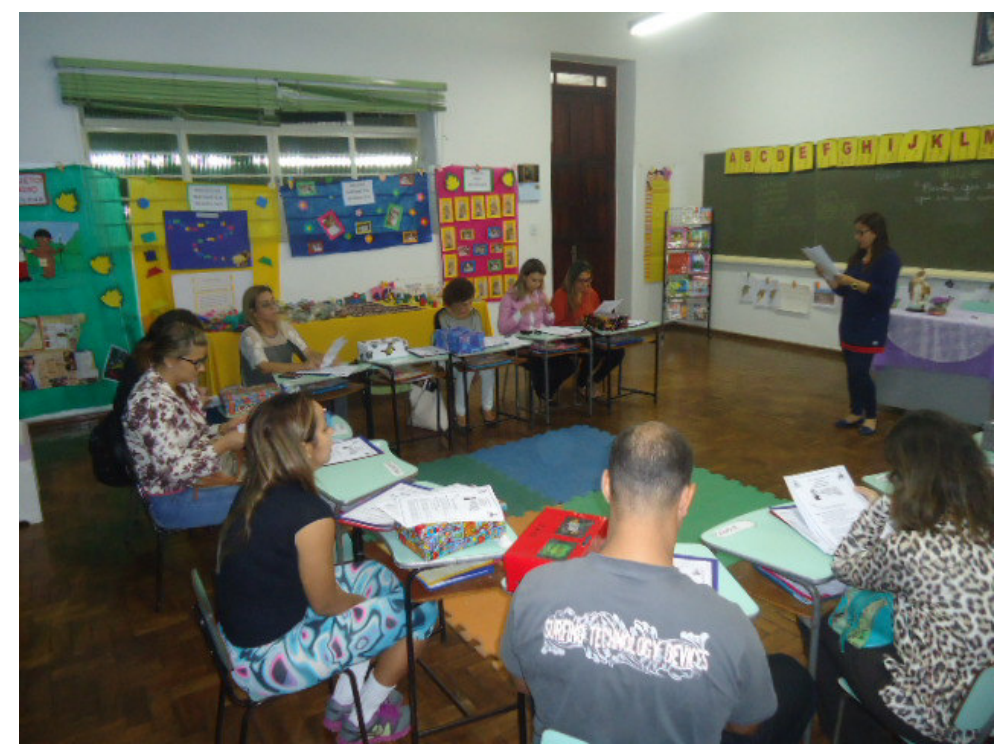

Professora e os pais dos estudantes do Infantil III durante a Reunião de Pais e Exposição Malbatahânica. 